UNIVERSIDADE DE SÃO PAULO

INSTITUTO DE FÍSICA

\title{
DIFUSÃO ANÔMALA DE MICROESFERAS EM ESTRUTURAS COMPLEXAS
}

\author{
MARIANA SACRINI AYRES FERRAZ
}

Orientador: Prof. Dr. Adriano Mesquita Alencar

\author{
Tese apresentada ao Instituto de Física \\ da Universidade de São Paulo para a \\ obtenção do título de Doutor em Ciências
}

\section{Banca Examinadora:}

Prof. Dr. Adriano Mesquita Alencar (IFUSP)

Prof. Dr. Madras Viswanathan Gandhi Mohan (UFRN)

Dr. Vinícius Bassaneze (Incor/FMUSP)

Profa. Maria Cecília Barbosa da Silveira Salvadori (IFUSP)

Prof. Dr. Mario José de Oliveira (IFUSP)

SÃO PAULO

2015 
FICHA CATALOGRÁFICA

Preparada pelo Serviço de Biblioteca e Informação do Instituto de Física da Universidade de São Paulo

\section{Ferraz, Mariana Sacrini Ayres}

Difusão anômala de microesferas em estruturas complexas. São Paulo, 2015.

Tese (Doutorado) - Universidade de São Paulo. Instituto de Física. Depto. Física Geral.

Orientador: Prof. Dr. Adriano Mesquita Alencar.

Área de Concentração: Física Geral

Unitermos: 1. Difusão; 2. Células; 3. Reologia. 
Dedico essa tese à minha família e aos meus amigos. 


\section{Agradecimentos}

Agradeço primeiramente ao meu orientador Adriano Mesquita Alencar. Além de inicialmente ter me aceitado como aluna de doutorado, esteve sempre presente, disposto a qualquer ajuda necessária. Um grande exemplo a ser seguido, cujos ensinamentos me acompanharão por toda minha vida acadêmica. Mais do que um orientador, um grande amigo que será levado por toda a vida.

Agradeço a todos do grupo e participantes do LabM ${ }^{2}$. Especialmente Alexandre, Diana, Wagner, Mac Gayver, Mariana Menegon, Matheus, Marcel, Juan, Fábio, Andrea, Lígia e Edi. Agradeço especialmente a Diana e Márcia, pelas experiências divididas no laboratório; ao Alexandre e à Mariana, meus queridos companheiros de sala e grandes amigos; ao Marcel por toda ajuda e amizade; Wagner pela amizade e muitos cafés. Agradeço a todos pela amizade e companheirismo.

Agradeço aos pesquisadores do InCor que nos forneceram materiais e células de músculo cardíaco para esse trabalho: Élida Neri, Vinícius Bassaneze e Prof. J. E. Krieger. Agradeço especialmente ao Vinícius, pela atenção e discussões, e também por ter me acompanhado em diversos experimentos.

Agradeço ao Ricardo Menegasso pela ajuda no desenvolvimento da instrumentação eletrônica, indispensável para a finalização desse trabalho. Sem essa ajuda, não teríamos os resultados 
encontrados aqui.

Agradeço à Andrea Fonseca da Cruz pelo desenvolvimento do aquecedor para a incubadora do microscópio. Essencial para completar o aparato experimental necessário para esse trabalho.

Agradeço ao Marcelino e ao Marcelo, por toda discussão e ajuda no desenvolvimento de aparatos essencias para esse trabalho. Sempre dispostos a ajudar e de ótimo bom humor.

Agradeço ao Valdir, à Fátima, à Dirce e à Silvana, por todo o suporte dado a mim e ao grupo ao longo desses anos de trabalho.

Agradeço ao Prof. J. J. Fredberg por ter me aceitado para o estágio sanduíche. E ao Dr. Chan Y. Park que me acompanhou em todo o estágio e ainda continua a colaborar com o nosso grupo.

Agradeço à minha família, meu pai Erlan, minha mãe Belarmina, meus irmãos Maurício, Marcelo, Matheus e Marcus, minhas cunhadas Ane, Luciane e Andrea, minhas sobrinhas Aileen e Yasmin, e também tia Flora, tia Goreti, Grazielle e Rogério. Sem o apoio e suporte de todos vocês, não chegaria onde estou hoje. Agradeço especialmente à minha mãe por estar sempre presente e me ajudar em todos os momentos.

Agradeço às agências de fomento CNPq, CAPES e FAPESP. Responsáveis pela minha bolsa de doutorado, bolsa do estágio sanduíche, e pelos financiamentos dos projetos de pesquisa do $\mathrm{LabM}^{2}$.

Obrigada a todos. 


\section{Abstract}

This is a theoretical and experimental work in which basic principles of statistical mechanics are used to understand the dynamics of micro and nano spheres attached directly or indirectly to living adherent cells, with the aim of the mechanical characterization of them. Among these basic principles, mainly concepts related to diffusion are included. In classical diffusion, there is a linear dependence of the mean squared displacement in time $\left\langle\Delta r^{2}(\Delta t)\right\rangle \propto \Delta T$. Otherwise, when $\left\langle\Delta r^{2}(\Delta t)\right\rangle \propto \Delta t^{\beta}$ and $\beta \neq 1$, there is what is called anomalous diffusion. If $\beta>$ 1 , the process is superdiffusive, and $\beta<1$, subdiffusive. To study the mechanical behavior of complex systems, micro and nanospheres can be used as analysis elements. These spheres are arranged in the material to be studied, and from observation of the dynamics is possible to characterize the leading process of this dynamic and therefore infer physical properties of the material. In this work, particle tracking techniques, for microscopic and nanoscopic spheres, are applied to study dynamic properties of cells, especially diffusivity, remodeling of the cell structure and force fields. For that we used two experimental techniques of tracking of micro and nanospheres, and phenomenological and statistical mechanics models. These dynamic properties have a great similarity to soft glassy materials. In this context, certain cellular functions such as division, contraction, diffusion, require that cells present fluidity similarly to a liquid, while for other functions, such as keeping the cellular structure, they should have a stiffer appearance. These characteristics resemble a glassy material, where disorder and metastability are underlying characteristics of their mechanical functions. The experimental results presented here show this metastability as anomalies and temporal correlations of the various data collected. We also explain the experimental data found in terms of metabolic activity and the active remodeling of the cytoskeleton. Also data obtained for heart muscle in full pulsatile activity is showed. The results obtained have direct applications in basic and clinical research. 


\section{Resumo}

Esse é um trabalho teórico e experimental em que princípios básicos de mecânica estatística são utilizados para entender a dinâmica de micro e nano esferas acopladas direta e indiretamente a células aderentes vivas, objetivando a caracterização mecânica das mesmas. Dentre esses princípios básicos estão inclusos, principalmente, conceitos relacionados à difusão. Na difusão clássica, tem-se uma dependência linear do deslocamento quadrático médio com o tempo, $\left\langle\Delta r^{2}(\Delta t)\right\rangle \propto \Delta t$. Caso contrário, quando $\left\langle\Delta r^{2}(\Delta t)\right\rangle \propto \Delta t^{\beta}$ e $\beta \neq 1$, tem-se o que se chama de difusão anômala. Caso $\beta>1$, o processo é superdifusivo, e se $\beta<1$, subdifusivo. Para se estudar o comportamento mecânico de sistemas complexos pode-se usar micro e nanoesferas como elementos de análise. Essas esferas são dispostas no material a ser estudado, e observando a sua dinâmica é possível caracterizar o processo que conduziu essa dinâmica e consequentemente inferir propriedades físicas do material. Nesse trabalho aplicam-se técnicas de rastreamento de partículas, microscópicas e nanoscópicas, para estudar propriedades dinâmica de células, especialmente difusibilidade, remodelação da estrutura celular e campos de força. Para isso foram utilizadas duas técnicas experimentais de rastreamento de micro e nanoesferas e modelos fenomenológicos e de mecânica estatística. Essas propriedades dinâmicas tem uma grande semelhança com materiais vítreos moles. Nesse contexto, certas funções celulares, como divisão, contração, difusão, requerem que as células apresentem fluidez similarmente a um líquido, enquanto que para outras funções, como manter a sua estrutura celular, elas devam ter uma aparência mais rígida. Essas características assemelham-se a um material vítreo, onde desordem e metastabilidade são características subjacentes de suas funções mecânicas. Os resultados experimentais apresentados aqui evidenciam essa metaestabilidade na forma de anomalias e correlações temporais dos vários dados coletados. Também explicamos os dados experimentais encontrados em termos das atividades metabólicas e a remodelação ativa do citoesqueleto. Mostra-se também os dados obtidos para músculo cardíaco em plena atividade pulsátil. Os resultados aqui obtidos têm aplicações diretas em pesquisa básica e clínica. 


\section{Sumário}

$\begin{array}{ll}\text { Agradecimentos } & \text { v }\end{array}$

Abstract $\quad$ vii

$\begin{array}{ll}\text { Resumo } & \text { ix }\end{array}$

1 Introdução $\quad 3$

1.1 Matéria Mole e Movimento Browniano . . . . . . . . . . . . . . 6

1.1.1 Movimento Browniano . . . . . . . . . . . . . . . . 6

1.1.2 Deslocamento Quadrático Médio . . . . . . . . . . . . . . 8

1.2 Reologia . . . . . . . . . . . . . . . . . . . 9 9

1.2.1 Matéria e Tensão por Cisalhamento . . . . . . . . . . . . . 11

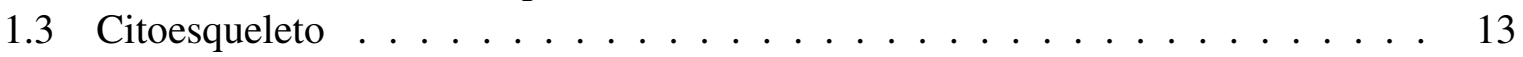

1.4 Microrreologia . . . . . . . . . . . . . . . . . 16

1.4.1 Citometria Óptica de Torção Magnética (OMTC) . . . . . . . . . . . . 17

1.4.2 Difusão Anômala e a Relação de Stokes-Einstein Generalizada . . . . . 18

1.5 A Teoria dos Materiais Vítreos Moles . . . . . . . . . . . . . . . . . 20

1.6 Migração Celular . . . . . . . . . . . . . . . . . . . . . . . . . . . . . . . . . . . . . .

1.7 Estrutura do Texto . . . . . . . . . . . . . . . . 27

2 Objetivos $\quad 29$

3 Difusão Anômala e a Dinâmica do Citoesqueleto 31

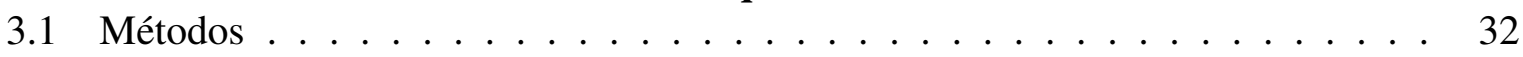

3.2 Resultados e Discussão . . . . . . . . . . . . . . . . . . . 35

4 A Dinâmica do Citoesqueleto e Abalos Sísmicos 47

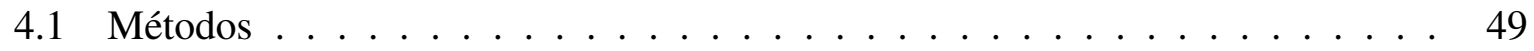

4.2 Resultados e Discussão . . . . . . . . . . . . . . . . . . . 52

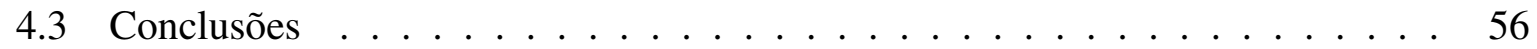

5 Análise Estatística para Counting Data 59

5.1 Métodos . . . . . . . . . . . . . . . . . . . . 62

5.2 Resultados e Discussão . . . . . . . . . . . . . . . . . . . . 62

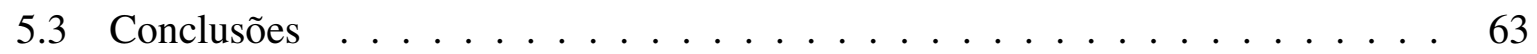


6 Difusão Anômala Evidenciada a Altas Frequências 65

6.1 Métodos . . . . . . . . . . . . . . . . . . . 66

6.2 Resultados e Discussão . . . . . . . . . . . . . . . . . . . . . . . . . . 69

6.3 Conclusões . . . . . . . . . . . . . . . . . . . . . 73

7 Movimento Browniano e Modelagem da Dinâmica do Citoesqueleto 75

7.1 Movimento Browniano . . . . . . . . . . . . . . . . . . . . . . . 75

7.2 Movimento Browniano e Sistemas Massa-Mola . . . . . . . . . . . . . . . 81

7.2.1 Sistemas Massa-Mola . . . . . . . . . . . . . . . . . . . 82

7.2.1.1 Sistema Mola-Massa-Mola . . . . . . . . . . . . 82

7.2.1.2 Sistema Massa-Mola em Paralelo . . . . . . . . . . . . 83

7.2.2 Movimento Browniano Superamortecido em um Poço de Potencial Tipo Mola . . . . . . . . . . . . . . . . . . . . 84

7.2.2.1 Simulação Numérica $\ldots \ldots$. . . . . . . . . . . . 88

7.3 Modelagem do Citoesqueleto . . . . . . . . . . . . . . . . . . . . . . 89

7.3.1 Parâmetros Básicos para a Modelagem _. . . . . . . . . . . . . 90

7.3.2 Difusão em um Potencial Tipo Mola . . . . . . . . . . . . . . . . . 92

7.3.3 Difusão em um Potencial Tipo Mola Caminhante . . . . . . . . . . . 92

7.4 Modelo de Blocos Deslizantes _ . . . . . . . . . . . . . . . . . . . . 95

7.4.1 Modelagem do Citoesqueleto com Blocos Deslizantes . . . . . . . . . 98

8 Outros Desenvolvimentos 103

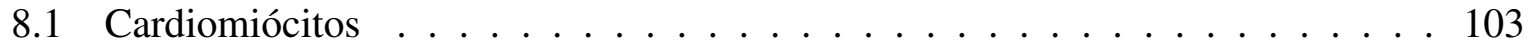

8.1 .1 Métodos . . . . . . . . . . . . . . . . . . . . . . . . . 104

8.1.2 Resultados Preliminares e Discussão . . . . . . . . . . . . . . . 106

8.2 Compressão Celular . . . . . . . . . . . . . . . . . . . . . . . . 109

8.2 .1 Métodos . . . . . . . . . . . . . . . . . . . 113

8.2.2 Resultados Preliminares e Discussão . . . . . . . . . . . . . . . . . 119

8.2.2.1 Modelo Teórico . . . . . . . . . . . . . . . . . 119

8.2.2.2 Calibração do Aparato com a Membrana . . . . . . . . . 120

8.2.2.3 Experimentos com células . . . . . . . . . . 121

9 Conclusões $\quad 125$

A Abordagem de Langevin Ao Movimento Browniano 129

B Relação de Stokes-Einstein Generalizada 137

B.1 Aproximação de Mason . . . . . . . . . . . . . . . . . . . . . . . . . . 140

$\begin{array}{ll}\text { C Teoria dos Materias Vítreos Moles } & 143\end{array}$

D Cultura Celular e Protocolo Experimental para Difusão Anômala e OMTC 147

D.1 Meio de Cultura Celular . . . . . . . . . . . . . . . . . . . . . . . . . . 147

D.2 Protocolo de Subcultivo e Manutenção de Células em Cultura Permanente . . . 148 
D.2.1 Protocolo Prévio . . . . . . . . . . . . . . . . . . . . 149

D.2.2 Protocolo de Subcultivo e Manutenção de Células em Cultura Permanente149

D.3 Mudança de Meio de Cultura . . . . . . . . . . . . . . . . . . . . . 151

D.3.1 Concentração celular . . . . . . . . . . . . . . . . 153

D.4 Descongelamento de Células em Ampolas . . . . . . . . . . . . . . . . . 155

D.5 Preparo para OMTC ou Difusão Anômala . . . . . . . . . . . . . . . . . . 155

D.5.1 Revestimento de 96 poços com Colágeno . . . . . . . . . . . . . 157

D.5.2 Revestimento das esferas com o peptídeo RGD . . . . . . . . . . . 158

D.5.3 Cultivo de Células em 96 poços . . . . . . . . . . . . . . . 160

D.5.4 Adesão das Esferas nas Células . . . . . . . . . . . . . . . . . . 161

$\begin{array}{lll}\text { E O software da OMTC } & 163\end{array}$

$\begin{array}{llr}\text { F } & \text { Microesferas } & 169\end{array}$

G Calibração das Câmeras $\quad 171$

H Método de Euler-Maruyama para Equações Diferenciais Estocásticas 173

$\begin{array}{ll}\text { I Atividades Acadêmicas } & 175\end{array}$

$\begin{array}{ll}\text { Referências Bibliográficas } & 178\end{array}$ 


\section{Lista de Figuras}

1.1-1 Imagens referentes ao cálculo do MSD a partir de um MB $\ldots \ldots \ldots$

1.1-2 Exemplos de movimentos e seus respectivos MSDs. . . . . . . . . . . . 10

1.2-3 Definições para o cisalhamento de um material. Fluido a um cisalhamento constante: $v$ é a velocidade da placa superior em relação a inferior e $d$ é a espessura da camada de fluido. . . . . . . . . . . . . . . . 11

1.3-4 Os três tipos de componentes do CSK . . . . . . . . . . . . . . . . . 14

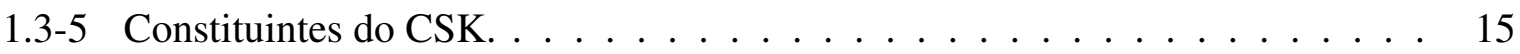

1.4-6 Microesferas e esquema da citometria óptica de torsão magnética. . . . . 17

1.4-7 Comportamento do módulo $\tilde{G}$ para líquidos e sólidos. . . . . . . . . . . . 18

1.5-8 Gráfico do deslocamento quadrático médio MSD por $\Delta t$ das microesferas sob variadas condições. . . . . . . . . . . . . . . . . . 21

1.6-9 Mecanismo conhecido como cabo de guerra. . . . . . . . . . . . . 23

1.6-10 Tensão calculada a partir de uma monocamada celular. . . . . . . . . . . . . 24

1.6-11 Representação dos estresses em uma monocamada celular. . . . . . . . . . . 24

1.6-12 Comportamento migratório de células MDCK em uma monocamada confluente. 25

1.6-13 Diagrama de fase jamming hipotético para uma monocamada celular. . . . . . 26

3.1-1 Aparato experimental. Microscópio invertido com câmera acoplada ligadas ao computador. Em destaque, local onde se encaixa os poços. . . . . . . . . . 34

3.2-2 Experimentos com esferas ferrimagnéticas. . . . . . . . . . . 36

3.2-3 Experimentos com esferas de látex. . . . . . . . . . . . . . . . . 37 
$3.2-4$ Ajuste do MSD. . . . . . . . . . . . . . . . . 38

3.2-5 Movimentação de uma microesfera ligada ao CSK. . . . . . . . . . . . . 39

3.2-6 Histogramas dos $Z$ s referente ao tempo dos deslocamentos posteriores e anteriores a um salto anômalo onde $|Z| \geq 3 . \ldots . . . . . . . . . . .40$

3.2-7 Modelando o movimento das esferas através de duas Gaussianas. . . . . . . . 42

3.2-8 Imagens das microesferas de látex e ferrimagnéticas. . . . . . . . . . . . 43

4.1-1 Dinâmica das microesferas anexadas em célula do músculo liso de vias aéreas humanas. .............................. 50

4.2-2 Número cumulativo de saltos maiores que um limiar para um dado trigger

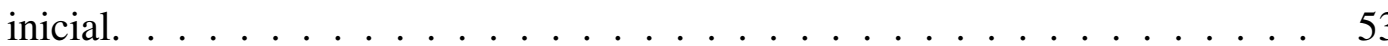

4.2-3 Dado um grande evento, probabilidade de ter pelo menos um salto maior que um limiar. . . . . . . . . . . . . . . . . . . . 54

4.2-4 Densidades de probabilidades espaciais para células e simulações. . . . . . . 55

5.2-1 Dados experimentais para a magnitude dos deslocamentos do Cap. 4 ajustados com regressão linear generalizada com erros dados por duas distribuições: Poisson e Gaussiana. . . . . . . . . . . . . . . . . . . . . 63

5.2-2 Densidade de Probabilidade dos dados mostrados na Fig. 5.2-1, pontos, ajustados com stable distribution, linha contínua. . . . . . . . . . . . . . . . . . . 64

6.1-1 Montagem experimental para aquisição em altas frequências no LabM ${ }^{2}$ . . 67

6.1-2 Microcontrolador ATmega328 feito para controle externo do trigger da câmera. 69

6.2-3 MSD médio (a) e inclinação (b) para experimentos com magnificação de $10 \times . \quad 70$

6.2-4 MSD médio (a) e inclinação (b) para experimentos com magnificação de $20 \times . \quad 70$

6.2-5 Histogramas dos Z's. . . . . . . . . . . . . . . 71

6.2-6 Histogramas dos Z's. . . . . . . . . . . . . . . . 72 
6.2-7 Porcentagem de eventos anômalos referentes aos histogramas mostrados na Fig. 6.2-6. . . . . . . . . . . . . . . . . 72

7.1-1 Tipos de MB simulados para uma partícula. . . . . . . . . . . . 76

7.1-2 Deslocamentos quadráticos (MSD) de 20 trajetórias de MBs difusivos. . . . . 77

7.1-3 Movimento criado a partir dos três tipos apresentado na Fig.7.1-1 que simularia o movimento do CSK. . . . . . . . . . . . . . . . . . . . . 79

7.1-4 MB criado alternando-se entre períodos de confinamento e difusivo. . . . . . 80

7.1-5 Microesfera recoberta por RGD anexado ao citoesqueleto. . . . . . . . . . . 81

7.1-6 Esquema de uma microesfera na célula, onde as ligações com as fibras de estresse são representadas por molas. . . . . . . . . . . . . . . . . . . . . 81

7.2-7 Sistema mola-massa-mola, onde $x_{0}$ é posição de equilíbrio, $m$ é a massa e $k_{1}$ e $k_{2}$ são as constantes da mola. . . . . . . . . . . . . . . . . . . 82

7.2-8 Sistemas massa-mola. . . . . . . . . . . . . . . . . . 83

7.2-9 Resultado do MSD para a simulação do sistema massa-mola descrito na Seção 7.2.2. . . . . . . . . . . . . . . . . . . . . . . . 89

7.3-10 MSD calculado numericamente a partir dos parâmetros descritos na Seção 7.3.1. 93

7.3-11 MSD calculado numericamente. A linha pontilhada horizontal indica $R_{l}^{2}$, enquanto que as verticais indicam $\tau_{0}$ e $\tau_{1} \ldots \ldots \ldots$. . . . . . . . . . . . 94

7.3-12 Histograma dos $Z$ s referente a simulação. . . . . . . . . . . . . . . . 96

7.4-13 Modelo de bloco deslizante constituido de um único bloco de massa $m$ puxado sobre uma superfície por uma placa condutora com uma velocidade constante $v .96$

7.4-14 Gráficos das posições $y_{0}, y_{1}$ e $y$, e suas respectivas velocidades e acelerações da simulação feita das Eqs. 7.54 e $7.55 \ldots$. . . . . . . . . . . . . . 98

7.4-15 Gráficos obtidos da simulação com blocos deslizantes baseada nas Eqs. 7.56. . 99

7.4-16 Porcentagem de eventos anômalos onde $Z \geq 3$ para diferentes frequências de aquisição. . . . . . . . . . . . . . . . . . . . 100 
8.1-1 Esquema da técnica de TFM. . . . . . . . . . . . . . . . . . . . 106

8.1-2 Posição $r$ em pixel de uma microesfera aderida em um cardiomiócito do tipo WT. A linha em preto representa a movimentação antes do fármaco e a linha em azul depois do fármaco. . . . . . . . . . . . . . . . . . . . 107

8.1-3 Imagem em contrate de fase do cardiomiócito do tipo WT e suas trações referentes. . . . . . . . . . . . . . . . . . . . 108

8.1-4 Momento contrátil total de cardiomiócito do tipo WT utilizando a técnica de TFM com alta frequência de aquisição. . . . . . . . . . . . . . . . . 110

8.1-5 Densidades de probabilidades dos intervalos temporais entre os pulsos. . . . . 111

8.2-6 Caracterização da super-população experimental. . . . . . . . . . . . . . 112

8.2-7 Aparato para stretch equibiaxial. . . . . . . . . . . . . . . . . . . . . 114

8.2-8 Modelo teórico para predizer a magnitude do strain da membrana. . . . . . 116

8.2-9 Montagem experimental do Laboratory for Molecular and Integrative Cellular Dynamics - Harvard School of Public Health. . . . . . . . . . . . . . 119

8.2-10 Curvas teóricas obtidas para estiramento e compressão. . . . . . . . . . . . 120

8.2-11 Curvas de calibração do aparato com a membrana. . . . . . . . . . . . . . 121

8.2-12 MSDs obtidos durante o experimento de compressão em momentos diferentes. 122

8.2-13 Velocidades calculadas em diversos estágios do processo de compressão para

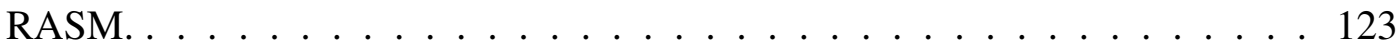

8.2-14 Vetores de deslocamento obtidos para o controle, imagem à esquerda, e após $5 \mathrm{~h}$ da compressão, imagem à direita. . . . . . . . . . . . . . . . 123

8.2-15 Velocidades calculadas em diversos estágios do processo de estiramento para MDCK. . . . . . . . . . . . . . . . . . . . 124

E.0-1 Foto de uma tela do software que controla o OMTC. . . . . . . . . . . . . 164

E.0-2 Gráficos das esferas geradas e suas trajetórias. . . . . . . . . . . . . 165

E.0-3 Cálculo do erro para a simulação computacional. . . . . . . . . . . . . . 166 


\section{Lista de Tabelas}

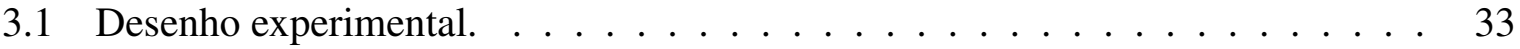

3.2 Parâmetros do ajuste de duas Gaussianas, como descrito no texto, dos histogramas mostrados nas Figs. 3.2-6 a, b e c. . . . . . . . . . . . . . . . 41

7.1 Valores de $k_{\mathrm{ef}} \mathrm{em} \mathrm{nN} / \mu \mathrm{m}$ encontrados para diversos valores totais de ligações e para todos os $l_{0}$ iguais a $5 \mu \mathrm{m}$ ou $25 \mu \mathrm{m}$, ou distribuídos uniformemente entre 5

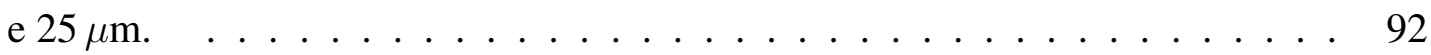

D.1 Tipos de meio de cultura para os tipos celulares utilizados neste projeto. . . . 147

F.1 Características das microesferas de látex. . . . . . . . . . . . . . . . . . 169

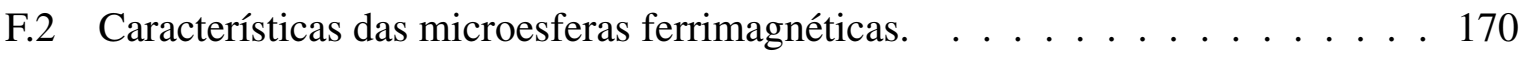

G.1 Tabela com os valores de calibração $\mu \mathrm{m} /$ pixel para a câmera Pike AVT. . . . . . 171

G.2 Tabela com os valores de calibração $\mu \mathrm{m} /$ pixel para a câmera Andor Neo sCMOS. 171 
LISTA DE TABELAS 


\section{Capítulo 1}

\section{Introdução}

Difusão anômala de microesfera em estruturas complexas vem atraindo o interesse de cientistas devido à possibilidade de sua utilização na obtenção de informação reológica em células vivas, em especial, células aderentes com uma estrutura esquelética, citoesqueleto (CSK) bem definida. O CSK é composto por um emaranhado de proteínas filamentosas, filamentos de actina, microtúbulos e filamentos intermediários, e é responsável por diversas funções nas células, como manter a forma e rigidez, gerar força, adesão, migração, transporte intracelular, dentre outras. Essa estrutura tem uma tensão e é altamente dinâmica, podendo se remodelar, encontrando-se em permanente estado de desmontagem (disassembly) e remontagem (reassembly) [1-4].

A dinâmica do CSK está envolvida então em processos cruciais para as células e pode ser um indicativo da integridade celular. Nesse contexto, a dinâmica do CSK pode ser alterada devido a patologias, ou disfunções celulares devido ao uso de fármacos, por exemplo, no caso da asma, uma doença que leva à constrição das vias aéreas, gerado por um enrijecimento das suas células de músculo liso [5,6]. Já em relação aos fármacos, diversos têm efeitos diretamente no CSK 


\section{Introdução}

como por exemplo: DBcAMP que diminui a contratilidade da célula, e Jasplakinolide que estabiliza a actina [7]. Assim, mudanças na dinâmica do CSK podem acarretar em problemas e disfunções celulares, levando ao mal funcionamento de órgãos e doenças. Desta maneira, o entendimento da dinâmica do CSK, tanto do ponto de vista metabólico quanto no mecânico, é de extrema importância para o entendimento dos processos celulares.

A dinâmica do CSK pode ser estudada por meio do movimento espontâneo de microesferas ligadas ao CSK [7], ou seja, difusão. A difusão é usualmente associada a movimento Browniano (MB). O MB foi observado primeiramente em 1828 por Robert Brown, e é o movimento estocástico de partículas suspensas em uma solução devido ao constante choque das moléculas constituintes do meio, sendo então um movimento livre guiado termicamente [8,9], e cuja distribuição dos deslocamentos é dada por uma distribuição Gaussiana. Por outro lado, no CSK, há evidências que a movimentação das microesferas não é gerada apenas por movimento térmico, mas também pelas atividades da célula, que está associada a liberação de energia associado ao trifosfato de adenosina (ATP), uma das moléculas geradoras de energia nas células. A hipótese então é que se a estrutura em que a microesfera está ligada se move, a microesfera também se move. Assim, o movimento da microesfera poderia ser visto como um sensor que revelaria o remodelamento do CSK [7].

Observando o remodelamento do CSK a partir de microesferas, pode-se observar que estas apresentam uma dinâmica intermitente, com períodos de salto e de aprisionamento. Este comportamento é análogo com o que se observa em materiais vítreos moles [7] (SGM), associando a célula a questões estudadas em física da matéria condensada. Observando também o histograma de seus deslocamentos normalizados pelo desvio padrão, $Z$, é observado um comportamento anômalo. Ou seja, acima de um determinado valor de $|Z|$, há uma quebra do comportamento Gaussiano, aparecendo uma cauda não Gaussiana nesse histograma [7]. Entender essa quebra e as características desse comportamento anômalo é de suma importância para se compreender 


\section{Introdução}

as propriedades mecânicas do CSK.

Diversas técnicas são utilizadas para se estudar as propriedades mecânicas do CSK, dentre elas pode-se citar citometria óptica de torção magnética (OMTC), pinças ópticas e magnéticas, sendo usadas em um ramo da mecânica dos meios contínuos chamado reologia. Mas a de interesse nesse trabalho é especificamente a técnica de difusão, tanto do ponto de vista experimental quanto teórico. Esta técnica é passiva, sem nenhuma interferência externa. O objetivo específico então desse trabalho é entender acerca da difusão e remodelamento do CSK, e também o que esse comportamento observado poderia mostrar sobre o CSK. Outro ponto que será explorado é a diferença existente entre células epiteliais e células de músculo liso que podem ser observadas pela difusão.

Assim, essa primeira parte envolveu a dinâmica difusiva no interior das células. Mas estas, in vivo, não estão isoladas, mas sim conectadas umas as outras formando os tecidos. Desta maneira, pode-se questionar como é a dinâmica dessas unidades interconectadas, e qual a relação com a dinâmica interna de cada unidade. Da mesma forma que as células vistas individualmente apresentam características de SGM, estas em monocamadas (células interconectadas em cultura) também apresentam características relacionadas a SGM e também a jamming [10-12]. Assim, o segundo passo dessa trabalho é avaliar uma monocamada celular tanto para células epiteliais como para células de músculo liso, especificamente em caso de compressão celular, e como elas estariam relacionadas com o hipótese jamming. A compressão celular é um caso específico de estresse que a célula poderia sofrer se estivesse em um tecido in vivo, e o processo no qual é mantido um número ideal de células em monocamadas in vitro, ou tecido in vivo, ainda não é totalmente entendido. Este trabalho viria também para tentar contribuir para esse entendimento. 


\section{Introdução}

\subsection{Matéria Mole e Movimento Browniano}

Matéria mole é um termo usado para matéria condensada que não pode ser classificada nem como líquido simples e nem como sólido cristalino, como por exemplo colas, tintas, soluções poliméricas, dentre outros. Segundo R. A. L. Jones [13], matérias mole, por mais diferentes que sejam, compartilham algumas características, como: a) escala de comprimento, que estaria entre tamanhos atômicos e escalas macroscópicos, por exemplo: partículas coloidais são tipicamente menores que um micrômetro; b) a importância de flutuações e movimento Browniano (MB), as estruturas são pequenas o suficiente, desta maneira o MB é significante; c) tendência a selfassembly, na matéria condensada, quando esta tende ao equilíbrio, o resultado é usualmente estruturas complexas que surgem espontaneamente. Desta maneira, a matéria mole não tem uma classificação tão definida, apresentando característica de ambos, líquidos e sólidos, sendo portanto viscoelástica. Essas características são estudadas por um ramo da mecânica chamado reologia, ver Seção 1.2.

\subsubsection{Movimento Browniano}

O movimento irregular de pequenas partículas imersas em uma solução foi originalmente observado em 1828 pelo botânico inglês Robert Brown. Ele notou que as partículas em suspensão adquiriam uma espécie de movimento errático que posteriormente ficaria popularmente conhecido pelo nome de Movimento Browniano (MB) [8,9]. As primeiras teorias sobre o MB foram publicadas independentemente por Albert Einstein em 1905 e por Marian Smoluchowski em 1906 [8]. Posteriormente, outros cientistas deram sua contribuição de forma a dar um novo tratamento às idéias publicadas por Einstein, como Paul Langevin e Adriaan Fokker. A abordagem de Langevin ao MB está descrita no Apêndice A. 


\section{Introdução}

Movimento Browniano são, então, movimentos estocásticos de pequenas partículas suspensas em uma solução, como por exemplo água ou ar, e são localizadas espacialmente pelo vetor $r(t)$. As moléculas constituintes do fluido golpeiam constantemente as partículas imersas, resultando num movimento caótico e não direcionado. Partindo de uma posição inicial $r_{0}=r_{0}\left(t_{0}\right)$ e dado um intervalo temporal $\Delta t$, a partícula se movimenta para uma nova posição $r_{1}=r\left(t_{0}+\Delta t\right)$ e $\Delta r_{1}=r_{1}-r_{0}$ pode ser definido como a diferença entre as duas posições. De uma forma geral, tem-se que $r_{i}=r\left(t_{0}+i \Delta t\right)$ e $\Delta r_{i}=r_{i}-r_{i-1}$. Pode-se então definir uma nova série de deslocamentos $\Delta r_{1}, \Delta r_{2}, \Delta r_{3}, \ldots, \Delta r_{N-1}$ para um dado $\Delta t$, onde $N$ é o número total de eventos, tal que a média desses deslocamentos ao quadrado define o deslocamento quadrático médio, Mean Squared Displacement (MSD) dado por: $\left\langle\Delta r^{2}(\Delta t)\right\rangle$, onde $\langle\ldots\rangle$ é a média em relação aos $i$ s. O MSD é caracterizado pelo coeficiente de difusão, $D$, que é a medida da velocidade da difusão. Para um MB tridimensional, esse coeficiente é dado por:

$$
D=\frac{\left\langle\Delta r(\Delta t)^{2}\right\rangle}{6 \Delta t}
$$

Para uma ou duas dimensões, $1 \mathcal{D}$ ou $2 \mathcal{D}$, a dependência com o tempo do MSD difere apenas por um fator numérico (para mais detalhes ver Apêndice A):

$$
\begin{aligned}
& \left\langle(\Delta x)^{2}\right\rangle=2 D \Delta t, \text { para } 1 \mathcal{D}, \\
& \left\langle(\Delta r)^{2}\right\rangle=4 D \Delta t, \text { para } 2 \mathcal{D} .
\end{aligned}
$$

Albert Einstein, por meio da semelhança entre soluções e suspensões diluídas [14], encontrou a relação entre o coeficiente de difusão e viscosidade, $\eta$. Assim, $D$ para uma partícula esférica de raio $a$ é dado por:

$$
D=\frac{k_{B} T}{6 \pi \eta a},
$$


Introdução
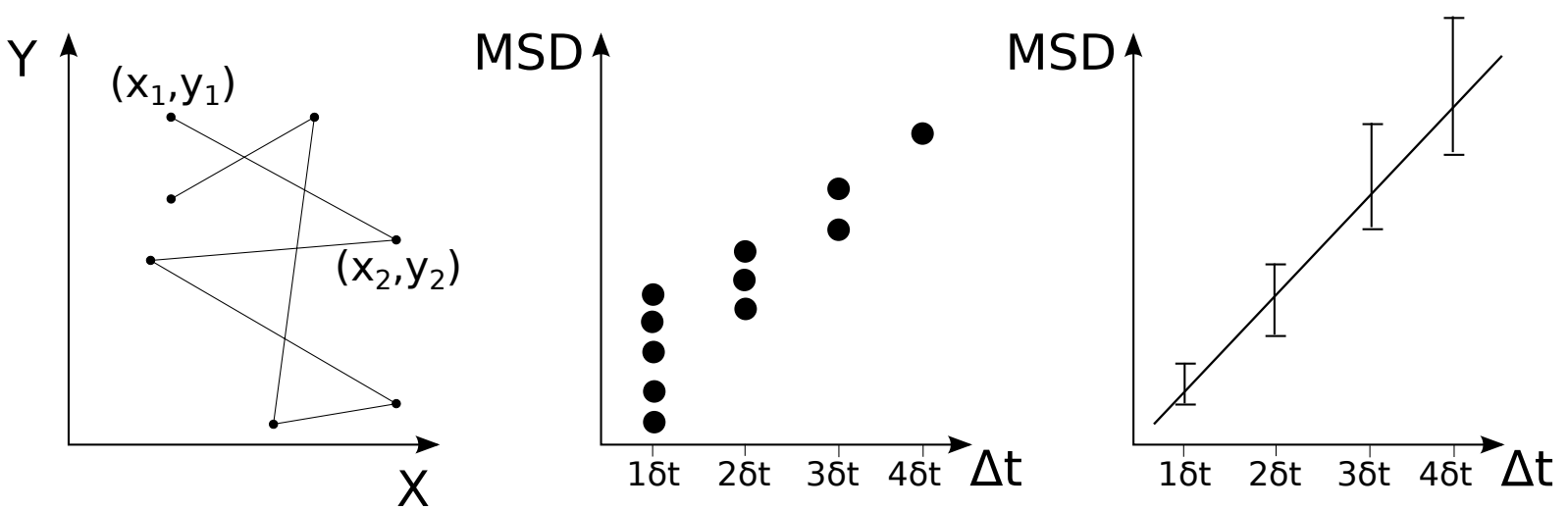

Figura 1.1-1. A primeira imagem à esquerda se refere a um MB típico e seus respectivos deslocamentos com o tempo. A imagem central mostra os cálculos referentes ao MSD de cada passo $\Delta t$, note que no início o número de MSDs é maior do que no final. A última imagem à direita mostra a média dos MSDs a cada $\Delta t$. Note que para pequenos $\Delta t$ s o erro é menor que para grandes $\Delta t$ s.

onde $k_{B}$ é a constante de Boltzmann e $T$ a temperatura.

O movimento Browniano é um exemplo clássico muito estudado de difusão, e de fácil visualização por meio de simulações, como mostrado no Capítulo 7.

\subsubsection{Deslocamento Quadrático Médio}

Considerando-se uma partícula em um movimento aleatório por um intervalo de tempo $T$, obtêm-se assim uma série temporal com $N$ posições da partícula. Para o cálculo do MSD, primeiramente são observadas as posições $x$ e $y$ separadas por uma série de intervalos temporais $\Delta t=\delta t, 2 \delta t, 3 \delta t, \ldots$, ver Fig.1.1-1, onde $\delta t$ é o menor intervalo da série temporal. O MSD também pode ser calculado com uma variação geométrica do tempo, como $\Delta t=$ $\delta t, 2 \delta t, 4 \delta t, 8 \delta t, \ldots$. Os deslocamentos, $\Delta x$ s e $\Delta y$ s, são então calculados para cada $\Delta t$ :

$$
x_{i}=x\left(t_{0}+i \Delta t\right) ; \Delta x_{i}(\Delta t)=x_{i}-x_{i-1} .
$$




\section{Introdução}

Os deslocamentos para o eixo y são análogos. O deslocamento quadrático $(\Delta r)^{2}$ é então a soma dos deslocamentos em respeito as diferentes dimensões, como mostrado na Fig. 1.1-1 central:

$$
\left(\Delta r_{i}(\Delta t)\right)^{2}=\left(\Delta x_{i}(\Delta t)\right)^{2}+\left(\Delta y_{i}(\Delta t)\right)^{2}
$$

Note que no início, como os $\Delta t$ s são pequenos, há um maior número de valores referentes ao MSD do que para grandes $\Delta t$ s. O MSD é então obtido como uma média de todos os passos correspondentes a cada $\Delta t$, Fig. 1.1-1:

$$
\left\langle(\Delta r(\Delta t))^{2}\right\rangle=\frac{1}{n}\left(\left(\Delta r_{1}(\Delta t)\right)^{2}+\left(\Delta r_{2}(\Delta t)\right)^{2}+\ldots\right)=\frac{1}{n} \sum_{i=1}^{n} \Delta r_{i}^{2}(\Delta t)
$$

onde $n$ é o inteiro da divisão $(N-1) \delta t / \Delta t$. Note também que o erro referente a pequenos $\Delta t$ s é menor que para grandes $\Delta t$ s, pois a medida que o $\Delta t$ vai aumentando, o $n$ vai diminuindo.

Este procedimento é aplicado para todos os $\Delta t$ s até obtermos o MSD para todos os múltiplos de $\delta$ s. Assim, fazendo um gráfico, o resultado é uma curva característica, Fig. 1.1-1 à direita. Se o movimento for difusivo, o MSD é proporcional a $\Delta t$. Pode-se também ter um comportamento anômalo, onde MSD $\propto \Delta t^{\beta}$, se $\beta<1$ tem-se um comportamento subdifusivo, e se $\beta>1$ um comportamento superdifusivo. O movimento pode ter características intermediárias, entre super e subdifuvivo, como difusão contendo algum tipo de obstáculos. Para um movimento restrito a uma área, o MSD tende a se estabilizar em um valor. Alguns exemplos estão mostrados na Fig. 1.1-2.

\subsection{Reologia}

A mecânica contínua se divide nos ramos de fluidos (fluidos Newtonianos e fluidos não-Newtonianos) e de sólidos (elasticidade e plasticidade), onde estudos referentes a reologia se en- 


\section{Introdução}
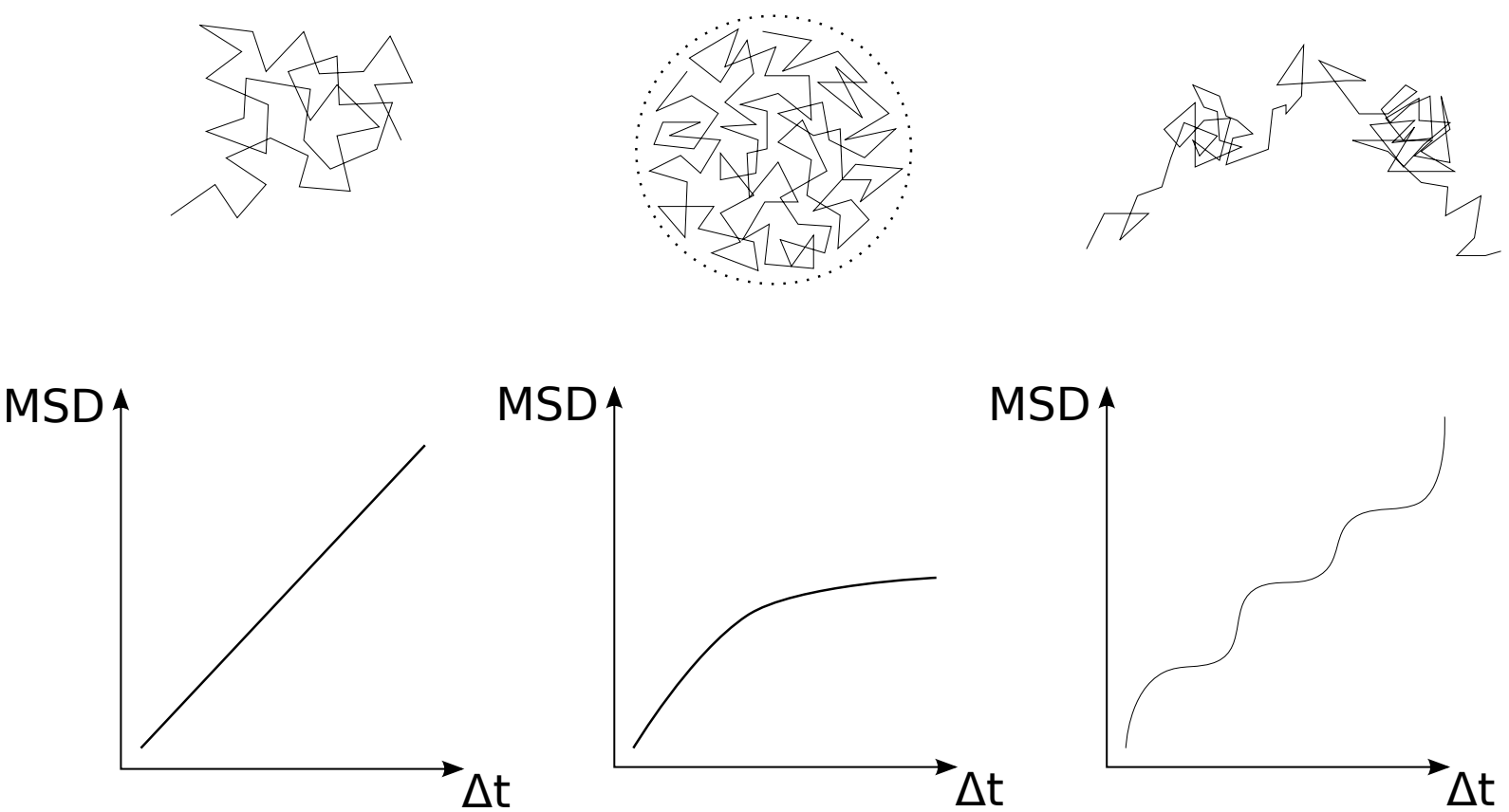

Figura 1.1-2. Exemplos de movimentos e seus respectivos MSDs. A imagem a esquerda mostra um MB difusivo; a imagem central mostra um MB confinado; e a imagem a direita mostra um movimento onde há algum tipo de barreira, alternando entre os casos das imagens anteriores.

contram entre plasticidade e fluidos não Newtonianos. O termo reologia foi criado por E. C. Bingham em 1928, e teve origem nas palavras gregas $\rho \epsilon^{\prime} \omega$ e $\lambda o^{\prime} \gamma o \sigma$ (pronunciado reos e logos) significando fluir e estudo respectivamente [15]. No começo esse termo era muito amplo abrangendo tópicos relacionados ao estudo da deformação e fluxo da matéria. Essa definição foi adotada um ano depois com a criação da Sociedade Americana de Reologia [15]. Com o passar do tempo, esse termo se tornou mais especializado e hoje é aplicado a fluidos que tem comportamento intermediário entre líquidos comuns e sólidos elásticos [15], ou seja, fluidos complexos.

Reologia então é o estudo do fluxo da matéria, inicialmente em estados líquidos, mas também de sólidos moles. As medidas reológicas podem dizer quão rígido ou mole é um material, e normalmente são aplicadas a substâncias que têm uma estrutura molecular complexa, como surfactantes, polímeros, e também, muitos alimentos e aditivos, fluidos corporais e materiais biológicos, como sangue [16]. 


\section{Introdução}
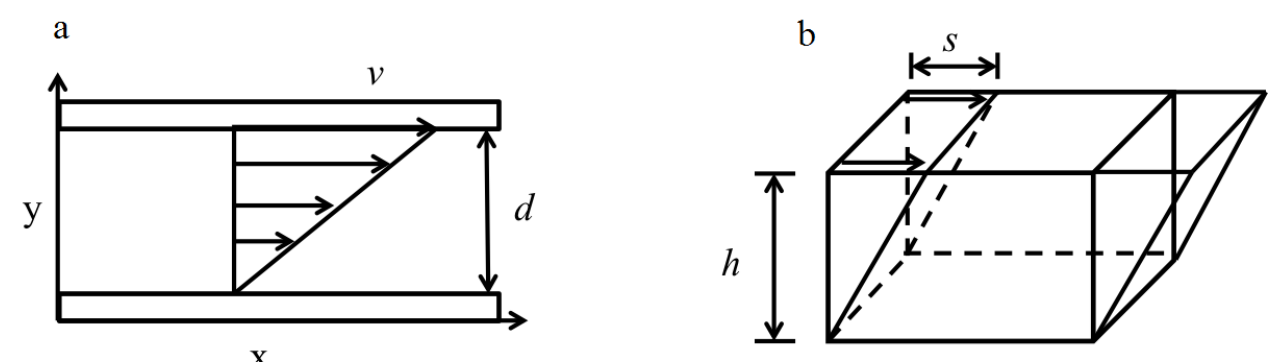

Figura 1.2-3. a) Definições para o cisalhamento de um material [13]. b) Fluido a um cisalhamento constante: $v$ é a velocidade da placa superior em relação a inferior e $d$ é a espessura da camada de fluido. Figura modificade de [15].

As estruturas internas dos materiais complexos levam a complicadas respostas mecânicas. O objetivo então de medidas reológicas é quantificar a viscoelasticidade sob diversas escalas de deformações e tempos, e relacionar essas propriedades com as estruturas em micro, meso e macro escalas do material.

\subsubsection{Matéria e Tensão por Cisalhamento}

A matéria pode ser encontrada em várias formas, sendo os casos extremos os sólidos elásticos descritos pela lei de Hooke (1678) e os fluidos viscosos, descritos pela lei de Newton (1687) [15].

A tensão por cisalhamento (shear stress) $\sigma$ é a força aplicada por área, ou seja, $\sigma=F / A$, e a deformação por cisalhamento (shear strain) $\gamma$ é dado por $\gamma=\Delta x / y$, ver Fig. 1.2-3 a. Para um sólido de Hooke uma tensão por cisalhamento aplicada produz uma deformação por cisalhamento em resposta, e a tensão por cisalhamento é proporcional a deformação por cisalhamento [13]. Assim, o comportamento de um sólido elástico perfeito é descrito pela lei de Hooke que é dada por:

$$
\sigma=G \gamma
$$




\section{Introdução}

onde a constante de proporcionalidade é $G$, o módulo de cisalhamento (shear modulus).

Como a tensão é dada em Pa no sistema SI ou em dyn $/ \mathrm{cm}^{2}$ no sistema CGS $(1 \mathrm{~Pa}=10$ dyn $/ \mathrm{cm}^{2}$ ) e a deformação é adimensional, $G$ é medido também em Pa ou dyn $/ \mathrm{cm}^{2}$.

A lei de Hooke diz que a deformação $\gamma$ é proporcional a tensão $\sigma$ aplicada, assim, quando a tensão é removida, a deformação cessa, e o corpo volta ao seu estado original, ou seja, ele mantém a memória de seu estado anterior [15]. Desta maneira pode-se dizer que um sólido elástico de Hooke representa o caso extremo onde este tem uma memória infinita. Também pode-se dizer que ele reponde instantaneamente a ação mecânica, não tendo tempo característico.

Em um líquido, uma tensão constante aplicada resultará em uma deformação dependente do tempo [13]. Para um líquido Newtoniano, a taxa da deformação será constante. Pode-se escrever:

$$
\sigma=\eta \dot{\gamma}
$$

onde $\sigma$ é a tensão aplicada, $\dot{\gamma}=v / d$ é o gradiente de velocidade, ou taxa de cisalhamento, ver Fig. 1.2-3 b, e $\eta$ é a viscosidade.

Assim pode-se dizer que para um líquido Newtoniano uma tensão cisalhante aplicada produz um fluxo com uma taxa de deformação constante, onde a constante de proporcionalidade é dada pela viscosidade.

Como $\dot{\gamma}$ é dada por $\mathrm{s}^{-1}$, a viscosidade é medida em Pa·s no sistema SI, também conhecido como Poiseuille, ou em P, Poise, no sistema CGS (1 Pa $\cdot \mathrm{s}=10 \mathrm{P})$.

O fluido Newtoniano responde instantaneamente ao cisalhamento, como no sólido de Hooke, porém, em contraste, não tem memória. Depois de uma tensão $\sigma$ ser aplicada por um tempo $t$, o fluido sofre uma deformação permanente e irreversível $\gamma=\sigma t / \eta$ e nunca retorna ao seu estado inicial depois da tensão ser removida [15]. 


\section{Introdução}

\subsection{Citoesqueleto}

O citoesqueleto celular é constituído por um complexo emaranhado de proteínas filamentosas que se estendem por todo citoplasma da célula. O CSK é responsável por manter a estrutura celular e sua rigidez e é responsável por diversas funções na célula, como adesão e migração, dentre outras $[1,2]$. É uma estrutura altamente dinâmica reorganizando-se a medida que a célula precise [3]. O CSK também exerce importantes funções no interior das células, que também é um ambiente bem dinâmico, como transporte de organelas, segregação do cromossomo, e separação das células animais durante a divisão celular [3]. Cada uma dessas funções são desempenhadas por seus componentes comentados a seguir.

Os principais componentes do CSK são os filamentos intermediários, microtúbulos e filamentos de actina, ver Figs. 1.3-4 e 1.3-5. Cada tipo é formado por subunidades protéicas diferentes, estas subunidades se juntam formando longos fios que se estendem por toda célula [3].

Filamentos intermediários (FIs) são formados por mais de 50 tipos diferentes de proteínas $[1,2]$. Eles formam uma estruturas em $\alpha$-hélice, que se enrolam formando os dímeros, Fig 1.3-5 b. Os dímeros se arranjam, e por ligações não-covalentes formando os tetrâmeros, que se conectam ponta-a-ponta formando os protofilamentos também por ligação não-covalente [3]. Estes, por sua vez, formam feixes em estruturas tipo corda contendo cerca de oito protofilamentos, com comprimento de aproximadamente $1 \mu \mathrm{m}$. OS FIs são muito estáveis e são formados sem hidrólise de ATP ou GTP, ou seja, sem necessidade de gasto de energia $[1,2]$.

Os FIs têm uma grande resistência à tração e sua principal função é permitir que as células suportem tensão mecânica gerada por um estiramento da célula [1]. Os FIs são os filamentos mais resistentes e duráveis dos três tipos de filamentos do CSK, se tratados com solução salina, são os únicos a permanecerem intactos [1-3]. 


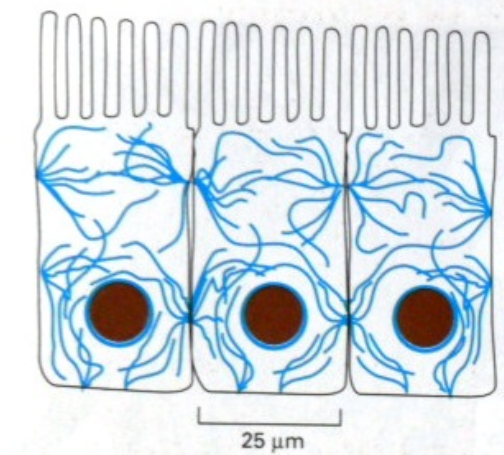

FILAMENTOS INTERMEDIÁRIOS
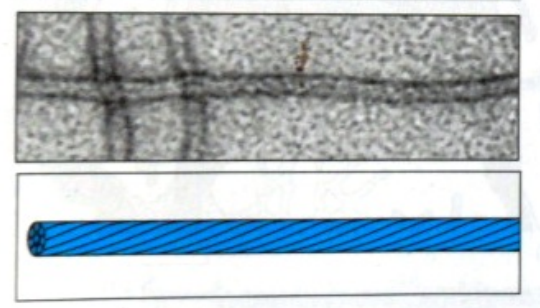

$25 \mathrm{~nm}$

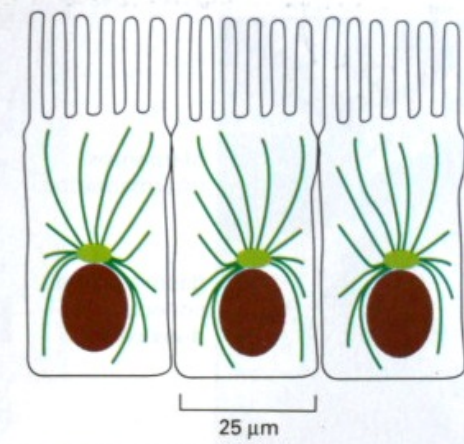

MICROTÚBULOS
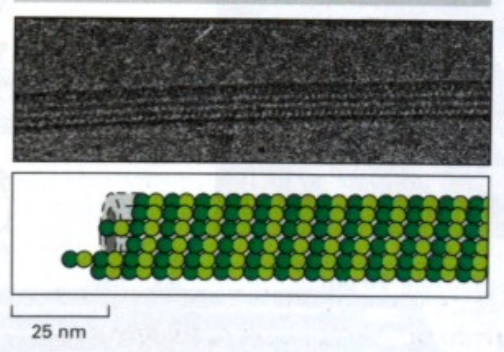

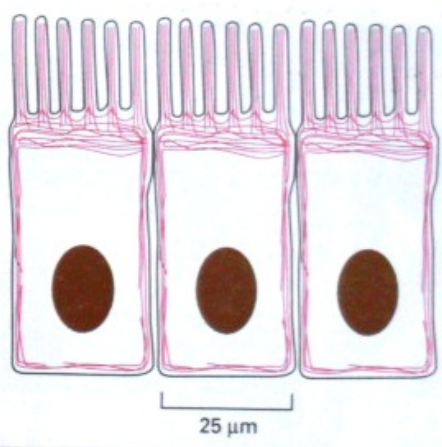

FILAMENTOS DE ACTINA
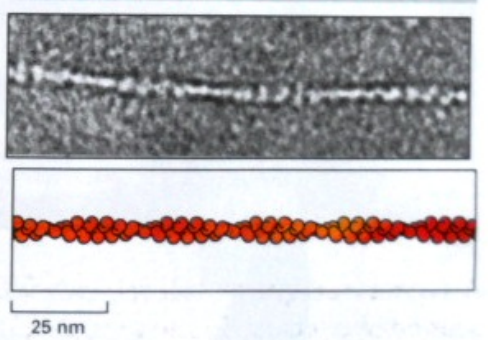

Figura 1.3-4. Os três tipos de componentes do CSK. As células desenhadas representam células epiteliais de revestimento do intestino. Figura modificada de [3].

Os FIs se estendem por todo citoplasma, e se ancoram à membrana plasmática nas junções célula-célula [3]. Também exercem função no núcleo, revestindo-o internamente e reforçandoo, sendo encontrado em todas células eucarióticas [3].

Microtúbulos (Ms) são constituídos por monômeros de $\alpha$-tubulina e $\beta$-tubulina, polimerizados num arranjo helicoidal que se organizam em um cilindro oco, Fig. 1.3-5 c. Os Ms têm aproximadamente $25 \mathrm{~nm}$ de diâmetro e alta rigidez. Os Ms são muito dinâmicos, até mais que actina, estando em constante polimerização e despolimerização, sua meia-vida é em torno de poucos minutos [1,2]. Dentre suas funções, pode-se citar transporte intracelular e formação do fuso mitótico na divisão celular [1,2].

Filamentos de actina (FAs) é o principal componente quando se está falando de dinâmica do CSK. São polarizados e também podem polimerizar e despolimerizar [4], o que é essencial para migração celular. Os filamentos ficam concentrados embaixo da membrana celular, para 


\section{Introdução}

a F-actina

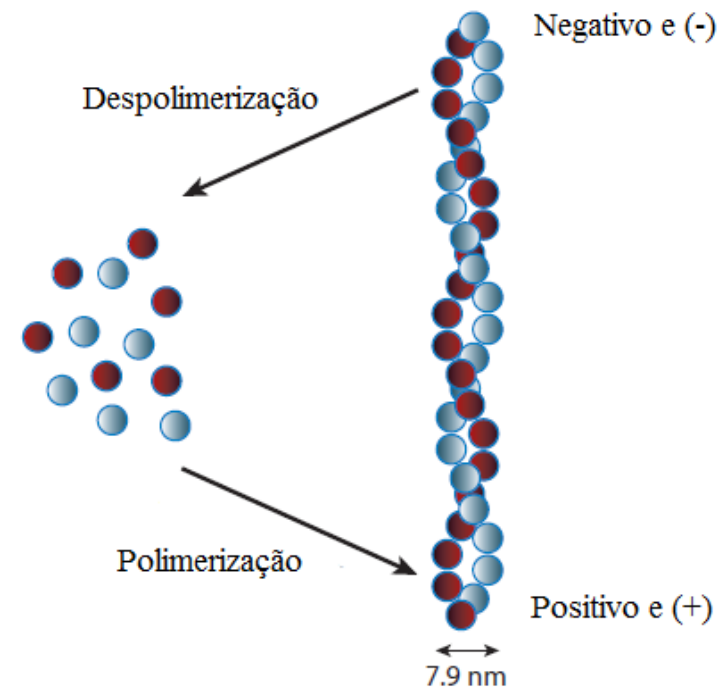

b Filamentos Intermediários

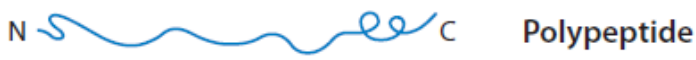

$\mathrm{N} 2 \infty \infty \infty \mathrm{ben}_{\mathrm{C}}$ Dímero

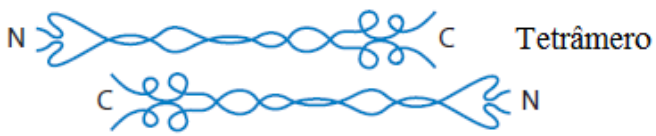

- $\infty \infty-\infty$ है।

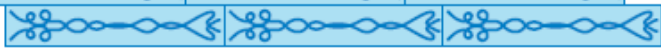

Protofilamento

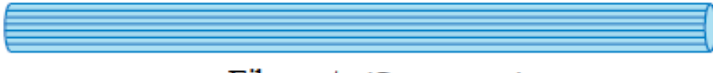

Filamento $(D=10 \mathrm{~nm})$

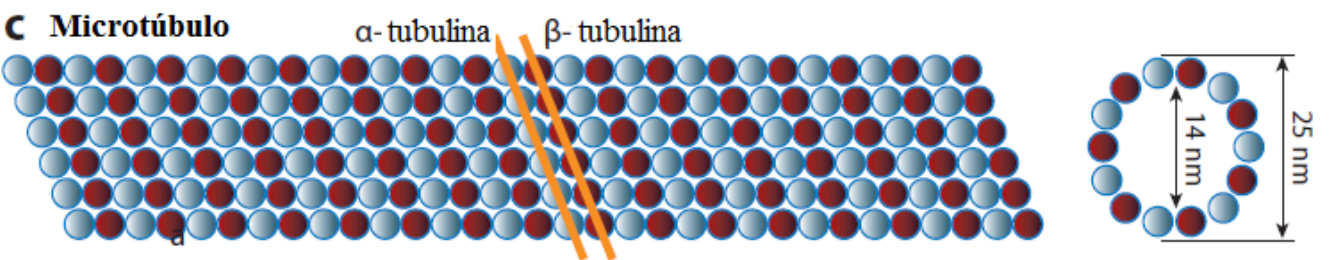

Figura 1.3-5. Constituintes do CSK: a filamentos de actina, b filamentos intermediários e c microtúbulos. As estruturas em marrom representam o núcleo da célula. Figura modificada de [1].

reforçar a superfície celular a resistir à tensão e manter o formato celular [4]. Eles ainda podem interagir com miosina, uma proteína motora, responsável por gerar força contrátil nas redes de actina [4].

FAs são formados pela polimerização de G-Actina, monômero globular, em filamentos torcidos, as F-Actinas, que têm em torno de 7-9 nm de diâmetro [1,2], Fig. 1.3-5 a. Dos filamentos de actina, estruturas terciárias como as "fiber bundles" (fibras de stress) podem ser formadas através da ação de várias proteínas que se ligam a actina [1].

As fibras de stress podem formar as adesões focais, onde a actina é ancorada à integrina, proteína transmembrânica, que se ancoram a proteínas da matriz extracelular [1]. As adesões 
Introdução

focais são responsáveis por cascatas de proteínas que regulam força e crescimento da fibra [1].

A actina é o constituinte primário da maioria das células, constituindo cerca de $10 \%$ de toda proteína nas células. Ela responde rapidamente e dramaticamente a forças externas a tem um papel fundamental em migração celular [1].

\subsection{Microrreologia}

Microrreologia é o estudo das propriedades mecânicas em uma escala microscópica, que pode ser obtida usando dois tipos de técnicas: ativas e passivas, ou técnicas de aplicação de força e sensíveis a forças [17]. Na microrreologia ativa, é aplicada uma distensão, ou pressão, externa em uma sonda e medida a pressão, ou distensão, resultante. Podem-se citar: pinças ópticas, pinças magnéticas e Citometria Óptica de Torção Magnética, Optical Magnetic Twisting Cytometry (OMTC). Nessas técnicas, o que elas têm em comum são que esferas de poucos micrômetros de diâmetro são incorporadas na superfície celular. Então, uma carga mecânica é aplicada nas microesferas, usando pinças ou torções magnéticas [18-20]. Enquanto as microesferas se movem, elas deformam a célula a qual está vinculada, e a célula resiste a esse movimento com uma pressão interna que depende de suas propriedades mecânicas. Pode-se citar outras técnicas que utilizam aplicação de forças, como micropipeta de aspiração, estimulação acústica, aparatos de microfluídica, dentre outras [17].

Na microrreologia passiva usa-se movimentos espontâneos termicamente dirigidos de uma sonda para inferir propriedades mecânicas do meio envolvente. Pode-se citar: microrreologia de um ponto e dois pontos, e difusão anômala [18]. Também pode-se citar outras técnicas sensíveis a forças como microscopia de força atômica (AFM), microscopia de força de tração (TFM), dentre outras [17]. 


\section{Introdução}
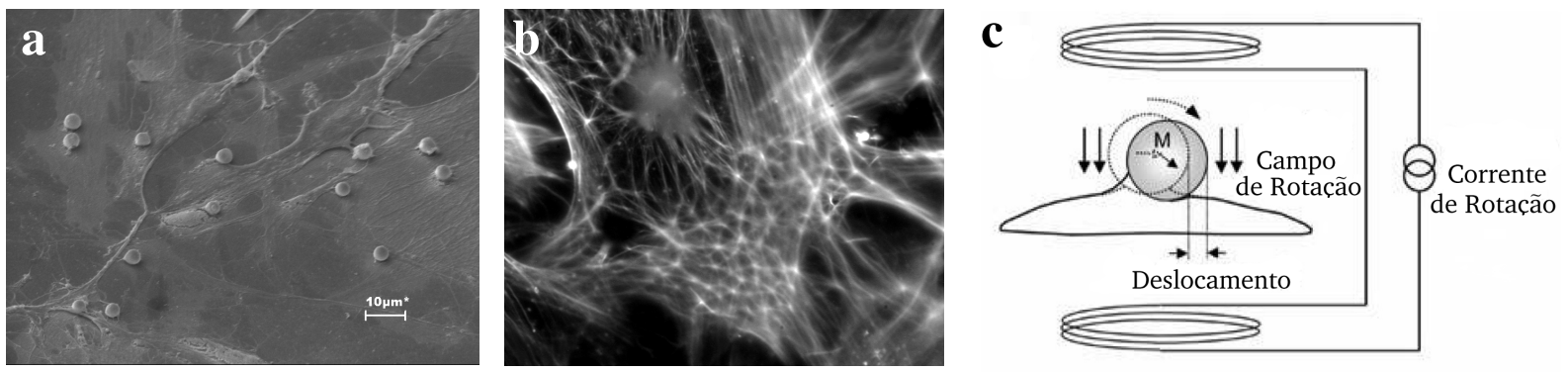

Figura 1.4-6. Microesferas e esquema da citometria óptica de torsão magnética. a: esferas ferrimagnéticas ligadas ao citoesqueleto vistas por microscopia eletrônica de varredura; b: microscopia de fluorescência confocal da esfera na superfície da célula; c: o campo magnético introduz um torque que leva a esfera a rodar e se deslocar. $M$ denota a direção do momento magnético da esfera. Figuras modificadas de [18-20].

\subsubsection{Citometria Óptica de Torção Magnética (OMTC)}

Nesta técnica são utilizadas microesferas ferrimagnéticas cobertas com um peptídeo sintético contendo uma sequência de amino ácido arginine-glycine-aspartic, RGD, que acoplam fortemente a receptores de integrina da célula, se aderindo a ela [21]. As esferas são magnetizadas horizontalmente e então é aplicado verticalmente um campo magnético externo homogêneo, que varia senoidalmente no tempo, gerando um torque, Fig. 1.4-6 [18-20].

Um sistema de aquisição/processamento de imagens é integrado a um microscópio invertido para acompanhar o movimento das microesferas [21]. O torque $T$ é o torque mecânico por volume de esfera e tem dimensão de pressão (Pa). A razão do torque complexo $\tilde{T}$ com o deslocamento complexo resultante $\tilde{d}$ define o módulo elástico complexo da célula $\tilde{g}=\tilde{T}(f) / \tilde{d}(f)$, e tem dimensão de $\mathrm{Pa} / \mathrm{nm}$. Para cada esfera são computados o módulo elástico $g^{\prime}$ (parte real de $\tilde{g}$ ), o módulo de perda $g^{\prime \prime}$ (parte imaginária de $\tilde{g}$ ), e a tangente de perda $\eta$ (a razão $g^{\prime \prime} / g^{\prime}$ ). Essas medições podem ser transformadas nos tradicionais módulos elástico e de perda por um fator geométrico $\alpha$ dependente do formato e da espessura da célula e do grau de aderência, $\tilde{G}=\alpha \tilde{g}=G^{\prime}+i G^{\prime \prime}[19]$. O comportamento dos módulos de armazenagem, $G^{\prime}$ e perda $G^{\prime \prime}$ típico para materiais tipo sólido ou líquido são mostrados na Fig. 1.4-7. Para um fluido tipo líquido, o módulo de armazenagem está muito abaixo do módulo de perda, e sua dependên- 


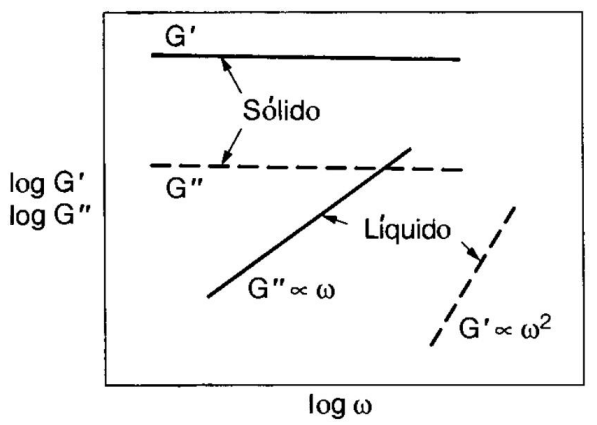

Figura 1.4-7. Comportamento do módulo $\tilde{G}$ para líquidos e sólidos [16]. G' é o módulo de armazenagem, enquanto $G^{\prime \prime}$ o de perda. Para um fluido complexo ou matéria mole, o comportamento seria intermediário ficando entre os dois tipos apresentados. Figura modificada de [16].

cia com $\omega$ é $G^{\prime} \propto \omega^{2}$ enquanto que $G^{\prime \prime} \propto \omega[16]$. A região de baixa frequência, onde $G^{\prime}$ e $G^{\prime \prime}$ obedecem a essas leis de frequência, é chamada de região terminal. Para fluidos tipo sólido, $G^{\prime} \gg G^{\prime \prime}$, e $G^{\prime}$ é quase independente da frequência. Um fluido complexo apresenta um comportamento intermediário ao mostrado na Fig. 1.4-7, ficando entre os dois tipos apresentados [16].

\subsubsection{Difusão Anômala e a Relação de Stokes-Einstein Generalizada}

A difusão ocorre comumente na natureza, e pode ser caracterizada pela dependência do MSD com o tempo. Já na difusão anômala, o MSD não depende linearmente do tempo, assim: $\left\langle\Delta r^{2}(\Delta t)\right\rangle \propto \Delta t^{\beta}$, onde se $\beta>1$, tem-se um processo superdifusivo, e se $\beta<1$, subdifusivo. Difusão anômala pode ser observada, por exemplo, em fluidos complexos e diversos materiais biológicos, e ser usada para medir e entender a dinâmica desses materiais.

Uma das mais importantes propriedades dinâmicas de um material é sua susceptibilidade elástica, ou seja, sua resposta a uma excitação cisalhante [22]. Por exemplo, a diferença primária entre um fluido e um sólido é sua contrastante resposta a uma tensão cisalhante aplicada: sólidos armazenam energia mecânica e são elásticos, enquanto fluidos dissipam energia mecânica e são viscosos [22]. Muitos materiais são viscoelásticos, tanto armazenam como dissipam energia, 


\section{Introdução}

como por exemplo os fluidos complexos.

Fluidos complexos podem ser descritos como um material composto de uma base líquida onde estão presentes estruturas supramoleculares como por exemplo polímeros [23]; desses materiais pode-se citar surfactantes e outros fluidos biológicos. Nesses fluidos então, não se tem mais uma viscosidade $\eta$ constante, mas sim, uma viscosidade $\eta^{*}(\omega)$ complexa e dependente da frequência. Assim, a relação de Stokes-Einstein, que foi desenvolvida primariamente pensando em fluidos Newtonianos, fluidos viscosos, não pode ser utilizada para fluidos complexos. Assim, foi desenvolvida a relação de Stokes-Einstein generalizada (GSER), encontrada com a utilização da teoria de Langevin, ver Apêndice B.

A GSER diz que da medida do MSD sobre intervalos de tempo pode-se deduzir $\tilde{G}(f)$, assim:

$$
\left\langle r^{2}(\Delta t)\right\rangle=\Im^{-1}\left(\frac{k_{B} T}{\pi a i f \tilde{G}(f)}\right),
$$

onde $a$ é o raio da partícula, $\Im^{-1}($.) é a transformada inversa de Fourier, $f$ a frequência, e $i^{2}=-1$. Para mais detalhes, ver Apêndice B.

A GSER é a relação de Stokes-Einstein generalizada para um material viscoelástico dependente da frequência. É válida somente para sistemas em equilíbrio térmico, onde movimentos casuais são dirigidos apenas por forças térmicas.

No caso de estudos do CSK, pode-se medir os movimentos espontâneos de microesferas fixadas a ele. Esse procedimento é baseado na hipótese de que, a menos de flutuações térmicas, a microesfera pode se mover somente se a estrutura na qual ela está afixada se rearranjar [7]. Assim, o MSD medido descreve a contínua reorganização interna do CSK com o tempo. 


\section{Introdução}

\subsection{A Teoria dos Materiais Vítreos Moles}

Materiais moles envolvem colóides, polímeros, surfactantes, emulsões, meio granular, etc. Embora muito diferentes estruturalmente, o comportamento mecânico de cada uma dessas substâncias é muito parecido [18,20]. Todas são muito moles, soft, (variando de $1 \mathrm{~Pa}$ a $1 \mathrm{kPa}$ ), os módulos de armazenagem $G^{\prime}$ e perda $G^{\prime \prime}$ aumentam com a mesma dependência, uma lei de potência fraca na frequência, e a razão $G^{\prime \prime} / G^{\prime}$ não muda com a frequência e é da ordem de $0.1[18,24,25]$. Sollich [25], baseado na teoria de Bouchaud [26], desenvolveu um modelo de reologia para materiais moles, Soft Glassy Rheology (SGR), ver Apêndice C. Este é um modelo fenomenológico que almeja explicar as principais características da reologia do SGM. As características gerais que todos os SGM compartilham são de que todos são compostos por numerosos e discretos elementos, que estão agregados via interações fracas, e também exibem uma inerente desordem estrutural e metastabilidade [18, 24, 25, 27]. Todas essas características citadas acima estão presentes no CSK de células vivas [27].

Utilizando esse modelo, OMTC e difusão anômala de microesferas, pode se estudar o CSK do ponto de vista de SGM. Os movimentos das microesferas mostram uma dinâmica intermitente com períodos de confinamento e de saltos [7]. No trabalho de Bursac et al. [7] são estudados movimentos espontâneos e forçados, por torque, de microesferas em células vivas. Segundo este trabalho, o MSD como função de $\Delta t$ exibe um comportamento subdifusivo para pequenos $\Delta t$ 's e superdifusivo para grandes $\Delta t$ 's, como mostrado na Fig. 1.5-8, onde as linhas sólidas representam o coeficiente $\beta$ que é dado por MSD $\propto \Delta t^{\beta}$. O regime subdifusivo está associado com períodos de confinamento e o superdifusivo, com períodos de saltos. Segundo Bursac et al. [7], o módulo elástico da célula mostra uma dependência fraca com a lei da potência da frequência, $G^{\prime}(f) \approx f^{x-1}$. A medida que $x \rightarrow 1$ o sistema aproxima-se de um comportamento puramente elástico, e na teoria de SGR, o sistema aproxima-se de uma transição vítrea. 


\section{Introdução}

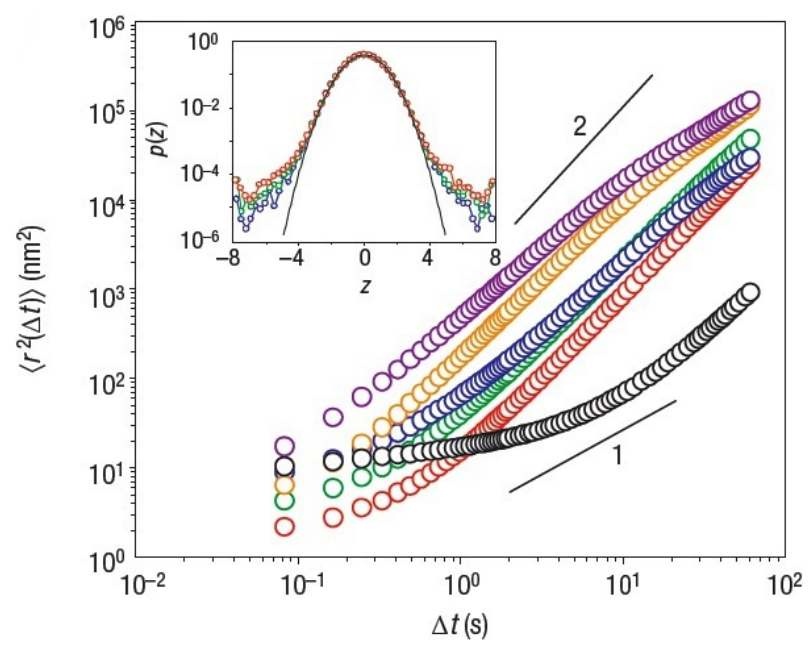

Figura 1.5-8. Gráfico do deslocamento quadrático médio MSD por $\Delta t$ das microesferas sob variadas condições: a $25{ }^{\circ} \mathrm{C}$, a $37{ }^{\circ} \mathrm{C}$, a $41{ }^{\circ} \mathrm{C}$, com o uso de DBcAMP (diminui a contratibilidade da célula), com o uso de Jasplakinolide (estabiliza a actina) e com o uso de droga que depleta o ATP celular. É possível observar que para pequenos $\Delta t$ 's, o MSD exibe um comportamento subdifusivo, enquanto que para grandes $\Delta t$ 's, exibe um comportamento superdifusivo. As retas sólidas indicam inclinação $\beta=1$ e 2 do MSD, onde $\beta$ é dada por $\operatorname{MSD} \propto \Delta t^{\beta}$. Figura interna: gráfico de $p(Z)$ por $Z$, onde $Z$ é o deslocamento das microesferas normalizado pela média dos deslocamentos e pelo desvio padrão, ver Eq. 1.11. A linha contínua representa a Gaussiana que melhor se ajusta aos dados. Figura modificada de [7].

Bursac et al. [7] inseriu algumas variáveis ao problema. Estudou o deslocamento das microesferas a diferentes temperaturas, $25,37 \mathrm{e} 41^{\circ} \mathrm{C}$, e inserindo drogas que modulam a estrutura do CSK: DBcAMP (diminui a contratibilidade da célula), Jasplakinolide (estabiliza a actina), e que induzem a depleção do ATP intracelular, como mostrado na Fig. 1.5-8. Como esperado, com o aumento da temperatura, $T$, observa-se um aumento do MSD, ou seja, quanto maior $T$, maiores os deslocamentos da esfera, e as características da difusão permanece para todos os casos. Os deslocamentos foram normalizados da seguinte maneira:

$$
Z=\frac{(\Delta y-\overline{\Delta y})}{\operatorname{STD}},
$$

onde $\Delta y$ é o deslocamento na direção $y$ para cada $\Delta t, \overline{\Delta y}$ é a média e STD é o desvio padrão. Na figura interna da Fig. 1.5-8, é mostrada a distribuição de probabilidade $p(Z)$ dos $Z$ 's. Podese observar que para aproximadamente $|Z|>4$ há uma quebra do comportamento Gaussiano, gerado pelo movimento do CSK com uso de ATP.

Na literatura são encontradas várias hipóteses, como que as técnicas que serão empregadas neste projeto medem a dinâmica do CSK, e que as células vivas se comportam como um SGM. Essas hipóteses ainda estão em aberto e o desenvolvimento de modelos para os processos 


\section{Introdução}

difusivos na célula podem contribuir para o esclarecimento dessas hipóteses.

\subsection{Migração Celular}

Metástase, invasão, cicatrização, morfogênese, dentre outros, dependem da migração celular coletiva $[10,28,29]$. Embora de suma importância, a migração coletiva ainda é pobremente entendida. Como exemplo de questões ainda a serem entendidas, pode-se pensar em uma monocamada de células epiteliais em migração, onde têm-se as células da borda, leading edge e as internas. Assim, no processo de migração, existem várias perguntas, ainda não estabelecidas, como por exemplo: as células da borda exercem forças físicas localmente que são transmitidas para as outras dentro da camada, através das junções célula-célula, levando a monocamada a se locomover? Ou, cada célula individual é mecanicamente auto-propulsora? Ou a proliferação celular expande a colônia celular, assim empurrando as células para a frente? [10,30]. Quais são as forças envolvidas?

As forças físicas envolvidas na migração celular, Fig. 1.6-9 incluem forças suportadas pelo CSK, forças exercidas pelas adesões entre células e substrato (flechas vermelhas) e forças exercidas através das junções célula-célula (flechas azuis) [28], mecanismo conhecido como cabo de guerra. As flechas em vermelho representam a tração, enquanto que as flechas em azul representam a tensão. A tensão na monocamada reflete a acumulação espacial das forças de tração e equivalentemente, as forças de tração local é a derivada espacial do tensão intercelular [28]. A técnica usada para se obter as trações é conhecida como microscopia de força de tração (TFM). Para mais detalhes, ver Seção 8.1.

Como características marcantes da migração celular, podem-se citar: heterogeneidade dinâmica, cooperatividade e aprisionamento dinâmico [10,28-31]. Calculando as forças inter- 


\section{Introdução}

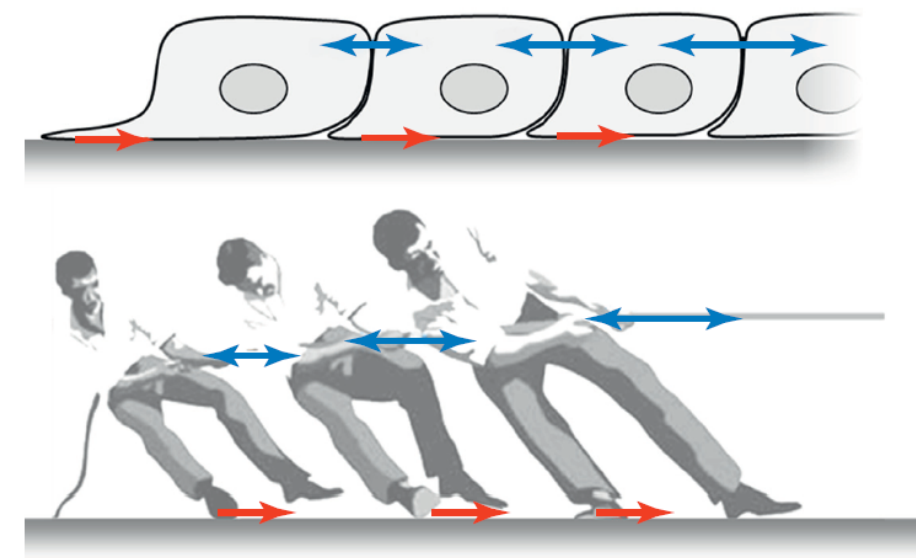

Figura 1.6-9. Mecanismo conhecido como cabo de guerra, onde as células usam as trações locais (flechas em vermelho) para obter gradientes de longo alcance de tensão intra e intercelular (flechas em azul). Figura modificada de [28].

celulares, esta mostra uma grande heterogeneidade, que também é dinâmica. A Fig. 1.6-10 mostra uma imagem da tensão, onde podem-se ver grandes picos e vales, que mudam com o tempo [31]. A migração celular, flechas em vermelho, segue a orientação da tensão, elipses azuis. Ou seja, a direção da migração, flechas em vermelho, segue a direção do principal estresse máximo, onde o cisalhamento é mínimo, ver Fig. 1.6-11. Esse movimento celular, plithotaxis, é coletivo, fortemente cooperativo e vítreo dinamicamente. Para maiores detalhes ver Tambe et al. [31].

Esta tendência, chamada plithotaxis, na qual a velocidade da migração segue a orientação local da máxima tensão principal, ou seja, a orientação da elipse de tensão, é um potente mecanismo guia da coletividade celular e é mediado através das junções célula-célula $[10,28,31]$.

A densidade celular também tem um papel importante nesse cenário, ver Fig. 1.6-12. A medida que a densidade celular aumenta em uma monocamada, os blocos cooperativos, ou clusters, se tornam maiores e mais lentos [29], ou seja, as células se tornam altamente aprisionadas por seus vizinhos. A área média das regiões de maiores velocidades define $\xi_{h}$, a área da heterogeneidade dinâmica. Então, a densidade aumentando pode-se levar a uma transição da 


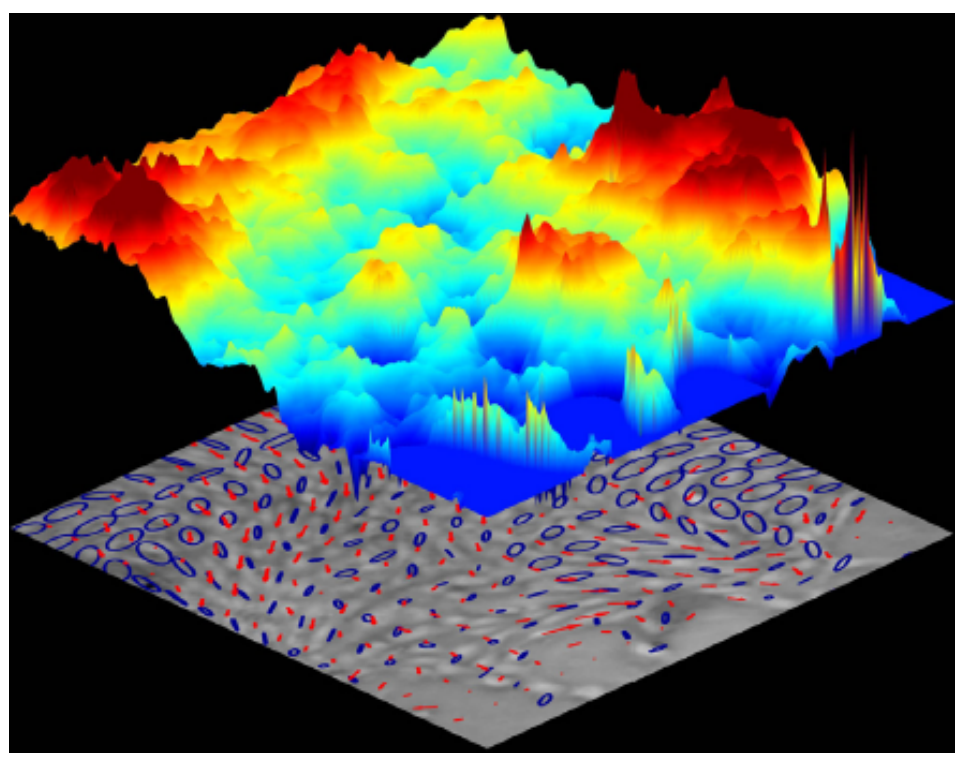

Figura 1.6-10. Tensão calculada a partir de uma monocamada celular. A migração celular, flechas em vermelho, segue a orientação da tensão, elipses azuis. O movimento celular, plithotaxis, é coletiva, fortemente cooperativa e vítrea dinamicamente. Figura modificada de [31].

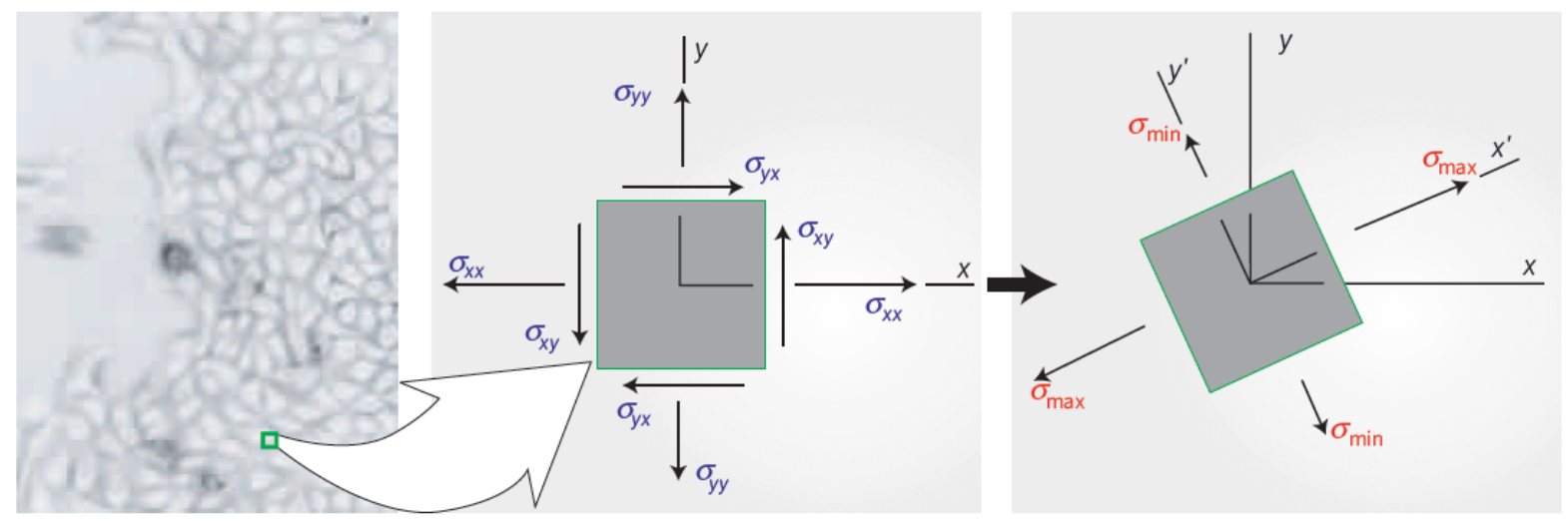

Figura 1.6-11. Representação dos estresses em uma monocamada celular. Em cada ponto da monocamada os estresses intercelulares têm componentes normais $\left(\sigma_{x x}\right.$ e $\sigma_{y y}$ ) e de cisalhamento ( $\sigma_{x y}$ e $\sigma_{y x}$ ). Pode-se então rotacionar o objeto em questão para $\left(x^{\prime}, y^{\prime}\right)$ até que o cisalhamento desapareça e se tenha $\sigma_{\max } \mathrm{e}$ $\sigma_{m i n}$, chamados principal stresses. Os novos eixos encontrados são chamados de principal orientations. Figura modificada de [31].

monocamada de um estado tipo fluido para um estado tipo sólido [10].

Todas essas características olhadas juntas em estudos de matéria inerte condensada mole compreendem as principais características de uma transição vítrea que está associada com jamming [10]. Desta maneira, é razoável se perguntar se a hipótese jamming poderia unificar em 


\section{Introdução}

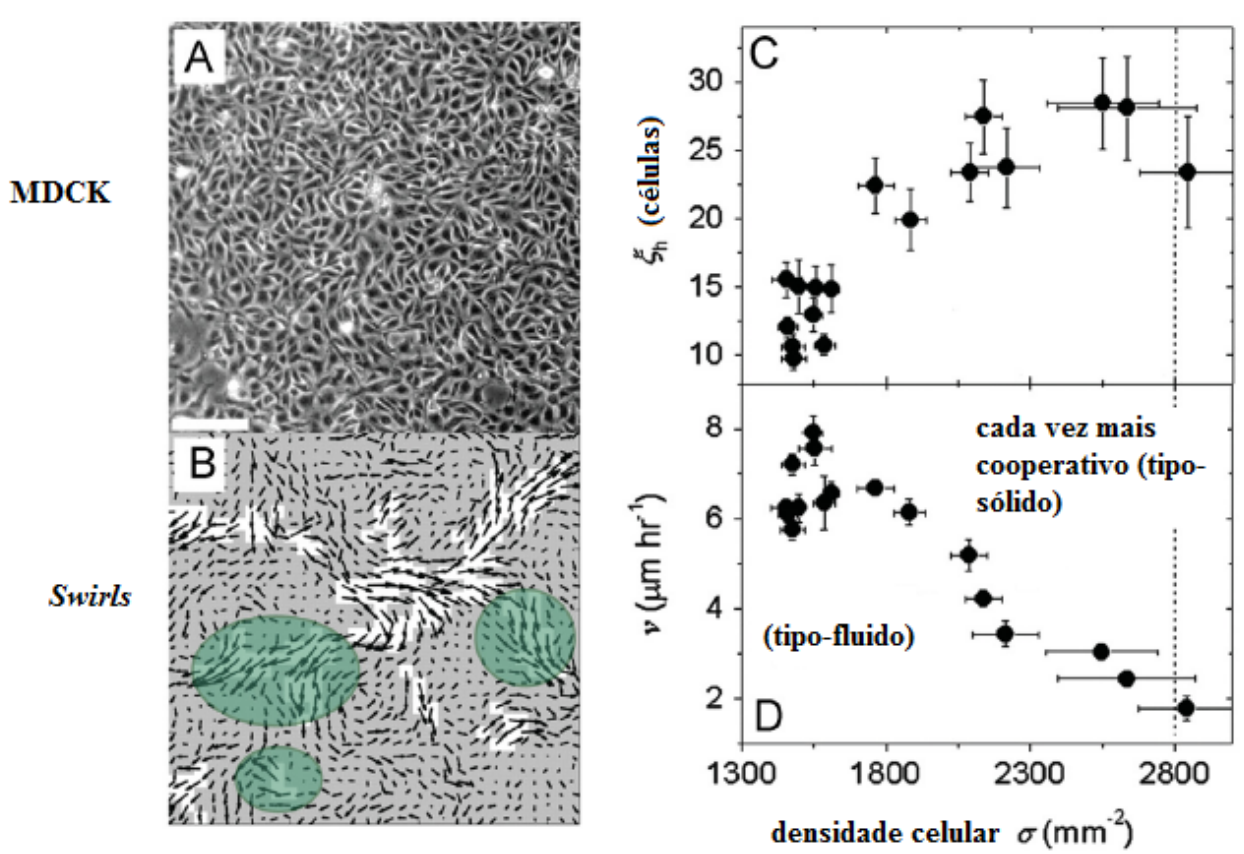

Figura 1.6-12. Células MDCK em uma monocamada confluente migram de maneira heterogênea espacialmente (A, B). A área média das regiões de maiores velocidades define $\xi_{h}$, a área da heterogeneidade dinâmica (B regiões brancas). A medida que a densidade aumenta, $\xi_{h}$ cresce $(\mathrm{C})$. A velocidade de migração média do campo de visão, $v$, diminui com o aumento da densidade (D). Barra de escala $100 \mu \mathrm{m}$. Figura modificada de [29]

um quadro mecanicista os efeitos de diversos fatores biológicos descritos anteriormente [10]. Dessa maneira, Sadati et al. [10] propuseram um diagrama de fase jamming hipotético, Fig. 1.613.

Neste diagrama os eixos são relativos à densidade, adesão e motilidade. A medida que as células se tornam mais densas, mais aderidas ou com menor motilidade, as coordenadas associadas no diagrama de fase se movem progressivamente para mais perto da origem e o estado da monocamada torna-se altamente jammed. Um exemplo é mostrado no diagrama. As flechas indicam velocidade de migração, e as cores indicam os clusters de células que se movem coletivamente. Vetor são células num estado controle (MCF10A-vector), existindo perto de uma transição jamming, onde células se movem em clusters que se tornam progressivamente maiores ou menores a medida que a transição jamming se aproxima ou se afasta. Superexpressão 


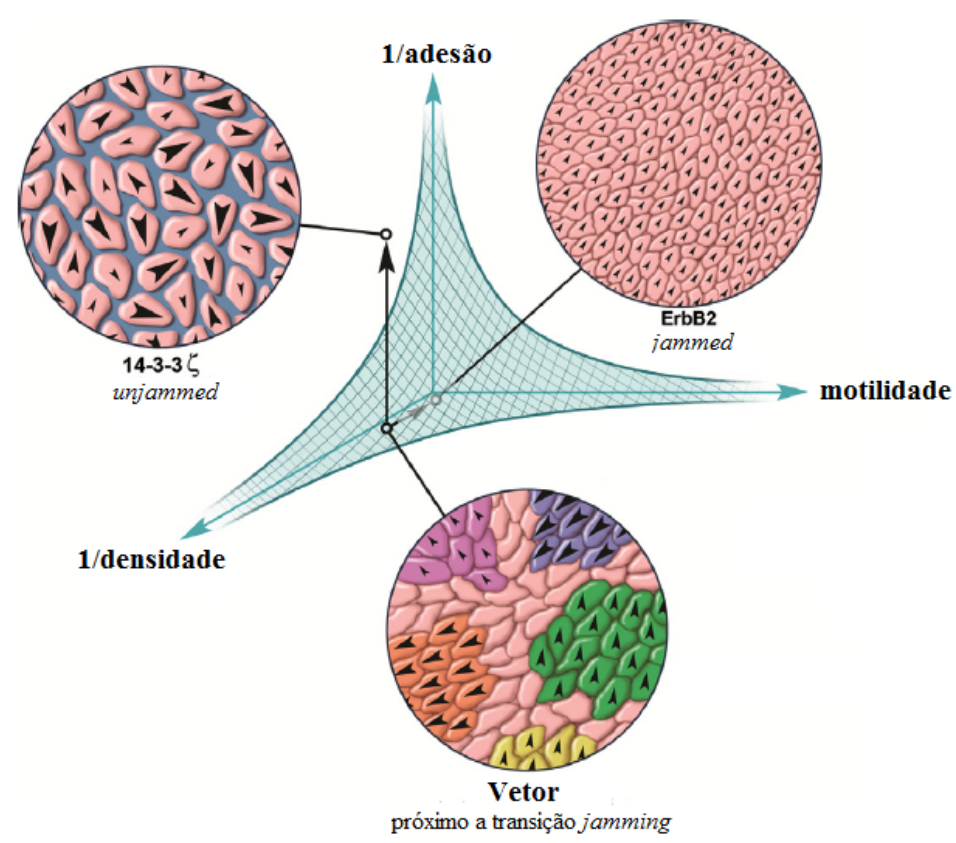

Figura 1.6-13. Diagrama de fase jamming hipotético para uma monocamada celular. A medida que as células se tornam mais densas, mais aderidas e com menos motilidade, as coordenadas associadas no diagrama de fase se movem progressivamente para mais perto da origem e o estado da monocamada torna-se altamente jammed. Uma transição em direção a um estado jammed e resultante dinâmica vítrea é mostrada na imagem. As flechas indicam velocidade de migração, e as cores indicam os clusters de células que se movem coletivamente. Vetor: células num estado controle (MCF10A-vector) existe perto de uma transição jamming, onde células se movem em clusters que se tornam progressivamente maiores ou menores a medida que a transição jamming se aproxima ou se afasta. Superexpressão do oncogene ErbB2: a medida que as células proliferam e a monocamada se torna mais densa, os clusters se tornam maiores e mais lentos. Superexpressão do oncogene 14-3-3 $\zeta$ : a medida que as junções célula-célula perdem adesão, a monocamada se torna fluidizada, unjammed, e a coletividade é perdida. Figura modificada de [10]

do oncogene ErbB2 (aumento da função do gene): a medida que as células proliferam e a monocamada se torna mais densa, os clusters se tornam maiores e mais lentos. Superexpressão do oncogene 14-3-3 $\zeta$ : a medida que as junções célula-célula perdem adesão, a monocamada se torna fluidizada, unjammed e a coletividade é perdida [10].

Outros eixos ainda poderiam ser imaginados, como por exemplo rigidez da célula, rigidez do substrato, volume celular, dentre outros [10]. Por outro lado, o uso desse diagrama e a hipótese de cell jamming pode levar a questões nunca pensadas anteriormente como por exemplo: a monocamada epitelial tende a formar um agregado tipo sólido com uma função de barreira excelente com pequena possibilidade de invasão ou escape celular, por que as células estão 


\section{Introdução}

jammed?; a cicatrização requer cell unjamming?

Neste contexto pode-se perguntar qual seria a relação entre cell jamming e a extrusão celular em monocamadas superconfluentes, recentemente reportada em $[32,33]$. Escolhendo um eixo do diagrama de fase, no caso densidade, pode-se explorar a transição jamming que ocorre na extrusão celular e ajudar a entender melhor essa nova hipótese em relação a biologia e mecânica da monocamada celular. Escolhendo também diferentes tipos celulares, pode-se avaliar a diferença entre o comportamento de células epiteliais e de músculo liso, e comparar o seu comportamento coletivo com o comportamento individual da dinâmica do CSK.

A dinâmica do CSK está envolvida em processos cruciais para as células. Além de ser um indicativo da integridade celular, ela pode também ser alterada devido a patologias e também sob o uso de fármacos. Desta maneira, o entendimento da dinâmica do CSK, tanto do ponto de vista metabólico como mecânico, é de extrema importância para o entendimento dos processos celulares, individuais ou coletivos.

\subsection{Estrutura do Texto}

O texto será estruturado em capítulos independentes. Cada capítulo com caráter experimental será composto de introdução, métodos, resultados e discussões e conclusões.

O Cap. 3 tratará das características mais gerais do comportamento do CSK. Como este se remodela e o que se pode inferir a partir dessa análise. No Cap. 4 serão investigadas as correlações temporais e espaciais das anomalias mostradas no Cap. 3. No Cap. 5 será mostrado a análise estatística para dados frequenciais. No Cap. 6 serão investigadas maneiras de se evidenciar essas anomalias. Já no Cap. 7 será desenvolvida uma modelagem para o comportamento do CSK com o intuito de entender melhor as origens de suas anomalias. 


\section{Introdução}

O capítulo seguinte se refere a projetos paralelos que se iniciaram após o período sanduíche da aluna no grupo do professor Jeffrey Joseph Fredberg do Laboratory for Molecular and Integrative Cellular Dynamics [34] em Harvard School of Public Health em Boston. Assim, esse capítulo está em fase de desenvolvimento, sendo prováveis projetos para o pósdoc da aluna. A Seção 8.1 se refere ao estudo das propriedades mecânicas de cardiomiócitos. E a Seção 8.2 irá tratar do comportamento da célula em uma monocamada celular e qual a relação da hipótese jamming com a extrusão celular em monocamadas supeconfluentes. 


\section{Capítulo 2}

\section{Objetivos}

Esse trabalho tem como objetivo principal quantificar e analisar a dinâmica de micro e nano esferas acopladas direta e indiretamente a células aderentes vivas, objetivando a caracterização mecânica das mesmas. Nesse contexto, serão utilizadas três tipos de células: epiteliais, de músculo liso e cardiomiócitos.

Dinâmica celular evidenciada por difusão de microesferas - quantificar a atividade mecânica do CSK a partir de parâmetros e correlações obtidos de experimentos de difusão com microesferas, diferenciando as respostas entre células epiteliais e de músculo liso.

1. enumerar as características gerais da movimentação e do remodelamento do CSK em células usando princípios difusivos da mecânica estatística (Capítulo 3).

2. identificar as correlações temporais e espaciais desse remodelamento (Capítulo 4).

3. identificar a distribuição dos eventos raros e os erros nos dados frequenciais (Capítulo 5).

4. evidenciar os fenômenos anômalos através da aquisição de imagens a altas frequências (Capítulo 6). 
Objetivos

5. desenvolver uma modelagem do comportamento do CSK baseado em movimento Browniano para melhor entender suas origens (Capítulo 7).

Mecânica de cardiomiócitos evidenciada por rastreamento de micro e nano esferas - caracterizar mecanicamente cardiomiócitos utilizando a movimentação ativa de microesferas e utilizando a técnica de Microscopia de Força e Tração, que rastreia nano esferas (Seção 8.1).

1. quantificar parâmetros referentes ao batimento celular, como frequência e amplitude.

2. quantificar as forças produzidas no substrato durante o batimento.

3. demonstrar os princípios metodológicos comparando o rastreamento de micro esferas com a técnica de microscopia de força de tração.

\section{Dinâmica de grupos celulares evidenciada por microscopia óptica e difusão de microesferas}

- quantificar o comportamento de uma monocamada confluente quando esta sofre uma compressão (Seção 8.2).

1. mensurar a dinâmica de grupos celulares em uma monocamada.

2. identificar a formação de agregados celulares, clusters.

3. descrever a conexão entre a dinâmica de agregados com a hipótese jamming.

4. conectar as atividades internas com as externas para as células epiteliais e de músculo liso. 


\section{Capítulo 3}

\section{Difusão Anômala e a Dinâmica do}

\section{Citoesqueleto}

Por meio da observação da difusão, pode-se inferir características da dinâmica do citoesqueleto (CSK) usando microesferas incorporadas à superfície celular. A hipótese usada é que a microesfera só pode se mover se a estrutura ao qual ela está conectada se mover também. Desta maneira, observando-se o movimento das microesferas, observa-se o remodelamento do CSK. Como já comentado na Seção 1.5, o que é encontrado com esse experimento é uma dinâmica intermitente, cujo deslocamento quadrático médio (MSD) mostra inicialmente para $\Delta t$ s pequenos um comportamento subdifusivo e posteriormente para $\Delta t$ s grandes um comportamento superdifusivo [7]. Outras características encontradas foram relaxamento lento (slow relaxation), aprisionamento cinético e quebra do teorema da flutuação-dissipação [7,35,36]. Essas características dinâmicas olhadas juntas remetem fortemente a materiais vítreos moles (SGM) [25], e são reforçadas pelas propriedades encontradas usando movimentação forçada das microesferas, no caso citometria óptica de torção magnética (OMTC). Neste caso foram observados reologia livre de escala [19,37], envelhecimento mecânico (mechanical aging) [7] e fluidização indu- 


\section{Difusão Anômala e a Dinâmica do Citoesqueleto}

zida por cisalhamento [7,35], o que vem gerando então diversas analogias entre células e SGMs nos últimos anos $[7,19,35,37,38]$.

As características obtidas passivamente, que são os alvos dessa tese, têm sido observadas em diversas células, como fibroblastos de pulmão fetal humano, células endoteliais vascular pulmonar de ratos, células epiteliais e células de músculo liso de vias aéreas de humanos [7]. As evidências encontradas mostram que os movimentos espontâneos das microesferas não são apenas térmicos, ou seja, apresentam um comportamento anômalo que é governado por uma fonte adicional de energia, no caso o ATP. Esse comportamento anômalo é então atribuído ao remodelamento dos filamentos de actina em nível molecular dirigidos pelos motores de miosina, uma vez que movimentos relacionados ao movimento da célula inteira, movimentos da membrana lipídica, polimerização e despolimerização dos filamentos de actina e dinâmica da adesão focal não são significativos $[7,36]$.

Por mais que se encontrem trabalhos acerca do fenômeno anômalo observado passivamente, estes ainda são poucos e o conhecimento que se tem sobre ele ainda é pobre. Assim, nesse capítulo, serão realizados experimentos de difusão e identificadas algumas de suas características para melhor compreender e entender esse fenômeno. Também serão testadas algumas novas variáveis, como diâmetro diferente de microesferas, e também frequências diferentes de aquisição das imagens, o que espera-se levar a novas abordagens para a compreensão desse fenômeno.

\subsection{Métodos}

Para o experimento de difusão serão utilizadas células epiteliais (BEAS-2B - célula epitelial aderente brônquica humana normal) que são cultivadas no $\mathrm{LabM}^{2}$, Laboratório de Microrreologia e Fisiologia Molecular (http://fig.if.usp.br/ labm2/index.html). Os 


\section{Difusão Anômala e a Dinâmica do Citoesqueleto}

\begin{tabular}{cccccc}
\hline Série & Microesfera & Magnificação & Tempo (s) & Frequência (fps) & $N_{\text {beads }}$ \\
\hline A & ferrimagnética & $10 \times$ & 300 & 10 & 42 \\
B & ferrimagnética & $10 \times$ & 300 & 20 & 32 \\
C & ferrimagnética & $10 \times$ & 300 & 30 & 30 \\
D & látex & $40 \times$ & 300 & 10 & 19 \\
E & látex & $40 \times$ & 300 & 20 & 17 \\
F & látex & $40 \times$ & 300 & 30 & 19 \\
\hline \hline
\end{tabular}

Tabela 3.1. Desenho experimental.

detalhes do cultivo estão descritos no Apêndice D. As microesferas são recobertas com um peptídeo sintético contendo uma sequência de aminoácidos arginine-glycine-aspartic (Arg-Gly-Asp - RGD). Estas microesferas se acoplam fortemente às células através dos receptores de integrina ficando ancoradas ao CSK. As células são dispostas em poços de 96 numa densidade de 20.000 células por poço mantidas no incubador até atingir confluência. Após confluência, o meio é trocado por meio sem serum bovino e mantido durante o período de uma noite no incubador. Aproximadamente 10.000 microesferas são adicionadas a cada poço e incubados por 20 min antes das medidas experimentais. Para maiores detalhes, ver Apêndice D.

Para aquisição das imagens, uma câmera CCD (Pike AVT) é anexada a um microscópio invertido (Leica DMI4000 B) que transmite as imagens a um computador através da placa de vídeo (National Instruments PCI-6251) onde um software desenvolvido no laboratório feito em C++ irá analisá-las, ver Fig. 3.1-1. Este software identifica as microesferas e a partir do cálculo do centro de massa, detecta as suas coordenas. Esse procedimento é feito para cada frame, onde obtém-se os deslocamentos por tempo. Para maiores detalhes do software, ver Apêndice E.

Para esses experimentos foram utilizadas dois tipos de microesferas: ferrimagnéticas de $4.1 \mu \mathrm{m}$ de diâmetro e de látex de $2.4 \mu \mathrm{m}$ de diâmetro, ver Apêndice F. Foram realizadas 3 séries de experimentos para cada tipo de esferas com diferentes valores de frequência de aquisição de imagens e o total de microesferas, $N_{\text {beads }}$, analisados. Os parâmetros utilizados estão mostrados na Tab. 3.1. 


\section{Difusão Anômala e a Dinâmica do Citoesqueleto}

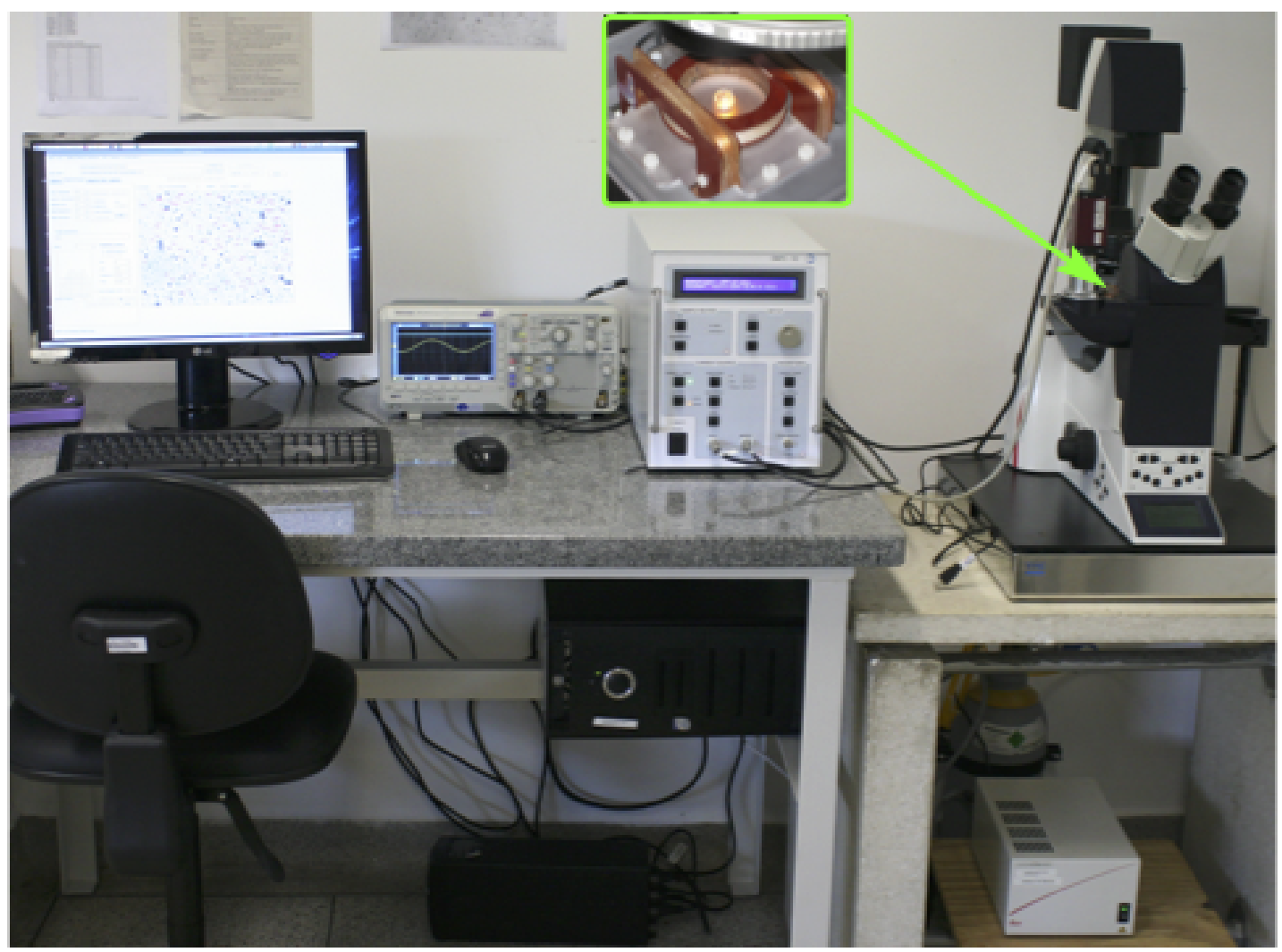

Figura 3.1-1. Aparato experimental. Microscópio invertido com câmera acoplada ligadas ao computador. Em destaque, local onde se encaixa os poços.

Após realizar as medidas experimentais, foram analisados os deslocamentos das microesferas por tempo. Desse deslocamento é subtraído o drift, que é o deslocamento médio por tempo, para evitar efeitos de algum tipo de movimento coletivo que possa ocorrer, como o do estágio do microscópio. Os deslocamentos corrigidos com o drift são então definidos como:

$$
\widetilde{\Delta x_{i}}(t)=\Delta x_{i}(t)-\frac{1}{N} \sum_{i=1}^{N} \Delta x_{i}(t)
$$

onde o índice $i$ se refere a diferentes microesferas, $N$ é o número total de microesferas, $\Delta x_{i}(t)$ seria o deslocamento no tempo $t$, e $\widetilde{\Delta x_{i}}(t)$ é o deslocamento corrigido com a subtração do drift. A correção é similar para o eixo $y$. 


\section{Difusão Anômala e a Dinâmica do Citoesqueleto}

A partir daí foram calculados o MSD, Seção 1.1.2, o $Z$, Seção 1.5 e a inclinação $\beta$ do MSD. Para a inclinação, é considerado que o MSD é proporcional ao tempo da seguinte maneira: MSD $\propto \Delta t^{\beta}$, onde $\beta$ é a inclinação local do MSD. Assim:

$$
\beta=\frac{\partial \ln (\mathrm{MSD})}{\partial \ln (\Delta t)} .
$$

Em todos os cálculos feitos foram considerados os eixos $x$ e $y$ distintamente. Isso é feito por causa de possíveis alinhamentos das células nos poços, o que levaria às microesferas a ter uma maior facilidade de se locomover na direção desse alinhamento do que na direção perpendicular a ele. Separando os eixos pode-se observar esse tipo de comportamento.

Os deslocamentos das microesferas foram analisados normalizando-os da seguinte maneira:

$$
Z_{x, y}=\frac{\Delta x, y-\overline{\Delta x, y}}{\operatorname{STD}_{x, y}}
$$

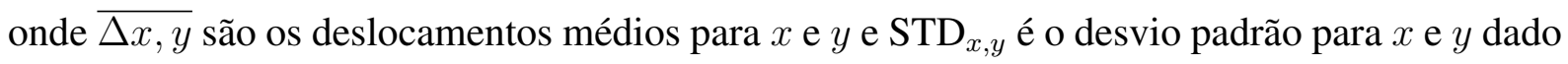
por $\operatorname{STD}_{x}=\left(\frac{1}{n-1} \sum_{i-1}^{n}\left(\Delta x_{i}-\overline{\Delta x}\right)^{2}\right)^{1 / 2}$. Idem para $\operatorname{MSD}_{y}$.

\subsection{Resultados e Discussão}

Foram realizados neste capítulo experimentos com diferentes frequências e microesferas como determinados na Tab.3.1. Os resultados e análises realizadas serão apresentados divididos em seções para facilitar o entendimento. Essas subseções serão sobre: o comportamento geral observado nos experimentos, a dinâmica da movimentação observada, uma proposta de modelo, os tipos de microesferas, a frequência de aquisição, a magnificação usada e o ruído na medida, o tipo celular observado e o que esperar para os próximos capítulos. 


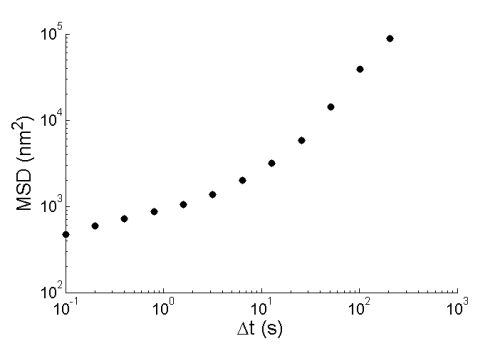

(a)

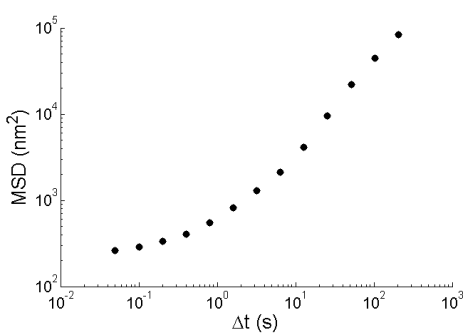

(d)

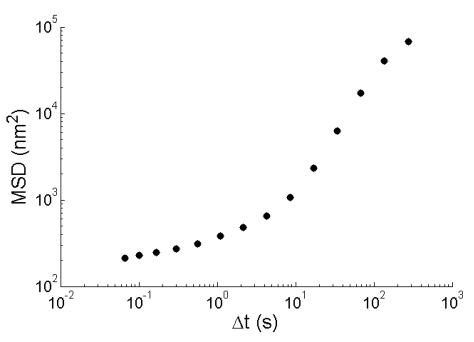

(g)

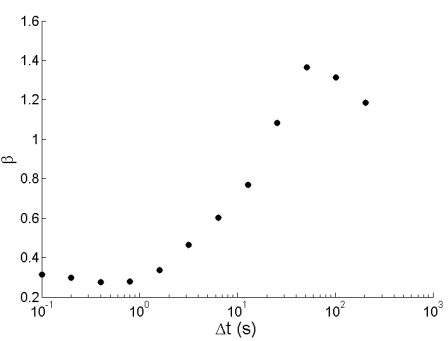

(b)

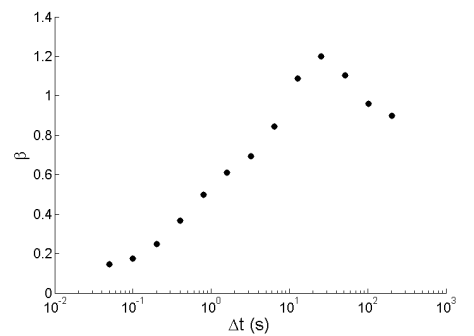

(e)

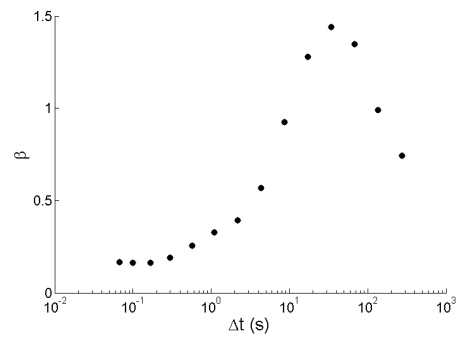

(h)

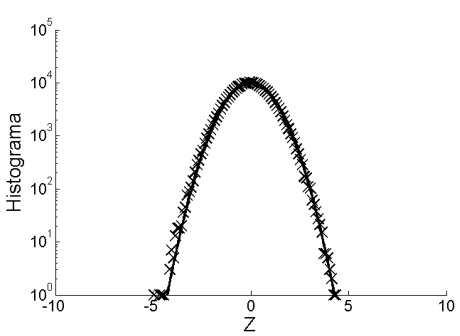

(c)

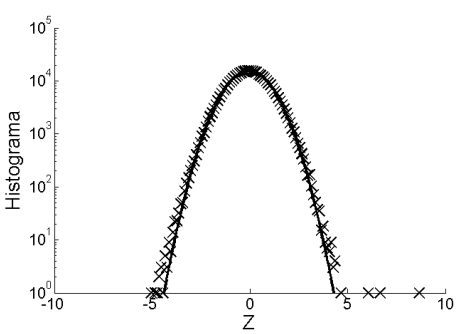

(f)

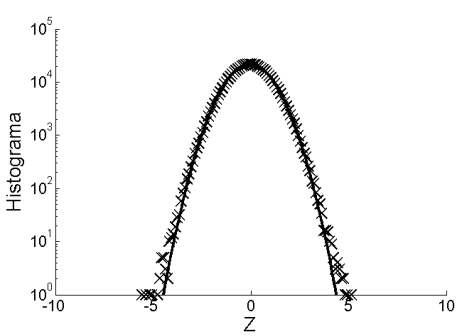

(i)

Figura 3.2-2. Experimentos com esferas ferrimagnéticas. Todos os gráficos foram feitos para $r$. Os histogramas foram ajustados por uma Gaussiana dada por $a e^{-x^{2} / 2 \sigma^{2}}$ mostrada pela linha contínua. Os gráficos $\mathbf{a}, \mathbf{b}$ e $\mathbf{c}$ foram obtidos para frequência de $10 \mathrm{fps}$. a: deslocamento quadrático médio, MSD, por $\Delta t$; $\mathbf{b}$ : inclinação $\beta$ do MSD por $\Delta t$; c: histograma do $Z$, com parâmetros $a=10000$ e $\sigma=0.99$. Os gráficos d, e e f são similares aos a, $\mathbf{b}$ e $\mathbf{c}$, mas foram feitos com frequência de aquisição de imagem de $20 \mathrm{fps}$. Os valores dos parâmetros do histograma são $a=15400$ e $\sigma=0.98$. Os gráficos $\mathbf{g}, \mathbf{h}$ e i são similares aos a, b e c, mas foram feitos com frequência de aquisição de imagem de $30 \mathrm{fps}$. Os valores dos parâmetros do histograma são $a=21600$ e $\sigma=0.99$.

\section{Comportamento Geral}

Após realizadas as medidas experimentais, foram calculados os $Z \mathrm{~s}$ e os MSDs com suas inclinações $\beta$ s para cada Série descrita em Tab. 3.1. Os resultados para as microesferas ferrimagnéticas estão mostrados na Fig 3.2-2, e os resultados para as esferas de látex estão mostrados na Fig 3.2-3. 


\section{Difusão Anômala e a Dinâmica do Citoesqueleto}

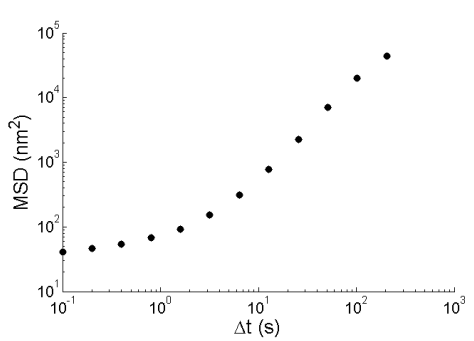

(a)

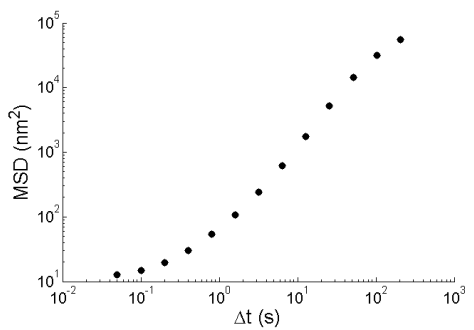

(d)

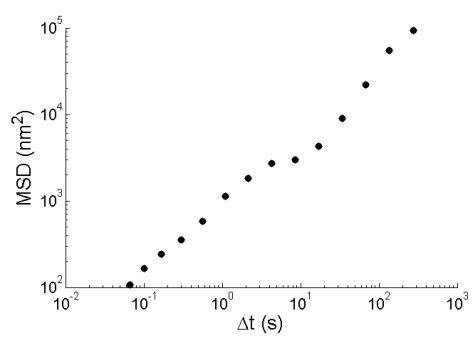

(g)

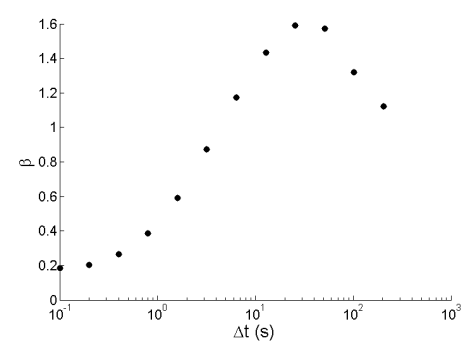

(b)

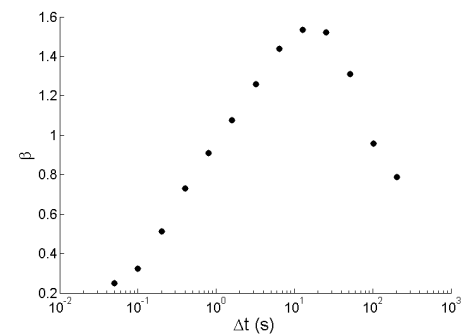

(e)

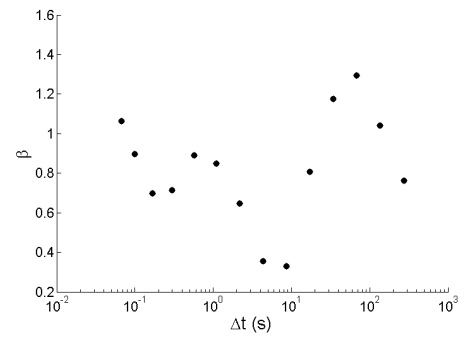

(h)

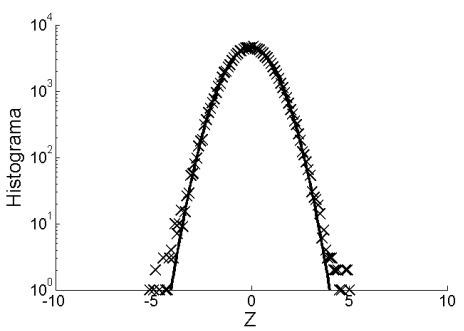

(c)

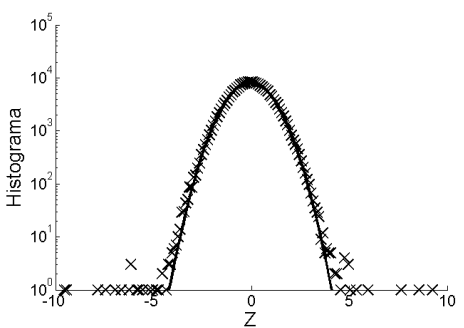

(f)

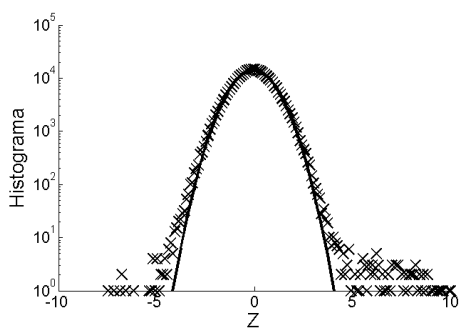

(i)

Figura 3.2-3. Experimentos com esferas de látex. Todos os gráficos foram feitos para $r$. Os histogramas foram ajustados por uma Gaussiana dada por $a e^{-x^{2} / 2 \sigma^{2}}$ mostrada pela linha contínua. Os gráficos a, b e c foram obtidos para frequência de $10 \mathrm{fps}$. a: deslocamento quadrático médio, $M S D$, por $\Delta t$; b: inclinação $\beta$ do MSD por $\Delta t$; c: histogramas de $Z$, com parâmetros $a=4590.0$ e $\sigma=0.99$. Os gráficos d, e e f são similares aos $\mathbf{a}, \mathbf{b}$ e c, mas foram feitos com frequência de aquisição de imagem de $20 \mathrm{fps}$. Os valores dos parâmetros do histograma são $a=8310.0$ e $\sigma=0.98$. Os gráficos $\mathbf{g}$, h e i são similares aos $\mathbf{a}, \mathbf{b}$ e c, mas foram feitos com frequência de aquisição de imagem de 30 fps. Os valores dos parâmetros do histograma são $a=14300$ e $\sigma=0.94$.

Olhando os MSDs, Fig. 3.2-2 a, d, g e Fig. 3.2-3 a, d, g, todos mantém um comportamento semelhante. Para pequenos $\Delta t$ s os MSDs mostram um regime subdifusivo, e para grandes $\Delta t$ s um regime superdifusivo, o que pode ser corroborado olhando as inclinações dos mesmos,

Fig. 3.2-2 b, e, h e Fig. 3.2-3 b, e, h.

Pode-se analisar também a tendência do MSD, e obter equações para pequenos e grandes $\Delta t$ s. Desta maneira, foram feitos ajustes para os primeiros e últimos pontos do gráfico da 


\section{Difusão Anômala e a Dinâmica do Citoesqueleto}

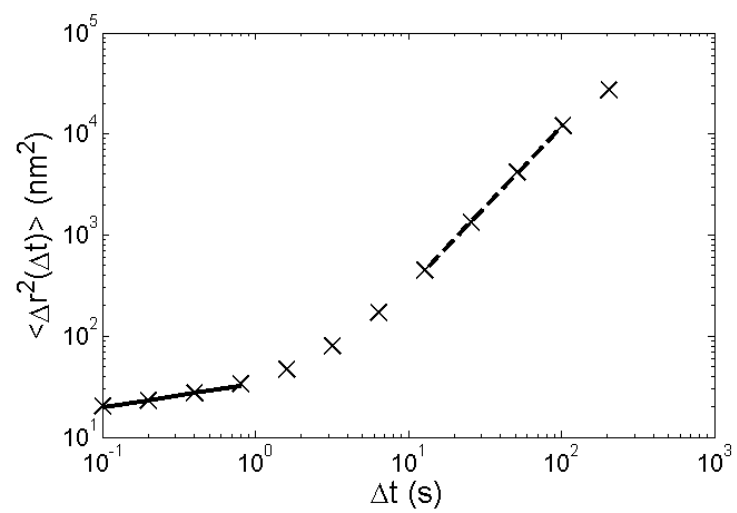

Figura 3.2-4. Ajuste do MSD da Fig. 3.2-3 a para pequenos e grandes $\Delta t$ 's. O ajuste foi baseado na equação $\left\langle\Delta r^{2}(\Delta t)\right\rangle=D^{*} \Delta t^{\beta}$, onde $\beta$ é a inclinação do MSD e $D^{*}$ seria um parâmetro relacionado ao coeficiente de difusão. Para a reta contínua e pontilhada foram encontrados os valores $(34.08 \pm 0.95)$ e $(7.68 \pm 0.38)$ para $D^{*}$ e os valores $(0.24 \pm 0.02)$ e $(1.59 \pm 0.01)$ para $\beta$ respectivamente.

Fig. 3.2-3 a. O ajuste foi baseado na equação $\left\langle\Delta r^{2}(\Delta t)\right\rangle=D^{*}\left(\Delta t / t_{0}\right)^{\beta}$, onde $\beta$ é a inclinação do MSD, $t_{0}$ é uma constante escolhida arbitrariamente como igual a $1 \mathrm{~s} \mathrm{e} D^{*}$ seria um parâmetro relacionado ao coeficiente de difusão, ver Fig. 3.2-4. Para a reta contínua e pontilhada foram encontrados os valores $(34.08 \pm 0.95)$ e $(7.68 \pm 0.38)$ para $D^{*}$ e os valores $(0.24 \pm 0.02)$ e $(1.59 \pm 0.01)$ para $\beta$ respectivamente.

Olhando os histogramas de $Z_{x}$ e $Z_{y}$ com seus ajustes Gaussianos, observa-se que para a partir de aproximadamente $|Z|>3$ há uma leve quebra do comportamento Gaussiano, Fig. 3.22 c, f, i e Fig. 3.2-3 c, f, i. Essa quebra indicaria a existência de algum processo que não é esperado pela teoria de Brown, ou seja, que não é gerado apenas por movimentação térmica.

\section{Dinâmica das Microesferas}

Escolhendo a trajetória de uma microesfera como exemplo, Fig. 3.2-5, pode-se observar que esta tem uma dinâmica intermitente, com períodos de saltos e períodos de confinamento, Fig. 3.2-5. Esse comportamento pode ser reforçado olhando para o MSD, Fig. 3.2-2 a, d, g e 3.2-3 a d, g: para pequenos $\Delta t$ s, o MSD tem um comportamento subdifusivo, enquanto que para grandes $\Delta t \mathrm{~s}$, o comportamento é superdifusivo. Esses regimes estariam relacionados res- 


\section{Difusão Anômala e a Dinâmica do Citoesqueleto}

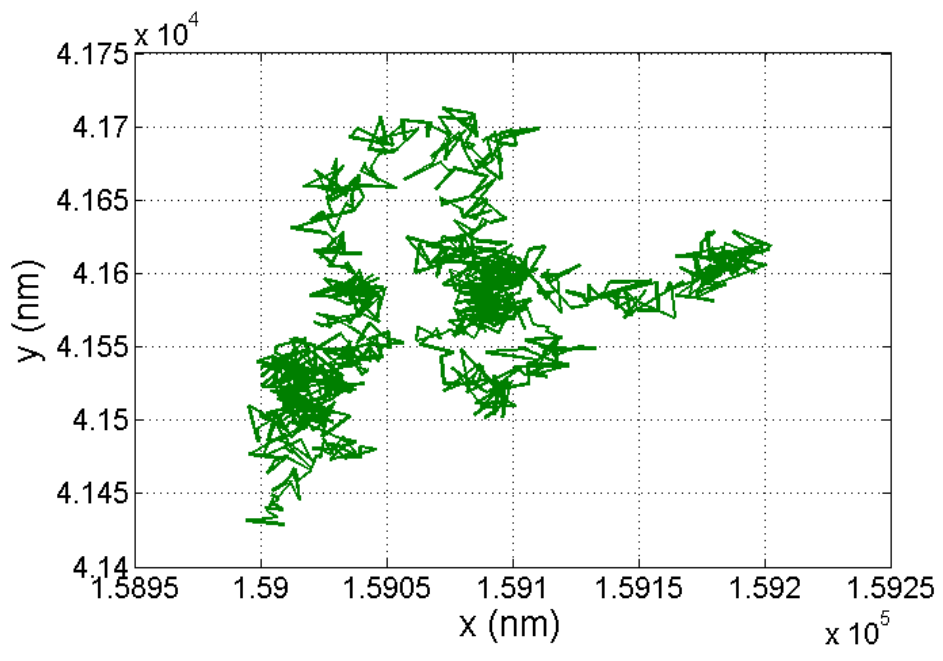

Figura 3.2-5. Movimentação de uma microesfera ligada ao CSK.

pectivamente aos períodos de confinamento e aos períodos de saltos [7].

Uma maneira de se explorar esse comportamento seria avaliando o que acontece nos instantes anteriores e posteriores dos saltos anômalos dados pelas microesferas. Dessa maneira foram feitos os seguintes passos:

1. primeiramente foram identificados entre quais instantes $t_{i}$ e $t_{i+1}$ da série temporal os saltos anômalos, $|Z| \geq 3$, ocorreram,

2. depois de identificados esses instantes, foram calculados os deslocamentos feitos pelas microesferas entre os instantes $t_{i+1}$ e $t_{i+1}+\Delta t$, e entre os instantes $t_{i}-\Delta t$ e $t_{i}$. Para esse estudo foram escolhidos $\Delta t=0.1,1$ e 10 segundos,

3. novas séries temporais das posições das microesferas foram geradas com os dados da série original, mas com frequência de $1 / \Delta t$. As mesmas foram normalizadas encontrando-se os $Z_{\Delta t} \mathrm{~s}$,

4. a partir daí, os deslocamentos encontrados, como descrito no item 2 , foram normalizados com os parâmetros referente às suas respectivas séries de $Z_{\Delta t}$, de acordo com a Eq.3.3. 


\section{Difusão Anômala e a Dinâmica do Citoesqueleto}

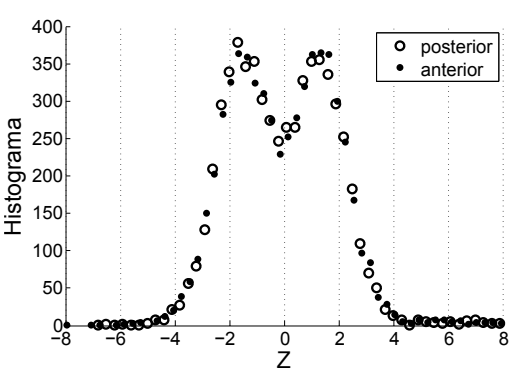

(a)

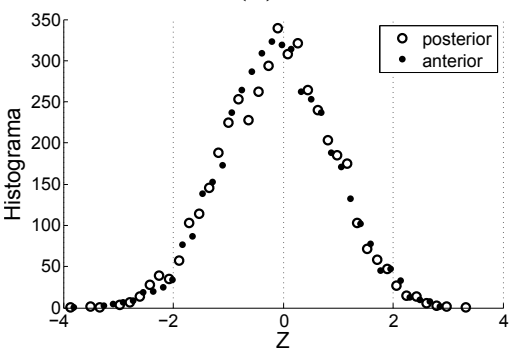

(d)

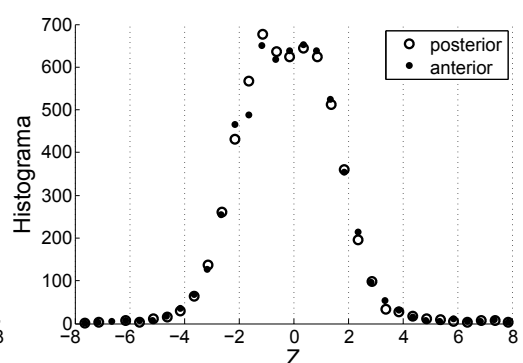

(b)

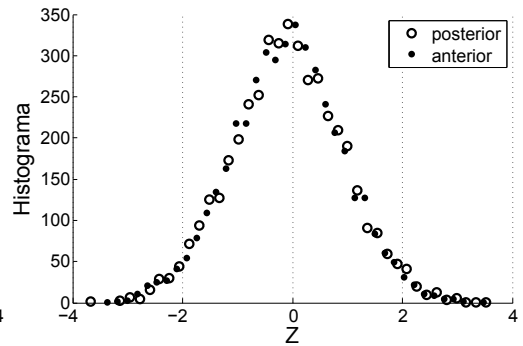

(e)

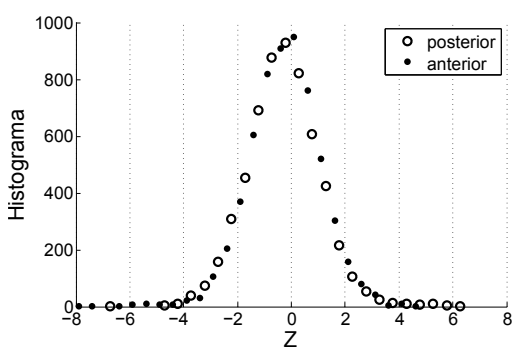

(c)

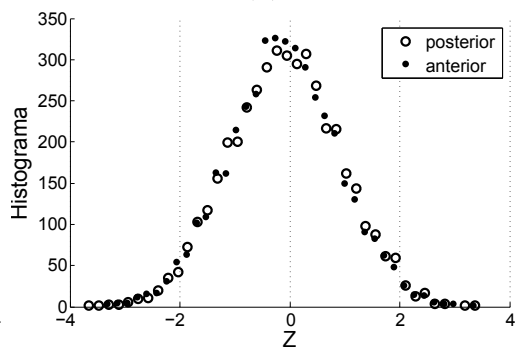

(f)

Figura 3.2-6. Histogramas dos $Z$ s referente ao tempo dos deslocamentos posteriores e anteriores a um salto anômalo onde $|Z| \geq 3$ : a) para $0.1 \mathrm{~s}, \mathrm{~b}$ ) para $1 \mathrm{~s} \mathrm{e} \mathrm{c)} \mathrm{para} 10 \mathrm{~s}$. Os histogramas foram feitos analisando todas as trajetórias de todas as microesferas de todos experimentos realizados neste capítulo. Esses histogramas experimentais foram comparados com trajetória Brownianas: d) para $0.1 \mathrm{~s}, \mathrm{e}$ ) para $1 \mathrm{~s} \mathrm{e} \mathrm{f)} \mathrm{para} 10 \mathrm{~s}$. Foram feitas 80 trajetórias com 20000 passos com intervalo de $0.1 \mathrm{~s}$.

No procedimento descrito acima, foram analisadas todas as trajetórias de todas as microesferas e experimentos realizados neste capítulo, ver Tab.3.1. Note que os deslocamentos entre os pontos $t_{i}$ e $t_{i+1}$ foram desconsiderados nos cálculos dos deslocamentos. Essa medida foi tomada para evitar possível tendência que esse ponto poderia causar, ficando apenas com os pontos que antecedem e precedem os saltos anômalos. Os resultados encontrados estão mostrados na Fig. 3.2-6.

A partir da Fig. 3.2-6 pode-se observar o comportamento dos deslocamentos anteriores e posteriores com o tempo. Na Fig. 3.2-6 a, pode-se observar dois picos no histograma. Esses picos mostram que os deslocamentos são maiores que a média, com valores típicos entre uma e duas vezes o desvio padrão. Também mostra que os saltos são agrupados. À medida que o tempo vai aumentando, esses picos vão se aproximando, ver Fig. 3.2-6 b, até que se encontram numa curva tipo Gaussiana com pico único, ver Fig. 3.2-6 c. Esse fenômeno está associado 


\section{Difusão Anômala e a Dinâmica do Citoesqueleto}

com a memória, ou seja, a partir de 10 s, não se tem mais memória do evento anômalo. Em contraste com o que ocorre num movimento totalmente aleatório, um movimento Browniano, essa memória é inexistente, como pode ser visto nas Figs. 3.2-6d, e e f. Para essas análises foram feitas 80 trajetórias Brownianas com 20 mil passos com intervalo de $0.1 \mathrm{~s}$.

Os histogramas mostrados nas Figs. 3.2-6a, b e c foram ajustados por duas Gaussianas, dadas por: $y=a_{0} e^{-\left(x-a_{1}\right)^{2} / 2 a_{2}^{2}}+a_{3} e^{-\left(x-a_{4}\right)^{2} / 2 a_{5}^{2}}$. Os parâmetros $a_{1}$ e $a_{4}$ representam o centro das Gaussianas referentes aos picos observados nos histogramas. Com o aumento do tempo, esses picos vão se movendo em direção de $Z=0$, e esses parâmetros vão se aproximando de zero. Os valores encontrados estão mostrados na Tab. 3.2.

\begin{tabular}{ccccccc}
\hline & $0.1 \mathrm{~s}$ & \multicolumn{3}{c}{$1 \mathrm{~s}$} & $\mathrm{~s}$ \\
\hline Parâmetros & Anterior & Posterior & Anterior & Posterior & Anterior & Posterior \\
\hline$a_{0}$ & 363.9 & 354.1 & 577.8 & 535.1 & 458.7 & 171.3 \\
$a_{1}$ & 1.4 & 1.3 & 0.8 & 0.9 & -0.1 & -0.2 \\
$a_{2}$ & 1.0 & 1.0 & 1.1 & 1.0 & 1.1 & 0.8 \\
$a_{3}$ & 358.7 & 367.3 & 502.1 & 590.2 & 497.2 & 762.0 \\
$a_{4}$ & -1.5 & -1.6 & -1.4 & -1.3 & -0.3 & -0.3 \\
$a_{5}$ & 1.0 & 0.9 & 1.1 & 1.1 & 1.4 & 1.3 \\
\hline \hline
\end{tabular}

Tabela 3.2. Parâmetros do ajuste de duas Gaussianas, como descrito no texto, dos histogramas mostrados nas Figs. 3.2-6 a, b e c.

Como foram calculados os deslocamentos anteriores e posteriores aos saltos, e não teve diferença entre eles, pode-se dizer que os mesmos não estava em situações diferentes. Uma situação diferente seria por exemplo o caso em que a microesfera estivesse confinada e saísse dessa situação após um salto anômalo, ou seja, um salto onde $|Z| \geq 3$. Neste caso, os histogramas dos deslocamentos posteriores e anteriores seriam diferentes, o que não ocorreu. Desta maneira, pode-se afirmar que os saltos anômalos são proeminentes nas áreas onde não ocorre confinamento, referentes ao período superdifusivo.

\section{$\underline{\text { Modelo }}$}




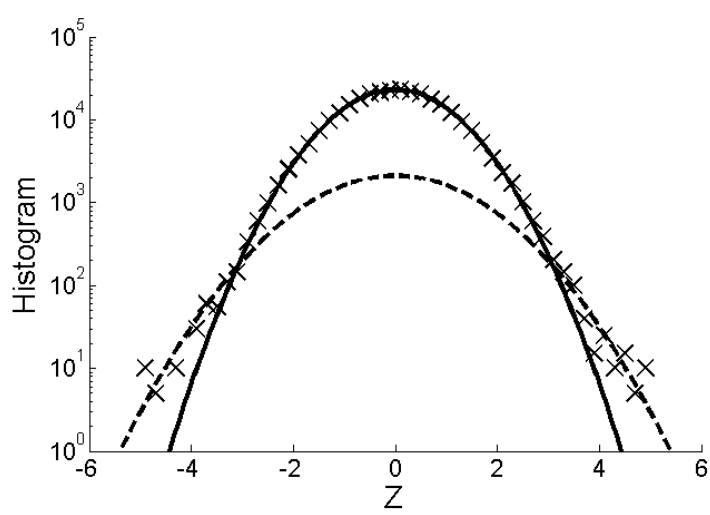

Figura 3.2-7. Modelando o movimento das esferas através de duas Gaussianas, dadas por $a e^{-x^{2} / 2 \sigma^{2}}$. Dados referentes a Fig. 3.2-3 c. Os parâmetros encontrados para o ajuste mostrado pela linha contínua são $a=$ 22900 e $\sigma=0.99$, e para a linha tracejada são $a=2100$ e $\sigma=1.38$.

Visto que os histogramas apresentam uma quebra do comportamento Gaussiano, pode-se supor que o movimento das esferas sejam gerados pela soma de dois tipos de movimentos: primeiro, o movimento aleatório do citoesqueleto de caráter Gaussiano, e segundo, um movimento gerado por algum fonte interna nas células. Uma maneira de se modelar esses movimentos seria usando duas Gaussianas como mostrado na Fig. 3.2-7, feito para o experimento com as microesferas de látex, Fig. 3.2-3 a. A Gaussiana em linha contínua indicaria o movimento aleatório, enquanto que a Gaussiana em linha tracejada indicaria o segundo tipo de movimento.

\section{$\underline{\text { Tipos de Microesferas }}$}

Foram utilizadas dois tipos de microesferas neste trabalho, e abaixo algumas diferenças e vantagens observadas.

A quebra do comportamento Gaussiano foi mais evidente nas esferas de látex, onde pode-se ver uma cauda mais robusta para as mesmas nos histogramas. Essa diferença pode vir do fato de as esferas de látex serem menores (diâmetro de $4.1 \mu \mathrm{m}$ para as ferrimagnéticas e $2.4 \mu \mathrm{m}$ para as de látex) e menos densas $\left(5.0 \mathrm{~g} / \mathrm{cm}^{3}\right.$ para as ferrimagnéticas e $1.055 \mathrm{~g} / \mathrm{cm}^{3}$ para as de látex). Desta maneira seria mais fácil das esferas de látex se locomoverem junto com o citoesqueleto, 


\section{Difusão Anômala e a Dinâmica do Citoesqueleto}

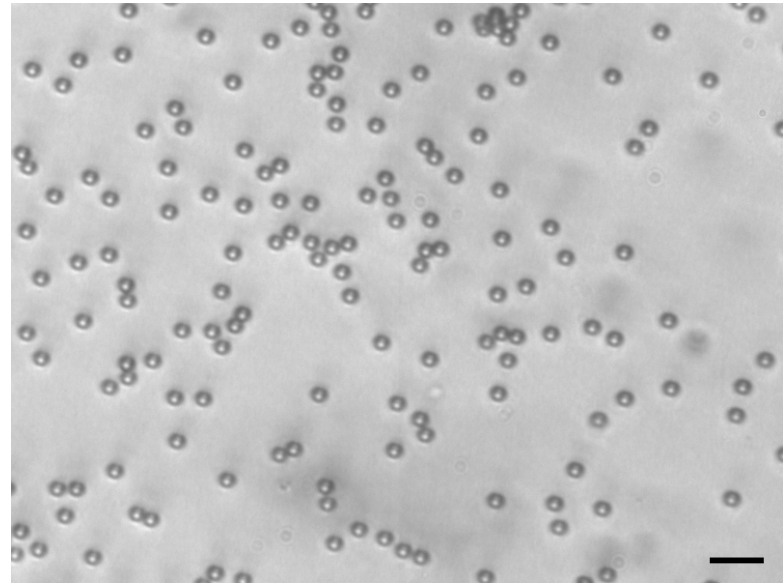

(a) Esferas de látex.

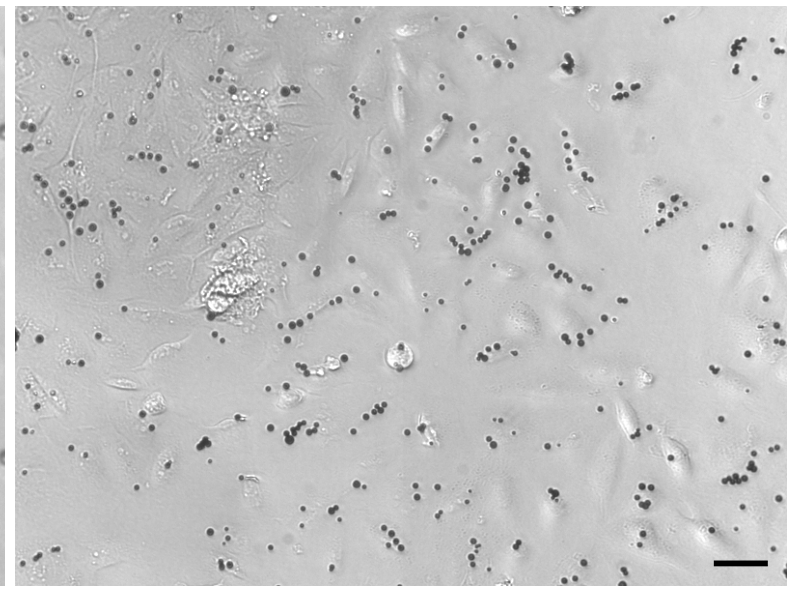

(b) Esferas ferrimagnéticas.

Figura 3.2-8. Imagens das microesferas de látex (magnificação de $40 \times$ ), barra igual a $10 \mu \mathrm{m}$, e ferrimagnéticas (magnificação de $10 \times$ ), barra igual a $40 \mu \mathrm{m}$.

ou seja, estas seriam mais sensíveis. Calculando a força peso dessas microesferas, obtêm-se $P_{\text {lat }}=74.8 \mathrm{pN}$ e $P_{\mathrm{mag}}=1.8 \mathrm{nN}$, enquanto que a força exercida por uma fibra de estresse conectada a uma adesão focal é $5.5 \pm 2 \mathrm{nN}$ [39]. Esta força seria a força que estaria agindo nas microesferas, desta maneira, a massa das microesferas de látex pode ser negligenciada, mas a da ferrimagnética não, mostrando que essa esfera pode impactar nas medições de difusão anômala.

Embora as esferas de látex tenham gerado resultados melhores, não serão utilizadas no restante do trabalho. O motivo para tal é o fato de que as microesferas ferrimagnéticas são opacas enquanto as de látex não, ver Fig. 3.2-8. O software usado para a identificação das microesferas foi desenvolvido para encontrar o centro de massa de uma esfera, mas este não é capaz de identificar o formato de toróide gerado pelas microesferas de látex. Assim, para a realização do experimento foi necessário desfocar levemente a imagem para o software fazer a identificação. Assim, optamos em não continuar com esse procedimento e utilizar apenas as ferrimagnéticas.

O diâmetro das microesferas também tem influência em relação ao ruído na medida. Esse assunto será comentado mais adiante. 


\section{Difusão Anômala e a Dinâmica do Citoesqueleto}

\section{Frequência de Aquisição}

Uma maneira de evidenciar a cauda dos histogramas seria fazer experimentos com frequência de captura de imagens maior que a atual. A hipótese seria que a movimentação ativa é rápida, e uma janela temporal grande incluiria mais movimentação térmica que ativa, mascarando os saltos anômalos. Essa suposição vem de fundamentos biológicos: a tensão que os filamentos de actina apresentam vem dos crosslinks com miosina; essas ligações acto-miosinas estão sujeitas a flutuações e eventualmente se rompem. O tempo de reação de uma proteína que se rompe de uma ligação dessas mudando de conformação é da ordem de nanosegundos [40]. Então espera-se que esses movimentos observados sejam rápidos, e que aumentando a frequência de aquisição, estes possam ser evidenciados. Desta maneira, foram repetidos os experimentos com 10 fps para frequências de 20 e 30 fps.

Como esperado, é possível observar melhor a cauda para experimentos com maiores frequências. Não houve uma diminuição significativa do desvio, mas surgiram mais pontos fora do comportamento Gaussiano.

Para os experimentos com esferas ferrimagnéticas, houve pouca diferença com o de $10 \mathrm{fps}$ mas mesmo assim, a cauda dos histogramas fica uma pouco mais evidente. Já para os experimentos realizados com as esferas de látex obtemos diferenças visualmente significantes aumentando a frequência de aquisição de imagem.

Para 30 fps mais oscilações são percebidas no MSD feito com as esferas de látex. Isso vem do fato de que agora temos muito mais imagens, ficando evidente detalhes que não poderiam ser vistos antes. Podemos dizer que essas características assemelham-se a Fig. 1.1-2, onde as oscilações representariam trocas de períodos onde as esferas estariam presas ou se movimentando junto com o citoesqueleto.

\section{Magnificação e Ruído}




\section{Difusão Anômala e a Dinâmica do Citoesqueleto}

Outra observação importante a se fazer é acerca da magnificação usada. Para os experimentos com as microesferas ferrimagnéticas foi utilizada magnificação de $10 \times$ e para os experimentos com látex foi utilizada magnificação de $40 \times$. Quanto maior a magnificação, menor a relação ruído/sinal, ver Apêndice E. Pela calibração da câmera, ver Apêndice G, pode-se calcular que as microesferas ferrimagnéticas são gravadas com diâmetro em torno de 5.6 pixels, enquanto que as de látex com 13.3 pixels, resultando em um erro menor para o maior diâmetro, o que melhoraria a medida. Para checar isso, foram escolhidas cinco microesferas de maneira aleatória para dois casos, primeiro com esferas de látex, e depois para esferas ferrimagnéticas. Essas microesferas foram recortadas das imagens originais e analisadas da seguinte maneira: a) foram identificados os pixels que apresentavam valor acima de um limiar, no caso 170, b) contabilizados quantos pixels apresentam a condição descrita em a), c) este valor é igual a área $A$ em pixel $^{2}$ aproximada da esfera que é considerada para o cálculo do centro de massa pelo software, ver Ap. E, d) $A=\pi r^{2}$, onde $r$ é o raio efetivo da esfera, e) a partir do raio efetivo encontrado, pode-se calcular o erro referente, ver Eq. E.3. Os valores encontrados para os raios efetivos e os erros foram: $r=3.2 \pm 0.2$ e $E=2.3 \pm 0.4$ para as esferas ferrimagnéticas e $r=10.2 \pm 0.5$ e $E=0.6 \pm 0.1$ para as esferas de látex. Para as esferas ferrimagnéticas, o erro encontrado é maior, aproximadamente metade do valor do raio real. Este resultado demonstra a importância de conhecer o sistema em que se está trabalhando, ou seja, conhecer os detalhes experimentais, tanto quanto softwares de análise envolvidos no processo.

\section{$\underline{\text { Tipo Celular }}$}

As células utilizadas aqui foram células epiteliais, que são mais estáveis, e com pouca atividade contrátil. Diferente de células de músculo, especializadas em contração e por isso são muito mais ativas. A velocidade in vivo da miosina responsável pela contração em músculos liso é $v=250 \mathrm{~nm} / \mathrm{s}$ [40], com passos de 5-10 nm [40,41], oque está de acordo com a ordem de grandeza dos deslocamentos e distância total do movimento das microesferas, ver 


\section{Difusão Anômala e a Dinâmica do Citoesqueleto}

Fig. 3.2-5. Esse mesmo tipo de miosina também é encontrada nas células epiteliais [40]. Por exemplo, olhando o caminho de duas microesferas, uma ferrimagnética e outra de látex, para frequência de $10 \mathrm{fps}$, encontra-se que o deslocamento (posição final menos a inicial) para 1000 frames é da ordem de 50 a $100 \mathrm{~nm}$ para as ferrimagnéticas e 250 a $350 \mathrm{~nm}$ para as de látex. Já o deslocamento total (soma de todos os deslocamentos) é da ordem de 6 a $8 \cdot 10^{3} \mathrm{~nm}$ para as ferrimagnéticas e 1 a $2 \cdot 10^{4} \mathrm{~nm}$ para as de látex.

\section{Próximos Capítulos}

Neste capítulo foram introduzidas características observadas da dinâmica do CSK e fatores que influenciariam na aquisição de dados. Além do mostrado nesse capítulo, existem outras características a serem exploradas e perguntas a serem feitas. Por exemplo: qual a origem dos saltos anômalos? Estes apresentam correlação temporal, ou espacial para ocorrer? Essas

correlações se assemelham a algum fenômeno existente? É possível evidenciar esses saltos com frequências mais altas? Os próximos Capítulos foram escritos tentando responder a essas questões, e também propor uma modelagem teórica desse comportamento. 


\section{Capítulo 4}

\section{A Dinâmica do Citoesqueleto e Abalos}

\section{Sísmicos}

A analogia entre sistemas biológicos e abalos sísmicos não é nova. Ansari et al. [42] usou o termo proteinquake para explicar as grandes e repentinas reconfigurações da molécula de mioglobina [42], uma proteína armazenadora de oxigênio encontrada em abundância no músculo esquelético de vertebrados, e que pode se ligar e desligar a ligantes como $\mathrm{O}_{2}$ e $\mathrm{CO}$, implicando a existência de um grande número de subestados configuracionais (CS) [42,43]. O movimento entre subestados de equilíbrio foram definidos como proteins-equilibrium fluctuations (EF), enquanto movimentos entre estados e estados intermediários de não equilíbrio foram definidos como functionally important motions (FIMs). Em EFs, as flutuações na energia interna e na entropia podem ser determinadas pela mecânica estatística do equilíbrio, por outro lado, FIMs requerem excitação da proteína, a qual pode ser gerada por fotodissociação, por exemplo. A energia de deformação (strain energy) repentinamente liberada durante o retorno da molécula ao equilíbrio é dissipada em forma de ondas de deformação que propaga por ela [42]. Daí a analogia entre proteinquake e abalos sísmicos. 


\section{A Dinâmica do Citoesqueleto e Abalos Sísmicos}

O citoesqueleto (CSK) em repouso metaboliza trifosfato de adenosina (ATP) a uma taxa basal, sendo portanto um sistema fora do equilíbrio [7]. Previamente foi sugerido que o CSK pode ter um grande número de subestados configuracionais definidos por um rugged free-energy landascape [19]. A rugosidade dessa energia é imaginada como originada de interações de curto alcance que formam barreiras e armadilhas. Foi definido como um subsestado qualquer grupo de barreiras localmente conectadas na landscape energy com uma energia da ordem de $k_{B} T$ ou menor. Então, o CSK pode pular entre subestados através de agitação térmica. Entretanto, quando barreiras são substancialmente maiores que $k_{B} T$, o CSK pode ficar aprisionado. Mas para ultrapassar a barreira, escapar da armadilha, e pular para outro estado, o CSK pode usar energia liberada da hidrólise do ATP, que é em torno de 20-25 $k_{B} T$ [7].

Rugged energy landscapes são descritos para materiais fora do equilíbrio, como vidros, fazendo com que tais sistemas tenham uma linguagem unificada [43]. Relaxações estruturais irreversíveis num vidro são caracterizadas por heterogeneidade dinâmica e cooperatividade [44-46]. De fato, o CSK de células aderentes exibem características vítreas, as quais incluem rearranjos estruturais que são intermitentes, não Gaussianos e cooperativos [7]. Neste contexto, um estudo recente de desdobramento de molécula de proteína enfatiza que eventos sequenciais são discretos e independentes, como num processo Markoviano [47]. Mas se transições entre estados da proteína são cooperativos em vez de Markovianos, é possível que a metáfora com comportamento de abalo sísmico seja mais profunda que imaginado anteriormente? Em relação ao CSK esta noção não é sem base plausível. A célula aderente gera forças contráteis dependentes de ATP que são transmitidas a lugares remotos ao longo das fibras de estresse, que se expandem pela célula [48]. Essas forças contráteis levam ao armazenamento de energia elástica (strain) nos subfragmentos S2 do motor de miosina, nos filamentos de actina e no substrato elástico no qual a célula se adere. E como essa energia elástica pode se armazenar em vários compartimentos celulares, é possível que pelo menos alguma parte da energia possa ser liberada numa sequência de eventos descontínuos mas cooperativos de maneira similar a 


\section{A Dinâmica do Citoesqueleto e Abalos Sísmicos}

ondas sísmicas na crosta da Terra. Aqui testar-se-á essa idéia.

Os abalos sísmicos são governados principalmente por três lei empíricas: (i) a distribuição espacial de clusters seguem falhas hierárquicas estruturais [49]; (ii) lei de Gutenberg-Richter: sobre um intervalo de tempo fixo, o número de abalos sísmicos numa dada região, com energia que excede algum referencial de energia, segue uma lei de potência dada por $M^{-B}$; (iii) lei de Omori: a taxa de choques posteriores $n(t)$, isto é, o número por unidade de tempo, também segue uma lei de potência $n(t)=b t^{-a}$. Para o estudo de ondas sísmicas na Terra, uma sonda é colocada na superfície da Terra e medido o seu deslocamento. Para estudar eventos análogos em células, se houver, microesferas são ligadas em sua superfície, e aderidas ao CSK, enquanto seus nano movimentos espontâneos são observados. Assim, a intenção é demostrar que os rearranjos estruturais de nano escala do CSK de células de músculo liso de vias aéreas seguem essas mesmas três leis como os abalos sísmicos.

\subsection{Métodos}

Para calcular-se os eventos de remodelamento em nano escala na ausência de movimento e aglomeração celular, as células foram dispostas individualmente num substrato definido enquanto a posição das microesferas ligadas às células foram rastreadas [50]. Foram usadas membrane-based micro-patterning (MEMPAT) de $15 \mu \mathrm{m}$ para dispor a célula em uma ilha quadrada, Fig. 4.1-1 (a). Cada célula foi colocada num quadrado de $50 \mu \mathrm{m}^{2}$, o qual foi escolhido baseado na área média de uma célula de músculo liso de vias aéreas humanas, ver Ref. [50] para mais detalhes. Os dados experimentais obtidos são os mesmos usados na Ref. [7]. Aqui serão analisados os dados teoricamente.

Para explorar a superfície das células, esferas ferrimagnéticas (4.1 $\mu \mathrm{m}$ de diâmetro) foram 
(a)
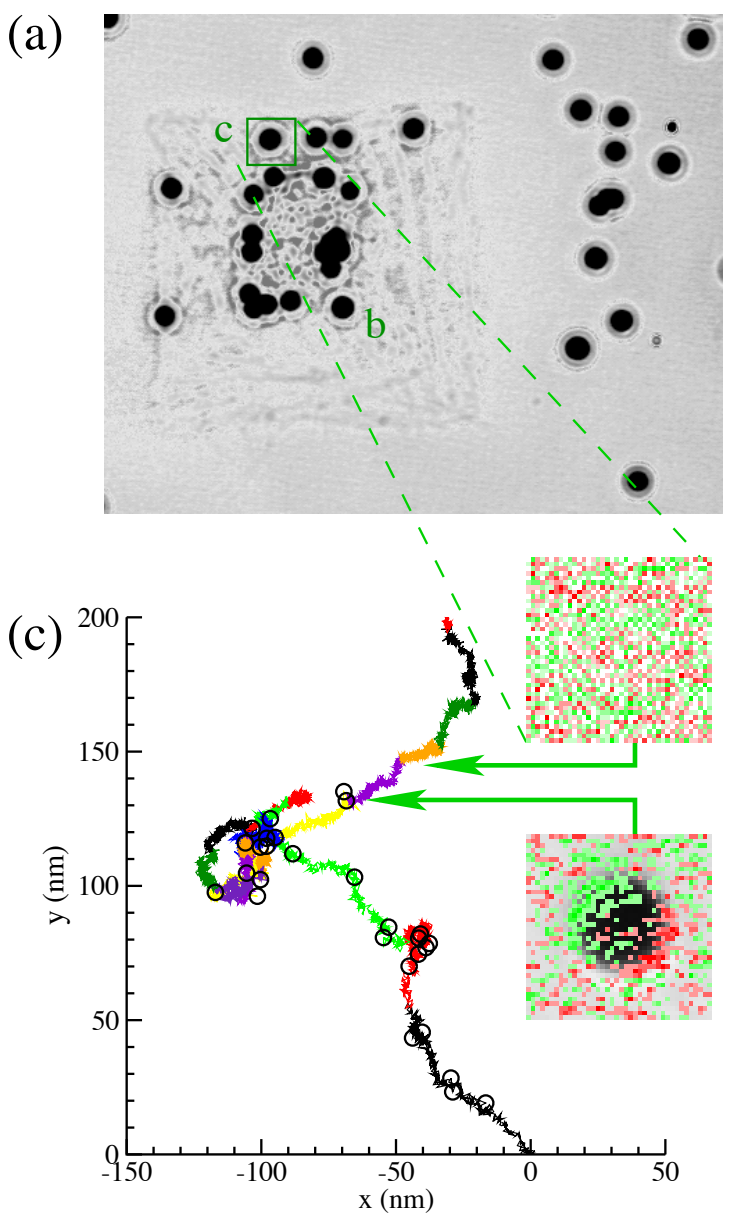

(b)

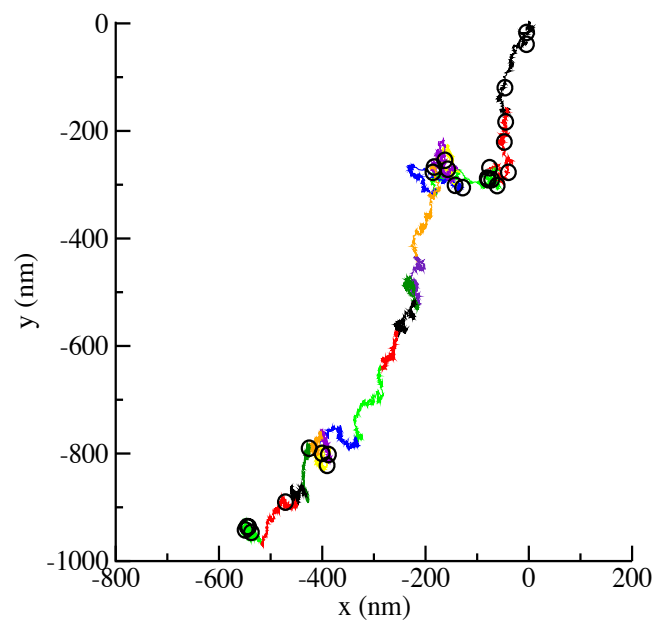

(d)

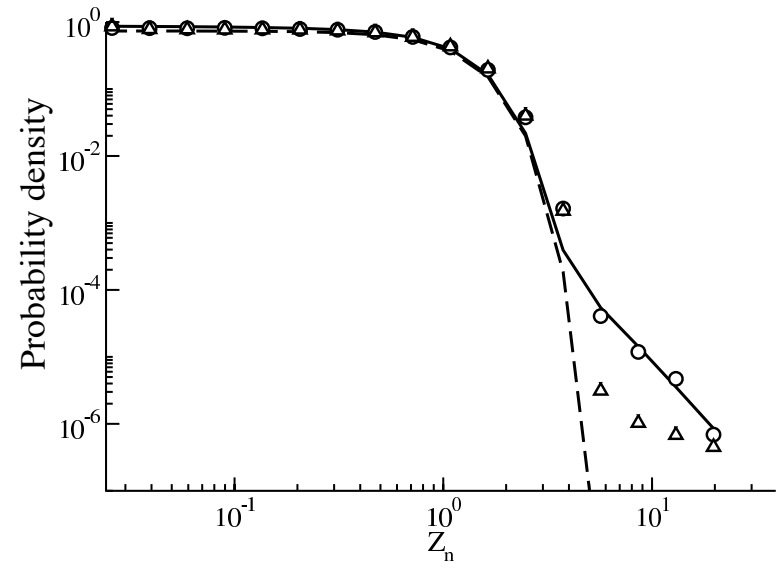

Figura 4.1-1. (a) Microesferas anexadas em célula do músculo liso de vias aéreas humanas micro-patterned onde foram rastreadas usando imagens de $12 \mathrm{~Hz}$ gravadas em câmara CCD acoplada a um microscópio invertido. (b,c) Dez minutos de trajetória da esfera. Cada cor representa 40 segundos de trajetória. Círculos na trajetória indica valores de $Z_{n}>3$. Em (c), as inserções são imagens originalmente de (a) as quais foram digitalmente processadas para ressaltar diferenças entre imagens consecutivas. A cor vermelha indica a redução do nível de escala de cinza da imagem enquanto que verde indica um aumento. A imagem acima mostra flutuação típica da escala de cinza na posição ocupada por uma microesfera, setas em (a). A imagem inferior mostra um cytoquake, note que a sombra vermelha-verde na imagem superimposta do bead indica um movimento rápido na direção nordeste. Os círculos abertos no gráfico acima mostra os 30 maiores saltos nesta série, todos eles com $Z_{n}>3$. (d) Histograma dos deslocamentos da microesfera normalizados $Z_{n}$ (círculo cheio) num gráfico log-log. A linha contínua mostra o melhor ajuste usando $P\left(Z_{n}\right)=B e^{-Z_{n}^{2} / \beta}+A\left(Z_{n}+Z_{\mathrm{G}}\right)^{-\alpha}, \operatorname{com} B=0.79, \beta=1.80, A=0.05, Z_{G}=0.87$ e $\alpha=3.62$. A linha pontilhada mostra um ajuste Gaussiano, e os triângulos é com ATP depletado. O gráfico mostra duas regiões: a primeira região, para pequenos $Z_{n}$ onde o histograma segue uma distribuição Gaussiana (linha pontilhada), associada com movimento térmico; e a segunda região, a cauda do gráfico, a qual segue uma lei de potência. 


\section{A Dinâmica do Citoesqueleto e Abalos Sísmicos}

cobertas com um peptídeo sintético contendo a sequência ArgGlyAsp (RGD) e aderidas à superfície apical da célula. Essas esferas se aderem fortemente a F-actina através de receptores de integrina transmembrânico, principalmente $\alpha_{5} \beta_{1}$ [51,52]. Os movimentos espontâneos das esferas foram então monitorados, durante uma média de 400 s, usando um algoritmo que calcula o centro de massa das microesferas de imagens gravadas por uma câmara CCD.

Posições $\vec{r}_{n}$ ao longo de cada trajetória foram medidas a 12 fps e os deslocamentos $d_{n}$ foram calculados como distância Euclidiana entre pontos sequenciais, $d_{n}=\left|\vec{r}_{n}-\vec{r}_{n-1}\right|$. Estes são normalizados pelo desvio padrão dos deslocamentos, $Z_{n}=d_{n} / \sigma$, onde $\sigma^{2}=\left\langle d^{2}\right\rangle-\langle d\rangle^{2}$, e $\langle$. denota média sobre cada trajetória.

Aqui é definido um cytoquake quando um deslocamento normalizado satisfaz $Z_{n}>Z_{\mathrm{M}}$, onde $Z_{\mathrm{M}}$ é um valor limiar que denota um tremor principal. Choques posteriores são definidos para deslocamentos subsequentes que satisfazem $Z_{\mathrm{A}}<Z_{n}<Z_{\mathrm{M}}$, onde $Z_{\mathrm{A}}$ é um limiar de evento secundário. Se um deslocamento subsequente excede $Z_{\mathrm{M}}$, este é tomado sendo um novo cytoquake (isto é análogo a Lei de Omori, mas com um limiar fixo para determinar a presença de um tremor principal). Trajetórias típicas de duas microesferas são mostradas na Fig. 4.1-1 b e 4.1-1 c. A cor dos traços muda a cada 40 s para maior clareza na visualização do movimento da microesfera. Eventos com $Z_{n}>Z_{\mathrm{M}}=3$ são indicados por círculos. $\mathrm{O}$ número cumulativo de ocorrências de choques posteriores $N_{\mathrm{A}}(t)$ seguintes a um cytoquake depende do limiar $Z_{\mathrm{M}}$, e para algum dado $Z_{\mathrm{M}}, N_{\mathrm{A}}(t)$ pode ser calculado. Estes dados podem ser comparados com o número cumulativo de choques posteriores preditos da integração da equação de Omori, $N_{\text {Omori }}(t)=b(1-a)^{-1} t^{1-a}$.

Em adição à medida de $N(t)$, e computando $N_{\text {Omori }}(t)$, foi também calculada a probabilidade cumulativa de ocorrência de pelo menos um choque posterior como uma função do tempo seguido de um cytoquake, baseado num modelo de chegadas aleatórias dadas por um processo de Poisson com intensidade $\lambda$. A probabilidade de exatamente $n$ ocorrências no tempo $t$ é 


\section{A Dinâmica do Citoesqueleto e Abalos Sísmicos}

dada por $p(t, n)=(\lambda t)^{n} e^{-\lambda t} / n$ !, e então a probabilidade de pelo menos um choque posterior é simplesmente

$$
P=1-e^{-\lambda t}
$$

Estas probabilidades foram comparadas com aquelas obtidas dos dados, calculados como segue. O número total $N$ de eventos $Z_{n}$ é maior comparado com o número $N_{\mathrm{A}}$ de ocorrências de choques posteriores $Z_{A}$ e o número do tremor principal $N_{\mathrm{M}}$. Então, a probabilidade de ter um cytoquake é $p=\left(N_{\mathrm{A}}+N_{\mathrm{M}}\right) / N$, e pode-se trocar $\lambda \approx N p$ na Eq.4.1, e usar isso para comparar com os dados experimentais.

\subsection{Resultados e Discussão}

Os deslocamentos das esferas mostram grandes saltos $\left(Z_{\mathrm{n}}>5\right)$ indicados por círculos, Fig. 4.11 b e 4.1-1c. Estes saltos foram aglomerados em espaço e tempo, como quantificado abaixo. O histograma de $Z_{n}$ revelou dois regimes. Para pequenos $Z_{n}$, a distribuição de probabilidade pode ser ajustada por uma Gaussiana (linha pontilhada, Fig. 4.1-1d). Esse movimentos são associados com flutuações térmicas do citoesqueleto. Para grandes $Z_{n}$ entretanto, a distribuição se afasta de Gaussiana e se aproxima a uma distribuição de lei de potência, $P(Z) \propto Z^{-\alpha}$. Esses grandes movimentos são associados com flutuações fora do equilíbrio. Estes resultados e conclusões são consoantes àqueles primeiros reportados em células por Bursac et al. [7]. Resultados similares foram subsequentemente confirmados em redes reconstituídas [53,54].

A Fig. 4.2-2 mostra o número médio de eventos de choques posteriores $\left\langle N_{\mathrm{A}}(t)\right\rangle$ para células a $24^{\circ} \mathrm{C}$ usando dois valores de $Z_{\mathrm{M}}$ : (topo) mostra dados para $Z_{\mathrm{M}}=5$, e para três limiares de choques posteriores, $Z_{\mathrm{A}}=3,3.5$ e 4 . (abaixo) mostra dados para $Z_{\mathrm{M}}=4$ e para três outros valores de choques posteriores, $Z_{\mathrm{A}}=2,2.5$ e 3 . Mostrados como linhas pontilhadas são os 


\section{A Dinâmica do Citoesqueleto e Abalos Sísmicos}
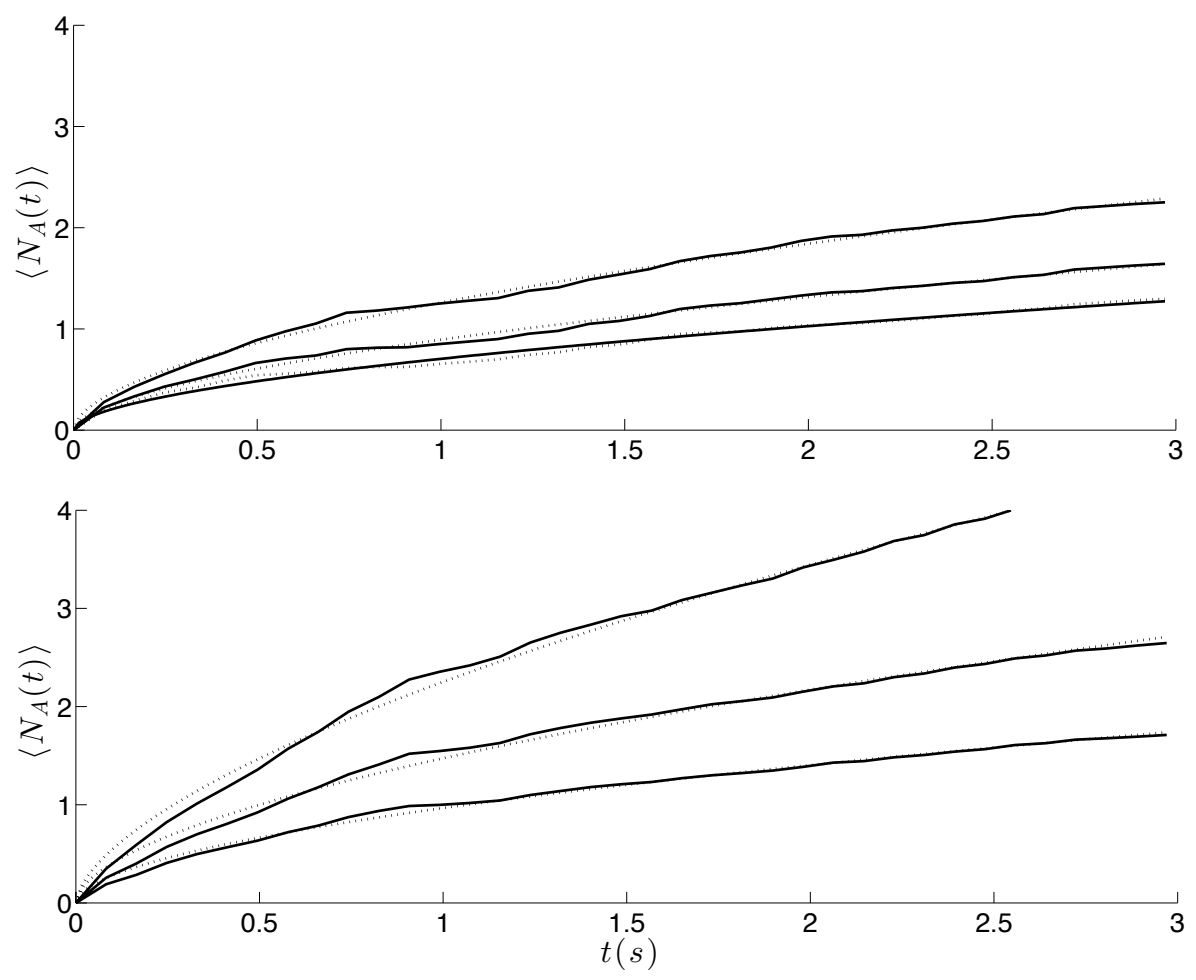

Figura 4.2-2. $\mathrm{O}$ número cumulativo $\left\langle N_{\mathrm{A}}(t)\right\rangle$ de saltos $Z_{n}$ maiores que um limiar $Z_{\mathrm{A}}$ para um dado trigger inicial $Z_{\mathrm{M}}$. Acima, o trigger inicial foi $Z_{\mathrm{M}}=5$. De cima para baixo as curvas contínuas foram calculadas para $Z_{\mathrm{A}}=3,3.5$ e 4 respectivamente. As linhas pontilhadas são o melhor ajuste da Eq. 4.2, e os parâmetros encontrados foram $0.45,0.44$ e 0.45 respectivamente. Abaixo, o trigger inicial foi $Z_{\mathrm{M}}=4$. De cima para baixo as curvas contínuas foram calculadas para $Z_{\mathrm{A}}=2,2.5$ e 3 respectivamente. As linhas pontilhadas são o melhor ajuste da Eq. 4.2, e os parâmetros encontrados foram 0.39, 0.41 e 0.46 respectivamente.

números cumulativos de choques posteriores da equação de Omori, com seus parâmetros $a$ e $b$ determinados por mínimos quadrados.

Foram comparadas predições para um processo de Poisson (Eq.4.1) com os dados experimentais das células a $24^{\circ} \mathrm{C}$, ruído térmico das microesferas grudadas no substrato, e para células com ATP depletado, Figs. 4.2-3a, b e c. Para cada uma dessas situações, foram utilizados três valores críticos, $Z_{\mathrm{C}}$, de $Z_{\mathrm{C}}=1$ (vermelho), 2 (verde) and 3 (azul). Os pontos são os valores médios de 23, 27 e 18 experimentos respectivamente e as barras são os erros padrões (SE).

Foi medido o número cumulativo de eventos $N(t)$ maiores que um dado limiar $Z_{\mathrm{C}}$ a partir de um salto inicial de $Z_{n}>Z_{\mathrm{M}}$; foi calculado para 15 a 25 microesferas por experimento em 
A Dinâmica do Citoesqueleto e Abalos Sísmicos

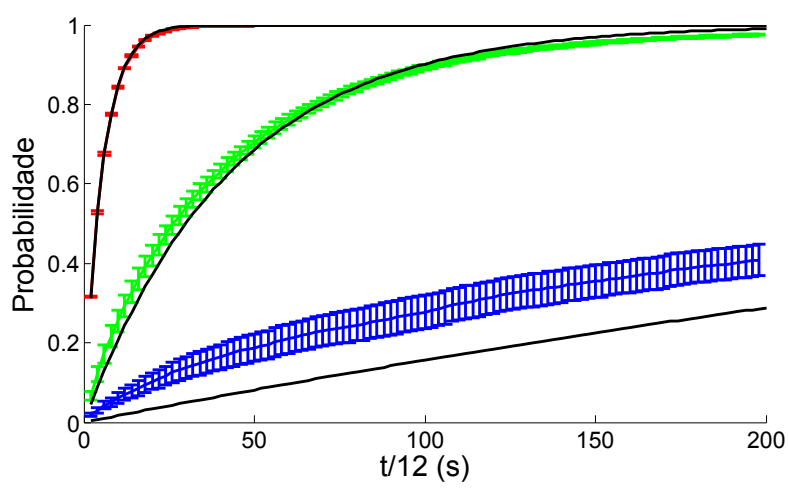

(a)

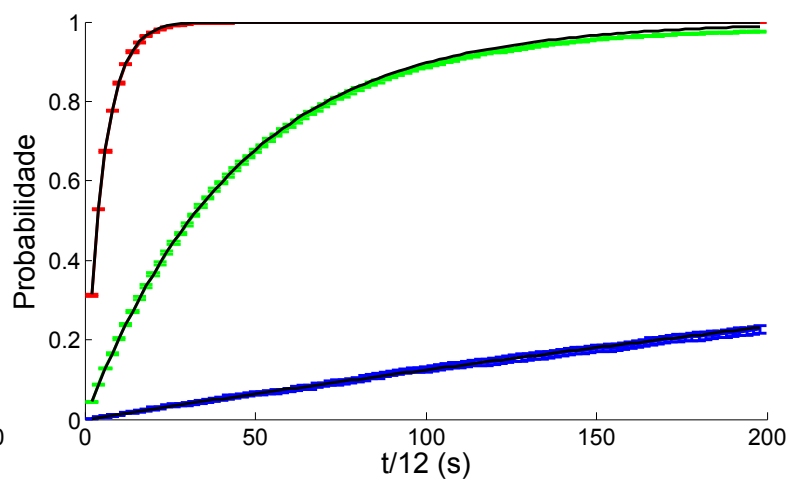

(b)

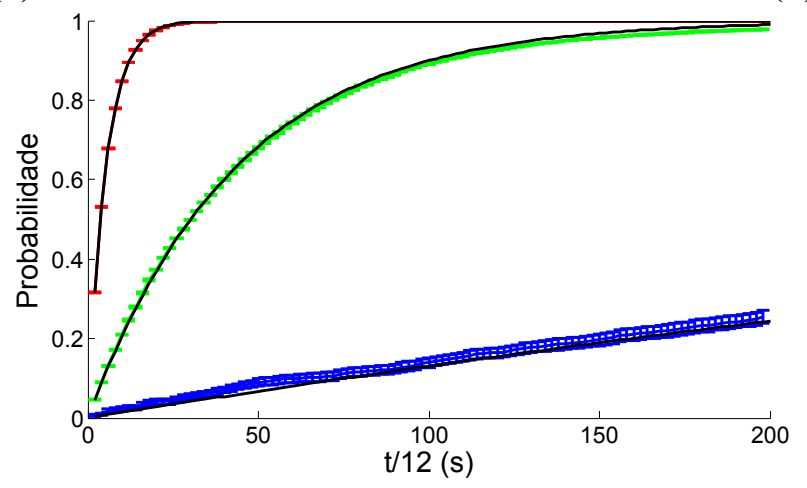

(c)

Figura 4.2-3. Dado um grande evento, $Z_{n} \geq Z_{\mathrm{C}}$, a probabilidade ( $\pm \mathrm{SE}$ ) de ter pelo menos um salto maior que $Z_{\mathrm{C}}$ com uma janela temporal de $t$, para $Z_{\mathrm{C}}=1$ (vermelho), $Z_{\mathrm{C}}=2$ (verde) and $Z_{\mathrm{C}}=3$ (azul). O erro foi calculado a partir de todos dados coletados. Linhas contínuas em preto foram preditas pela distribuição de Poisson de acordo com a Eq. 4.1. (a) Células a $24^{\circ} \mathrm{C}, \lambda=0.187 \pm 0.006,0.023 \pm 0.001$ e $0.0017 \pm 0,0002$ (b) ruído das microesferas grudadas ao substrato, $\lambda=0,189 \pm 0,005,0.023 \pm 0.001$ e $0.0013 \pm 0.0001 \mathrm{e}$ (c) células com ATP depletado, $\lambda=0.189 \pm 0.002,0.023 \pm 0.001$ e $0.0014 \pm 0.0001$.

23 experimentos (Fig. 4.2-2). A medida que $Z_{\mathrm{C}}$ diminui, $N(t)$ aumenta, e isso é verdade para $Z_{\mathrm{M}}=4$ and 5. Dado um grande evento, a probabilidade $( \pm \mathrm{SE})$ de ter pelo menos um salto adicional maior que $Z_{\mathrm{C}}$ com uma janela temporal de $t$ é mostrado na Fig. 4.2-3.

Foi feita a correlação temporal entre grandes eventos usando dois métodos. Primeiro, foi calculada a probabilidade de ter saltos subsequentes depois de um trigger, $Z_{n}>Z_{\mathrm{M}}$. Da lei de Omori, o número cumulativo de aftershocks é dado por [55],

$$
N_{\text {Omori }}(t)=b \frac{t^{1-a}}{1-a}
$$




\section{A Dinâmica do Citoesqueleto e Abalos Sísmicos}

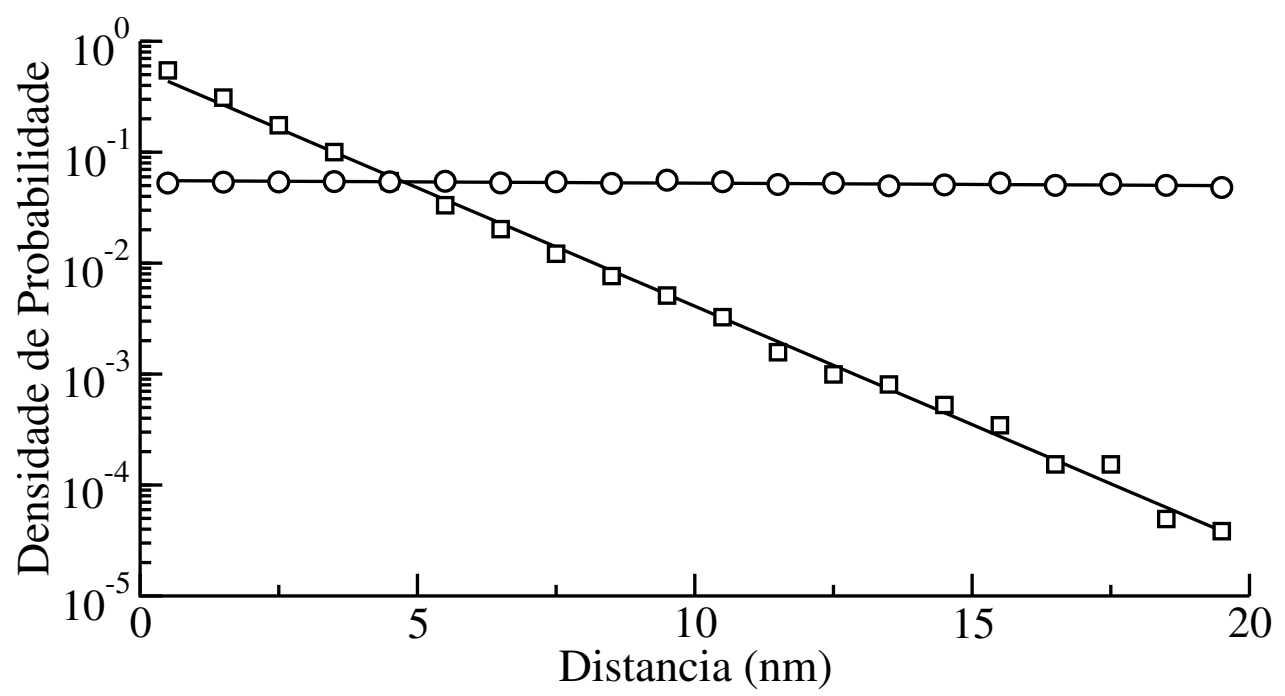

Figura 4.2-4. Densidades de probabilidade das distâncias entre pontos onde $Z_{n} \geq 3$ para experimentos de células a $24^{\circ} \mathrm{C}$ (quadrados) e para simulações de movimento Browniano (círculos). As linhas contínuas é o ajuste exponencial dos dados, com expoente -0.5 e 0.0 respectivamente. Na simulação foi utilizada uma distribuição Gaussiana com média zero e desvio $S D=6.07 \mathrm{~nm}$ obtido dos experimentos.

Esta relação oferece um bom ajuste com observações (linhas pontilhadas, Fig. 4.2-2). Segundo, foram modeladas as observações da Fig. 4.2-3 usando uma distribuição de Poisson. Para $Z_{n}<2$ uma distribuição de Poisson ajusta bem. Entretanto, para $Z_{n} \geq 3$ o ajuste já não é tão bom. Quando microesferas foram grudadas ao substrato (Fig. 4.2-3b) ou quando o ATP foi depletado das células, o ajuste é quase perfeito. Espacialmente, a probabilidade de um salto $Z_{n}>3$ com uma dada distância de um outro salto excede a prevista por um modelo Browniano por em torno de dez vezes (Fig. 4.2-4). As simulações de movimento Browniano foram feitas usando uma distribuição Gaussiana com média zero e desvio padrão de $6.07 \mathrm{~nm}$, obtido dos experimentos de $24^{\circ} \mathrm{C}$. Foram feiras 15000 simulações com 9000 passos. Juntamente, essas observações indicam que grandes eventos no CSK não são independentes, mas correlacionados no tempo e espaço.

O CSK de células vivas é um sistema mecanicamente ativo e gerador de stress devido a contínua injeção de energia química na forma de hidrólise de ATP e é caracterizada por flutuações fora do equilíbrio na rede [7]. Redes de proteínas reconstituídas in vitro são metabolicamente ativas e foi mostrado que captura algumas destas mesmas interessantes características [53,54], 


\section{A Dinâmica do Citoesqueleto e Abalos Sísmicos}

mas, tais sistemas não tem adesões focais, como em células vivas, e geralmente não são estudadas envolvendo suporte de estresse mecânico [50]. Desta maneira, a correspondência entre redes de CSK nativas versus reconstituídas podem diferenciar em maneiras fundamentais. Aqui foram examinadas em células vivas, mas em grandes detalhes, a natureza dessas flutuações fora do equilíbrio.

A lei de Gutenberg-Richter expressa uma relação de lei de potência entre a magnitude e o número total de eventos de abalos sísmicos numa dada região, como foi visto em células. Neste caso, deslocamentos em nano escala das microesferas vêm de flutuações térmicas pontuadas por flutuações fora do equilíbrio muito maiores, que exibem distribuições com caudas não Gaussianas aproximando-se de uma lei de potência. A lei de Omori descreve uma lei de potência dependente do número de aftershocks por unidade de tempo com expoente variando de 0.9 a 1.5, enquanto que para células foi encontrado 0.5. Tal comportamento implica que o processo de relaxação da crosta terrestre é um sistema complexo para o qual um estado típico não existe. Similar relaxação não exponencial para um estado típico tem sido observado em vários processos físicos e sistemas sociais tais como vidros de spin [26], fenômeno de microfratura [56], tráfego de internet [57], e mercado de finanças [55].

\subsection{Conclusões}

Foi reportado aqui que o CSK de células vivas exibe abruptas reconfigurações locais juntamente com transmissão de movimentos detectáveis a grandes distâncias numa maneira reminiscente a tremores na crosta terrestre. Esses eventos na célula assemelham-se quantitativamente a típicas leis empíricas de abalos sísmicos, incluindo falhas estruturais hierárquicas, distribuição de energia cumulativa que segue a lei de Gutenberg-Richter, a partir de um determinado $Z$, e a taxa de choques posteriores que decai de acordo com a lei de Omori. Essas flutuações locais 


\section{A Dinâmica do Citoesqueleto e Abalos Sísmicos}

fora do equilíbrio representa uma acomodação repentina dissipativa de uma falha estrutural e leva ao que foi chamado de cytoquake. 


\section{Capítulo 5}

\section{Análise Estatística para Counting Data}

No Capítulo 4 foram analisados os dados de deslocamentos das microesferas anexadas ao citoesqueleto (CSK), e interpretados fazendo uma correlação com as leis empíricas de abalos sísmicos na crosta da terra. O ajuste das distribuições de densidade de probabilidades, aqui renomeado $f(M)$, da magnitude $M$ de deslocamentos foram feitos usando mínimos quadrados, em que a distribuição do erro é assumida como sendo uma Gaussiana. Todavia, quando os dados em estudo tem uma distribuição de probabilidade tipo lei de potência, como no caso da lei de Gutenberg-Richter, ver Fig. 4.1-1-d, suposições de erros com distribuição Gaussiana não são ideais, uma vez que o número de eventos são discretos e com variâncias desiguais [58,59]. Em um caso como esse, deve-se tomar cuidados extra. O ideal é usar distribuições de probabilidades discretas, e com variância que variem com a média, um método conhecido como regressão linear generalizada.

Distribuições probabilísticas, ou dados frequenciais, quando não existe uma normalização, podem ser representadas dividindo a magnitude $M$ dos eventos em $p$ intervalos $\Delta M$, bins, iguais e centrados em $M_{1}, M_{2}, \ldots, M_{j}, \ldots, M_{p}$. De outra forma, os dados podem ser divididos 


\section{Análise Estatística para Counting Data}

em incrementos igualmente espaçados na escala logarítmica, $\Delta \log M$. Assim, em cada bin, $\log M_{j} \pm(\Delta \log M) / 2$, os dados de $M$ nesse intervalo são contados resultando em uma série de números inteiros e não negativos $N_{j}$, para $j=1, \ldots, p$. Esses dados, mesmo depois de normalizados por uma unidade temporal, $F_{j}=N_{j} / T$, ainda é um conjunto de dados discretos uma vez que os mesmos estão separados por um múltiplo de $T$ [58].

Tem-se agora dados frequenciais incrementais $F_{j}=F_{j}\left(M_{j}\right)=f_{j}\left(M_{j}\right) \delta M$, onde $f_{i}$ é a distribuição de densidade e $\delta M$ é o intervalo do bin [58]. O modelo a ser testado neste caso seria uma lei de potência, $F(M)=\alpha M^{-C-1} \delta M$, onde $\alpha$ é uma constante de proporcionalidade e $C$ é um expoente de escala. Uma maneira comum de se testar essa lei é usando logaritmos: $\log (F)=\log (\alpha)-(C+1) \log (M)+\log (\delta M)$ e usar regressão linear comum $y=a+\beta x$. Entretanto, regressão linear comum pressupõe que os valores $y$ encontrados na regressão, $y_{i}$, sejam distribuídos em torno de um valor médio $\lambda_{i}=\lambda\left(x_{i}\right)$ de acordo com uma distribuição Gaussiana dada por [58]:

$$
f\left(y_{i}\right)=\frac{1}{\sqrt{2 \pi \sigma^{2}}} \exp \left\{-\frac{1}{2 \sigma^{2}}\left(y_{i}-\lambda_{i}\right)^{2}\right\},
$$

onde $\sigma$ é o desvio padrão dos erros, assumido como sendo igual para diferentes $y_{i}$ s.

O uso da regressão linear comum é criticada por conta da tendência que é introduzida [58,59], uma vez que os eventos raros são de grandes magnitudes e têm efeitos desproporcionais no ajuste. Desta maneira, é proposto o uso da distribuição discreta de Poisson para os erros $[58,59]$. Assim, cada $y_{i}$ teria uma distribuição de Poisson com variância igual a média $\mu_{i}$, e função de probabilidade dada por:

$$
f\left(y_{i}\right)=\frac{\lambda_{i}^{y_{i}}}{y_{i} !} \exp \left(-\lambda_{i}\right)
$$

onde $y_{i}$ são inteiros positivos $\left(y_{i}=0,1,2, \ldots\right)$. 


\section{Análise Estatística para Counting Data}

Observando a Eq. 5.2, pode-se notar que, em termos gerais, o fatorial restringe $y_{i}$ a números inteiros e positivos. Por outro lado, a distribuição de Poisson assume que $f(0)=\exp \left(-\lambda_{i}\right)$, o que permite que se tenha frequências $F_{i}$ iguais a zero, em contraste a equação de $\log (F)$ escrita anteriormente, onde os bins vazios são ignorados, uma vez que $\log (0)=-\infty$ [58].

No Cap. 4 foi mostrado o comportamento não Gaussiano dos dados experimentais, especificamente os deslocamentos. Esses dados poderiam ser contestados pelo fato do uso de mínimos quadrados, ou seja, a cauda longa observada estaria dentro do erro de um ajuste com a regressão generalizada. Assim, o uso desse tipo de regressão é útil para checar os dados em relação ao fato de ser ou não ser Gaussiano, sendo então mais uma maneira de atestar a confiabilidade dos eventos raros observados.

Outra maneira de se analisar os dados é com o uso de Stable Distributions [60]. Distribuições cuja soma de $n$ variáveis aleatórias distribuídas idêntica e independentemente não muda sua forma funcional, independentemente do valor de $n$ [60]. Dentre essas distribuições, pode-se citar: Gaussiana, Lorentziana e Lévy. Essas distribuições são usualmente encontradas em estudos envolvendo distribuições heavy-tailed, com aplicações em diversos ramos, como economia, estudos de abalos sísmicos, mercado de ações, processos de busca por alimentos (foraging), etc $[58-62]$.

A forma geral para a função característica (transformada de Fourier inversa da densidade de probabilidade) de um processo estável é dada por [60]:

$$
\ln \phi(q)= \begin{cases}i \mu q-\gamma|q|^{\alpha}\left[1-i \beta \frac{q}{|q|} \tan \left(\frac{\pi}{2} \alpha\right)\right], & \alpha \neq 1 \\ i \mu q-\gamma|q|\left[1+i \beta \frac{q}{|q|} \frac{2}{\pi} \ln |q|\right], & \alpha=1\end{cases}
$$

onde $0<\alpha \leq 2$, $\gamma$ é um fator de escala positivo, $\mu$ é um número real e $\beta$ é um parâmetro de assimetria que varia de -1 a 1 . Assim, dependendo dos parâmetros, tem-se um tipo de 
distribuição:

- $\alpha=1 / 2$ e $\beta=1 \rightarrow$ Lévy;

- $\alpha=1$ e $\beta=0 \rightarrow$ Lorentziana;

- $\alpha=2 \rightarrow$ Gaussiana.

Usando então regressão linear generalizada e stable distributions pode-se melhor analisar os dados e entender o tipo de distribuição que os melhor descrevem.

\subsection{Métodos}

Usando os mesmos dados experimentais para a magnitude dos deslocamentos do Cap. 4, estes dados são ajustados usando regressão linear generalizada. Os ajustes serão feitos com dois tipos de distribuição de erros: Poisson e Gaussiana. Para isso será utilizado o toolbox de estatística do software Matlab [63]. Com isso pretende-se analisar se os dados são Gaussianos ou não.

Após essa etapa, os dados serão ajustados com stable distributions. Para isso será utilizado o pacote STBL: Alpha stable distributions for MATLAB [64]. Com isso pretende-se definir que tipo de distribuição melhor caracteriza os dados experimentais.

\subsection{Resultados e Discussão}

Os ajustes dos dados experimentais para a magnitude dos deslocamentos do Cap. 4, ver Fig. 4.11-d, estão mostrados na Fig. 5.2-1. A Fig. 5.2-1a foi feita usando distribuição de Poisson para os erros, e a Fig. 5.2-1b foi feira usando distribuição Gaussiana para os erros. Pode-se notar que 


\section{Análise Estatística para Counting Data}

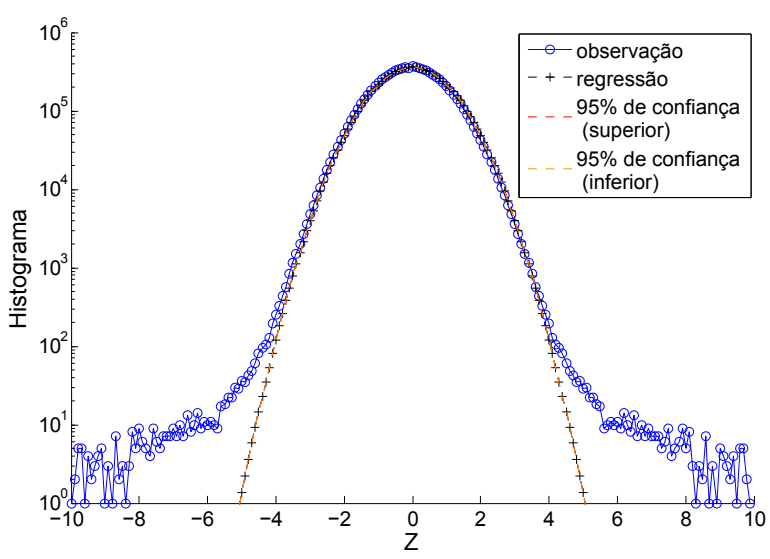

(a) Erro de Poisson.

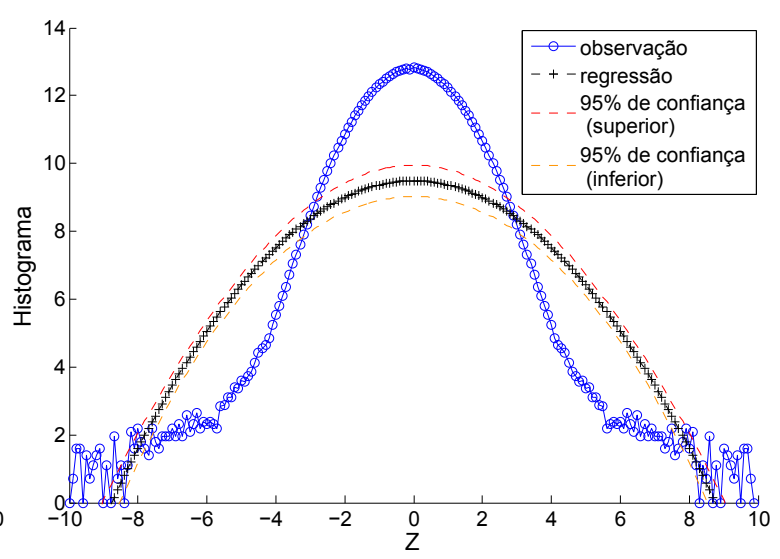

(b) Erro Gaussiano.

Figura 5.2-1. Dados experimentais para a magnitude dos deslocamentos do Cap. 4 ajustados com regressão linear generalizada com erros dados por duas distribuições: Poisson e Gaussiana.

para a distribuição de erros Gaussiana o ajuste fica muito fora do observado, visto que tem uma distribuição de erros com variância constante. Já com distribuição de erros de Poisson, a variância aumenta com a média, fazendo com que o ajuste fique ótimo na região central, mas fique fora nas regiões laterias. Essas figuras mostram que mesmo usando regressão generalizada, não se consegue afirmar que esses dados tenham comportamento Gaussiano, mostrando que esses eventos são reais.

A Fig. 5.2-2 mostra o ajuste para as stable distributions. Os parâmetros encontrados são: $\alpha=1.99, \beta=0.00, \gamma=0.70$ e $\mu=0.00$. Assim, os dados observados caem dentro da distribuição de Lévy se aproximando de uma distribuição Gaussiana.

\subsection{Conclusões}

Mesmo analisando os dados sob o ponto de vista da regressão generalizada, assumindo os erros do ajuste sendo dados por uma distribuição de Poisson, pode-se concluir que os dados não são Gaussianos. Embora a cauda apresentada na Fig.4.1-1 (d) não seja longa, nesse estudo ela é relevante e é consequência de eventos raros observados. Eventos cujas características são 


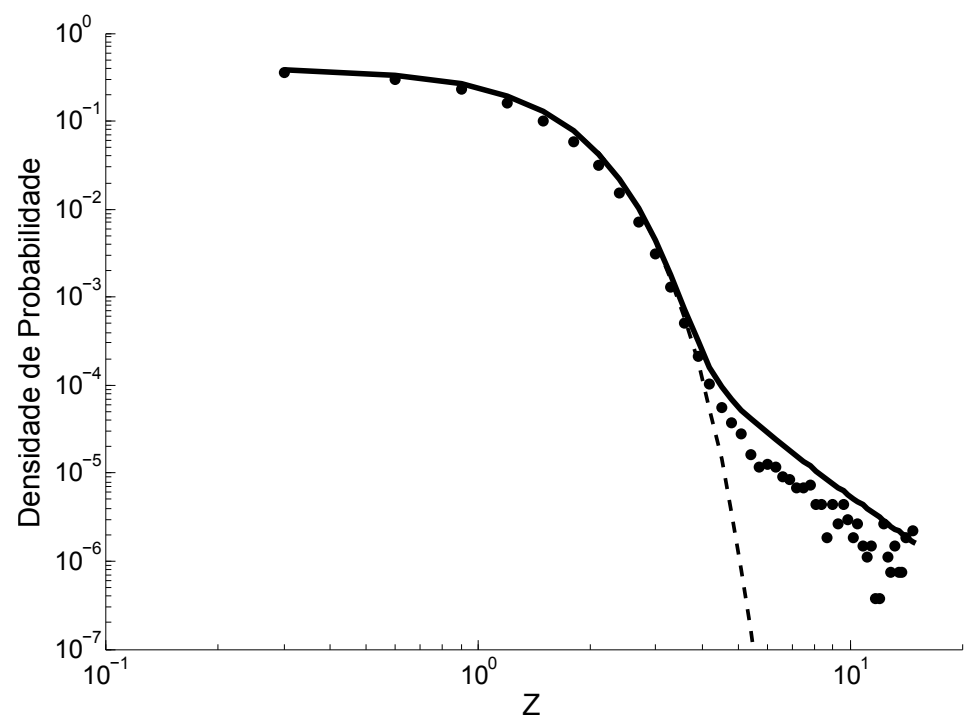

Figura 5.2-2. Densidade de Probabilidade dos dados mostrados na Fig. 5.2-1, pontos, ajustados com stable distribution, linha contínua. A linha tracejada mostra um ajuste Gaussiano. Os parâmetros encontrados são: $\alpha=1.99, \beta=0.00, \gamma=0.70$ e $\mu=0.00$.

melhor ajustadas por Lévy, embora o parâmetro $\alpha$ seja próximo a 2 .

No próximo capítulo serão exploradas maneiras de se evidenciar a cauda observada por meio de experimentos com alta frequência de aquisição de dados. 


\section{Capítulo 6}

\section{Difusão Anômala Evidenciada a Altas}

\section{Frequências}

Usualmente, o rastreamento de microesferas ligadas ao citoesqueleto (CSK) é feito usando 12 a 16 frames por segundo (fps) por alguns minutos [7]. A quantidade gerada de dados para um experimento de alguns minutos é grande, da ordem de giga bytes, sendo inviável o armazenamento de toda a série de imagens obtidas durante os experimentos. Esse é um fator importante e limitante a se levar em consideração. Outros fatores importantes estão relacionados a limitação em aumentar o fps, como por exemplo: comunicação da câmara com o computador, tempo de exposição da câmera, velocidade computacional para análises online, dentre outros.

A trajetória observada das microesferas é governada por vários fatores, como flutuação térmica, gradientes de pressão e motores celulares. Nesse contexto, nossa hipótese é que os eventos devido a flutuação térmica não devem causar os eventos anômalos, apenas os eventos devido a fatores ativos. Essa hipótese é reforçada pelo fato dos eventos anômalos desaparecerem quando a energia dos motores celulares, ATP, é retirada da célula. Caso se suponha que os eventos 
Difusão Anômala Evidenciada a Altas Frequências

anômalos sejam rápidos, em relação a taxa de amostragem, fps, e tenham a mesma ordem de magnitude temporal. Medidas com baixos valores de fps, a flutuação térmica estaria prevalecendo nas medições, mascarando os eventos anômalos. Desta maneira, aumentar o fps deveria aumentar o número de eventos raros detectados. Assim, a cauda vista nos histogramas de $Z$ ficaria evidenciada, como comentado no Capítulo 3, abrindo novas opções de análises para a dinâmica do CSK.

\subsection{Métodos}

Para esse estudo serão utilizados dois tipos de células: a primeira é uma célula do tipo epitelial que é estável e com pouca atividade mecânica, já o segundo tipo de célula é a de músculo liso, que é mais ativa, cuja função é manter o tônus de órgãos ocos, que é uma atividade bastante dinâmica.

Para os experimentos de difusão foram utilizados um microscópio invertido (Leica DMI 4000B) anexado a uma câmera (Andor Neo sCMOS). Esta câmera é de alta velocidade podendo chegar a $1000 \mathrm{fps}^{1}$. O microscópio possui um invólucro de acrílico onde é possível recriar as condições de uma incubadora, temperatura de $37^{\circ} \mathrm{C}$ e $5 \%$ de $\mathrm{CO}_{2}$. Este aparato possui dois sistemas de aquecimento: para amostra pequenas (Warner Instrument Corporation, TC-324B), e outro para o ambiente definido pelo invólucro (desenvolvido no $\mathrm{LabM}^{2}$ ). O controle de gás é feito utilizando um misturador de gás (Okolab, 2GF Mixer), que é responsável por gerar a proporção de $5 \%$ de $\mathrm{CO}_{2}$ e $95 \%$ de ar, onde o ar é adquirido por um compressor de ar (Cristófoli 9001), e o $\mathrm{CO}_{2}$ vem de um cilindro. Após feita a mistura, o gás é umidificado e levado até a amostra. Desta maneira, as amostras podem ficar no microscópio como se estivessem na incubadora, permitindo experimentos com longos períodos e a utilização da mesma amostra

\footnotetext{
${ }^{1}$ Valor teórico máximo, com imagens guardadas no buffer, sem acesso em tempo real.
} 


\section{Difusão Anômala Evidenciada a Altas Frequências}

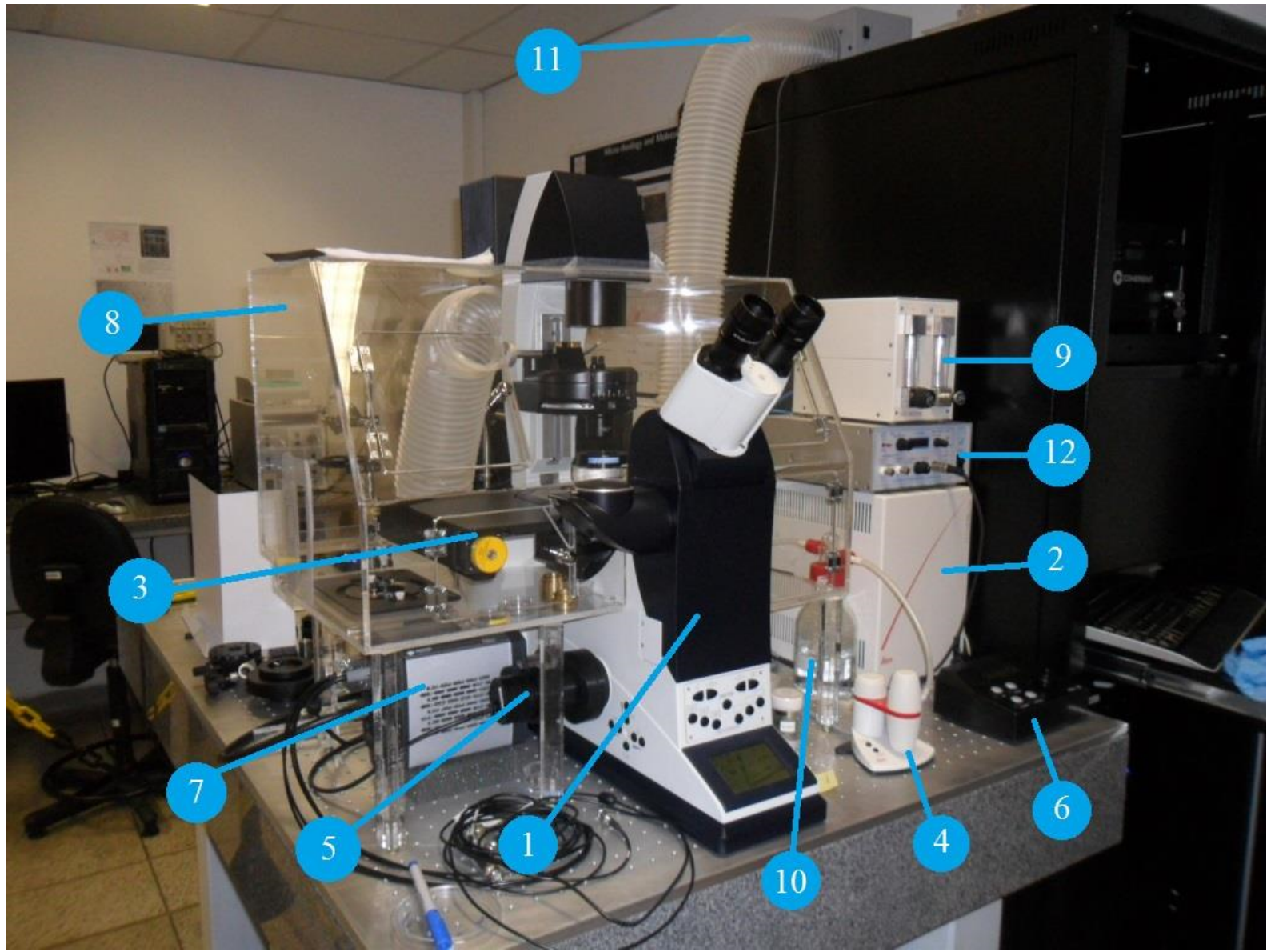

Figura 6.1-1. Montagem experimental para aquisição em altas frequências no $\mathrm{LabM}^{2}$ : 1) microscópio (Leica DMI 4000B), 2) fonte do microscópio, 3) estágio motorizado para controle do eixo x e y, 4) controlador do eixo x e y, 5)eixo z, 6) controlador do eixo z, 7) câmera (Andor Neo sCMOS), 8) incubador de acrílico, 9) misturador de gás (Okolab, 2GF Mixer), 10) humidificador, 11) aquecedor, 12) controle do aquecimento da microincubadora (Warner Instrument Corporation, TC-324B).

para diversas aquisições. A Fig. 6.1-1 mostra a montagem experimental descrita acima.

As células foram cultivadas em poços de 96 ou placas de Petri de $35 \mathrm{~mm}$ como descrito no Capítulo 3. Foram usadas esferas ferrimagnéticas de $4.5 \mu \mathrm{m}$ de diâmetro. A temperatura foi mantida usando o microincubador.

O microscópio e a câmara são acessados por um software livre chamado MicroManager [65], que foi desenvolvido a partir do ImageJ [66]. As imagens obtidas são analisadas pelo mesmo software já comentado anteriormente, Capítulo 3 e Apêndice E. 


\section{Difusão Anômala Evidenciada a Altas Frequências}

Os experimentos para altas frequências foram realizados em duas etapas, descritas a seguir.

\section{Primeira etapa:}

As células utilizadas foram BEAS-2B (célula epitelial aderente brônquica humana normal). As células foram cultivas em poços como descrito no Apêndice D.

As medidas foram conduzidas com amostras com magnificação de $10 \times$ e $20 \times$, todas com 2 ms de exposição. A montagem experimental já foi descrita acima, com controle de temperatura, que foi mantida a $37^{\circ} \mathrm{C}$.

Foram realizados 4 amostras para cada frequência de 10, 20, 40, 77 e $200 \mathrm{fps}$ e para cada magnificação, com cerca de 20 segundos cada. Esses valores foram escolhidos por limitações no software e memória RAM do computador.

\section{Segunda etapa:}

Na segunda etapa foi usada a mesma montagem experimental, mas com diferente tipo de célula. Foram usadas células RASM (rabbit aortic smooth muscle), e magnificação de $20 \times$.

Para vencer as limitações do software e memória, bem como a precisão do instante em que a foto foi tirada, foi desenvolvido um controle externo para o trigger da câmera de maneira independente utilizando um microcontrolador ATmega328 com circuitos específicos para esse fim, ver Fig. 6.1-2. Assim, pode-se fazer altas frequências e também aumentar o número de imagens obtidas. Foram feitas então 8000 imagens para as frequências de: 120, 100, 80, 60, 40 e 20 fps. Foram realizadas 6 medidas para cada frequência, em amostras preparadas em placa de Petri de $35 \mathrm{~mm}$. 


\section{Difusão Anômala Evidenciada a Altas Frequências}

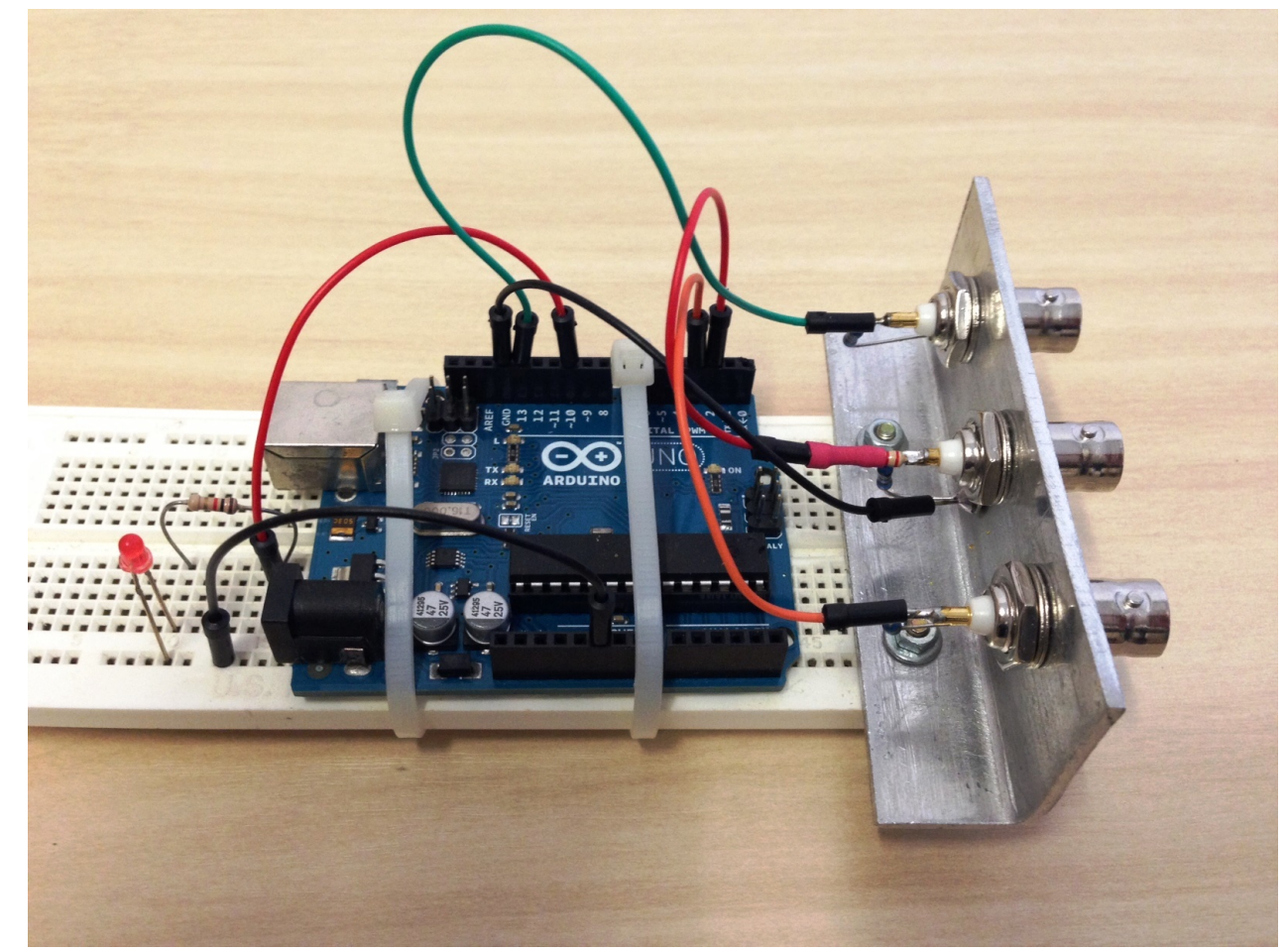

Figura 6.1-2. Microcontrolador ATmega328 feito para controle externo do trigger da câmera.

\subsection{Resultados e Discussão}

Abaixo os resultados e discussões comentados em etapas, como definidas anteriormente.

\section{Primeira etapa}

Realizados os experimentos, os MSDs foram calculados e reunidos em um mesmo gráfico por magnificação. A Fig. 6.2-3 mostra os MSDs e suas inclinações para frequências de 10, 20, 40, 77 e $200 \mathrm{fps}$ usando magnificação de $10 \times$. Enquanto que a Fig. 6.2-4 mostra a mesma situação para magnificação de $20 \times$.

Para ambas magnificações, o MSD mostra um platô para a frequência de 200 fps. Isso pode ter ocorrido por ser utilizado uma frequência muito alta. Nesse caso percebemos que existiu uma flutuação no intervalo temporal entre um frame e outro, gerando um erro temporal que 


\section{Difusão Anômala Evidenciada a Altas Frequências}

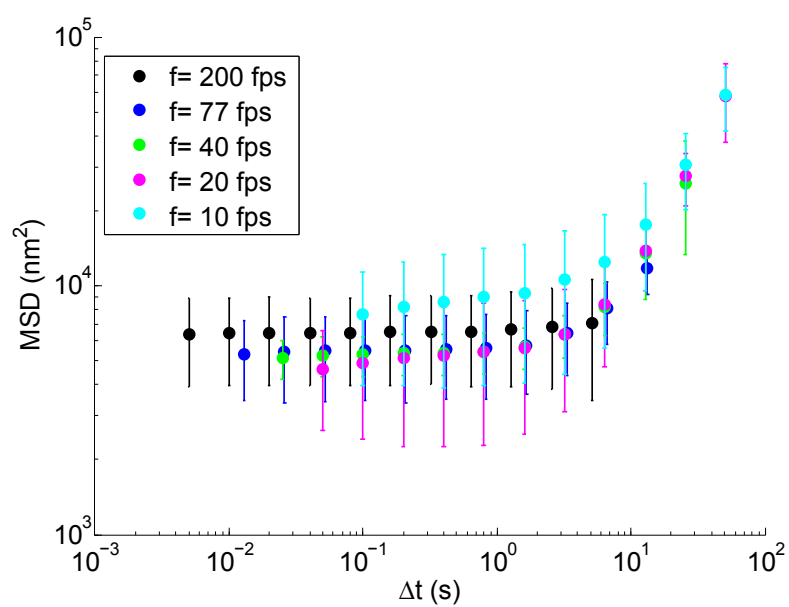

(a)

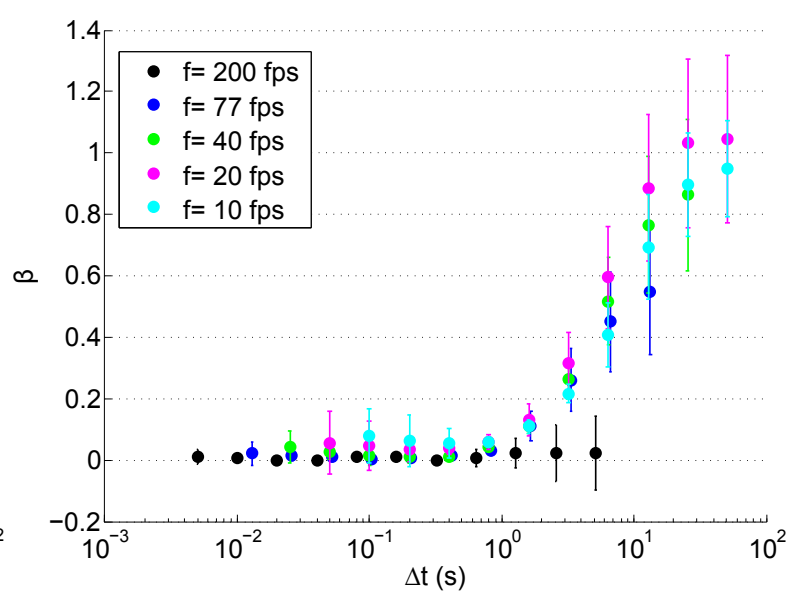

(b)

Figura 6.2-3. MSD médio (a) e inclinação (b) para experimentos com magnificação de $10 \times$.

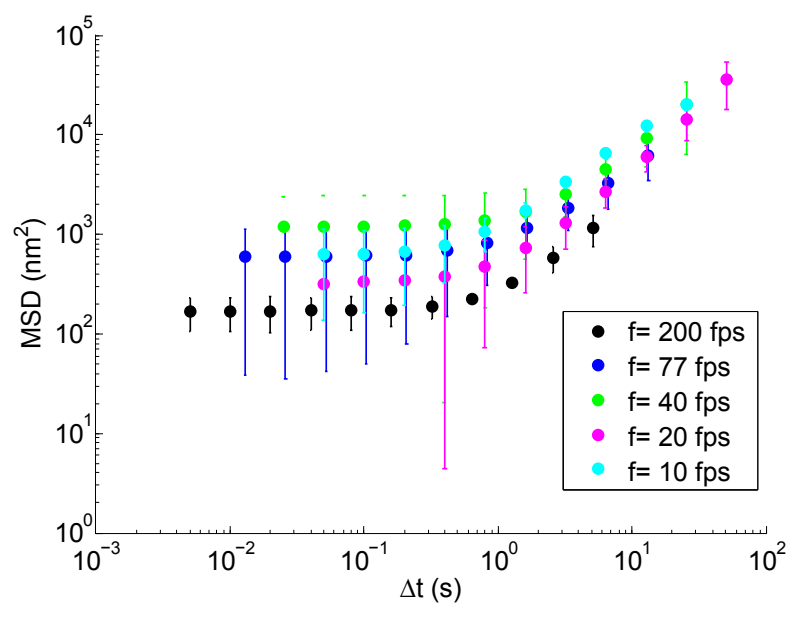

(a)

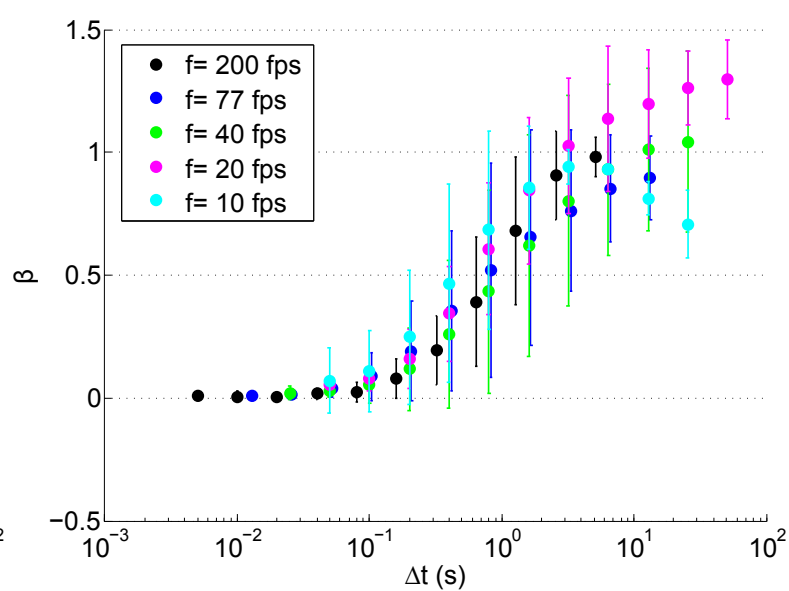

(b)

Figura 6.2-4. MSD médio (a) e inclinação (b) para experimentos com magnificação de $20 \times$.

transformou parte do dado em ruído. Para as outras frequências não é possível observar diferença clara entre um período de subdifusão e o período de superdifusão [7]. Olhando os gráficos da inclinação, também pode-se ver que esta praticamente não alcança valores superdifusivos, acima de 1 .

Os histogramas dos $Z$ s estão mostrados na Fig. 6.2-5 para frequências de 10, 20, 40, 77 e $200 \mathrm{fps}$. As coordenadas $x$ e $y$ foram colocadas juntas. Nenhum deles apresentam cauda evidenciada. 


\section{Difusão Anômala Evidenciada a Altas Frequências}

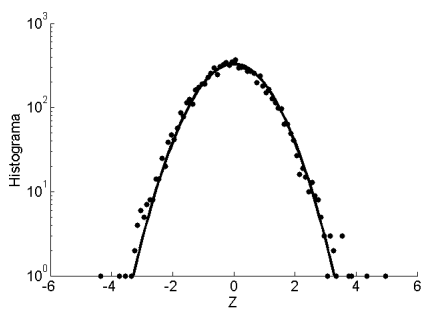

(a) $10 \mathrm{fps}$

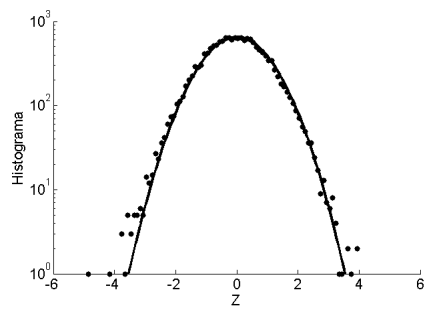

(b) $20 \mathrm{fps}$

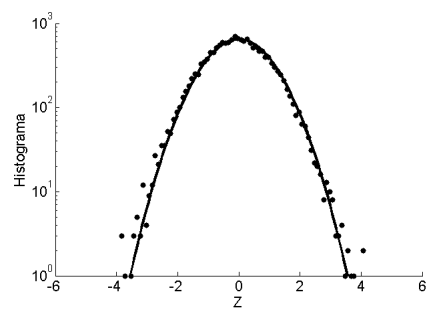

(c) $40 \mathrm{fps}$

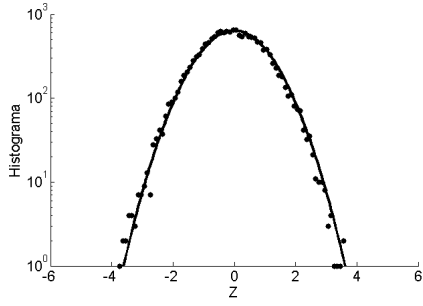

(d) $77 \mathrm{fps}$

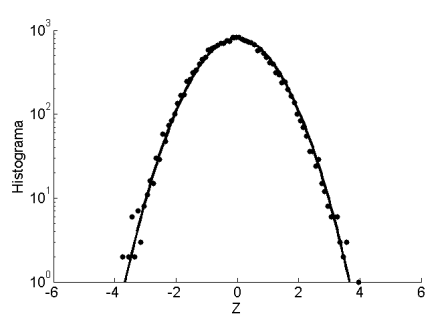

(e) $200 \mathrm{fps}$

Figura 6.2-5. Histogramas dos $Z$ 's. As linhas contínuas são os ajustes Gaussianos dados por $a e^{-x^{2} / 2 \sigma^{2}}$. (a) $10 \mathrm{fps}$ com parâmetros $a=328.00 \mathrm{e} \sigma=0.96$. (b) $20 \mathrm{fps}$ com parâmetros $a=646.00 \mathrm{e} \sigma=0.98$. (c) 40 fps com parâmetros $a=643.00$ e $\sigma=0.99$. (d) 77 fps com parâmetros $a=635.00$ e $\sigma=1.00$. (e) 200 fps com parâmetros $a=796.00$ e $\sigma=1.00$.

Note que esse resultado foi obtido para células epiteliais, cuja a atividade mecânica é baixa quando comparada com músculo liso. Assim a nova sequência de experimentos utilizou-se células de músculo liso. As células de músculo liso são mais ativas e mostram maior tendência ao remodelamento. Os resultados são mostrados a seguir.

\section{$\underline{\text { Segunda etapa }}$}

Realizados os mesmos experimentos para células de músculo liso, os histogramas encontrados estão mostrados na Fig. 6.2-6. Aqui só será mostrado os histogramas pois o interesse é em quantificar os eventos anômalos em diferentes frequências para encontrar uma situação ideal para os experimentos. Observando os histogramas, pode-se dizer que a frequência que evidencia a cauda está em torno de 20 fps.

Visualmente é possível observar a mudança na cauda nos histogramas variando a frequência. Para quantificar os eventos anômalos foi feito o seguinte: primeiramente identifica-se os pontos 


\section{Difusão Anômala Evidenciada a Altas Frequências}

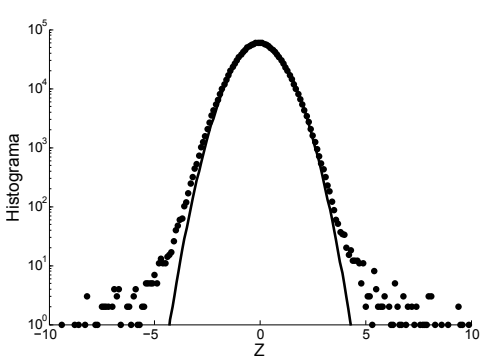

(a) $20 \mathrm{fps}$

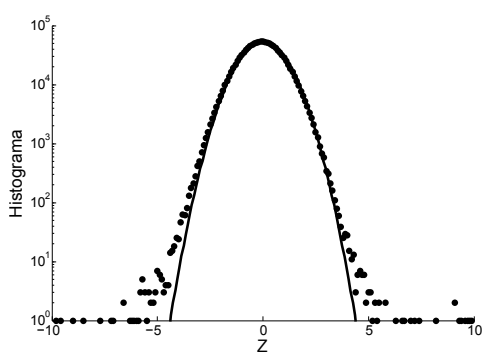

(b) $40 \mathrm{fps}$

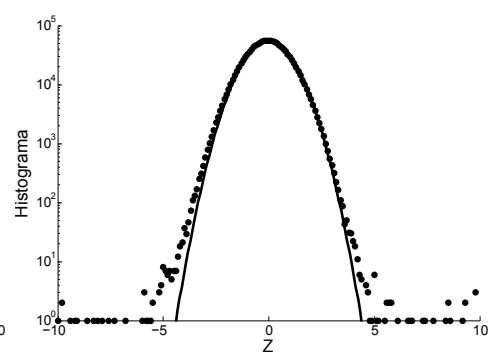

(c) $60 \mathrm{fps}$

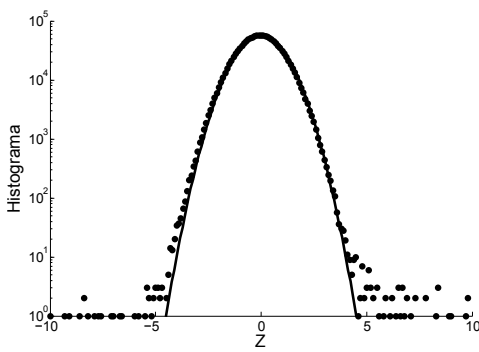

(d) $80 \mathrm{fps}$

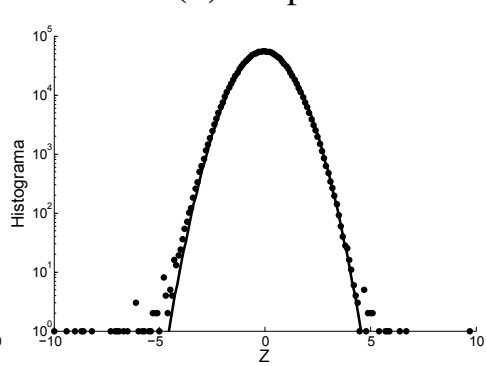

(e) $100 \mathrm{fps}$

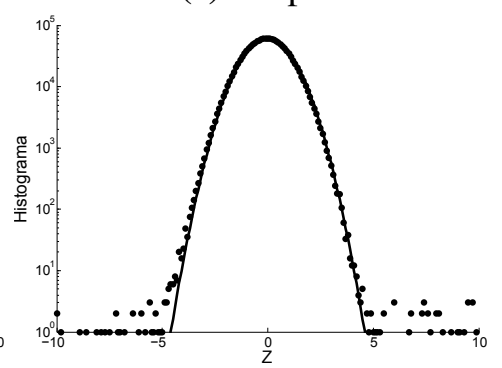

(f) $120 \mathrm{fps}$

Figura 6.2-6. Histogramas dos $Z$ 's. As linhas contínuas são os ajustes Gaussianos dados por $a e^{-x^{2} / 2 \sigma^{2}}$. (a) 20 fps com parâmetros: $a=58800$ e $\sigma=0.92$, (b) $40 \mathrm{fps}$ com parâmetros: $a=53000$ e $\sigma=0.94$, (c) 60 fps com parâmetros: $a=55200$ e $\sigma=0.94$, (d) 80 fps com parâmetros: $a=56700$ e $\sigma=0.96$, (e) 100 fps com parâmetros: $a=55100$ e $\sigma=0.98$, e (f) 120 fps com parâmetros: $a=60900$ e $\sigma=0.98$.

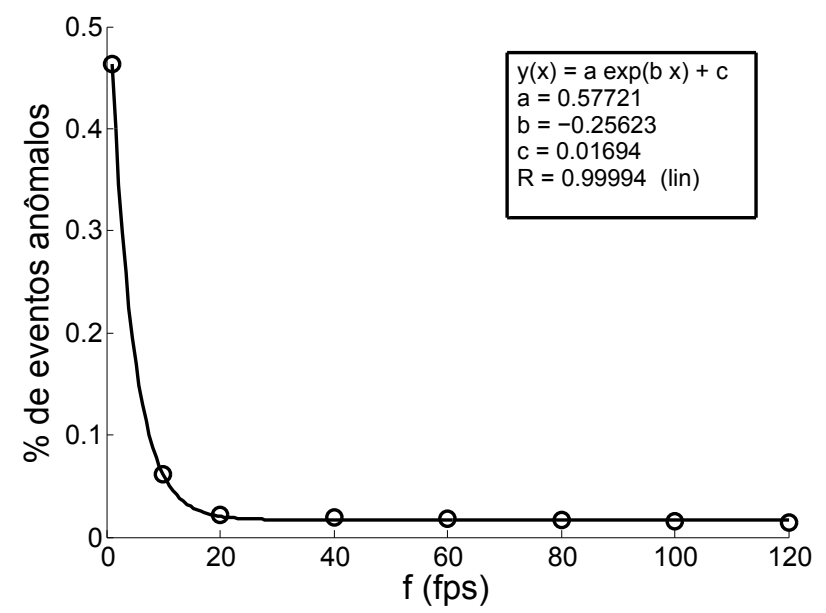

Figura 6.2-7. Porcentagem de eventos anômalos referentes aos histogramas mostrados na Fig. 6.2-6, círculos abertos. Os eventos para as frequências de 10 e $1 \mathrm{fps}$ foram obtidos a partir da frequência de $20 \mathrm{fps}$. A linha contínua representa o ajuste exponencial.

no eixo x dos histogramas onde estes se encontram com a curva do ajuste, $\pm p$; posteriormente, contabiliza-se a quantidade de eventos onde $|Z| \geq p$. Os valores encontrados estão mostrados na Fig. 6.2-7, onde os mesmos foram normalizados pelo total de pontos. 


\section{Difusão Anômala Evidenciada a Altas Frequências}

A Fig. 6.2-7 mostra que a medida que a frequência diminui, a porcentagem de eventos anômalos aumentam, deixando a cauda mais evidenciada. Esse comportamento é diferente do esperado inicialmente, e indicativo de que os eventos anômalos ocorrem em todas as escalas, persistindo para escalas temporais da ordem de segundo.

\subsection{Conclusões}

O fenômeno da difusão anômala não é relevante em células epiteliais, mas sim em músculo liso. O músculo liso é mais ativo estando em constante remodelamento para o exercício de suas funções, como manter o formato, tônus e contração celular, gerando uma cauda mais evidente nos histogramas.

Com o aumento da frequência de aquisição, não houve um evidenciamento da cauda como o esperado. A quantidade de eventos anômalos vai diminuindo exponencialmente com o aumento da frequência, o que é um indicativo de que esse comportamento esta na ordem de escala de segundo, esse resultado corrobora com o que já foi discutido no Cap. 3. 


\section{Capítulo 7}

\section{Movimento Browniano e Modelagem da}

\section{Dinâmica do Citoesqueleto}

O movimento Browniano (MB) pode ser utilizado para o estudo de sistemas complexos e na caracterização de microambientes $[67,68]$. Essas aplicações podem ser estendidas para o estudo da dinâmica do citoesqueleto (CSK).

\subsection{Movimento Browniano}

Características do comportamento do CSK podem ser entendidas através de simulações de MBs. A Fig. 7.1-1 mostra três exemplos de movimento: a) movimento puramente difusivo; b) movimento com uma tendência, ou drift, (superdifusivo) e c) movimento confinado (subdifusivo).

Nesses exemplos as coordenadas $x$ e $y$ foram geradas por números aleatórios dados por uma distribuição Gaussiana. No caso das Figs. 7.1-1 a e c , foi usada uma distribuição Gaussiana com média zero e desvio um, e já para o caso $\mathbf{b}$ foi usada uma distribuição Gaussiana com média 0.9 


\section{Movimento Browniano e Modelagem da Dinâmica do Citoesqueleto}
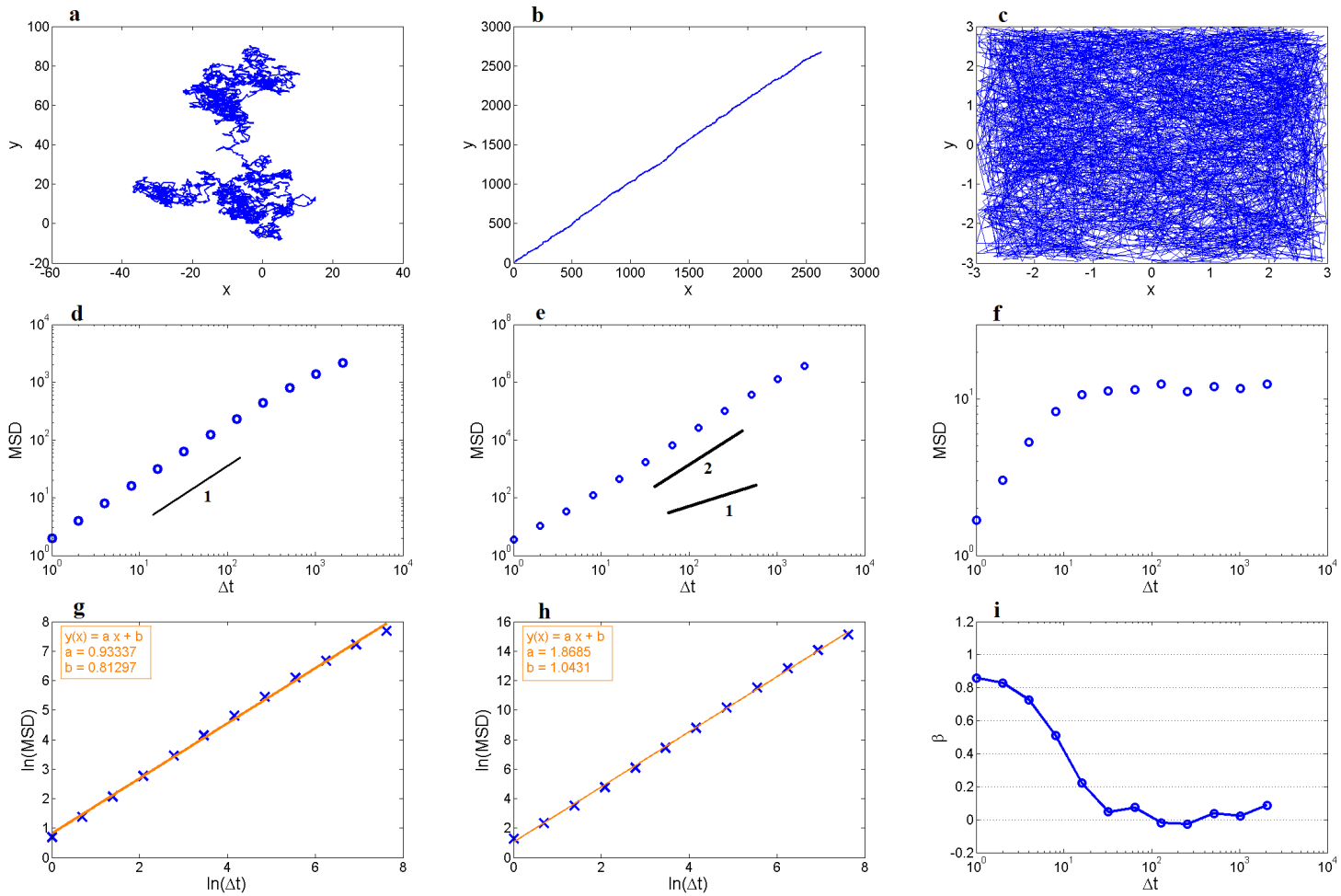

Figura 7.1-1. Tipos de MB simulados para uma partícula: a: movimento puramente difusivo; b: movimento com uma tedência; c: movimento confinado. Deslocamento quadrático médio (MSD) dos tipos de MB, as retas sólidas indicam inclinação de 1 e 2: d: MSD médio do caso a para 20 trajetórias; e: MSD médio do caso b para 20 trajetórias; f: MSD do caso c para uma trajetória. g: ajuste linear do $\ln (\mathrm{MSD})$ por $\ln (\Delta t)$ para o caso a; h: ajuste linear do $\ln (\mathrm{MSD})$ por $\ln (\Delta t)$ para o caso b; i: inclinação do MSD definida pela Eq. 7 do texto principal para o caso c.

e desvio 1. A cada passo, que representa uma variável temporal, é gerado um número aleatório para cada coordenada:

$$
\begin{aligned}
& x_{i}=x_{i-1}+\xi_{i}^{x} \\
& y_{i}=y_{i-1}+\xi_{i}^{y},
\end{aligned}
$$

onde $\xi_{i}^{x, y}$ são números independentes Gaussianos com média zero e variância igual a 1. As coordenadas são adimensionais, usadas apenas para a representação da trajetória. A simulação foi iniciada em $(0,0)$, e foram simulados um total de 3000 passos.

A partir das trajetórias, pode-se calcular o MSD. No cálculo do MSD médio sobre várias 


\section{Movimento Browniano e Modelagem da Dinâmica do Citoesqueleto}

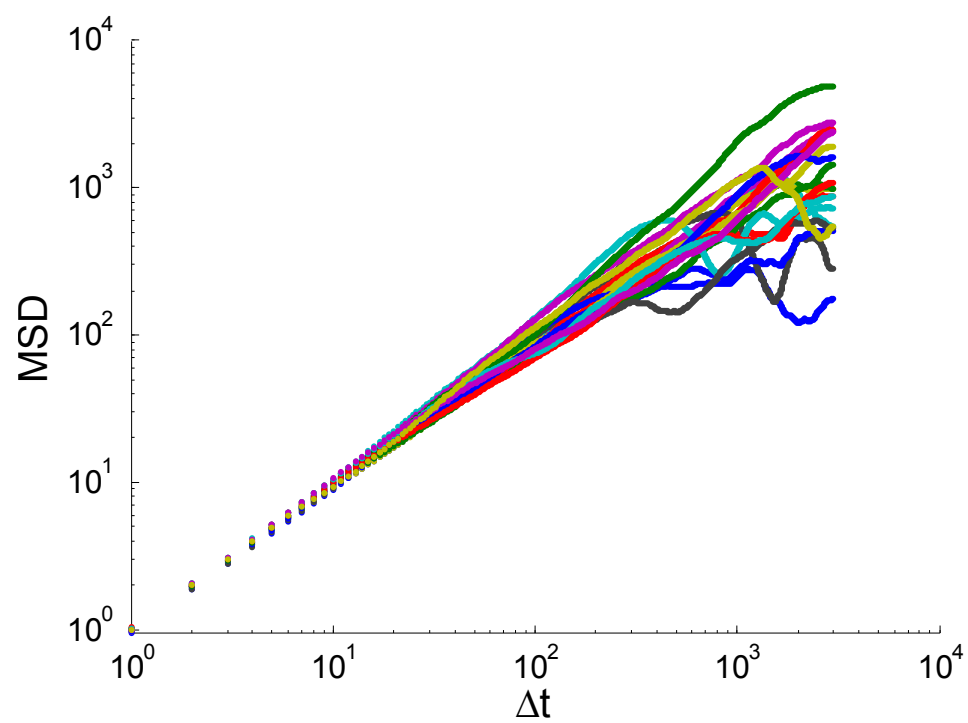

Figura 7.1-2. Deslocamentos quadráticos (MSD) de 20 trajetórias de MBs difusivos. Pode-se notar que para a última década a variação é grande, gerando um erro estatístico muito maior para os dados finais que para os dados iniciais na hora de se calcular o MSD médio. Desta maneira pode-se descartar os dados finais e utilizar os dados das duas décadas iniciais para se ter mais precisão, se necessário.

trajetórias, o erro estatístico é maior nos dados finais do que nos dados iniciais. Isso pode ser observado na Fig. 7.1-2. Nesta figura são mostrados os MSDs de 20 trajetórias de MB difusivo, onde pode-se notar que para a última década a variação é grande. Desta maneira pode-se descartar os dados finais e utilizar os dados das duas décadas iniciais para se ter mais precisão, se necessário.

Para obter-se MSDs dos três tipos de MB mostrados, foram geradas 20 trajetórias para o caso a e b, e calculado a média para cada caso. Para o caso c foi usada apenas uma trajetória. Os MSDs obtidos então estão mostrados nas Figs. 7.1-1 d, e e f.

No caso do MB difusivo, o MSD é dado por: $\left\langle\Delta r(\Delta t)^{2}\right\rangle=4 D \Delta t$, para duas dimensões, onde $D$ é o coeficiente de difusão. Assim, calculando o ln do MSD e do $\Delta t$ e fazendo um ajuste linear, pode-se encontrar $D$ e verificar a dependência linear com o tempo. Este ajuste está mostrado na Fig. 7.1-1 g, de onde encontra-se: $\ln (\mathrm{MSD})=a \ln (\Delta t)+b$, ou seja, $\mathrm{MSD}=e^{b} \Delta t^{a}$. Assim, tem-se $D=e^{b}$ e $a \approx 1$, como esperado. 


\section{Movimento Browniano e Modelagem da Dinâmica do Citoesqueleto}

Quando o movimento apresenta um MSD com comportamento não linear com o tempo, tem-se o que se chama de difusão anômala. Assim, faz-se importante o conhecimento da dependência com o tempo, ou seja, o coeficiente $\beta$, como definido na Eq. 3.2. Desta maneira, como no caso difusivo, foi ajustado o ln do MSD pelo ln do $\Delta t$, e o resultado está mostrado na

Fig. 7.1-1 h para o caso b. A partir do ajuste pode-se ver que o MSD tem um comportamento superdifusivo, com inclinação de 1.9, chegando quase um movimento balístico.

No caso confinado, também foi calculada a inclinação $\beta$, ver Eq. 3.2. Esta inclinação está mostrada na Fig. 7.1-1 i. Pode-se ver que o MSD tem um comportamento subdifusivo até chegar a inclinação zero, indicando o confinamento.

Em um sistema biológico, como as células, o movimento de uma partícula em seu interior pode ser afetado por diversos fatores: efeito térmico (caso a), por gradientes de pressão, ou motores celulares (caso b) e também permanecer confinada por algum componente celular (caso c). Esses tipos de trajetórias mostradas anteriormente também podem ser úteis para o estudo do comportamento do CSK. Este exibe uma dinâmica que contém saltos e confinamentos, oque nos leva a crer que seu movimento é uma mistura dos três tipos, Fig. 7.1-3. Assim, o caso a representaria o movimento térmico dos componentes dos filamento de actina, o caso b seria o movimento ativo, gerado por ATP, e o caso c ocorreria quando os elementos do CSK estão presos em armadilhas geradas pela interação entre vizinhos dos seus componentes.

Dessa maneira, pode-se recriar o movimento do CSK, simulando o comportamento das microesferas usando um conjunto dos três tipos de MB. Este comportamento pode ser observado experimentalmente, como mostrado na Fig. 3.2-5. O uso do rastreamento de partículas tem sido amplamente utilizado e tem um papel importante na caracterização de microambientes heterogêneos $[67,68]$. Como por exemplo, o tamanho das armadilhas observadas são úteis para mostrar o tipo de ambiente onde a partícula observada está se difundindo, e também, no uso de partículas de prova, ou seja, qual o tamanho ideal a ser usado. 


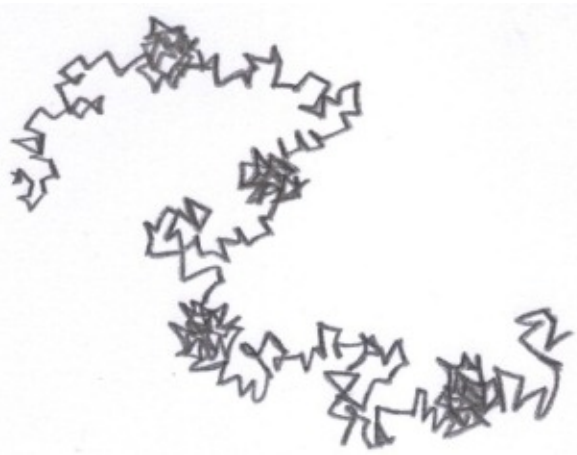

Figura 7.1-3. Movimento criado a partir dos três tipos apresentado na Fig.7.1-1 a, b e c que simularia o movimento do CSK. O caso a representaria o movimento térmico dos componentes dos filamento de actina, o caso b seria o movimento ativo, gerado por ATP, e o caso c ocorreria quando os elementos do CSK estão presos em armadilhas geradas pela interação entre vizinhos dos seus componentes.

Outro fator importante a se citar é a frequência a ser usada, seja para uma simulação, ou seja a frequência de captura de imagens necessária para um experimento. Para isso pode-se analisar a distância total, $d$, percorrida por uma partícula Browniana num dado tempo, $t_{p}$. A distância média por passo de uma partícula é dada por $\sqrt{\left\langle\Delta r^{2}\left(t_{\text {passo }}\right)\right\rangle}=\sqrt{\frac{2 k_{B} T}{3 \pi a \eta} t_{\text {passo }}}$. Desta maneira, a distância $d$ seria dada pela multiplicação da raiz do número de passos em $t_{p}$ multiplicado pela distância em cada passo [67]. Assim:

$$
t_{p}=\frac{d^{2}}{\left\langle\Delta r^{2}\left(t_{\text {passo }}\right)\right\rangle} t_{\text {passo }}=\frac{3 \pi \eta a d^{2}}{2 k_{B} T}
$$

A partir da Eq. 7.3, tem-se uma idéia da taxa de passos a ser utilizada, por exemplo, a taxa de passos deve ser menor que $t_{p}$ para evitar movimentos da partícula que sejam maiores que $d$ [67]. A distância $d$ também pode dar informações acerca do tamanho da partícula a ser usada [67]. Uma partícula maior que $d$ dará uma estimativa da reologia local (bulk), enquanto que uma menor, poderá ficar presa e dar características estruturais do meio.

Seguindo esta linha de raciocínio, a Fig. 7.1-4 mostra um MB gerado alternando-se entre períodos difusivos, e períodos de confinamento. Essa é uma maneira simples de se simular situações onde temos aprisionamento e desprendimento como no CSK. 


\section{Movimento Browniano e Modelagem da Dinâmica do Citoesqueleto}

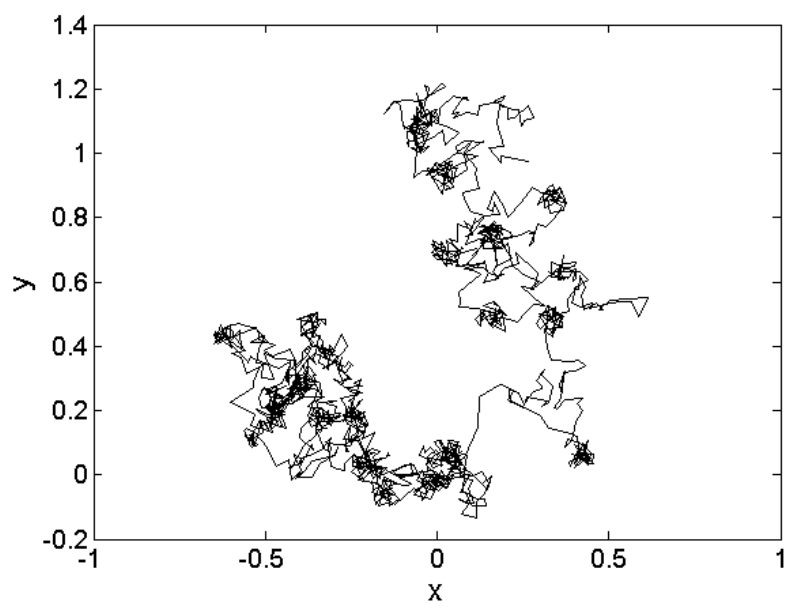

Figura 7.1-4. MB criado alternando-se entre períodos de confinamento e difusivo.

Uma maneira alternativa para a simulação do que é observado no CSK é fazer analogias entre sistemas massa-mola. Sabe-se que a microesfera recoberta de RGD se adere fortemente aos receptores de integrina que estão conectados aos filamentos de actina. Esses filamentos formam as fibras de estresse nas células, e também são responsáveis pelas adesões focais. Na Fig. 7.1-5 pode-se ver a adesão focal em torno da microesfera. As fibras de estresse nas células são elásticas, apresentando um módulo elástico [69], desta maneira o sistema microesfera ligada à actina pode ser associado a um potencial tipo mola. Assim, essas fibras podem ser representadas por molas, e um sistema massa-mola ilustraria de maneira satisfatória o sistema de interesse, ver Fig. 7.1-6. Adicionando então movimento Browniano a esse sistema massa-mola será possível obter resultados similares aos observados experimentalmente.

As próximas seções deste capítulo tratam do MB de uma maneira mais formal e também do mesmo em um potencial tipo mola. A partir daí, um acoplamento entre MB e sistema massa-mola é feito para as simulações do sistema experimental. Essa modelagem ainda é complementada com o modelo de blocos deslizantes de Turcotte [70], que é um modelo usado para simulação de abalos sísmicos, o qual gerará o comportamento anômalo. 


\section{Movimento Browniano e Modelagem da Dinâmica do Citoesqueleto}

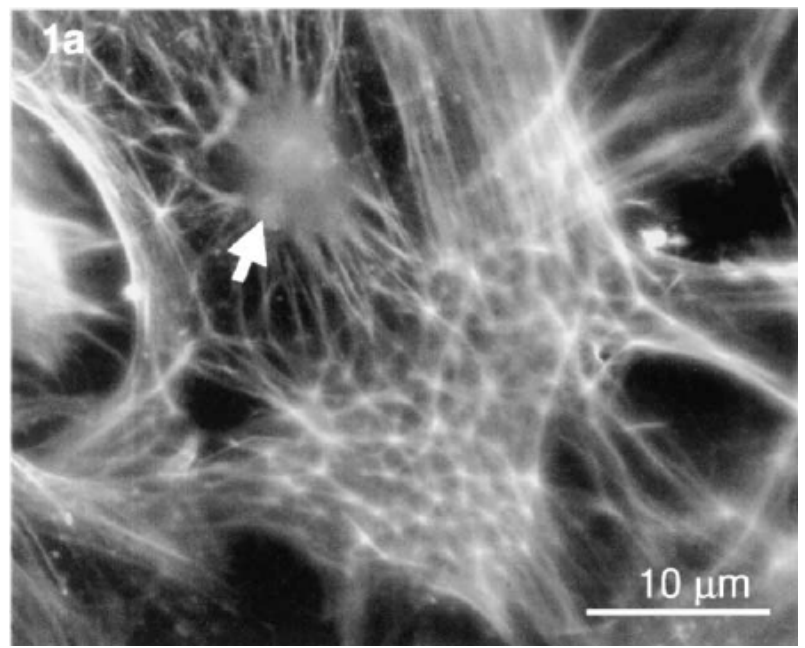

Figura 7.1-5. Microesfera recoberta por RGD anexado ao citoesqueleto [19]. Imagem feita com microscopia eletrônica de varredura.

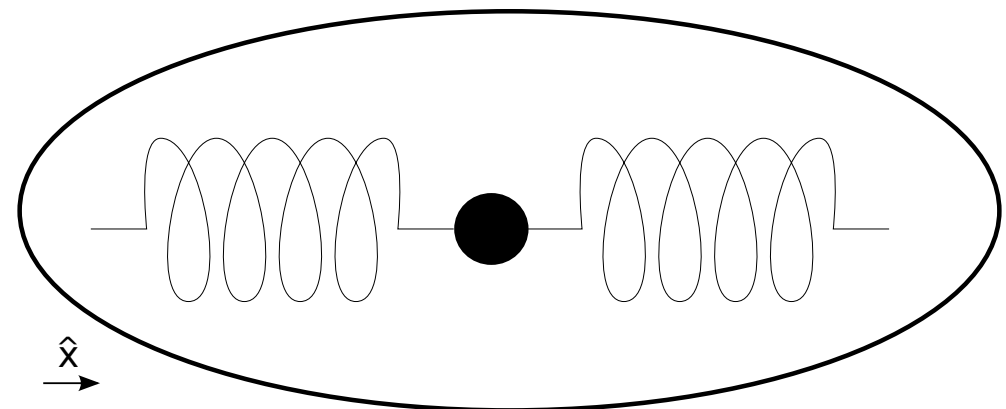

Figura 7.1-6. Esquema de uma microesfera na célula, onde as ligações com as fibras de estresse são representadas por molas.

\subsection{Movimento Browniano e Sistemas Massa-Mola}

Como comentado anteriormente, $\mathrm{MB}$ associado a sistemas massa-mola podem reproduzir de maneira satisfatória o que é observado experimentalmente. Nessa seção será explorado o comportamento de massas conectadas a molas do ponto de vista da dinâmica de Langevin, em uma dimensão. O entendimento do movimento térmico é crucial para a mecânica celular e molecular [40]. As reações químicas responsáveis pelos processos biológicos têm energias que são apenas pouco maiores que a energia térmica. Assim os movimentos difusivos são grandes quando comparados com os direcionados [40]. 


\section{Movimento Browniano e Modelagem da Dinâmica do Citoesqueleto}

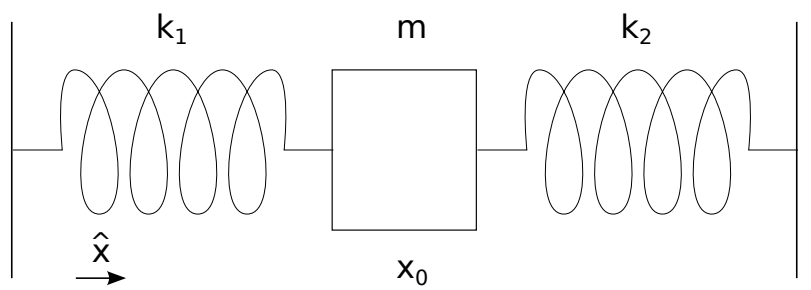

Figura 7.2-7. Sistema mola-massa-mola, onde $x_{0}$ é posição de equilíbrio, $m$ é a massa e $k_{1}$ e $k_{2}$ são as constantes da mola.

\subsubsection{Sistemas Massa-Mola}

Para o sistema experimental em questão, têm-se as microesferas conectadas com as fibras de estresse. As fibras, então, podem ser representadas por molas, e nas subseções seguintes duas situações possíveis são mostradas. Primeiramente um sistema massa-mola-massa, ver Fig. 7.27. Este caso é equivalente a se ter uma fibra em cada lado da microesfera. Realisticamente, como pode ser observado na Fig. 7.1-5, diversas fibras se conectam à microesfera. Assim, o segundo caso mostrado é um sistema com molas em paralelo, ver Fig. 7.2-8, representando diversas fibras.

O objetivo das Seções 7.2.1.1 e 7.2.1.2 é unicamente demonstrar que independente do arranjo das molas, a constante de mola efetiva será simplesmente a soma de todos as constantes individuais.

\subsubsection{Sistema Mola-Massa-Mola}

Considerando uma massa $m$ entre duas molas anexadas à parede, com constantes da mola $k_{1} \mathrm{e}$ $k_{2}$ e $x$ de equilíbrio dado por $x_{0}$, ver Fig.7.2-7. Um deslocamento da massa por uma distância $x$ resulta num alongamento da primeira mola de $x$ (empurrando na mesma direção $-\hat{x}$ ), enquanto que a segunda mola é comprimida por uma distância $x$ (empurrando na mesma direção $-\hat{x}$ ). Dessa maneira, a equação do movimento é dada por: 


\section{Movimento Browniano e Modelagem da Dinâmica do Citoesqueleto}

(A)

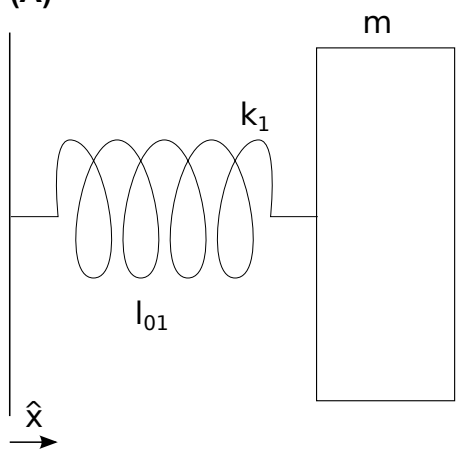

(B)

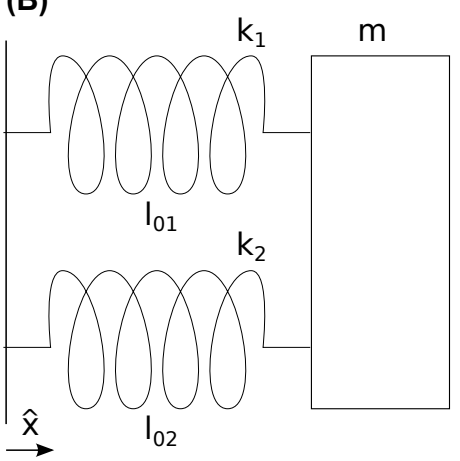

Figura 7.2-8. Sistemas massa-mola. (A) Sistema mola-massa, onde $m$ é a massa, $k_{1}$ é a constante da mola e $l_{01}$ é o comprimento de repouso da mola. (B) Sistema com molas em paralelo, onde $m$ é a massa, $k_{1}$ e $k_{2}$ são as constantes das molas e $l_{01}$ e $l_{02}$ são os comprimentos de repouso das molas.

$$
\begin{array}{r}
m \ddot{x}=-k_{1}\left(x-x_{0}\right)-k_{2}\left(x-x_{0}\right)=-\left(k_{1}+k_{2}\right)\left(x-x_{0}\right) \\
m \ddot{x}=-\left(k_{1}+k_{2}\right)\left(x-x_{0}\right) \\
m \ddot{x}=-k_{\mathrm{ef}} \Delta x,
\end{array}
$$

onde $\Delta x=x-x_{0}$ e a constante efetiva da mola do sistema é dada por $k_{\text {ef }}=k_{1}+k_{2}$.

\subsubsection{Sistema Massa-Mola em Paralelo}

Considerando agora um sistema massa-mola simples, como mostrado na Fig. 7.2-8 (A), tem-se que a força que atua na massa é:

$$
F=-k_{1}\left(x-l_{01}\right)
$$

Agora, com duas molas em paralelo, ver Fig. 7.2-8(B), fica-se com:

$$
F=-k_{1}\left(x-l_{01}\right)-k_{2}\left(x-l_{02}\right)
$$


o que resulta em:

$$
F=-k_{\mathrm{ef}}\left(x-l_{0 \mathrm{ef}}\right)
$$

onde:

$$
\left\{\begin{array}{l}
k_{\mathrm{ef}}=k_{1}+k_{2} \\
l_{0 \mathrm{ef}}=\frac{k_{1} l_{01}+k_{2} l_{02}}{k_{1}+k_{2}} .
\end{array}\right.
$$

Desta maneira, dado o conjunto de molas, pode-se achar o $k_{\text {ef }}$ e a posição de equilíbrio resultante.

\subsubsection{Movimento Browniano Superamortecido em um Poço de Potencial Tipo Mola}

Um ruído térmico pode ser associado ao sistema massa-mola para representar a microesfera ligada a fibras de estresse. Como visto na Seção 7.2.1, tendo molas lateralmente na massa, ou em paralelo, o $k_{\text {ef }}$ será simplesmente a soma de todos os $k$ s individuais de cada mola. Assim, o conjunto de fibras de estresse pode ser representado por uma fibra com uma constante efetiva relativa ao conjunto.

A microesfera se conecta ao CSK e se move a medida que o CSK se move, ou seja, o movimento da microesfera é governado pelo movimento do CSK. As proteínas do CSK são muito pequenas, ver Seção 1.3, o que leva as forças inerciais serem pequenas também [40]. As forças viscosas do fluido ao redor são grandes comparadas às inerciais, consequentemente as proteínas relaxam monotonicamente para novas conformações [40]. Assim, a movimentação global das proteínas é superamortecida, e pode ser usualmente ignorada.

Considerando o que foi discutido no parágrafo anterior, a equação de Langevin para um MB 
superamortecido num potencial tipo mola é dada por:

$$
\frac{d x}{d t}=-k^{\prime} x+F(t)
$$

$\operatorname{com} x(0)=x_{0}, k^{\prime}=k_{\text {ef }} / \alpha$ e a $F(t)$ dada por:

$$
\left\{\begin{aligned}
\langle F(t)\rangle & =0 \\
\left\langle F(t) F\left(t^{\prime}\right)\right\rangle & =2 D \delta\left(t-t^{\prime}\right) .
\end{aligned}\right.
$$

Pode-se escrever que:

$$
x(t)=y(t) e^{-k^{\prime} t}
$$

onde $y(t)$ deve ser determinada.

Substituindo na equação 7.11, tem-se:

$$
\begin{array}{r}
\frac{d}{d t}\left[y(t) e^{-k^{\prime} t}\right]=-k^{\prime} y e^{-k^{\prime} t}+F(t) \\
\frac{d y}{d t} e^{-k^{\prime} t}+y e^{-k^{\prime} t}\left(-k^{\prime}\right)=-k^{\prime} y e^{-k^{\prime} t}+F(t) \\
\frac{d y}{d t}=e^{k^{\prime} t} F(t) \\
y=y_{0}+\int_{0}^{t} e^{k^{\prime} t^{\prime}} F\left(t^{\prime}\right) d t^{\prime}
\end{array}
$$

onde $y_{0}=x_{0}$. Voltando: 


$$
\begin{array}{r}
x(t)=y(t) e^{-k^{\prime} t} \\
=y_{0} e^{-k^{\prime} t}+e^{-k^{\prime} t} \int_{0}^{t} e^{k^{\prime} t^{\prime}} F\left(t^{\prime}\right) d t^{\prime} \\
=x_{0} e^{-k^{\prime} t}+e^{-k^{\prime} t} \int_{0}^{t} e^{k^{\prime} t^{\prime}} F\left(t^{\prime}\right) d t^{\prime} .
\end{array}
$$

Considerando $x_{0}=0$, obtem-se então que:

$$
x(t)=e^{-k^{\prime} t} \int_{0}^{t} e^{k^{\prime} t^{\prime}} F\left(t^{\prime}\right) d t^{\prime} .
$$

Pode-se então calcular o correlator, que será útil para o cálculo do MSD:

$$
\begin{array}{r}
c(\tau)=\langle\vec{x}(\tau) \vec{x}(0)\rangle \\
\int_{-\infty}^{\tau} d t_{1} \int_{-\infty}^{0} d t_{2} e^{-k^{\prime}\left(\tau-t_{1}-t_{2}\right)}\left\langle\vec{F}\left(t_{1}\right) \vec{F}\left(t_{2}\right)\right\rangle \\
\int_{-\infty}^{\tau} d t_{1} \int_{-\infty}^{0} d t_{2} e^{-k^{\prime}\left(\tau-t_{1}-t_{2}\right)} 2 D \delta\left(t_{1}-t_{2}\right) \\
2 D \int_{-\infty}^{0} d t_{2} \int_{-\infty}^{\tau} d t_{1} e^{-k^{\prime}\left(\tau-t_{1}-t_{2}\right)} 2 D \delta\left(t_{1}-t_{2}\right) \\
2 D \int_{-\infty}^{0} d t_{2} e^{-k\left(\tau-2 t_{2}\right)} \\
2 D e^{-k^{\prime} \tau} \int_{-\infty}^{0} d t_{2} e^{k^{\prime} 2 t_{2}} \\
\frac{2 D e^{-k^{\prime} \tau}}{2 k^{\prime}} e^{2 k^{\prime} t_{2}} /{ }_{-\infty} \\
\frac{D}{k^{\prime}} e^{-k^{\prime} \tau} .
\end{array}
$$

Portanto:

$$
\langle\vec{x}(\tau) \vec{x}(0)\rangle=\frac{D}{k^{\prime}} e^{-k^{\prime} \tau}
$$




\section{Movimento Browniano e Modelagem da Dinâmica do Citoesqueleto}

Agora pode-se calcular o MSD da seguinte maneira:

$$
\begin{array}{r}
\Delta \vec{x}^{2}(\tau)=\left\langle[\vec{x}(\tau)-\vec{x}(0)]^{2}\right\rangle \\
=\left\langle x^{2}(\tau)\right\rangle+\left\langle x^{2}(0)\right\rangle-2\langle\vec{x}(\tau) \vec{x}(0)\rangle \\
=2\left[\left\langle x^{2}\right\rangle-\langle\vec{x}(\tau) \vec{x}(0)\rangle\right] \\
=\frac{2 D}{k^{\prime}}\left(1-e^{-k^{\prime} \tau}\right) .
\end{array}
$$

Portanto:

$$
\overrightarrow{\Delta x^{2}}(\tau)=\frac{2 D}{k^{\prime}}\left(1-e^{-k^{\prime} \tau}\right)
$$

Neste momento pode-se definir o tempo de relaxação $\tau_{0}$ como:

$$
\tau_{0}=\frac{1}{k^{\prime}}
$$

Para tempos muito menores que o tempo de relaxação, $t<<\tau_{0}$, a função exponencial pode ser expandida, no caso até primeira ordem em $t$, resultando:

$$
\left\langle\Delta x^{2}(t \rightarrow 0)\right\rangle=-2 k^{\prime} x_{0}^{2} t+2 D t
$$

Considerando $x_{0}=0$, pode-se ver que a força elástica não exerce influência na partícula, e esta se difunde livremente com coeficiente de difusão $D$.

Para o limite de tempo longo, $t \rightarrow \infty$, encontra-se que:

$$
\begin{array}{r}
\langle x(t \rightarrow \infty)\rangle=0 \\
\left\langle x^{2}(t \rightarrow \infty)\right\rangle=2 \frac{D}{k^{\prime}} .
\end{array}
$$

O deslocamento quadrático médio para um MB confinado num poço de potencial tipo mola, 


\section{Movimento Browniano e Modelagem da Dinâmica do Citoesqueleto}

para tempos longos, converge para um platô de constante dada pela Eq. 7.39. Pode-se chamar esse valor de um raio limitante, dado por $R_{l}=\sqrt{\frac{2 k_{B} T}{k_{1}+k_{2}}}$.

\subsubsection{Simulação Numérica}

Para a simulação numérica, tem-se que:

$$
\frac{d x}{d t}=-\frac{k_{\mathrm{ef}}}{\alpha} \Delta x+\xi(t)
$$

com

$$
\left\{\begin{aligned}
\langle\xi(t)\rangle & =0 \\
\left\langle\xi(t) \xi\left(t^{\prime}\right)\right\rangle & =2 D \delta\left(t-t^{\prime}\right),
\end{aligned}\right.
$$

Fazendo a discretização dessa equação, fica-se com:

$$
x_{i}=x_{i-1}-\frac{k_{\mathrm{ef}}}{\alpha} \Delta t\left(x_{i-1}-x_{0}\right)+\xi_{i},
$$

onde $\xi_{i}$ são números independentes Gaussianos com média zero e variância igual a $2 D \Delta t$.

O tamanho do passo temporal pode ser restringido por possíveis instabilidades numéricas [71]. Para constantes da mola $k>>1$, o algoritmo é numericamente estável somente se $k \Delta t / \alpha<1$ [71]. Dessa maneira, tem-se um critério para a escolha da constante da mola e o passo temporal.

Para uma simulação foram escolhidos os seguintes parâmetros: $\Delta t=10^{-2}, k_{B} T=1$, $\alpha=1, k_{\mathrm{ef}}=1, D=1, x_{0}=0$ e $x_{\mathrm{in}}=0$, onde $x_{0}$ é o $x$ de equilíbrio da mola e $x_{\mathrm{in}}$ é o $x$ inicial. Para um total de 100000 passos, o MSD calculado a partir dos $x$ 's obtidos pela simulação e o MSD obtido analiticamente, Eq. 7.35, estão mostrados na Fig. 7.2-9. 


\section{Movimento Browniano e Modelagem da Dinâmica do Citoesqueleto}

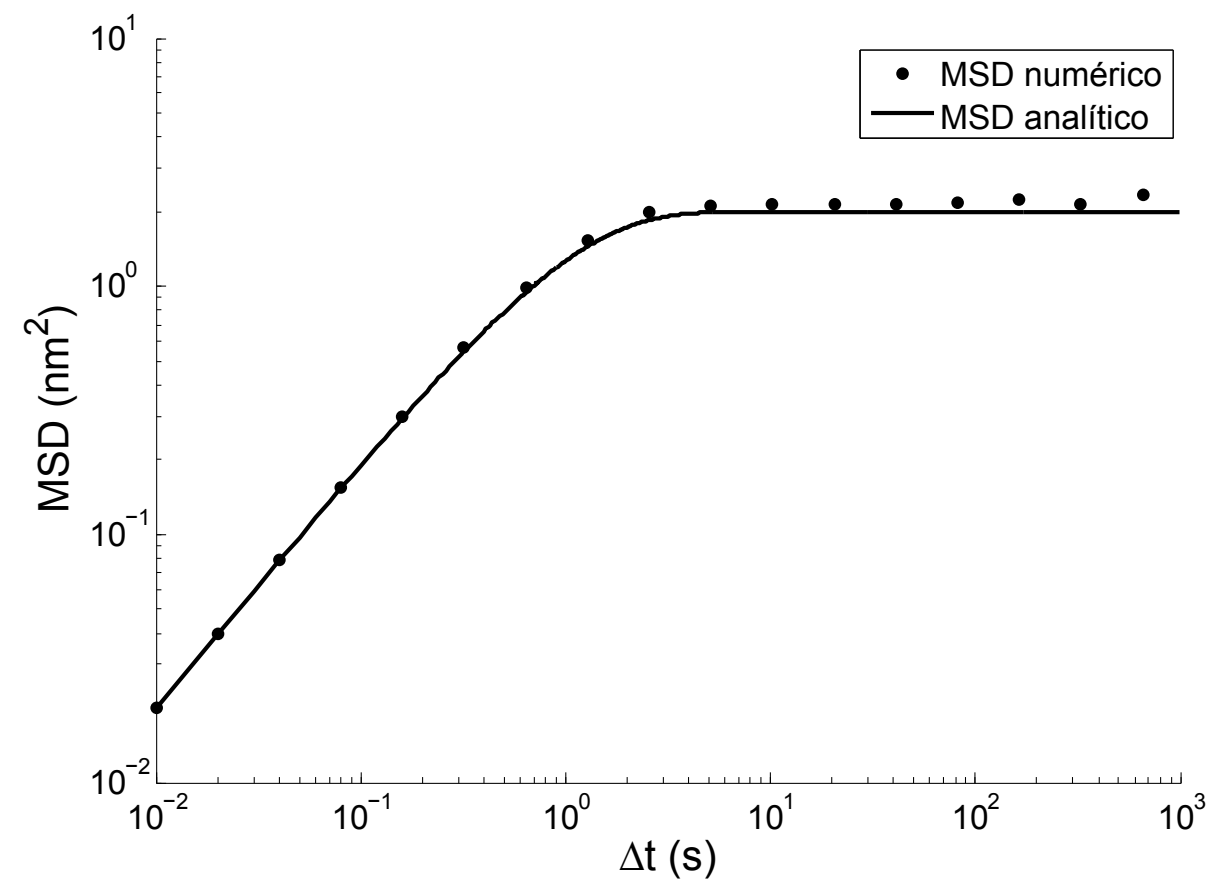

Figura 7.2-9. Resultado do MSD para a simulação do sistema massa-mola descrito na Seção 7.2.2. Os pontos são o MSD calculado a partir da simulação, com os parâmetros mostrados na Seção 7.2.2.1; e a linha contínua, o MSD analítico calculado a partir da Eq. 7.35.

\subsection{Modelagem do Citoesqueleto}

Para a modelagem do CSK será utilizado basicamente o sistema descrito na Seção 7.2.2. Primeiramente haverá uma discussão acerca dos parâmetros. A idéia é a utilização de parâmetros que descrevam os valores reais encontrados nos experimentos, Seção 7.3.1. A partir daí a modelagem será feita em etapas. Primeiramente será feita a simulação do potencial tipo mola com os parâmetros escolhidos, Seção 7.3.2, depois com o conjunto se movendo, Seção 7.3.3. A próxima etapa será a inclusão do modelo de blocos deslizantes para a inserção dos saltos anômalos, Seção 7.4. Todas as modelagens foram feitas em uma dimensão. 


\subsubsection{Parâmetros Básicos para a Modelagem}

Todos os parâmetros da Eq. 7.11 devem ser encontrados de maneira a gerar resultados semelhantes aos encontrados experimentalmente. Assim, para o cálculo de $\alpha$ e $D$, ver Eqs. A.42 e A.43, foi usado o diâmetro da microesfera igual a $4.5 \mu \mathrm{m}, k_{B}=1.38 \cdot 10^{-23} \mathrm{~m}^{2} \cdot \mathrm{kg} \cdot \mathrm{s}^{-2} \cdot \mathrm{K}^{-1}, T=$ $30^{\circ} \mathrm{C}$ e $\eta=1.4 \mathrm{~Pa} \cdot \mathrm{s}[19]$. Assim, encontra-se que $\alpha=5.9 \cdot 10^{-5} \mathrm{~Pa} \cdot \mathrm{s} \cdot \mathrm{m}$, e $D=7 \cdot 10^{-17} \mathrm{~m}^{2} / \mathrm{s}$. A estimativa do $k_{\text {ef }}$ é mais complicada e é discutida a seguir.

$\mathrm{O}$ conjunto de fibras ligado à microesfera resulta num potencial tipo mola. A força em cada fibra é gerada ao longo de sua direção, de onde pode-se associar seu módulo elástico com a constante da mola da fibra. Sabe-se que o módulo elástico é dado por: $E=\sigma / \epsilon$, onde $\sigma$ é a tensão aplicada e $\epsilon$ é a deformação elástica sofrida. A tensão é força por área e a deformação elástica é a variação no comprimento relativo ao inicial. Desta maneira:

$$
\begin{array}{r}
E=\frac{\sigma}{\epsilon}=\frac{F / A}{\Delta l / l_{0}}=\frac{F l_{0}}{A \Delta l} \\
F=A E \frac{\Delta l}{l_{0}}=k \Delta l \\
k=\frac{A E}{l_{0}},
\end{array}
$$

de onde encontra-se o $k$ de cada fibra em função do módulo elástico $E$, o comprimento de repouso $l_{0}$ e a área da fibra $A=\pi r^{2}$. Considerando dados encontrados na literatura, tem-se que $E=100 \mathrm{kPa}$ [69], $r=0.15 \mu \mathrm{m}$ [69] e $l_{0}$ varia de 5 a $25 \mu \mathrm{m}[69,72]$. De onde se conclui que $k=7.1 / l_{0} \mathrm{nN} / \mu \mathrm{m}$.

As quantidades de ligações feitas serão limitadas pelas quantidades de receptores de integrina disponíveis, e RGD na microesfera. Sabe-se que uma célula tem em torno de 5.000 integrinas por $\mu \mathrm{m}^{2}$ [73] e a densidade de RGD é em torno de 1 por $2 \mathrm{~nm}^{2}$ de área da superfície da microesfera [74]. A parte da integrina que se encontra fora da membrana celular tem uma 


\section{Movimento Browniano e Modelagem da Dinâmica do Citoesqueleto}

cabeça ativa de em torno de $10 \mathrm{~nm}$ de diâmetro $[75,76]$. Esses valores serão os limitantes para a quantidade de ligação formada em cada microesfera.

Para a modelagem, a maneira mais simples e direta de se encontrar o valor do $k_{\mathrm{ef}}$ é comparar os dados experimentais com o modelo teórico. Neste caso, como visto na Seção 7.2.2, para o sistema massa-mola é possível encontrar um platô no MSD que é dado por $R_{l}=\sqrt{\frac{2 k_{B} T}{k_{\mathrm{ef}}}}$, como visto na Fig. 7.2-9. Desta maneira:

$$
k_{\mathrm{ef}}=\frac{2 k_{B} T}{R_{l}^{2}} .
$$

Assim, os valores dos $R_{l}$ s encontrados experimentalmente podem ser usados para se estimar o $k_{\text {ef }}$.

Olhando os gráficos dos MSDs do Capítulo 6, por exemplo, pode-se observar que os $R_{l}^{2} \mathrm{~s}$ ficam em torno de $10^{2}$ e $10^{3} \mathrm{~nm}^{2}$. Considerando que também tenha um ruído adicionado a essa medida, e que este esteja quase da ordem de grandeza do próprio MSD, pode-se dizer que o $R_{l}^{2}$ estaria da ordem de $1 \mathrm{~nm}^{2}$. Calculando então os $k_{\mathrm{ef}} \mathrm{s}$ para $R_{l}^{2}=10,1 \mathrm{e} 10^{-1} \mathrm{~nm}^{2}$, obtêm-se os valores de $0.84,8.36$ e $83.63 \mathrm{nN} / \mu \mathrm{m}$.

Agora, para se estimar a quantidade de ligações, levando em consideração que o $k_{\text {ef }}$ é a soma de todos os $k \mathrm{~s}$, como explicado na Seção 7.2.1, foram escolhidas números de ligações variando entre 2 e 128 e, a partir da Eq. 7.45, foi-se estimado o $k_{\text {ef }}$. Para isso foram utilizados os valores extremos de $l_{0}$ e $l_{0}$ variando sob uma distribuição uniforme entre os valores extremos. Os valores encontrados estão descritos na Tab. 7.1.

Pode-se supor que usando os valores de $l_{0} \mathrm{~s}$ aleatórios é possível encontrar valores mais realísticos, pois com certeza as fibras de estresses conectadas às microesferas não seriam todas do mesmo tamanho. Considerando então o $l_{0}$ dado aleatoriamente, a partir dos valores mostrados na Tab. 7.1, pode-se ver que para $R_{l}^{2}$ em torno de $1 \mathrm{~nm}^{2}$, a microesfera tem em torno de 16 ligações. Isso está coerente com o que é observado na Fig. 1.4-6 b, de onde pode-se observar um 


\section{Movimento Browniano e Modelagem da Dinâmica do Citoesqueleto}

\begin{tabular}{cccc}
\hline Total de ligações & $k_{\text {ef }}$ para $l_{0}=5 \mu \mathrm{m}$ & $k_{\text {ef }}$ para $l_{0}=25 \mu \mathrm{m}$ & $k_{\text {ef }}$ para $l_{0}$ aleatório \\
\hline 2 & 2.84 & 0.57 & 1.36 \\
4 & 5.68 & 1.14 & 2.60 \\
8 & 11.36 & 2.27 & 3.56 \\
16 & 22.72 & 4.54 & 8.43 \\
32 & 45.44 & 9.09 & 19.90 \\
64 & 90.88 & 18.18 & 35.95 \\
128 & 181.76 & 36.35 & 71.29 \\
\hline \hline
\end{tabular}

Tabela 7.1. Valores de $k_{\text {ef }}$ em nN/ $\mu$ m encontrados para diversos valores totais de ligações e para todos os $l_{0}$ iguais a $5 \mu \mathrm{m}$ ou $25 \mu \mathrm{m}$, ou distribuídos uniformemente entre 5 e $25 \mu \mathrm{m}$.

número de ligações similar, ou da mesma ordem de grandeza, ao encontrado aqui.

Esses são os parâmetros básicos para a simulação. Outros necessários que possam surgir mais à frente, serão discutidos posteriormente.

\subsubsection{Difusão em um Potencial Tipo Mola}

Com os parâmetros escolhidos na seção anterior, a simulação do sistema massa-mola, descrita na Seção 7.2.2, foi refeita. O intevalo de tempo escolhido foi $\Delta t=10^{-4} \mathrm{~s}$.

O MSD encontrado para essa simulação está mostrado na Fig. 7.3-10. Pode-se observar que a partir de um tempo $\tau_{0}$, o MSD alcança um topo como esperado. Os valores esperados analiticamente para $\tau_{0}$ e o $R_{l}^{2}$ são: $7.1 \cdot 10^{-3}$ s e $1 \mathrm{~nm}^{2}$.

\subsubsection{Difusão em um Potencial Tipo Mola Caminhante}

Na seção anterior foi descrito como seria a difusão da microesfera em um potencial tipo mola com parâmetros reais. Agora, para melhor descrever o que acontece em uma célula, o conjunto microesfera mais molas irá se mover, ou seja, o poço de potencial formado pelas forças elásti- 


\section{Movimento Browniano e Modelagem da Dinâmica do Citoesqueleto}

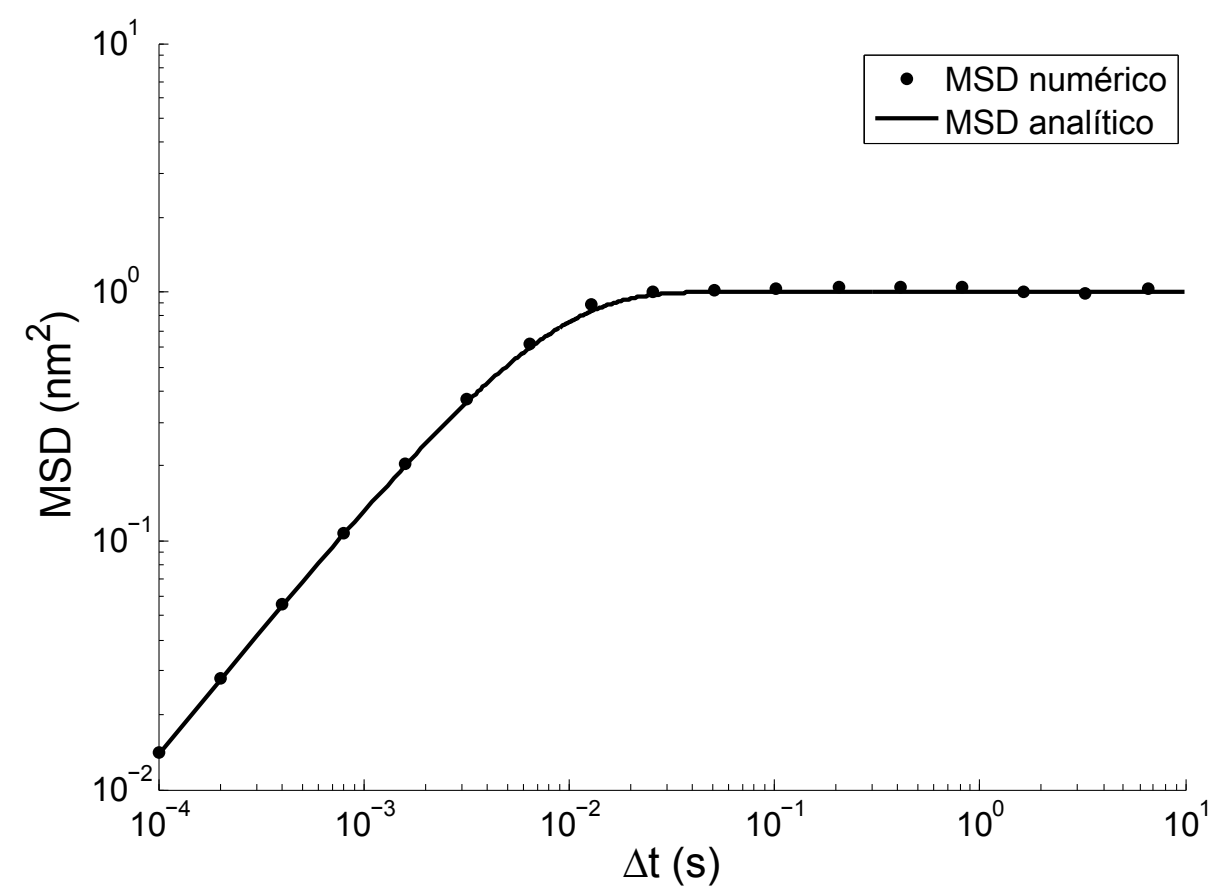

Figura 7.3-10. MSD calculado numericamente a partir dos parâmetros descritos na Seção 7.3.1, pontos. A linha contínua é o MSD calculado analiticamente.

cas deve ter uma velocidade. Essa movimentação do poço de potencial vem de várias fontes, como por exemplo o movimento das fibras de actina durante movimentos celulares, contração e também da polimerização e despolimerização dos próprios filamentos de actina.

Para determinar a velocidade do poço, um experimento de difusão realizado no LabM $^{2}$ foi analisado e encontrada a velocidade média da microesfera. Para um experimento com 19 microesferas de látex, usando magnificação de $40 \times$, 300 s e frequência de 10 fps, encontrou-se uma velocidade média $v_{m}=0.27 \mathrm{~nm} / \mathrm{s}$, com desvio $v_{d}=51.65 \mathrm{~nm} / \mathrm{s}$. Essa nova informação foi adicionada ao $x_{\text {eq }}$, ficando com: $x_{\text {eq }}=v_{m} \cdot t$, onde $t$ é o tempo decorrido. Assim, as novas equações para a simulação são:

$$
\frac{d x}{d t}=-\frac{k_{\mathrm{ef}}}{\alpha}\left(x-v_{m} t\right)+\xi(t)
$$


Movimento Browniano e Modelagem da Dinâmica do Citoesqueleto

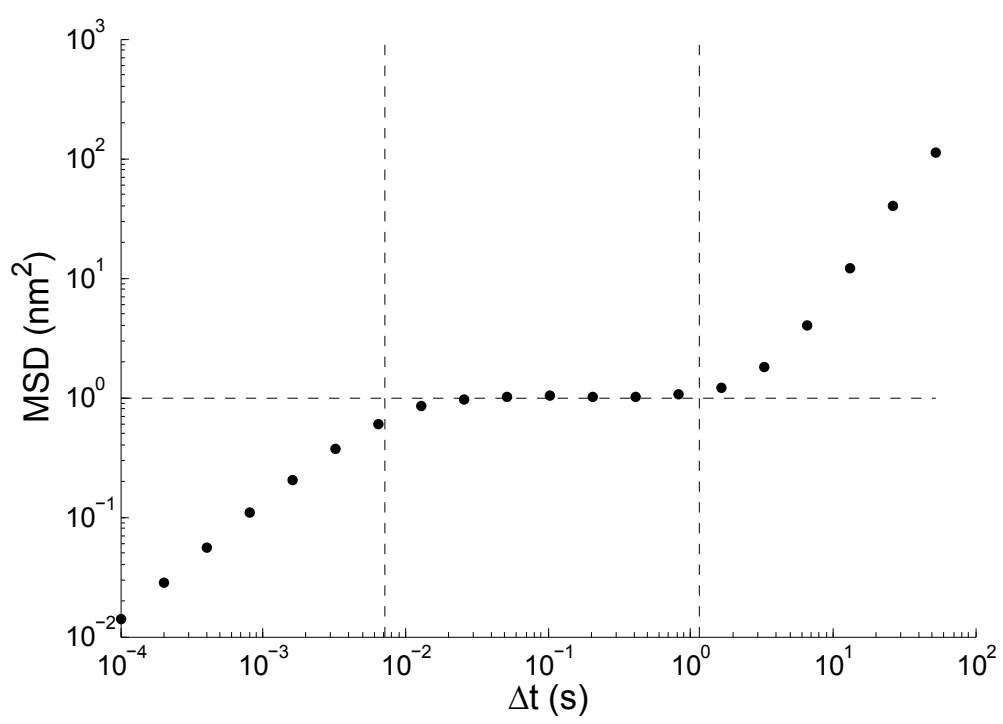

Figura 7.3-11. MSD calculado numericamente. A linha pontilhada horizontal indica $R_{l}^{2}$, enquanto que as verticais indicam $\tau_{0}$ e $\tau_{1}$.

com

$$
\left\{\begin{aligned}
\langle\xi(t)\rangle & =0 \\
\left\langle\xi(t) \xi\left(t^{\prime}\right)\right\rangle & =2 D \delta\left(t-t^{\prime}\right)
\end{aligned}\right.
$$

Discretizando fica-se com:

$$
x_{i}=x_{i-1}-\frac{k_{\mathrm{ef}}}{\alpha} \Delta t\left(x_{i-1}-v_{m} t_{i}\right)+\xi_{i}
$$

onde $\xi_{i}$ são números independentes Gaussianos com média zero e variância igual a $2 D \Delta t$, e $t_{i}$ é o tempo no passo $i$. Usando então os mesmos parâmetros da seção 7.3.2, foi encontrado o MSD mostrado na Fig. 7.3-11.

O movimento do poço terá um efeito significante na partícula presa, no caso a microesfera, no poço somente para tempos $t$ longos o suficiente, $t>\tau_{1}$. O valor de $\tau_{1}$ pode ser estimado 


\section{Movimento Browniano e Modelagem da Dinâmica do Citoesqueleto}

igualando a distância $v_{m} \cdot \tau_{1}$ com o raio limitante $R_{l}$ definido na seção 7.2.2. Assim:

$$
\begin{array}{r}
v_{m} \tau_{1}=R_{l} \\
\tau_{1}=\frac{R_{l}}{v_{m}} \\
\tau_{1}=\sqrt{\frac{2 D}{k^{\prime}}} \frac{1}{v_{m}} \\
\tau_{1}=\sqrt{\frac{2 D \alpha}{k_{\mathrm{ef}}}} \frac{1}{v_{m}} .
\end{array}
$$

Observando a Fig. 7.3-11, pode-se dizer que existem 3 regimes delimitado por $\tau_{0}$ e $\tau_{1}$, onde $\tau_{0}=\alpha / k_{\text {ef }}$ definido na Seção 7.2.2. Calculando esses valores, foi encontrado que: $\tau_{0}=7.1$. $10^{-3} \mathrm{~s}, \tau_{1}=1.2 \mathrm{~s}$ e $R_{l}^{2}=1 \mathrm{~nm}^{2}$. Assim, para $t<\tau_{0}$ a partícula se move livremente dentro do poço de potencial. Para $\tau_{0}<t<\tau_{1}$, tem-se um confinamento elástico, onde a partícula se encontra presa no poço de potencial. E para $t>\tau_{1}$, o movimento do poço começa a ter um papel importante, juntamente com outros movimentos, como o movimento da própria célula.

O histograma dos $Z$ s está mostrado na Fig. 7.3-12. Embora o MSD da simulação tenha semelhanças ao encontrado experimentalmente, o histograma de $Z$ não apresenta os eventos anômalos esperados. Desta maneira, para se obter uma simulação mais realística, na próxima seção o modelo de blocos deslizantes, Seção 7.4, será adicionado ao modelo usado nesta seção. Espera-se obter os eventos anômalos e que a simulação tenha uma dinâmica mais realística.

\subsection{Modelo de Blocos Deslizantes}

O modelo de Turcotte [70], ou modelo de blocos deslizantes, foi desenvolvido para estudos de abalos sísmicos. Há diversas variações desse modelo sendo o mais simples formado por um sistema massa mola como mostrado na Fig. 7.4-13. Neste modelo, o bloco de massa $m$ é 


\section{Movimento Browniano e Modelagem da Dinâmica do Citoesqueleto}

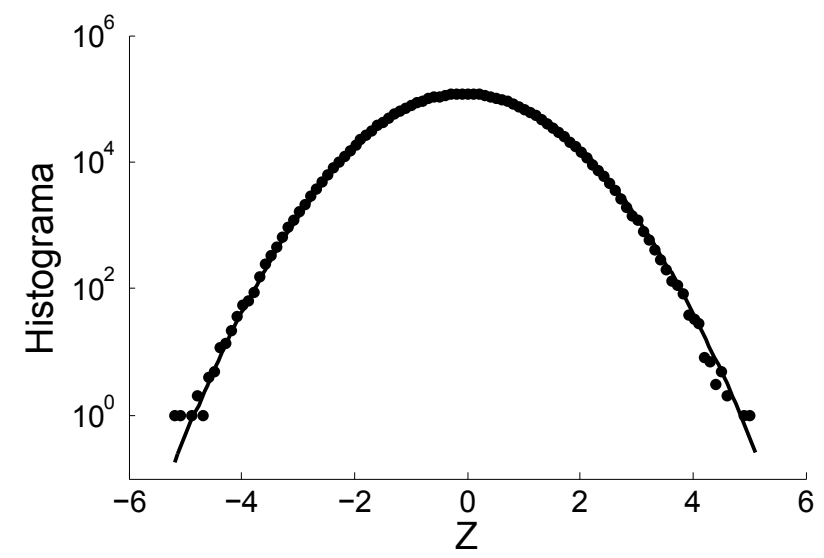

Figura 7.3-12. Histograma dos $Z$ s referente a simulação. A linha contínua é o ajuste Gaussiano do tipo $a e^{-x^{2} / 2 \sigma^{2}}$, com parâmetros $a=119000$ e $\sigma=1.00$.

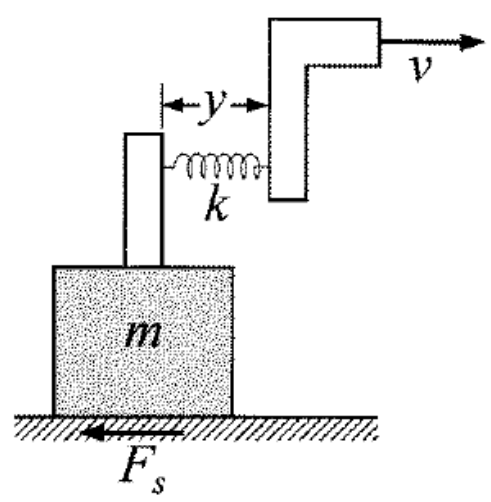

Figura 7.4-13. Modelo de bloco deslizante constituido de um único bloco de massa $m$ puxado sobre uma superfície por uma placa condutora com uma velocidade constante $v$. A placa é conectada ao bloco por uma mola com constante da mola $k$. O movimento será restringido por uma força de atrito $F_{s}$ [70].

puxado sobre uma superfície por uma placa condutora com velocidade constante $v$. A placa é conectada ao bloco por uma mola com constante $k$. O movimento será restringido por uma força de atrito $F_{s}$ [70].

Supondo a mola em repouso, $y_{0}$ é a posição onde a mola está presa na massa e $y_{1}$ é a posição onde a mola está presa na placa condutora, resultando em $y=y_{1}-y_{0}$. As equações do modelo 
podem ser escritas como:

$$
\begin{aligned}
& \left\{\begin{aligned}
m \ddot{y_{0}}-k\left(y_{1}-y_{0}\right)=-F_{s} & \rightarrow \quad \text { se } \quad\left|-k\left(y_{1}-y_{0}\right)\right|>\left|-F_{s}\right| \\
\ddot{y_{0}}=\dot{y}_{0}=0 \quad & \rightarrow \quad \text { se } \quad\left|-k\left(y_{1}-y_{0}\right)\right| \leq\left|-F_{s}\right|,
\end{aligned}\right. \\
& \left\{\begin{array}{l}
\ddot{y_{1}}=0 \\
\dot{y_{1}}=v \\
y_{1}=y_{10}+v t .
\end{array}\right.
\end{aligned}
$$

Onde $F_{s}$ é a força de atrito dada por $F_{s}=\frac{F_{0}}{1+|\dot{y} / v|}$. Essa força de atrito é conhecida como velocity-weakening friction law e diminui monotonicamente a medida que a velocidade do bloco aumenta [77].

As Eqs. 7.54 e 7.55 podem ser resolvidas numericamente usando, por exemplo, método de Euler. Escolhendo os parâmetros como: $k=10, m=10, v=5, F_{0}=10, \Delta t=0.1 \mathrm{e}$ $N=400$, onde $N$ é o número total de iterações, pode-se fazer uma simulação como exemplo do funcionamento do modelo. Os gráficos encontrados para as posições, velocidades e acelerações, tanto referente às posições $y_{0}$ e $y_{1}$ como referente à posição relativa estão mostrados na Fig. 7.414.

Observando os gráficos encontrados, pode-se ver que o bloco permanece na mesma posição, até que a condição mostrada na Eq. 7.54 seja satisfeita. Aí o mesmo começa a se mover até parar novamente. Como $v$ é constante nesse caso, esse ciclo se repete com o passar das iterações. No caso da simulação do CSK, os picos em y representariam os saltos anômalos observados experimentalmente. Na seção seguinte, esse modelo de blocos deslizantes será adicionado ao modelo para dinâmica do CSK para a obtenção dos movimentos anômalos. 


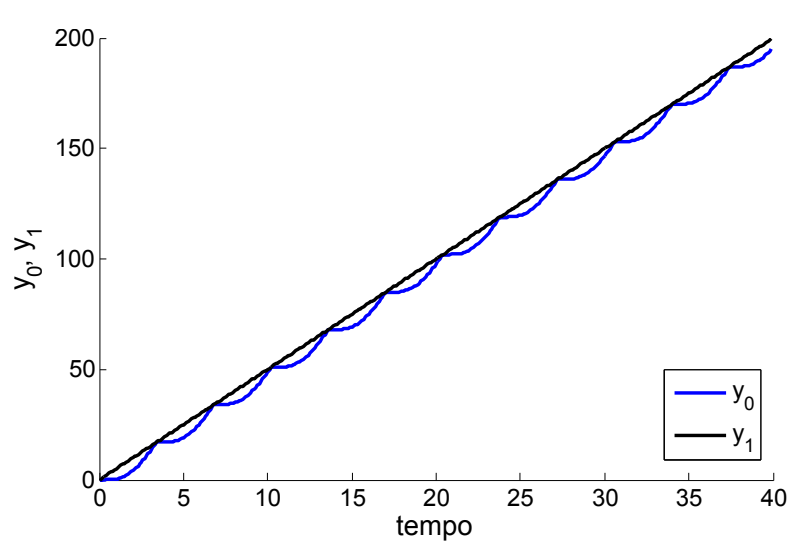

(a)

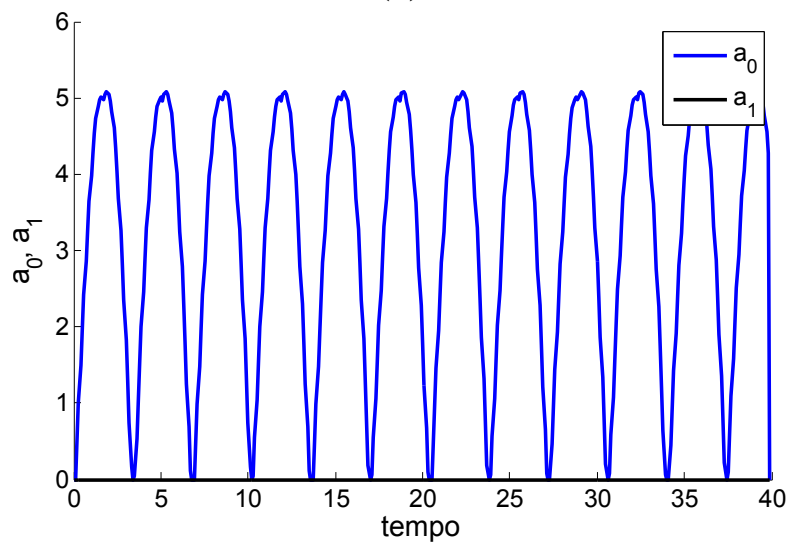

(c)

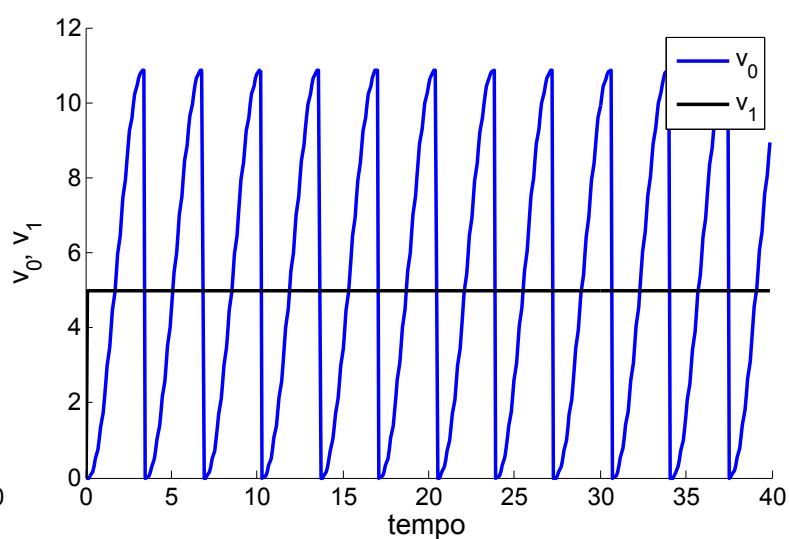

(b)

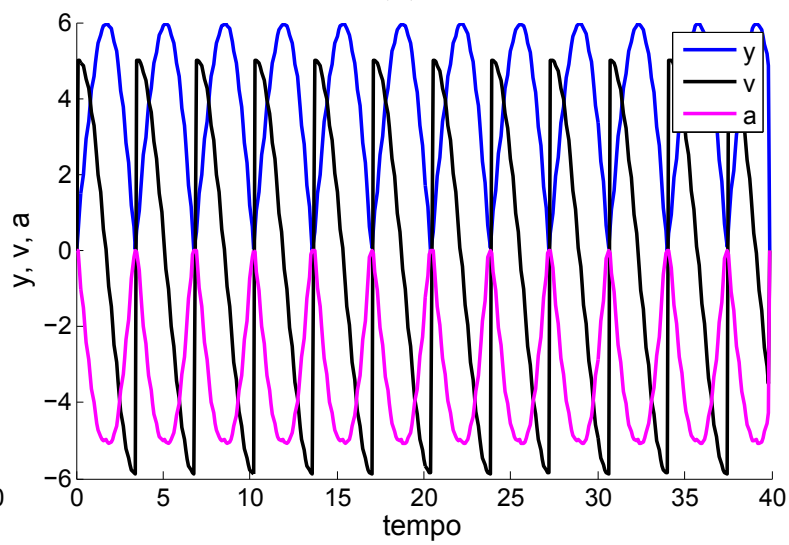

(d)

Figura 7.4-14. Gráficos das posições $y_{0}, y_{1}$ e $y$, e suas respectivas velocidades e acelerações da simulação feita das Eqs. 7.54 e 7.55. Os parâmetros usados foram: $k=10, m=10, v=5, F_{0}=10, \Delta t=0.1 \mathrm{e}$ $N=400$, onde $N$ é o número total de iterações. (a) Gráficos de $y_{0} \mathrm{e} y_{1}$, (b) Gráficos de $v_{0} \mathrm{e} v_{1}$, (c) Gráficos de $a_{0}$ e $a_{1}$ e (d) Gráficos de $y=y_{1}-y_{0}, v=v_{1}-v_{0}$ e $a=a_{1}-a_{0}$.

\subsubsection{Modelagem do Citoesqueleto com Blocos Deslizantes}

A idéia dos blocos deslizantes pode ser inserida no modelo anterior, Seção 7.3, para melhorá-lo na tentativa de inserir os saltos anômalos. Dessa maneira, as novas equações são:

$$
\left\{\begin{aligned}
\frac{d y_{0}}{d t}=\frac{k}{\alpha}\left(y_{1}-y_{0}\right)-\frac{F_{s}}{\alpha}+\xi(t) & \rightarrow \quad \text { se } \quad\left|\frac{k}{\alpha}\left(y_{1}-y_{0}\right)+\xi(t)\right|>\left|\frac{F_{s}}{\alpha}\right| \\
\frac{d y_{0}}{d t}=\xi(t) & \rightarrow \quad \text { se } \quad\left|\frac{k}{\alpha}\left(y_{1}-y_{0}\right)+\xi(t)\right| \leq\left|\frac{F_{s}}{\alpha}\right|
\end{aligned}\right.
$$

onde $y_{1}=y_{10}+v t, y_{0}$ é a posição da microesfera e $\xi(t)$ é o ruído definido como na Seção 7.3. 


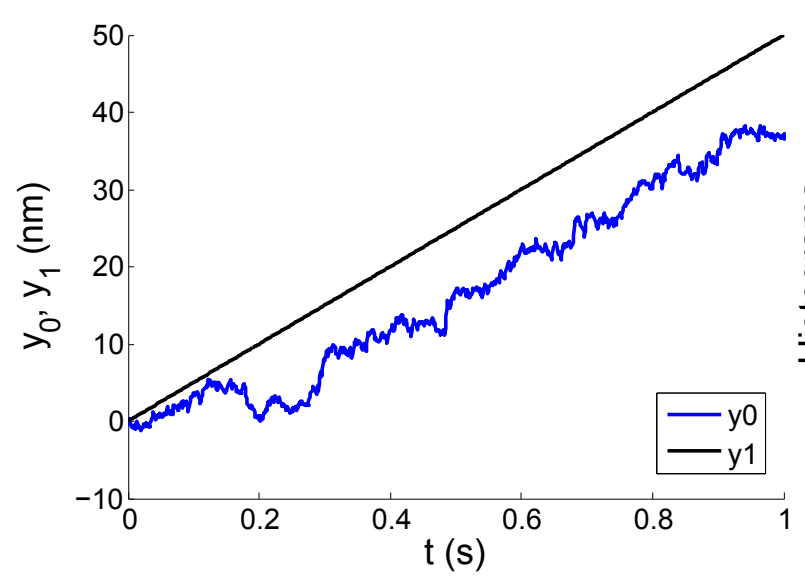

(a)

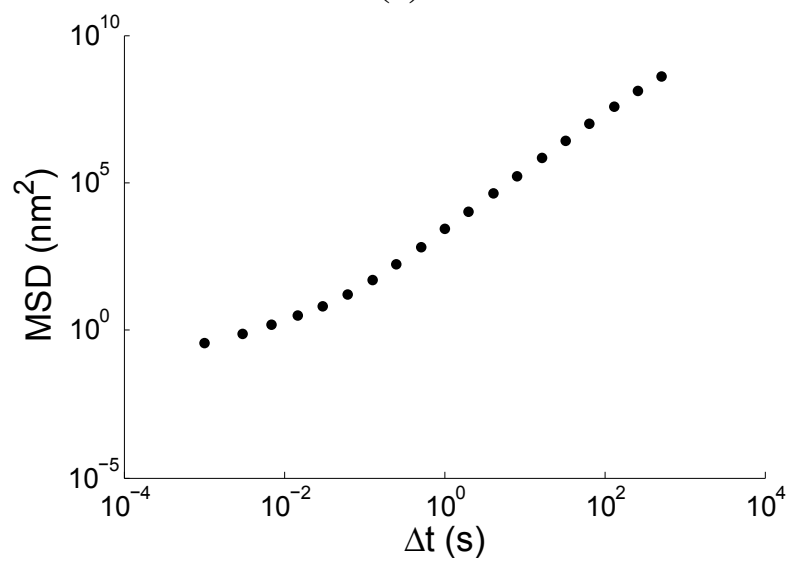

(c)

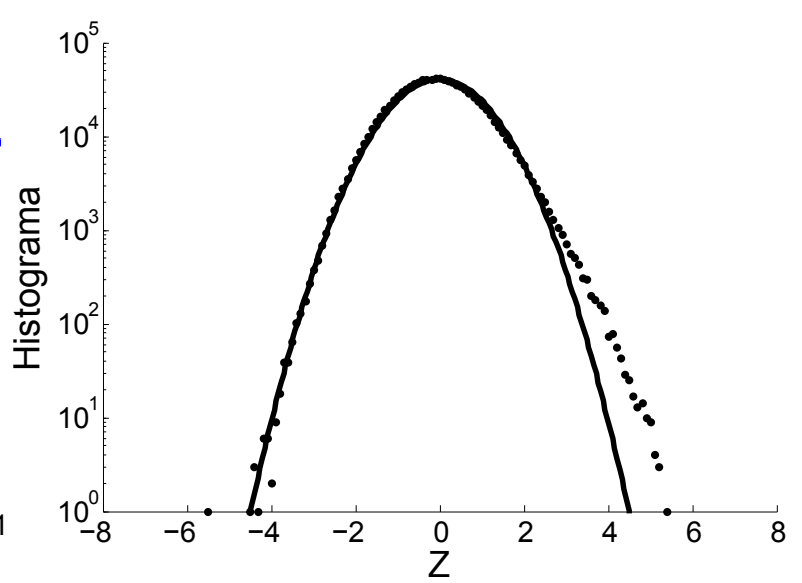

(b)

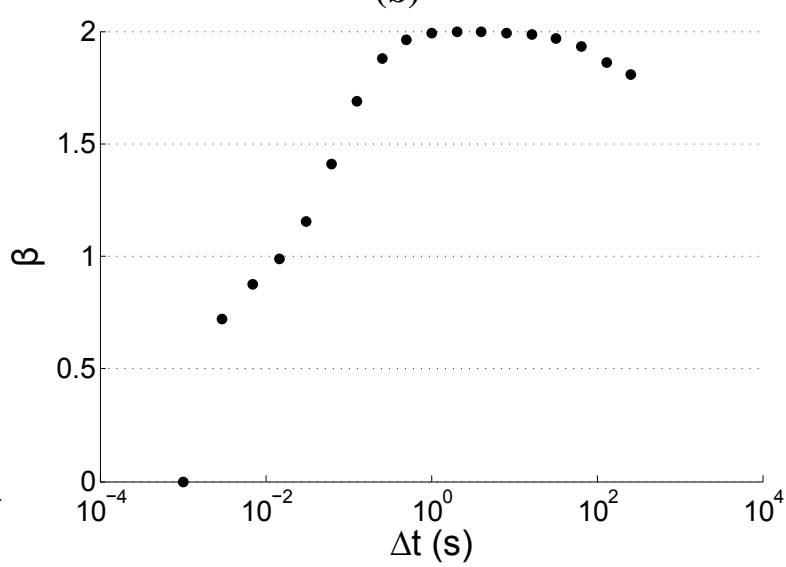

(d)

Figura 7.4-15. Gráficos obtidos da simulação com blocos deslizantes baseada nas Eqs. 7.56. a) Primeiro segundo das posições $y_{0}$ e $y_{1}$. b) Histograma dos $Z$ s. A linha contínua mostra o ajuste Gaussiano $y(x)=$ $a e^{-x^{2} / 2 \sigma^{2}}$, com parâmetros $a=40600$ e $\sigma=0.97$. c) MSD baseado em $y_{0}$. d) Inclinação do MSD.

Escolhendo então parâmetros no intuito de simular o observado experimentalmente, os gráficos mostrados na Fig. 7.4-15 foram obtidos. Os parâmetros usados foram: $v=5 \cdot 10^{-8} \mathrm{~m} / \mathrm{s}$, $F_{0}=1 \mathrm{nN}, \Delta t=10^{-3} \mathrm{~s}$ e $N=1000000$. Os outros parâmetros foram mantidos iguais aos usados na Seção 7.4.

Os comportamentos observados na Fig. 7.4-15 são bastante similares aos encontrados experimentalmente. Por exemplo, o MSD pode ser comparado com a Fig. 1.5-8, de onde pode ver a similaridade. O MSD obtido na modelagem anterior, Seção 7.3.3, apresenta um platô que não é realístico, apenas uma aproximação. Já na modelagem dessa seção, o MSD começa com 


\section{Movimento Browniano e Modelagem da Dinâmica do Citoesqueleto}

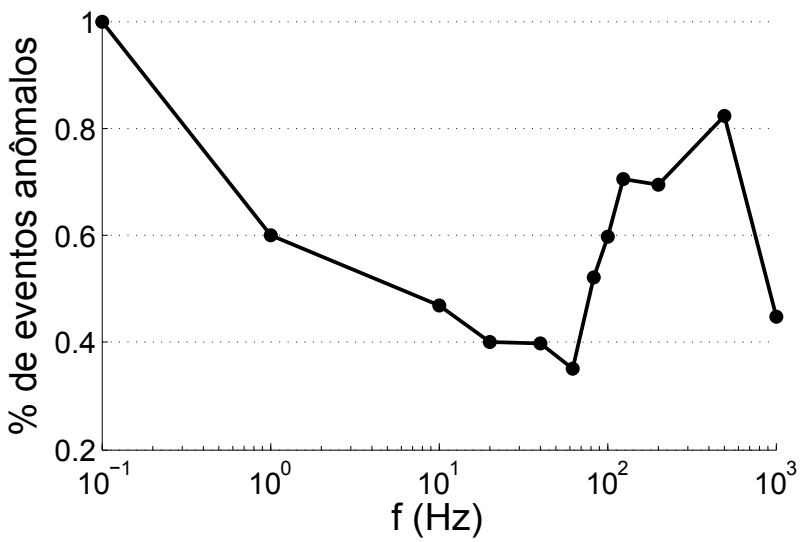

Figura 7.4-16. Porcentagem de eventos anômalos onde $Z \geq 3$ para diferentes frequências de aquisição.

um comportamento subdifusivo e muda para um comportamento superdifusivo como o esperado. Há também os saltos anômalos que agora estão presentes, diferentemente da modelagem anterior, ver Fig. 7.3-12.

Em relação a frequência de aquisição de dados, a partir da simulação pode-se inferir a quantidade de eventos anômalos em possíveis diferentes frequências de aquisição, como no Cap. 6. Assim, a partir da frequência da simulação de $1000 \mathrm{~Hz}$, a quantidade de eventos anômalos foram calculados para sub frequências de: $0.1,1,10,20,40,62.5,83.3,100,125,200$ e $500 \mathrm{~Hz}$. Foram contabilizados todos os eventos com $Z \geq 3$. Os valores encontrados estão mostrados na Fig. 7.4-16.

A Fig. 7.4-16 mostra a maior porcentagem de eventos anômalos em 0.1 Hz. Aumentando a frequência, a porcentagem diminui, mas aumenta novamente, chegando a um segundo pico em $500 \mathrm{~Hz}$. E posteriormente decai novamente. A menor porcentagem de eventos pode ser vista na frequência de $62.5 \mathrm{~Hz}$. O comportamento inicial da porcentagem de eventos anômalos é similar ao encontrado experimentalmente, ver Fig. 6.2-7.

O segundo pico na Fig. 7.4-16 pode ser explicado em termos do tempo necessário para a acomodação do modelo, visto que o limiar de força de atrito $F_{0}$ é constante. Com o $\Delta t$ da 


\section{Movimento Browniano e Modelagem da Dinâmica do Citoesqueleto}

simulação, no caso $10^{-3} \mathrm{~s}$, não é possível ver um salto inteiro, mas com um $\Delta t$ um pouco maior, no caso $\Delta t=2 \cdot 10^{-3} \mathrm{~s}$, já é possível observar a maior parte dos saltos completos.

Já o aumento encontrado nas frequências mais baixas está relacionado a um acúmulo de eventos observados no intervalo de tempo referente. Quanto menor a frequência, maior a quantidade de eventos naquele intervalo, anômalos ou não, o que proporcionaria um aumento na porcentagem.

A simulação foi feita com o bloco deslizante sendo puxado apenas para a direção positiva do eixo $x$. Mas a mesma pode ser feita variando a direção, obtendo histogramas simétricos, representando o que é visto experimentalmente. 


\section{Capítulo 8}

\section{Outros Desenvolvimentos}

\subsection{Cardiomiócitos}

Os cardiomiócitos são as células do músculo cardíaco. Eles são responsáveis pelo permanente fluxo sanguíneo no corpo, compondo os átrios e ventrículos, câmaras onde o sangue entra e é bombeado para fora do coração. Essas células também possuem a capacidade de encurtarem ou elongarem suas fibras, sendo bastante flexíveis, e fundamental para o batimento cardíaco, que ocorre mesmo em meio de cultura ${ }^{1}$. Os cardiomiócitos são estimulados eletricamente pelas células marcapasso. Esse estímulo é transmitido célula a célula permitindo o músculo cardíaco se comportar como uma única unidade coordenada [78]. Neste caso, a comunicação entre cardiomiócitos é complexa e estabelecida de maneira mecânica, elétrica e química [79]. Assim, em meio de cultura, a sincronia das mesmas somente acontece em um sistema confluente [80].

O cardiomiócito é um músculo estriado, com estreitas faixas escuras e claras, devido ao arranjo paralelo de actina e miosina, que se estendem a partir de uma extremidade à outra de cada

\footnotetext{
${ }^{1}$ Imagens de cardiomiócito batendo em cultura pode ser vista em: http://fig.if.usp.br/ labm2/ Pesquisa/cardiomiocito.html
} 


\section{Outros Desenvolvimentos}

miócitos, sendo responsável pela batimento cardíaco. As miofibrilas consistem de proteínas contráteis envolvidas na geração de força e na manutenção da estrutura física do CSK muscular. Também, através dessa estrutura ocorre a interação mecânica com outros cardiomiócitos e com a matriz extracelular [81].

É indiscutível o fato do coração ser um órgão de suma importância para o bom funcionamento e saúde do corpo. Desta maneira, exitem pesquisas que buscam à regeneração do coração por implante de células saudáveis, ou geneticamente manipuladas. Porém, esse tipo de pesquisa passa necessariamente por estudos in-vitro. O Instituto do Coração/Hospital das Clínicas da Faculdade de Medicina da USP (InCor/HC-FMUSP) pesquisa assuntos relacionados visando a regeneração do coração. Aqui realiza-se estudos usando técnicas de rastreamento de partículas, similar ao que foi feito no Cap. 3, e de microscopia de força de tração (TFM) para caracterizar essas células fisicamente e discutir acerca de suas propriedades mecânicas.

Aqui o interesse é a demonstração dos princípios metodológicos, enfatizando a comparação das medidas por rastreamento de partículas com TFM, além de provar a viabilidade para estudos avançados. Para melhor caracterizar as propriedades dos cardiomiócitos, serão realizados experimentos usando um fármaco como desafio. No caso será utilizado isoproterenol, que é uma droga que atua tanto na frequência quanto na força da pulsação do cardiomiócito. Isoproterenol tem efeito dose dependente, aumentando a frequência de batimento, em comparação com a frequência da linha de base [82].

\subsubsection{Métodos}

As células de cardiomiócitos foram obtidas por uma parceria com o Laboratório de Genética e Cardiologia Molecular do InCor formalizada por meio de um projeto temático e um regular da FAPESP, respectivamente 2013/17368-0 e 2014/22102-2. As células são retiradas de rato 


\section{Outros Desenvolvimentos}

neonato tipo selvagem (WT, do inglês Wild Type) e transportadas para o $\mathrm{LabM}^{2}$ congeladas em nitrogênio líquido, onde os procedimentos experimentais foram realizados.

Para o rastreamento de partículas, as microesferas foram aderidas nas células como descrito no Cap. 3. Mas as imagens foram obtidas com o uso da câmera da Andor e com o auxílio de um microcontrolador ATmega328 (Processador da família Risc, da Atmel Corporation), como no Cap. 6. Desta maneira, poder-se-á obter imagens com altas frequências, o que possibilitará um maior detalhamento nas informações que serão obtidas.

Para se quantificar as forças contráteis, será utilizada a técnica conhecida como microscopia de força de tração (TFM) $[30,83,84]$. De onde se consegue medir diretamente as forças que as células geram no substrato $[85,86]$.

Nesta técnica, as células são aderidas a um substrato flexível com marcadores, beads fluorescentes, ver Fig. 8.1-1. Os substratos flexíveis são preparados com poliacrilamida, um gel versátil cuja rigidez pode ser controlada a partir da proporção entre monômeros de acrilamida e o crosslinker Bis na solução a polimerizar. Após ativar quimicamente a placa de Petri com fundo de vidro onde o gel será formado, um volume determinado de solução a polimerizar é depositado sobre ele e uma lamínula é colocada em cima para dar formar o gel por capilaridade. Após 30 minutos, o gel estará polimerizado, bastando retirar a lamínula usada para dar forma. Após retirar a lamínula, a superfície é ativada com o crosslinker Sulfo-SANPAH. Assim, é possível marcar o gel com beads fluorescentes e também depositar a matriz extracelular desejada, no caso, colágeno. Após as células serem depositadas, espera-se em torno de 24 h e o experimento pode ser iniciado. Primeiramente tira-se uma imagem fluorescente com a célula e posteriormente faz-se um tratamento com tripsina, para retirar as células observadas, e por final, tira-se outra foto sem as células em questão. As trações são então obtidas medindo-se os campos de deslocamentos gerados pelas células nos marcadores do substrato. Para a análise dos dados do TFM, será utilizado um software desenvolvido pelo pesquisador Dr. Chan Y. 

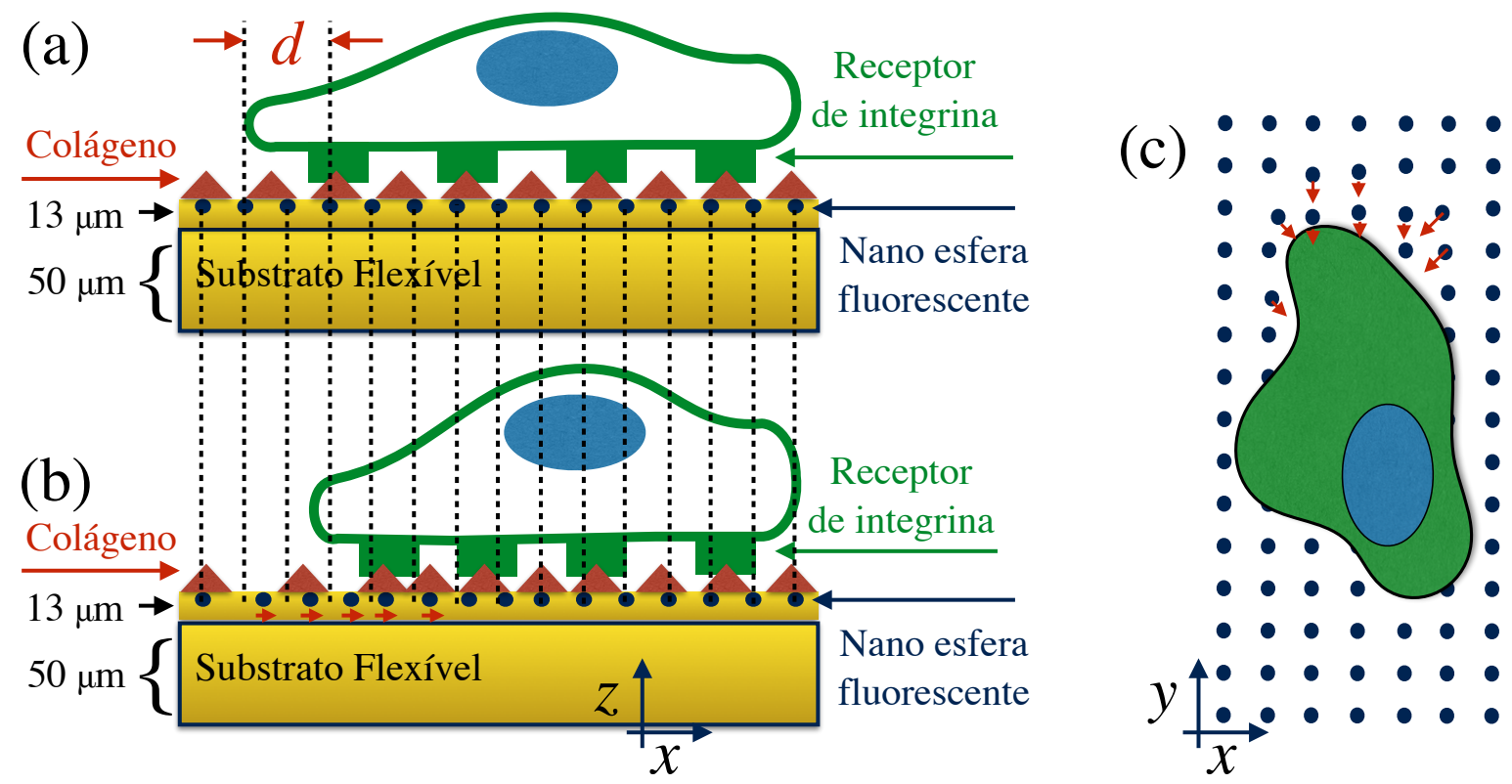

Figura 8.1-1. Esquema da técnica de TFM. (a) primeiro as células são depositadas no substrato marcado com beads fluorescentes. (b) Depois da adesão, a tração produzida pelas células puxam os beads resultando numa alteração das suas posições iniciais. (c) Vista de cima do campo de deslocamento.

Park [87], que também é parceiro nesse projeto.

A partir das trações obtidas, pode-se calcular o momento contrátil total, para maiores detalhes ver [84]. Esse cálculo é importante para a comparação entre os diferentes experimentos.

Espera-se com essas duas técnicas poder quantificar a frequência de batimento e as trações, com e sem a droga, e conseguir caracterizar as células mecanicamente.

\subsubsection{Resultados Preliminares e Discussão}

A observação da difusão é um experimento passivo, como visto nos capítulos anteriores, e nos mostra a dinâmica do citoesqueleto sem interferências externas. Mas usar essa técnica para cardiomiócitos é bem diferente. Como os cardiomiócitos contraem em cultura, o que se verá é um movimento oscilatório das microesferas referentes a essa contração. Com esse fato, pode-se 


\section{Outros Desenvolvimentos}

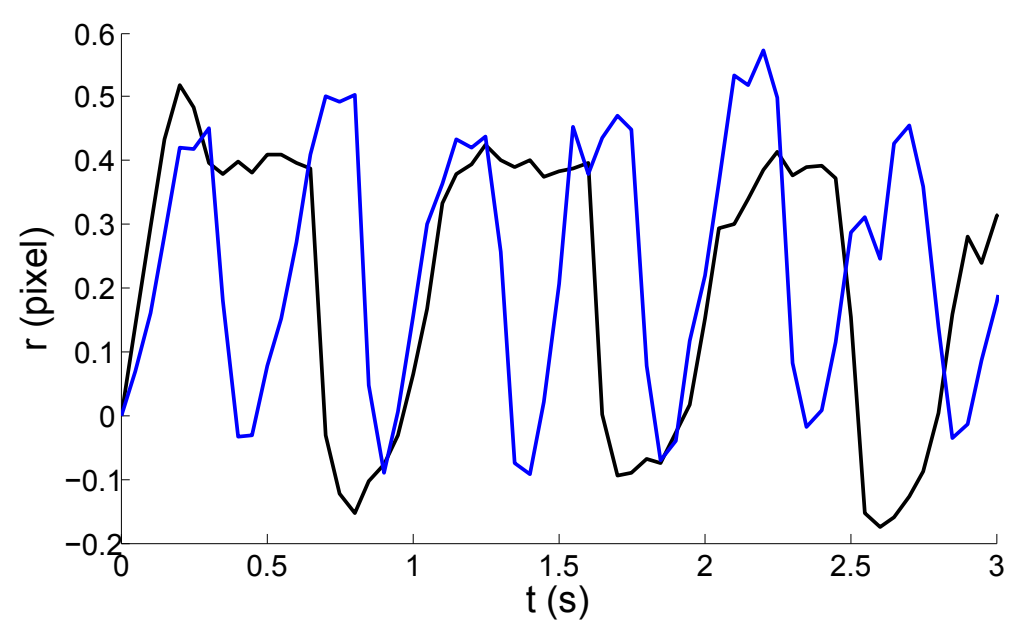

Figura 8.1-2. Posição $r$ em pixel de uma microesfera aderida em um cardiomiócito do tipo WT. A linha em preto representa a movimentação antes do fármaco e a linha em azul depois do fármaco.

obter diversas informações, como a frequência de batimento, amplitude e duração da contração. A Fig. 8.1-2 mostra um exemplo dessa dinâmica de uma microesfera em um cardiomiócito, antes e depois da aplicação de isoproterenol.

A partir das imagens dos deslocamentos das microesferas pode-se inferir a frequência de batimento, no caso $1.8 \mathrm{~Hz}$ antes da droga, e $2.1 \mathrm{~Hz}$ depois da droga.

A movimentação da microesfera está diretamente correlacionada com a contração da célula, e esta pode ser vista pelas trações que elas fazem no substrato a que estão aderidas. Assim, a partir da técnica de TFM, é possível observar essas trações, e como elas variam com o tempo. A Fig. 8.1-3 mostra um exemplo de imagens obtidas pela técnica de TFM para cardiomiócito do tipo WT. Um filme da sequência dessas imagens pode ser visto no site: http: / / fig. if . usp.br/ labm2/Pesquisa/cardiomiocito.html.

Para as análises foi calculado o momento contrátil total utilizando uma taxa de aquisição de 20 fps, de onde também pode-se obter a frequência de batimento. Para um fps de 20 a resolução temporal é de $1 / 20$ s, com uma incerteza na medida individual de um intervalo temporal entre pulsos de $1 / 10$ s. Para uma média de 3 amostras realizadas, foram encontrados os valores de 


\section{Outros Desenvolvimentos}
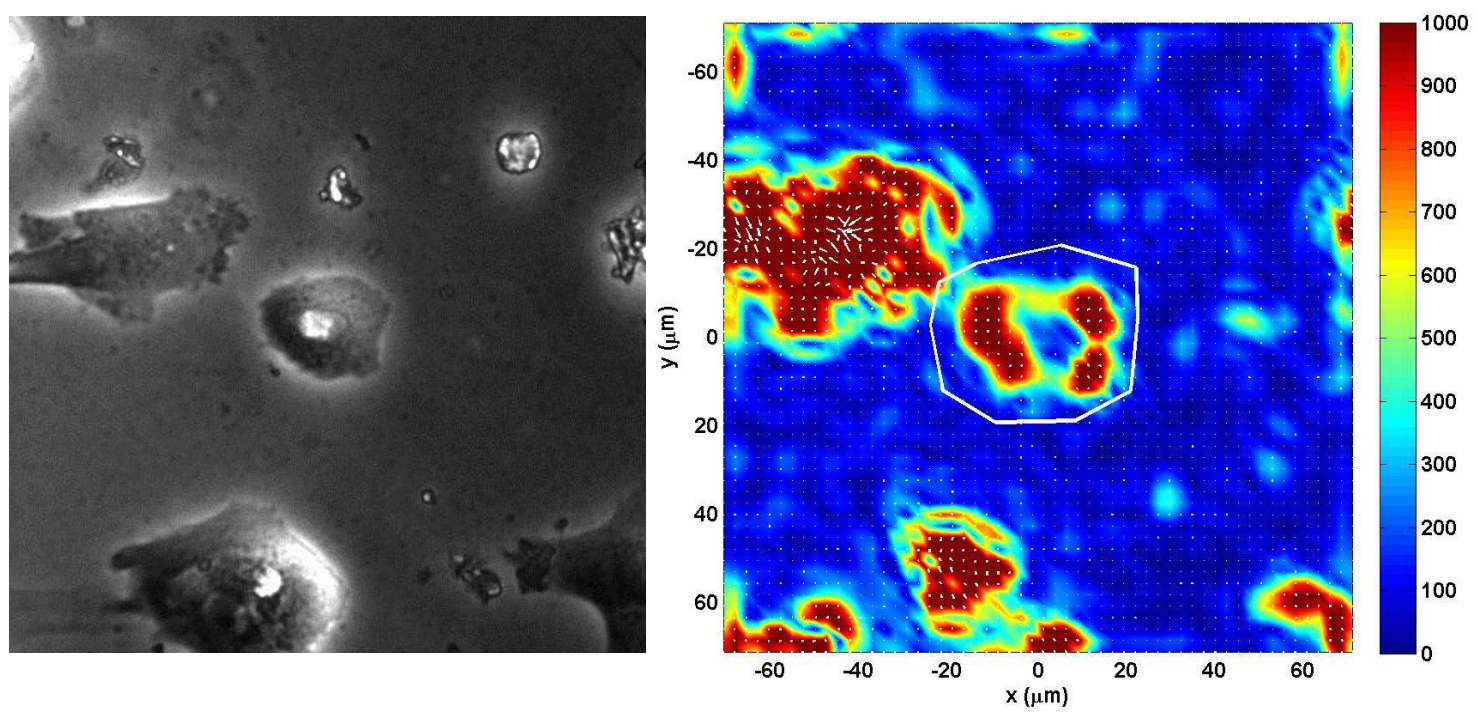

Figura 8.1-3. Imagem em contrate de fase do cardiomiócito do tipo WT e suas trações referentes. A célula considerada no cálculo está delineada em branco. As trações estão em Pascal.

\section{$1.49 \mathrm{~Hz}$ antes e $1.98 \mathrm{~Hz}$ depois.}

Apesar de não ter sido feita a análise dos dois métodos nas mesmas células, foi demostrado que o rastreamento de partículas na superfície dos cardiomiócitos também captura as características principais do batimento de cardiomiócitos. Comparativamente com o TFM, esse método é mais econômico e pode ser utilizado como substituto caso não exista a necessidade de uma grande precisão.

Com o uso do microcontrolador ATmega328, ver Cap.6, é possível obter resultados com alto nível de detalhamento. Um exemplo pode ser visto na Fig. 8.1-4 onde pode-se notar a grande quantidade da dados obtidos usando frequência de $100 \mathrm{fps}$. Nesse resultado, foi calculado a dinâmica do momento contrátil total, usando a rotina de análise do TFM, onde pode ser notada a estabilidade dos dados experimentais, fato que não era possível com baixa taxa de amostragem. Usando uma segunda rotina computacional, foram identificados os picos e vales da curva temporal dos momentos contráteis e marcado com asteriscos em vermelho e azul 


\section{Outros Desenvolvimentos}

respectivamente. Nesse experimento, na curva obtida antes do uso do fármaco Isoproterenol, foram identificados 125 picos em um total de 78 segundos de experimento. A frequência e a amplitude encontradas com seus respectivos desvios foram de (1.6 \pm 0.2$) \mathrm{Hz}$ e $(25.8 \pm 0.6) \mathrm{pNm}$. Para a curva encontrada depois do uso do fármaco, foram identificados 249 picos em um total de 79 segundos de experimento, praticamente dobrando a frequência do batimento. A frequência e amplitude com seus respectivos desvio foram de $(3.16 \pm 0.26) \mathrm{Hz}$ e $(25.43 \pm 1.15) \mathrm{pNm}$.

Também foram encontradas as densidades de probabilidades dos intervalos temporais obtidos entre os pulsos vistos na Fig. 8.1-4, mostradas na Fig. 8.1-5. A curva contínua representa a densidade de probabilidade antes do uso do fármaco, e a curva pontilhada, após o uso do fármaco. A distribuição do intervalo temporal entre picos também pode ser útil para caracterizar essas células, dando mais parâmetros para análises.

A técnica de TFM com alta frequência mostrou-se bastante robusta, aumentando a resolução temporal e a definição mais precisa dos picos. Para a análise da frequência média dos picos, o aumento da resolução é pouco significante, pois os erros individuais são diluídos no todo. Por outro lado, ganha-se bastante na resolução da densidade de probabilidade de um intervalo temporal, esse novo dado, funciona como um parâmetro de segunda ordem para a quantificação e caracterização das células em questão. Esses parâmetros são importantes quando diferenças sutis são procuradas. Outro ponto importante, é que uma maior definição temporal permite a caracterização de eventos anômalos, abrindo um novo ramo de possibilidade de pesquisa.

\subsection{Compressão Celular}

Todos os estudos apresentados até o momento envolve a presença de microesferas para a detecção da movimentação e reorganização do CSK. Esse método pode permitir o entendimento 

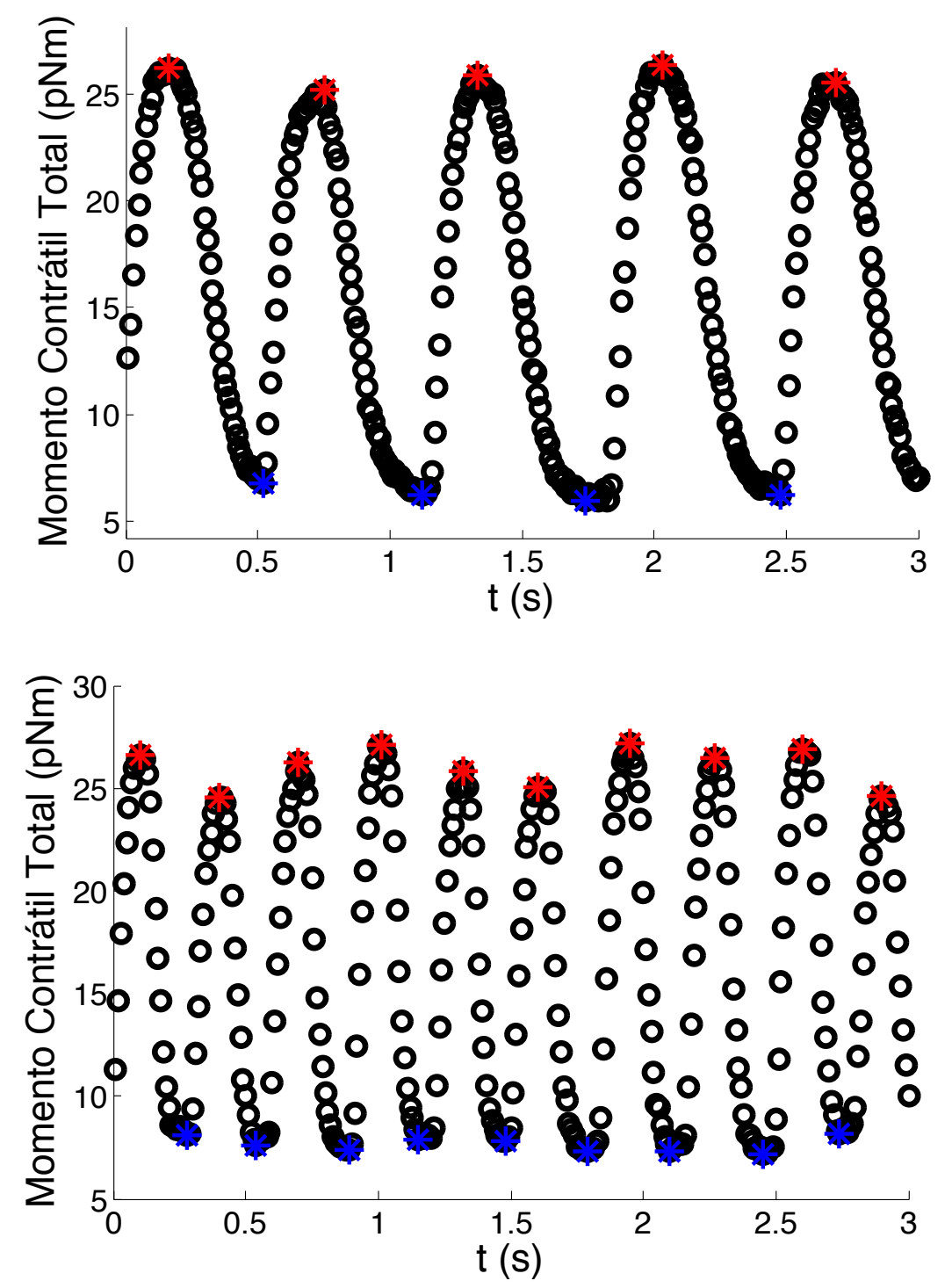

Figura 8.1-4. Momento contrátil total de cardiomiócito do tipo WT utilizando a técnica de TFM com alta frequência de aquisição, $100 \mathrm{fps}$. A curva do topo foi obtida antes do uso do fármaco Isoproterenol, enquanto de baixo foi obtida após. Os asteriscos em vermelho e azul são respectivamente os picos e vales encontrados na curva.

de comportamentos e de atividades celulares que por exemplo diferenciam células epiteliais e células de músculo liso. Essas atividades foram medidas dentro de unidades celulares individuais e tratadas como elementos independentes. Todavia, no corpo humano, as células estão conectadas umas as outras formando os tecidos, e suas ações e atividades são coletivas. Os 


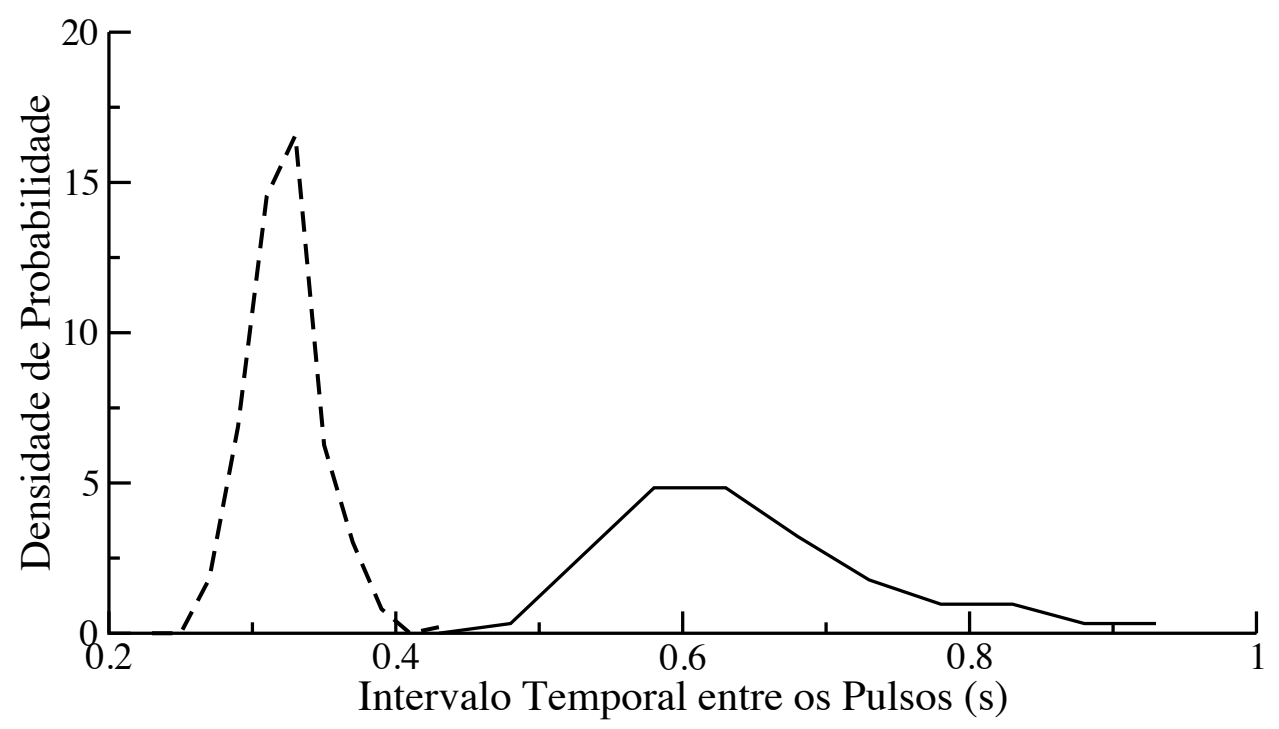

Figura 8.1-5. Densidades de probabilidades dos intervalos temporais entre os pulsos. A curva contínua foi feita para o caso antes do uso do fármaco, enquanto a linha pontilhada após o uso do fármaco.

filamentos de actina do CSK se ancoram nas adesões entre células vizinhas, transmitindo por exemplo mudanças de tensão. As atividades coletivas são de suma importância para manter os tecidos e suas funções. Nessa direção, no intuito de entender melhor os processos coletivos e como esses processos podem interferir nas atividades individuais das células, será iniciado uma nova metodologia para o estudo de células coletivamente, e posteriormente tentar vincular o que será encontrado com o observado individualmente. Para isso será utilizada a hipótese de cell jamming.

A hipótese de cell jamming foi discutida na Seção 1.6. Como dito anteriormente, muitas novas questões surgiram a partir daí. Dessa maneira, pode-se escolher um dos eixos do diagrama de fase, Fig. 1.6-13, para se explorar com mais cuidado. No caso, será olhado o eixo da densidade.

Pensando num epitélio, este precisa manter um número homeostático de células, combinando o número de células que se dividem com o número de células que morrem [32]. Em regiões populosas de um tecido as células são eliminadas para este fim, oque pode-se chamar 


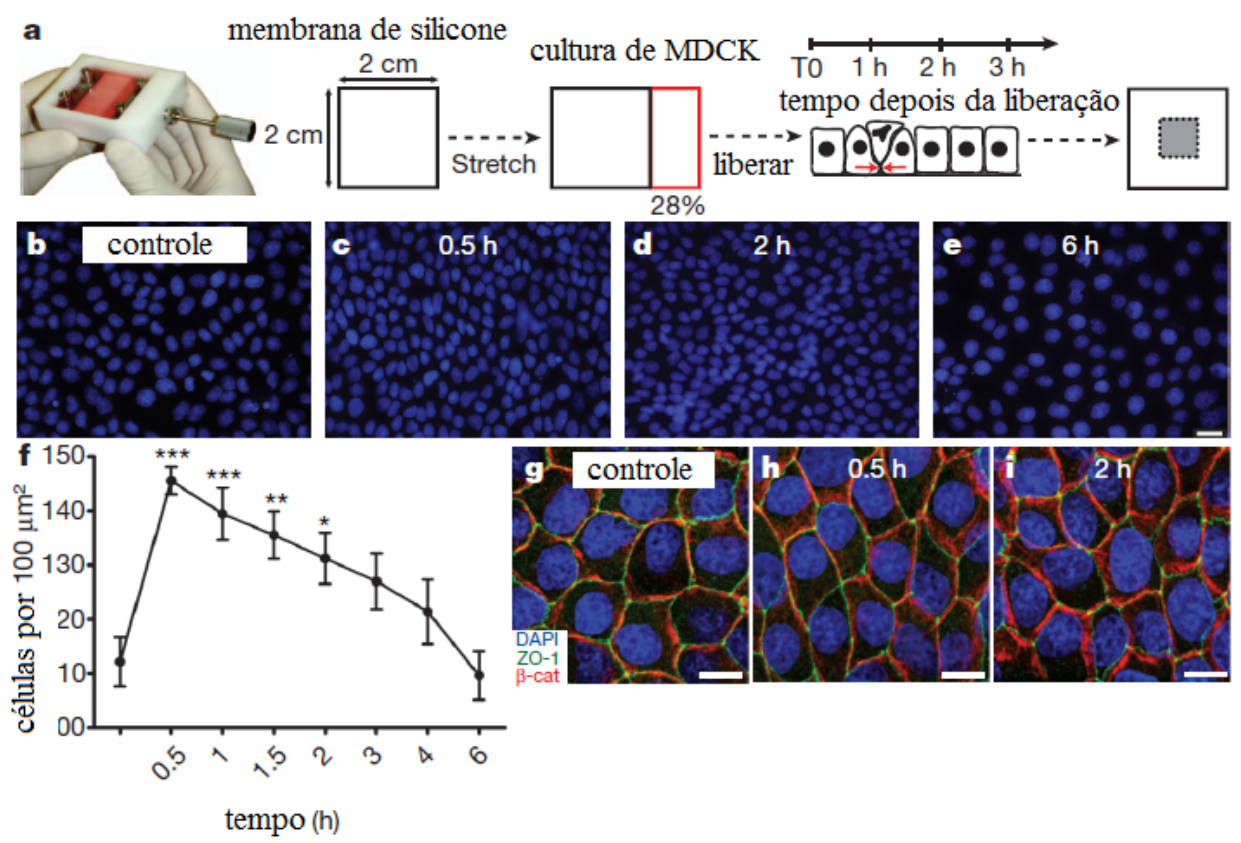

Figura 8.2-6. Caracterização da super-população experimental. a, Design experimental para crescimento monocamadas super-populosas numa membrana estirada. Somente células na área cinza (direita) foram analisadas para assegurar um campo de strain homogêneo. b-f, Imagens do núcleo de monocamadas controle 0.5-6 h depois da superpopulação (b-e) foram quantificadas em f. f, Número médio de núcleos por campo, as barras de erro representam o erro padrão da média. g-i, Monocamadas a 0.5 e $2 \mathrm{~h}$ depois de liberado o estiramento mostra que junções aderentes mantém a integridade depois da superpopulação, quando comparado com a controle. $\beta$-cat, $\beta$-catenin. Barra de escala, $10 \mu \mathrm{m}$. $* * * \mathrm{P}<0.0005, * * \mathrm{P}<0.005, * \mathrm{P}<0.05$. Adaptado de [32].

de extrusão celular.

Experimentalmente, pode-se observar a extrusão celular em monocamadas superpopulosas in vitro. Eisenhoffer et al. [32] usaram cultura de células do tipo MDCK em membranas flexíveis de silicone, que foram estiradas $28 \%$ e depois liberadas, Fig. 8.2-6. Depois de $30 \mathrm{~min}$ da liberação, o número de células por $100 \mu \mathrm{m}^{2}$ aumentou 1.3 vezes. ZO-1 e $\beta$-catenin confirmam que as junções estavam intactas. Após em torno de $6 \mathrm{~h}$, o número de células por campo volta a valores parecidos com os iniciais, o que indicaria que o epitélio de células de MDCK elimina células para manter um número homeostático.

As células extraídas da monocamada durante uma superpopulação foram identificadas como 


\section{Outros Desenvolvimentos}

sendo células vivas [32]. Estas são eliminadas por diferentes processos que células mortas, ou apoptóticas. A mecânica das células e suas forças envolvidas estariam diretamente envolvidas com esse tipo de extrusão celular?

Uma monocamada de células cultivadas in vitro não é homogênea. Ou seja, haverá regiões onde as células estariam mais jammed, e outras menos jammed. Ou ainda, a monocamada não necessariamente alcançou o estado de jamming, havendo clusters com diferentes padrões de velocidades. Pensando nisso, qual seria a relação entre o estado jamming da monocamada e a extrusão celular? Será que a extrusão ocorre em regiões mais ou menos jammed? Será que pode-se medir o unjamming ou o rejamming depois da extrusão? Essas questões estimularam o estudo da compressão celular e sua relação com a hipótese jamming.

\subsubsection{Métodos}

\section{Aparato para compressão celular}

Primeiramente para o experimento de compressão celular foi necessário o desenvolvimento de um aparato para esse fim. Esse aparato foi baseado na Ref. [88], e construído na oficina da universidade (MIT, Boston) durante o estágio sanduíche da aluna, ver Apêndice I, e posteriormente um réplica foi feita na oficina mecânica do Instituto de Física da USP. O aparato foi pensado para ser usado com flex membrane, uma membrana de silicone flexível que pode ou não já ser tratada com colágeno. A Fig. 8.2-7 mostra uma imagem do aparato, chamado de aparato para stretch equibiaxial.

Este equipamento contem 5 peças, que são, Fig. 8.2-7A:

1. cilindro de Delrin (\#1) que é a base do equipamento. Esta peça tem um anel onde é colocada a membrana de silicone. 


\section{Outros Desenvolvimentos}

A

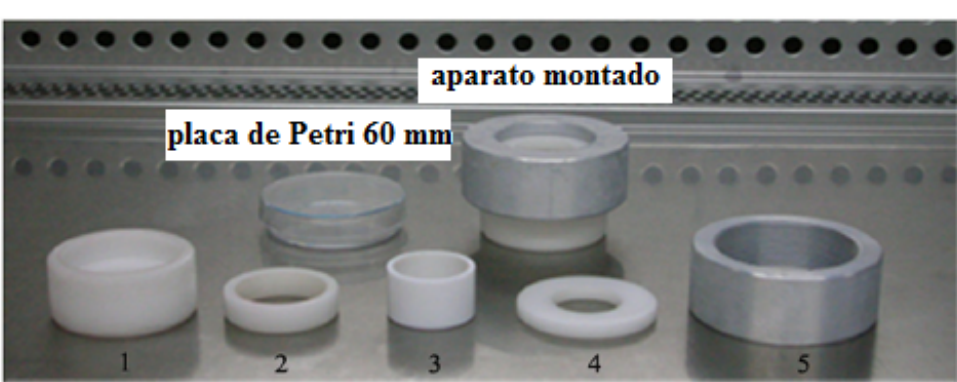

B

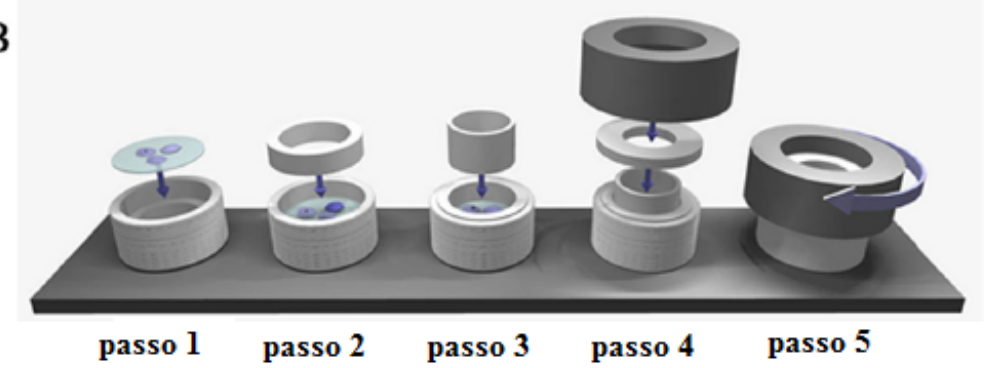

$\mathrm{C}$
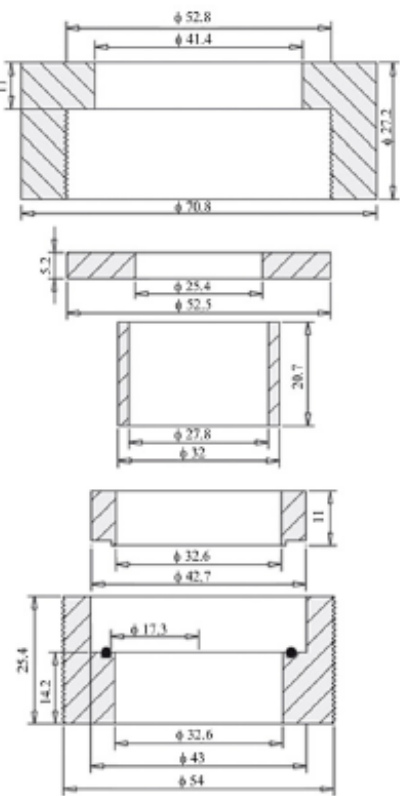

Figura 8.2-7. Aparato para stretch equibiaxial. (A) Aparato montado, e seus componentes individuais (1-5): 1) cilindro feito de Delrin com um anel interno que é onde irá se apoiar a membrana; 2) Anel feito de Delrin com um anel em O que fixa a membrana ao apoiador interno; 3) indentador feito de Teflon; 4) flange feito de Delrin que empurra para baixo a peça número 3; 5) tampa de Alumínio com rosca que empurra para baixo a peça número 4. (B) Diagrama mostrando o procedimento de montagem do aparato; passo 1 indica o posicionamento da membrana. (C) Cross-section do aparato completo. Para cada peça, as dimensões estão descritas em mm. Figura modificada de [88]

2. anel feito de Delrin (\#2) com um anel em O que se ajusta ao segurador interno da membrana dentro do \#1.

3. indentador feito de Teflon (\#3) que se encaixa na peça \#2.

4. flange feito de Delrin (\#4) que empurra para baixo o indentador (peça \#3)

5. tampa com rosca de alumínio (\#5) que quando fechada, empurra o indentador (\#3) para baixo, o qual estira a membrana de silicone.

O processo de montagem é descrito na Fig. 8.2-7B, e as especificações detalhadas na Fig. 8.27C. Em adição, outra informação importante seria a penetração da membrana por volta da tampa, que é $1.25 \mathrm{~mm} /$ volta. 
Os materiais usados são resistentes a altas temperaturas não perdendo suas propriedades físicas, e também podem ser esterilizados e autoclavados [88].

\section{Modelo teórico}

Quaglino et al. [88] desenvolveu um modelo teórico que descreve quanto a membrana é estirada por volta da tampa do aparato (peça \#5), Fig. 8.2-8. A área definida pelo anel em O foi considerada como sendo a superfície esticável, e está mostrada como o círculo de raio $a$. A área definida pelo indentador está mostrada como o círculo de raio $b$. Quando o flange é empurrado para baixo a uma distância $h$, a membrana adota uma formato de chapéu invertido, com raio $a$ em cima, e $b$ em baixo. Este formato foi teoreticamente redefinido como um novo círculo de raio $c$, cuja área pode ser calculada pela Equação (1). Assim, o incremento radial relativo da membrana $(c / a)$ pode ser calculado pela Equação (2). Desta maneira, tem-se quanto a membrana se estira teoreticamente, e pode ser comparado o funcionamento do aparato com essa curva teórica.

Como a idéia é comprimir a monocamada celular, através desse modelo também é possível calcular a compressão. Considerando agora que a situação inicial é a membrana totalmente estirada, no caso será considerado um total de 7 voltas, pode-se calcular quanto a membrana será comprimida a cada volta até chegar ao ponto zero onde não há estiramento. Assim, chamando o $c$ com 7 voltas de $c_{7}$, pode ser calculado a compressão radial da membrana $c / c_{7}$ fazendo $\sqrt{2 b h+a^{2}}$. Assim a porcentagem de compressão será $\left(c / c_{7}-1\right) \times 100 \%$.

\section{Calibração do aparato com a membrana}

Para a calibração do aparato, foi utilizada uma membrana para testes. É possível observar imperfeições na membrana, que servirão de referência para o cálculo de quanto a membrana está se estirando no aparato. 


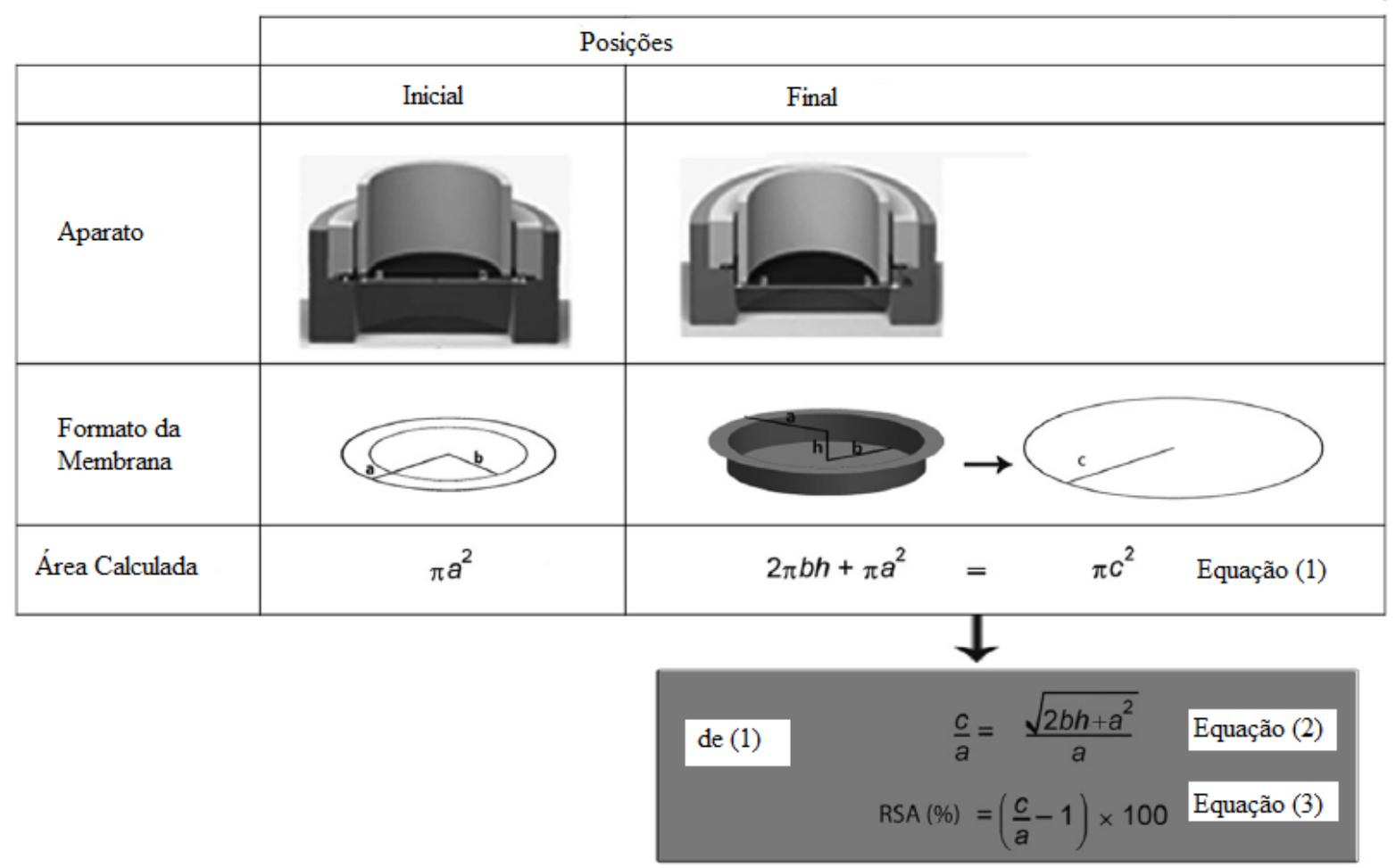

Figura 8.2-8. Modelo teórico para predizer a magnitude do strain da membrana. Posições inicial e final do aparato ( $1^{a}$ linha) e membrana ( $2^{a}$ linha). Equações que descrevem a área da membrana em cada posição ( $3^{a}$ linha). a: raio da área circular esticável; b: raio do círculo interno onde células podem ser visualizadas; h: distância feita pelo flange (peça \#4 da Fig. 8.2-7); c: raio de um círculo hipotético correspondente à área da membrana estirada na posição final (Equação (1)). O incremento relativo de $c / a$ pode ser calculado pela Equação (2). Equação (3) indica a porcentagem do strain radial aplicado (RSA) a membrana. Figura modificada de [88].

Primeiramente monta-se a aparato com uma membrana. Após a montagem, tira-se imagens da membrana na posição zero (sem estirar), e em cada volta. O aparato pode estirar a membrana em até 7 voltas, e as imagens foram tiradas na ida e na volta para cada volta da tampa.

Foram testadas três situações: temperatura ambiente com a membrana seca; temperatura ambiente com água deionizada; e overnight na incubadora. Para esse último teste foram tiradas as seguintes imagens: 1) posição zero, 2) depois de dadas as 7 voltas, 3) 7 voltas mais PBS, 4) foi deixado o aparato overnight na incubadora e tirada uma imagem, 5) imagens da volta.

Todas as curvas obtidas foram comparadas com a curva teórica. Para o cálculo do strain, 


\section{Outros Desenvolvimentos}

foram escolhidos em torno de 15 pares de pontos por toda a membrana e calculados as suas distâncias. Esses pontos são irregularidades da própria membrana visíveis em todo o processo. Todas as imagens tiradas foram comparadas com a imagem inicial, ponto zero, onde não há strain.

\section{Cultura celular}

Foram utilizadas dois tipos de células nesse experimento, uma epitelial e outra de músculo liso:

1. células epiteliais do tipo MDCK (tipo II), Madin-Darby Canine Kidney. As células foram cultivadas em frascos de plástico e incubadas a $37^{\circ} \mathrm{C}$ com $5 \%$ de $\mathrm{CO}_{2}$. O meio utilizado foi DMEM (Dulbecco's modified Eagle's medium) suplementados com 10\% de soro fetal bovino (FBS).

2. células de músculo liso do tipo RASM, Rabbit Aortic Smooth Muscle. As células foram cultivadas em frascos de plástico e incubadas a $37^{\circ} \mathrm{C}$ com $5 \%$ de $\mathrm{CO}_{2}$. O meio utilizado foi DMEM (Dulbecco's modified Eagle's medium) suplementados com 10\% de soro fetal bovino (FBS).

\section{Limpeza do aparato para o experimento}

Para a limpeza do aparato, segue-se o seguinte protocolo:

1. Preparar com água de torneira $1 \%$ de solução com ES-MPBIO (solução de limpeza) e mergulhar as peças do aparato overnight.

2. Retirar a solução e escovar com uma escova macia.

3. Enxaguar várias vezes com água de torneira. 


\section{Outros Desenvolvimentos}

4. Enxaguar com álcool.

5. Enxaguar com água deionizada.

6. Deixar secar.

7. Autoclavar.

\section{Procedimento pré-experimental}

Para a preparação dos experimentos, primeiramente separa-se duas membranas, uma para a montagem do aparato e outra para controle. Após montado o aparato, estira-se a membrana em torno de 6 a 7 voltas. As membranas devem ser lavadas com PBS. Coloca-se as células e deixa no incubador por 48 horas. Após atingida a confluência, pode-se iniciar os experimentos. Para MDCK coloca-se em torno de 800000 células e 400000 para RASM.

\section{Procedimento Experimental}

Para o procedimento experimental será usado um microscópio invertido (Leica) conectado a uma câmera. O microscópio é envolto por uma câmara de controle de temperatura, onde também faz-se o controle de gás. Serão obtidas imagens em contraste de fase, com magnificação de $10 \times$. A Fig. 8.2-9 mostra uma foto da montagem experimental no Laboratory for Molecular and Integrative Cellular Dynamics - Havard School of Public Health [34]. No LabM ${ }^{2}$ os experimentos serão realizados com a mesma montagem experimental descrita no Cap. 6, ver Fig. 6.1-1.

Primeiramente deve-se ligar o aquecedor do microscópio e esperar estabilizar, em torno de 40 min, e ligar o gás. Deve-se trocar o meio de cultura da amostra e esperar em torno de $1 \mathrm{~h}$ para iniciar o experimento.

Para o experimento, serão obtidas imagens por meia a uma hora para controle. Após essa fil- 


\section{Outros Desenvolvimentos}

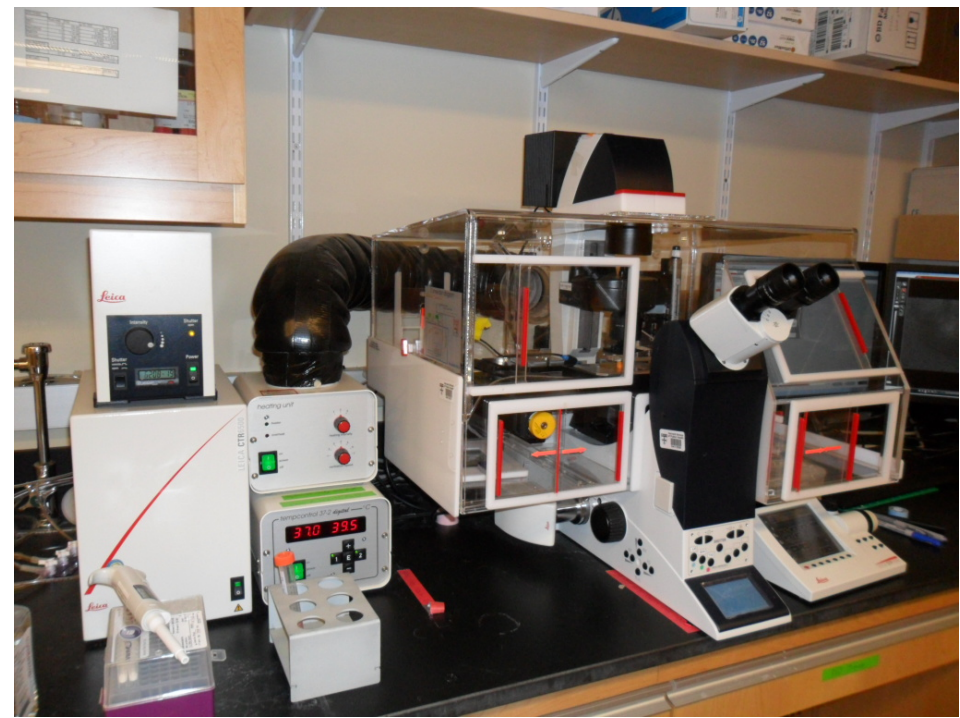

Figura 8.2-9. Montagem experimental do Laboratory for Molecular and Integrative Cellular Dynamics Harvard School of Public Health [34].

magem, solta-se o estiramento e filma-se novamente. Também serão realizados procedimentos de rastreamento de microesferas, como descrito no Cap. 3.

\section{Análise das Imagens}

As imagens serão analisadas usando o software livre ImageJ [66]. Esse software é amplamente usado para análise de imagens e experimentos biológicos e conta com diversos pluggins com diversas aplicações.

\subsubsection{Resultados Preliminares e Discussão}

\subsubsection{Modelo Teórico}

Para a construção da curva teórica foram utilizados valores diretamente das medidas do aparato: $a=16.3 \mathrm{~mm}, b=13.9 \mathrm{~mm}$ e $h=1.25 \mathrm{~mm}$ por volta. Desta maneira, encontra-se o gráfico mostrado na Fig. 8.2-10(a) através das equações mostradas anteriormente, ver Seção 8.2.1. Este 


\section{Outros Desenvolvimentos}

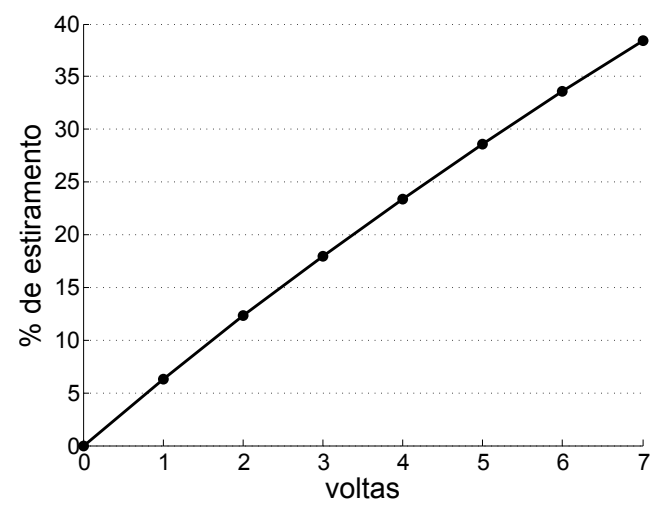

(a)

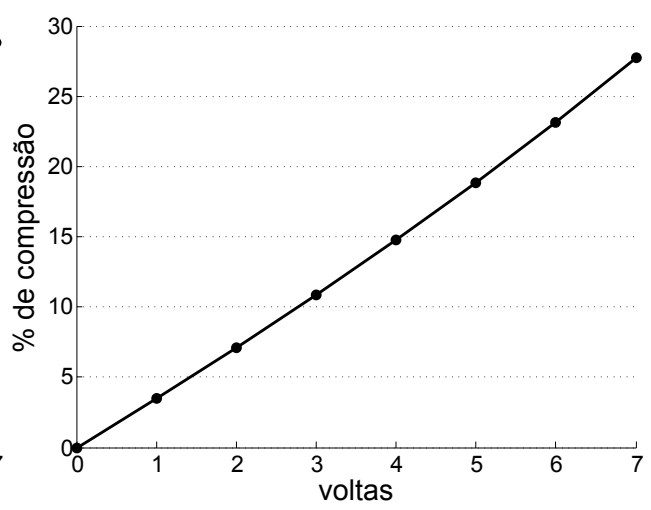

(b)

Figura 8.2-10. (a) curva teórica obtida para o estiramento, Fig. 8.2-8. (b) curva teórica obtida para compressão.

gráfico mostra qual a porcentagem de estiramento radial da membrana. A Fig. 8.2-10(b) mostra a curva para a compressão.

\subsubsection{Calibração do Aparato com a Membrana}

Foram realizadas calibrações do aparato com a membrana e comparadas com a curva teórica para estiramento obtida. A Fig. 8.2-11(a) mostra os resultados obtidos com temperatura ambiente e com a membrana seca. A Fig. 8.2-11(b) mostra os resultados obtidos com temperatura ambiente mas com a membrana molhada. E a Fig. 8.2-11(c) mostra os resultados obtidos depois de passar a noite com PBS no incubador.

Olhando os gráficos, Figs. 8.2-11, pode-se observar que para a curva de ida, o aparato funciona bem. Já para a curva de retorno, tem-se uma discrepância em relação a curva teórica. Mas, como a idéia é soltar o estiramento até a volta 1, essa discrepância não irá atrapalhar o curso dos experimentos.

A Fig. 8.2-11 abaixo foi realizada com a intenção de checar se após colocar o aparato no incubador, o estiramento sofreria alguma alteração, devido ao atrito entre a parede do aparato e a membrana. Mas após a realização desse teste, nota-se que não teve nenhuma alteração. Dessa 


\section{Outros Desenvolvimentos}

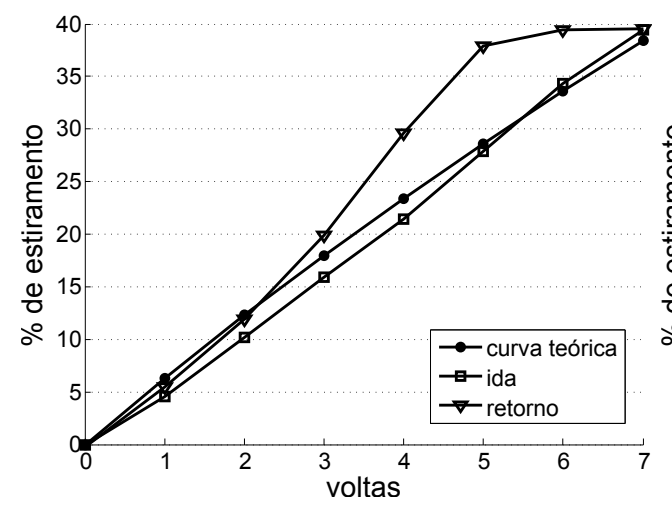

(a)

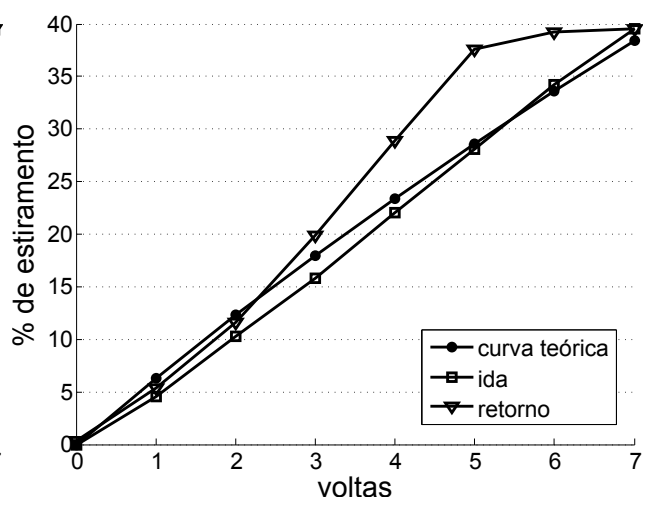

(b)

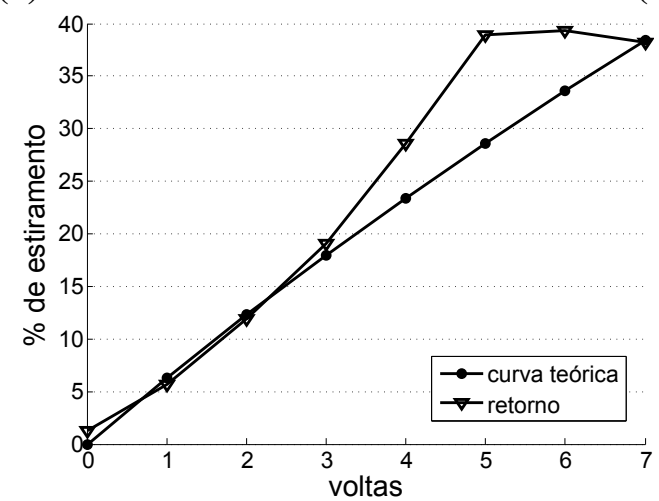

(c)

Figura 8.2-11. Curvas de calibração do aparato com a membrana. (a) curva obtida para temperatura ambiente e com a membrana seca. (b) curva obtida para temperatura ambiente e com a membrana molhada. (c) curva obtida depois de passar a noite com PBS no incubador.

maneira, o estiramento escolhido, terá o mesmo valor após ser colocado no incubador.

\subsubsection{Experimentos com células}

Primeiramente foram feitos experimentos com células do tipo RASM. Estas foram cultivadas dentro do aparato com a membrana estirada em 4 voltas. Após 48 h, o aparato é transferido para o microscópio e o experimento pode ser iniciado. Primeiramente são aderidas as microesferas como descrito no Cap. 3. A amostra é filmada por $1 \mathrm{~h}$ para controle, e depois o estiramento é liberado. A amostra é filmada por mais $5 \mathrm{~h}$. A frequência de aquisição utilizada foi de uma imagem por minuto. Também foram feitas aquisições com frequência de $20 \mathrm{~Hz}$ de hora em hora 


\section{Outros Desenvolvimentos}

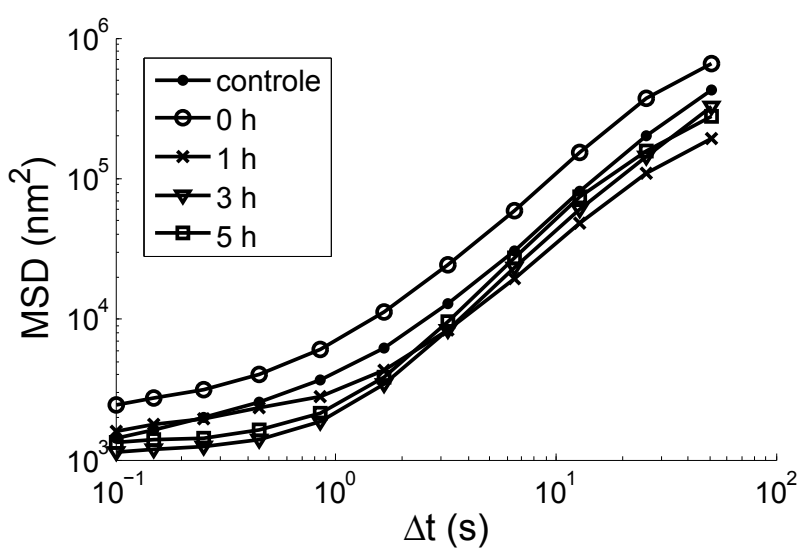

Figura 8.2-12. MSDs obtidos durante o experimento de compressão em momentos diferentes: logo no início, após a compressão de 4 voltas, uma horas depois, 3 horas depois e 5 horas depois. Foi utilizada frequência de $20 \mathrm{~Hz}$ e tempo de $100 \mathrm{~s}$.

por $100 \mathrm{~s}$ para o rastreamento das microesferas. Os gráficos dos MSDs obtidos está mostrado na Fig. 8.2-12.

Observando a Fig. 8.2-12, pode-se ver o comportamento das células durante os estágios, antes e depois da compressão. O MSD mantém a forma para todos os casos, mas seus valores mudam, ficando acima ou abaixo do controle. Pode-se ver que após a compressão há um aumento na atividade celular. Os deslocamentos são maiores que no controle. Nas horas posteriores, a atividade fica abaixo do controle, e em 5 horas ainda não volta para os mesmo valores iniciais.

As imagens das células também foram analisadas a fim de calcular a velocidade média durante o processo. Os valores encontrados estão mostrados na Fig. 8.2-13, de onde pode-se observar um aumento da velocidade após a compressão, e posteriormente uma queda na velocidade. A Fig. 8.2-14 mostra um exemplo do comportamento das células. Os vetores representam deslocamentos: a primeira imagem foi obtida do controle a partir de duas imagens com diferença de 4 min entre elas; já a segunda imagem foi obtida da mesma maneira, mas depois de $5 \mathrm{~h}$ da compressão (escala em pixel). Pode-se ver como no início havia uma maior atividade celular, enquanto que depois de $5 \mathrm{~h}$ a atividade é bem menor, como mostrado na Fig. 8.2-13. 


\section{Outros Desenvolvimentos}

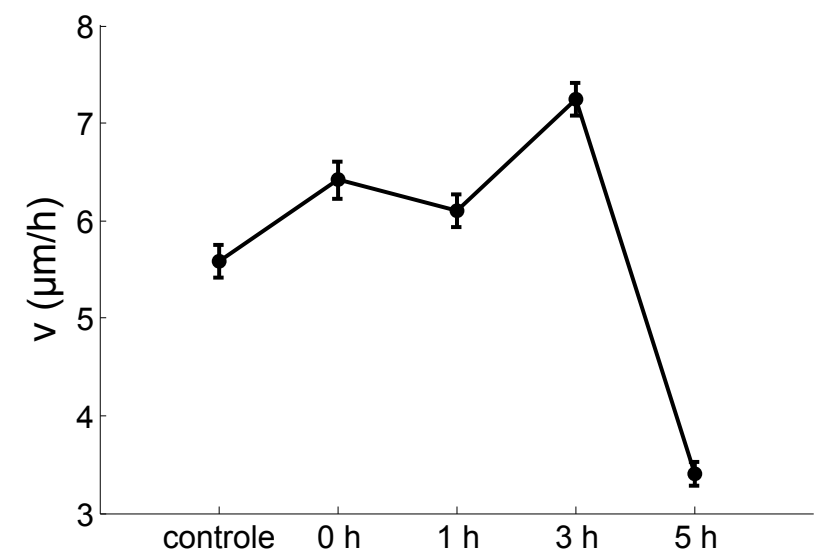

Figura 8.2-13. Velocidades calculadas em diversos estágios do processo de compressão para RASM.
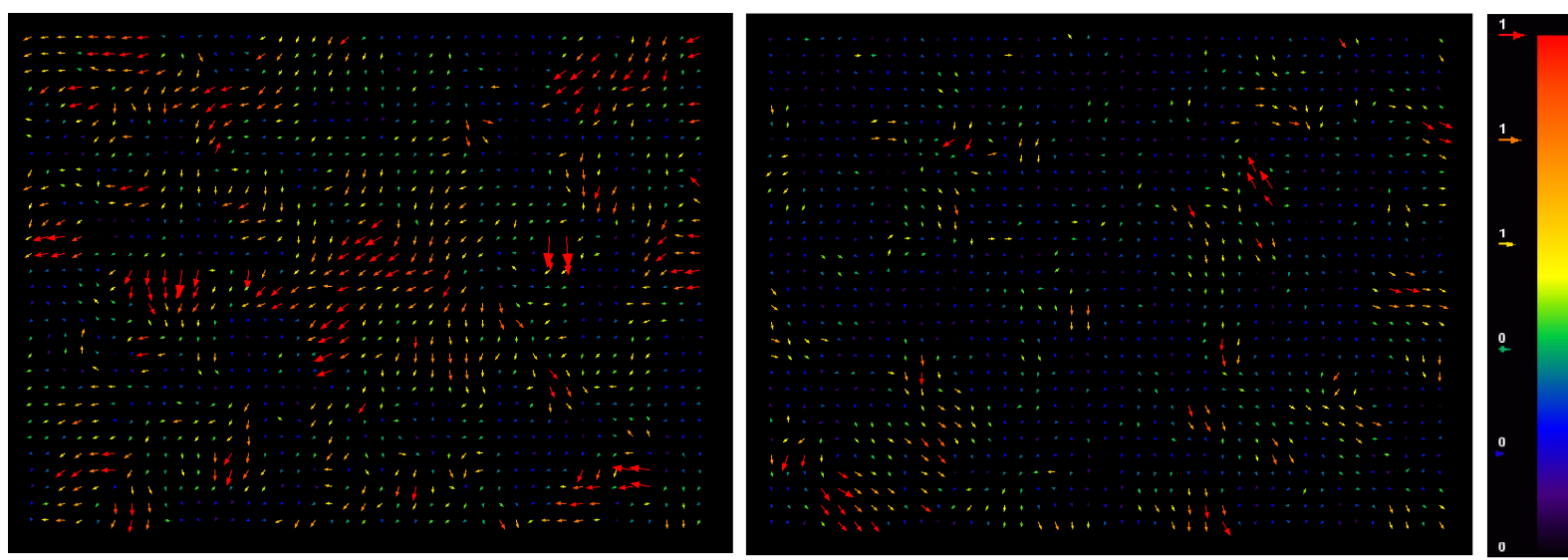

Figura 8.2-14. Vetores de deslocamento obtidos para o controle, imagem à esquerda, e após $5 \mathrm{~h}$ da compressão, imagem à direita. As imagens foram obtidas a partir de duas imagens com diferença de 4 min entre elas. Escala em pixel.

As células MDCK não se adaptaram bem dentro do aparato. Mas, quando cultivadas na membrana fora do aparato, e posteriormente colocadas dentro, elas sobreviveram. Desta maneira, foram feitos algum testes estirando essas células, ao invés de comprimir. As velocidades encontradas estão mostradas na Fig. 8.2-15. A velocidade aumenta levemente logo após o estiramento, e depois oscila com o passar do tempo.

A partir da Fig. 8.2-15 pode-se notar que as velocidades médias para o tipo de célula MDCK são menores do que para as RASM, Fig. 8.2-13. O que é esperado, pois as células de músculo liso são mais ativas que as epiteliais. Velocidades maiores estão relacionadas a maiores mo- 


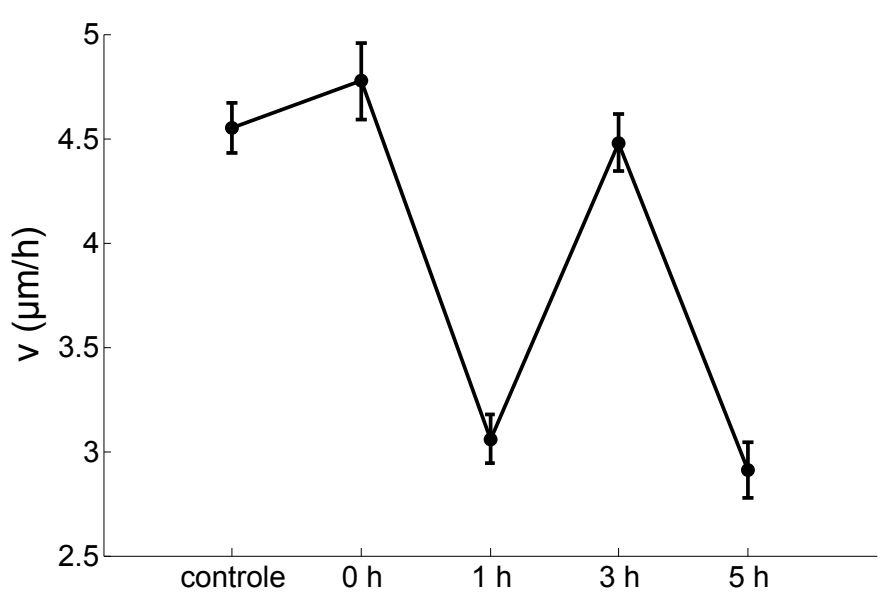

Figura 8.2-15. Velocidades calculadas em diversos estágios do processo de estiramento para MDCK.

vimentações celulares, o que implica em um maior uso de ATP, gerando maior atividade do citoesqueleto, principalmente do motores de actina e miosina. Este resultado corrobora o fato de se encontrar uma maior porcentagem de saltos anômalos em células do músculo liso do que epiteliais. 


\section{Capítulo 9}

\section{Conclusões}

A técnica de rastreamento de microesferas, juntamente com uma análise dos deslocamentos utilizando princípios de mecânica estatística, é capaz de identificar padrões de comportamento anômalo presente na dinâmica do citoesqueleto (CSK). O CSK é uma estrutura celular ativa, ou seja, ele faz uso de ATP para ativar motores celulares, que aumentam a tensão entre as fibras, gerando trabalho, e consequentemente a realização de suas funções mecânicas. Isso pode ser observado analisando a série temporal dos deslocamentos das microesferas. Olhando os histogramas dos Z's, há uma quebra do comportamento Gaussiano para em torno de $|Z|>3$ para as células de músculo liso, indicando um comportamento ativo. Essa quebra do comportamento Gaussiano ocorre, proporcionalmente, bem menos nas células epiteliais, o que reflete a baixa atividade mecânica celular, no que diz respeito a tensões internas. Já nos cardiomiócitos, essa dinâmica é bem mais ativa, refletindo a contração pulsátil dessas células. A conexão entre os processos anômalos e a atividade celular é reforçada quando depletamos ATP e as anomalias desaparecem.

Em relação ao comportamento de uma monocamada celular, este está de acordo com o 
que foi encontrado entre os tipos celulares diferentes, epitelial e músculo liso. As velocidades de movimentação é menor para as células epiteliais, mesmo depois das mesmas sofrerem um estiramento. Em relação à compressão, este provoca uma diminuição da atividade mecânica celular de acordo com a teoria jamming.

As anomalias encontradas nos deslocamentos também apresentam correlações temporais e espaciais, similarmente ao que é observado em abalos sísmicos. O CSK de células vivas exibe abruptas reconfigurações locais juntamente com transmissão de movimentos detectáveis a grandes distâncias numa maneira reminiscente a tremores na crosta terrestre. Desta maneira, essas flutuações locais fora do equilíbrio representam uma acomodação repentina dissipativa de uma falha estrutural e leva ao que foi chamado de cytoquake. Quantificar esse processo e modelar de forma similar a abalos sísmicos pode significar um grande avanço nessa área, uma vez que pouco se sabe tanto quanto sobre a forma que a célula acumula e como dissipa energia mecânica.

$\mathrm{Na}$ literatura, os experimentos de rastreamento de microesferas em células usam em torno de 12 frames per second (fps). Essa limitação no número de frames dificulta a quantificação do intervalo temporal dessas movimentações abruptas. Para melhorar essa resolução temporal, foram montados dois grupos experimentais com frequências de amostragem, fps, bem maiores. Mas o resultado obtido difere-se do esperado. Com o aumento dos fps, não ouve um aumento dos eventos anômalos, mas sim, uma diminuição exponencial dos mesmos. Todavia o estudo sistemático feito aqui indicou que a escala de tempo de atuação dessas forças se posiciona na ordem de segundos. Também conclui-se que esse tipo de estudo requer uma grande precisão no trigger da câmera, que dificilmente é obtida utilizando as ferramentas internas da câmera ou via software.

Foram utilizados três modelos matemáticos para capturar as características difusivas das microesferas anexadas no CSK. O primeiro modelo, foi o movimento Browniano comum, em que 


\section{Conclusões}

os deslocamentos são dados por uma distribuição Gaussiana tipo agitação térmica. Esse modelo é extremamente importante pois serve de base teórica para a distinção de comportamentos correlacionados para os não correlacionados, distribuição de eventos anômalos dentre outros. Apesar desse modelo ter sido utilizado em praticamente todos os capítulos da tese, ele, como era de se esperar, não reproduz o MSD das microesferas em células nem o comportamento anômalo dos deslocamentos. No segundo modelo utilizado, acrescentou-se ao modelo de agitação térmica, as fibras de estresse das células, representadas por molas elásticas de Hooke, dentro de um meio viscoso. Esse modelo mostra um comportamento difusivo para tempos pequenos, evoluindo para um platô, que representaria o comportamento subdifusivo observado experimentalmente. Acrescentando mais uma variável, com a inserção de uma movimentação global desse sistema, pode-se observar o comportamento superdifusivo esperado. Aqui, utilizou-se dados empíricos para se obter os parâmetros do modelo, e o mesmo consegue reproduzir várias propriedades experimentais medidas como a difusão e o MSD. Apesar de se obter uma dinâmica semelhante ao o que ocorre experimentalmente, não é observado nenhum comportamento anômalo. No terceiro modelo, é feita uma adaptação do modelo sísmico de Turcotte, que nesse caso é um re-arranjo do segundo modelo acrescentando atrito mas mantendo a agitação térmica. Esse modelo possui uma dinâmica parecida com a dinâmica do CSK conseguindo ainda reproduzir algumas das características anômalas encontradas experimentalmente. Novamente, essa análise numérica reforça as similaridades do que ocorre na crosta da terra e na superfície celular.

O rastreamento de partículas também pode ser usado para cardiomiócitos, células que se contraem em cultura. A partir dos deslocamentos das microesferas, pode-se inferir informações sobre amplitude de batimento e frequência de batimento. Com a técnica de microscopia de força de tração pode-se observar as forças no substrato durante o processo de batimento. Essa etapa definiu parâmetros e metodologias que já pode ser aplicada em pesquisas clínicas, principalmente as que almejam uma caracterização mecânica do componente mais importante 
Conclusões

do músculo cardíaco. 


\section{Apêndice A}

\section{Abordagem de Langevin Ao Movimento Browniano}

Langevin escreveu uma equação diferencial para o movimento de uma partícula em suspensão usando a força de Stokes e uma força aleatória $F$. Essa força aleatória, de caráter microscópio é atribuída ao bombardeio contínuo das partículas em suspensão pelas moléculas do fluido [14]. Para uma partícula esférica de massa $M$ e raio $a$, a equação de movimento é dada por:

$$
M \frac{d^{2} x}{d t^{2}}=-6 \pi \eta a \frac{d x}{d t}+F
$$

Multiplicando os dois lados por $x$ temos

$$
\frac{M}{2} \frac{d^{2}}{d t^{2}}\left(x^{2}\right)-M\left(\frac{d x}{d t}\right)^{2}=-3 \pi \eta a \frac{d}{d t}\left(x^{2}\right)+x F .
$$


Usando o teorema de equipartição da energia $\left\langle\frac{1}{2} M\left(\frac{d x}{d t}\right)^{2}\right\rangle=\frac{1}{2} \frac{R}{N_{A}} T$, e que $\langle x F\rangle=0$, devido ao caráter aleatório, ficamos com

$$
\frac{M}{2} \frac{d^{2}}{d t^{2}}\left\langle x^{2}\right\rangle-\frac{R}{N_{A}} T=-3 \pi \eta a \frac{d}{d t}\left\langle x^{2}\right\rangle
$$

de onde vem que

$$
\frac{d}{d t}\left\langle x^{2}\right\rangle=\frac{R T}{3 \pi \eta a N_{A}}+C \exp \left(-\frac{6 \pi \eta a}{M} t\right)
$$

onde $C$ é uma constante.

Para tempos suficientemente longos, o termo exponencial vai a zero,

$$
\frac{d}{d t}\left\langle x^{2}\right\rangle=\frac{R T}{3 \pi \eta a N_{A}}
$$

de onde encontramos o resultado de Einstein como na seção anterior

$$
\left\langle x^{2}\right\rangle-\left\langle x_{0}^{2}\right\rangle=\frac{R T}{3 \pi \eta a N_{A}} t
$$

A versão moderna da teoria de Langevin é descrita abaixo, onde a força $F$ é uma variável aleatória, de média nula e covariância associada a uma função $\delta$ de Dirac.

Considere uma partícula de massa $m$ imersa em um fluido. Esta partícula estará sujeita a um atrito viscoso, proporcional a sua velocidade, e forças de caráter aleatório devido ao impacto da partícula com as moléculas do meio [8,9,89]. Considerando o problema em uma dimensão, temos:

$$
m \frac{d v}{d t}=-\alpha v+F(t)
$$

onde $v$ é a velocidade da partícula, $\alpha$ é uma constante, o primeiro termo do lado direito é a força 


\section{Abordagem de Langevin Ao Movimento Browniano}

viscosa e $F(t)$ é a força aleatória, a qual tem as seguintes propriedades:

$$
\begin{array}{r}
\langle F(t)\rangle=0, \mathrm{e} \\
\left\langle F(t) F\left(t^{\prime}\right)\right\rangle=C \delta\left(t-t^{\prime}\right),
\end{array}
$$

pois considera-se que os impactos sejam independentes.

A equação escrita anteriormente, juntamente com as propriedades de $F(t)$, é conhecida como Equação de Langevin. Pode-se escrever:

$$
\frac{d v}{d t}=-\gamma v+\xi(t)
$$

onde $\gamma=\alpha / m$ e $\xi(t)=F(t) / m$. Assim:

$$
\begin{array}{r}
\langle\xi(t)\rangle=0 \mathrm{e} \\
\left\langle\xi(t) \xi\left(t^{\prime}\right)\right\rangle=A \delta\left(t-t^{\prime}\right),
\end{array}
$$

onde $A=C / m^{2}$.

Para resolver a equação (A.10) pode-se escrever que $v(t)=w(t) e^{-\gamma t}$, onde $w(t)$ deve ser determinada. Substituindo na equação de Langevin, obtem-se:

$$
\begin{array}{r}
\frac{d w(t)}{d t}=\xi(t) e^{\gamma t} \\
w(t)=w_{0}+\int_{0}^{t} e^{\gamma t^{\prime}} \xi\left(t^{\prime}\right) d t^{\prime}
\end{array}
$$

Então

$$
v(t)=v_{0} e^{-\gamma t}+e^{-\gamma t} \int_{0}^{t} e^{\gamma t^{\prime}} \xi\left(t^{\prime}\right) d t^{\prime},
$$




\section{Abordagem de Langevin Ao Movimento Browniano}

onde $v_{0}$ é a velocidade da partícula em $t=0$.

Para calcular $v$ usa-se (A.15). Assim:

$$
\langle v\rangle=v_{0} e^{-\gamma t}
$$

Para a variância calcula-se primeiramente

$$
v-\langle v\rangle=e^{-\gamma t} \int_{0}^{t} e^{\gamma t^{\prime}} \xi\left(t^{\prime}\right) d t^{\prime} .
$$

Agora

$$
\begin{aligned}
(v-\langle v\rangle)^{2} & =e^{-2 \gamma t} \int_{0}^{t} \int_{0}^{t} e^{\gamma\left(t^{\prime}+t^{\prime \prime}\right)} \xi\left(t^{\prime}\right) \xi\left(t^{\prime \prime}\right) d t^{\prime} d t^{\prime \prime}, \mathrm{e} \\
\left\langle(v-\langle v\rangle)^{2}\right\rangle= & e^{-2 \gamma t} \int_{0}^{t} \int_{0}^{t} e^{\gamma\left(t^{\prime}+t^{\prime \prime}\right)}\left\langle\xi\left(t^{\prime}\right) \xi\left(t^{\prime \prime}\right)\right\rangle d t^{\prime} d t^{\prime \prime} \\
=e^{-2 \gamma t} \int_{0}^{t} \int_{0}^{t} e^{\gamma\left(t^{\prime}+t^{\prime \prime}\right)} & A \delta\left(t^{\prime}-t^{\prime \prime}\right) d t^{\prime} d t^{\prime \prime} \\
= & e^{-2 \gamma t} A \int_{0}^{t} e^{2 \gamma t^{\prime}} d t^{\prime} \\
& =\frac{e^{-2 \gamma t} A e^{2 \gamma t^{\prime}}}{2 \gamma} /{ }_{0}^{t} \\
& =\frac{A}{2 \gamma}\left(1-e^{-2 \gamma t}\right) .
\end{aligned}
$$

Assim, para tempos longos $(t \rightarrow \infty)$ tem-se

$$
\left\langle v^{2}\right\rangle-\langle v\rangle^{2}=A / 2 \gamma
$$

Também para tempos longos tem-se que $\langle v\rangle=0$, o que resulta numa velocidade quadrática 


\section{Abordagem de Langevin Ao Movimento Browniano}

média dada por

$$
\left\langle v^{2}\right\rangle=A / 2 \gamma
$$

A partir da teoria cinética dos gases, e do Teorema de Equipartição da Energia, tem-se que

$$
\frac{1}{2} m\left\langle v^{2}\right\rangle=\frac{1}{2} k_{B} T
$$

onde $k_{B}$ é a constante de Boltzmann e $T$ a temperatura absoluta. Comparando as duas últimas equações obtem-se

$$
A=\frac{2 \gamma k_{B} T}{m}
$$

Tinha-se que $C=A m^{2}$ e $\alpha=\gamma m$, assim

$$
C=2 \alpha k_{B} T
$$

Encontrado $C$, pode-se dar continuidade nos cálculos para encontrar-se o deslocamento quadrático médio (MSD). Em princípio tem-se

$$
\begin{array}{r}
v=\frac{d x}{d t} \\
x=x_{0}+\int_{0}^{t} v\left(t^{\prime}\right) d t^{\prime},
\end{array}
$$

onde $x_{0}$ é a posição inicial da partícula. Utilizando a equação (A.15) ficamos com

$$
\begin{aligned}
x & =x_{0}+v_{0} \int_{0}^{t} e^{-\gamma t^{\prime}} d t^{\prime}+\int_{0}^{t} e^{-\gamma t^{\prime}} \int_{0}^{t^{\prime}} \xi\left(t^{\prime \prime}\right) e^{\gamma t^{\prime \prime}} d t^{\prime \prime} d t^{\prime} \\
& =x_{0}+v_{0} \frac{1}{\gamma}\left(1-e^{-\gamma t}\right)+\int_{0}^{t} \xi\left(t^{\prime \prime}\right) e^{\gamma t^{\prime \prime}} \int_{t^{\prime \prime}}^{t} e^{-\gamma t^{\prime}} d t^{\prime} d t^{\prime \prime} \\
& =x_{0}+v_{0} \frac{1}{\gamma}\left(1-e^{-\gamma t}\right)+\frac{1}{\gamma} \int_{0}^{t} \xi\left(t^{\prime \prime}\right)\left(1-e^{\gamma\left(t^{\prime \prime}-t\right)}\right) d t^{\prime \prime}
\end{aligned}
$$




\section{Abordagem de Langevin Ao Movimento Browniano}

Usando (A.12) obtem-se o deslocamento médio da partícula

$$
\langle x\rangle=x_{0}+v_{0} \frac{1}{\gamma}\left(1-e^{-\gamma t}\right)
$$

Para se calcular o desvio quadrático médio, primeiramente faz-se

$$
x-\langle x\rangle=\frac{1}{\gamma} \int_{0}^{t} \xi\left(t^{\prime \prime}\right)\left(1-e^{\gamma\left(t^{\prime \prime}-t\right)}\right) d t^{\prime \prime}
$$

Agora

$$
(x-\langle x\rangle)^{2}=\frac{1}{\gamma^{2}} \int_{0}^{t} \int_{0}^{t} \xi\left(t^{\prime}\right) \xi\left(t^{\prime \prime}\right)\left(1-e^{\gamma\left(t^{\prime}-t\right)}\right)\left(1-e^{\gamma\left(t^{\prime}-t\right)}\right) d t^{\prime} d t^{\prime \prime}
$$

Usando (A.12) segue que

$$
\left\langle(x-\langle x\rangle)^{2}\right\rangle=\frac{A}{\gamma^{2}} \int_{0}^{t}\left(1-e^{\gamma\left(t^{\prime}-t\right)}\right)^{2} d t^{\prime} .
$$

Efetuando a integral tem-se

$$
\left\langle x^{2}\right\rangle-\langle x\rangle^{2}=\frac{A}{\gamma^{2}}\left[t-\frac{2}{\gamma}\left(1-e^{-\gamma t}\right)+\frac{1}{2 \gamma}\left(1-e^{-2 \gamma t}\right)\right]
$$

Para tempos longos $(t \rightarrow \infty)$ o primeiro termo é dominante, assim encontra-se que o desvio 


\section{Abordagem de Langevin Ao Movimento Browniano}

quadrático médio é proporcional a $t$, ou seja

$$
\begin{array}{r}
(\Delta x)^{2}=\frac{A}{\gamma^{2}} t \\
(\Delta x)^{2}=2 \frac{k_{B} T}{m \gamma} t \\
=2 D t
\end{array}
$$

que é conhecida como a relação de Einstein, onde $D$ é o coeficiente de difusão.

Considerando partículas, de raio $a$ imersas em um fluido de viscosidade $\eta$, o coeficiente $\alpha$ é dado pela Lei de Stokes

$$
\alpha=6 \pi \eta a,
$$

de forma que

$$
D=\frac{k_{B} T}{6 \pi \eta a}
$$

Assim, a partir da medida do MSD, é possível encontrar a viscosidade do meio

$$
\mathrm{MSD}=\frac{k_{B} T}{3 \pi a} \frac{1}{\eta} t
$$


Abordagem de Langevin Ao Movimento Browniano 


\section{Apêndice B}

\section{Relação de Stokes-Einstein Generalizada}

A resposta de um fluido a flutuações térmicas, obtida através da média do movimento de pequenas partículas dispersas sobre o fluido, dá uma boa representação da resposta do fluido interno a uma tensão cisalhante imposta. Assim, utilizando a equação de Langevin generalizada, o movimento de uma esfera em uma dimensão pode ser descrita como [90]:

$$
m \dot{v}(t)=f_{R}(t)-\int_{0}^{t} \xi\left(t-t^{\prime}\right) v\left(t^{\prime}\right) d t^{\prime}
$$

onde $m$ é a massa da esfera, $v(t)$ é a velocidade da esfera, o ponto denota derivada em relação ao tempo, $f_{R}(t)$ são as forças externas aleatórias e $\xi(t)$ é uma função memória causal que descreve a resposta viscoelástica de um fluido complexo incompressível e isotrópico. Fazendo a transformada de Fourier unilateral da eq. B.1, tem-se:

$$
\int_{0}^{\infty} m \dot{v}(t) e^{i \omega t} d t=\int_{0}^{\infty} f_{R}(t) e^{i \omega t} d t-\int_{0}^{\infty}\left[\int_{0}^{\infty} \xi\left(t-t^{\prime}\right) v\left(t^{\prime}\right) d t^{\prime}\right] e^{i \omega t} d t
$$

Usando que $\xi(t)=0$ para $t<0^{+}$, e convolução, $\left(\int_{0}^{\infty} f\left(t-t^{\prime}\right) g\left(t^{\prime}\right) d t^{\prime}\right)^{*}=f^{*} \cdot g^{*}$, fica-se 
com:

$$
\begin{gathered}
-m v(0)+i m \omega v^{*}(\omega)=f_{R}^{*}(\omega)-\xi^{*}(\omega) \cdot v^{*}(\omega) \\
+i m \omega v^{*}(\omega)+\xi^{*}(\omega) \cdot v^{*}(\omega)=f_{R}^{*}(\omega)+m v(0) \\
v^{*}(\omega)=\frac{f_{R}^{*}(\omega)+m v(0)}{i m \omega+\xi^{*}(\omega)}
\end{gathered}
$$

Multiplicando os dois lados da eq. B.5 por $v(0)$, tem-se:

$$
v(0) v^{*}(\omega)=\frac{v(0) f_{R}^{*}(\omega)+m v(0) v(0)}{i m \omega+\xi^{*}(\omega)} .
$$

Tirando a média (ensemble average):

$$
\left\langle v(0) v^{*}(\omega)\right\rangle=\frac{\left\langle v(0) f_{R}^{*}(\omega)\right\rangle+m\langle v(0) v(0)\rangle}{i m \omega+\xi^{*}(\omega)} .
$$

Usando o teorema de equipartição da energia, $m\langle v(t) v(t)\rangle=k_{B} T$, e que as forças aleatórias estão dissociadas de velocidades passadas, $\left\langle v(0) f_{R}(t)\right\rangle=0$, fica-se com:

$$
\left\langle v(0) v^{*}(\omega)\right\rangle=\frac{k_{B} T}{i m \omega+\xi^{*}(\omega)}
$$

O primeiro termo do denominador pode ser desconsiderado, pois para a maior parte dos materiais, as frequências são baixas. Este termo torna-se importante para frequências de MHz. Assim, encontra-se a função memória em função da correlação da velocidade:

$$
\xi^{*}(\omega)=\frac{k_{B} T}{\left\langle v(0) v^{*}(\omega)\right\rangle}
$$




\section{Relação de Stokes-Einstein Generalizada}

Usando a transformada de Fourier do deslocamento quadrático médio:

$$
\mathscr{F}_{u}\left\{\left\langle\Delta r^{2}(t)\right\rangle\right\}=\frac{6}{(i \omega)^{2}} \mathscr{F}_{u}\{\langle v(0) v(t)\rangle\}
$$

chega-se a:

$$
\xi^{*}(\omega)=\frac{6 k_{B} T}{(i \omega)^{2} \mathscr{F}_{u}\left\{\left\langle\Delta r^{2}(t)\right\rangle\right\}} .
$$

Transformando para viscosidade via Stokes:

$$
\eta^{*}(\omega)=\frac{\xi^{*}(\omega)}{6 \pi a}
$$

e para o módulo complexo de cisalhamento:

$$
\begin{gathered}
G^{*}(\omega)=i \omega \eta^{*}(\omega), \\
G^{*}(\omega)=\frac{k_{B} T}{\pi a(i \omega) \mathscr{F}_{u}\left\{\left\langle\Delta r^{2}(t)\right\rangle\right\}} .
\end{gathered}
$$

O módulo complexo de cisalhamento, $G^{*}(\omega)=G^{\prime}(\omega)+i G^{\prime \prime}(\omega)$, é definido como a razão entre a tensão e a deformação dependentes da frequência. Quando em fase, temos a parte real, $G^{\prime}$, sendo o módulo de armazenagem, relacionado a elasticidade, e quando fora de fase, a parte imaginária, $G^{\prime \prime}$, sendo o módulo de perda, relacionado à viscosidade.

Toda representação de viscoelasticidade linear para um material isotrópico pode ser representado por uma única função escalar $G_{r}(t)$, que é a relaxação temporal de uma tensão devido a pequenos passos de distensões aplicadas normalizadas pela amplitude da distensão. Equivalentemente temos que $G^{*}(\omega)=i \omega \mathscr{F}_{u}\left\{G_{r}(t)\right\}$, onde a transformada unilateral complexa de Fourier de $G_{r}(t)$ é: $\mathscr{F}_{u}\left\{G_{r}(t)\right\} \equiv G_{r}^{*} \equiv \int_{0}^{\infty} d \hat{t} G_{r}(\hat{t}) e^{-i \omega \hat{t}}$. Sua parte real e imaginária definem o módulo de armazenagem e perda respectivamente, como dito anteriormente. 


\section{B.1 Aproximação de Mason}

Ambos componentes elásticos e viscosos são usualmente significantes, embora suas contribuições relativas dependam da frequência, entretanto, diferente de fluidos simples, essas frequências são tipicamente baixas para serem acessíveis experimentalmente [22]. Tradicionalmente, $G^{*}(\omega)$ é determinado mecanicamente, por exemplo, uma tensão é aplicada e a distensão induzida é medida [22]. Assim, o alcance da frequência é limitado, ou seja, nenhuma técnica pode medir $G^{*}(\omega)$ com um extenso intervalo [22].

Desta maneira, os dados experimentais têm um intervalo limitado, mas a transformada de Fourier requer um alcance infinito. Isso pode levar a erros, principlamente nos limites das escalas assecíveis. Para evitar erros, Mason [90] derivou estimativas algébricas para $G^{*}(\omega)$ baseado na expansão local do $\left\langle\Delta r^{2}(t)\right\rangle$ em lei de potência em torno da frequência de interesse. Assim:

$$
\left\langle\Delta r^{2}(t)\right\rangle \approx\left\langle\Delta r^{2}(1 / \omega)\right\rangle(\omega t)^{\alpha(\omega)}
$$

onde $\left\langle\Delta r^{2}(1 / \omega)\right\rangle$ é a magnitude de $\left\langle\Delta r^{2}(t)\right\rangle$ a $t=1 / \omega \mathrm{e}$

$$
\left.\alpha(\omega) \equiv \frac{d \ln \left\langle\Delta r^{2}(t)\right\rangle}{d \ln t}\right|_{t=1 / \omega}
$$

é o expoente da lei de potência que descreve a inclinação do logaritmo de $\left\langle\Delta r^{2}(t)\right\rangle$ a $t=1 / \omega$. Esta inclinação varia de 0 a 1 , onde 0 corresponde a um confinamento elástico, enquanto 1 corresponde a uma difusão viscosa.

Calculando a transformada de Fourier da lei de potência, tem-se:

$$
\mathscr{F}_{u}\left\langle\Delta r^{2}(t)\right\rangle=\int_{0}^{\infty}\left\langle\Delta r^{2}(1 / \omega)\right\rangle(\omega t)^{\alpha(\omega)} e^{-i \omega t} d t
$$




\section{Relação de Stokes-Einstein Generalizada}

$$
\begin{gathered}
=\left\langle\Delta r^{2}(1 / \omega)\right\rangle \int_{0}^{\infty}(\omega t)^{\alpha(\omega)} e^{-i \omega t} d t \\
=\left\langle\Delta r^{2}(1 / \omega)\right\rangle \frac{1}{i^{\alpha(\omega)}} \int_{0}^{\infty}(i \omega t)^{\alpha(\omega)} e^{-i \omega t} d t .
\end{gathered}
$$

Usando $u=i \omega t$, assim $d u=i \omega d t$, ou $d t=d u / i \omega$. Continuando:

$$
\mathscr{\mathscr { F } _ { u }}\left\langle\Delta r^{2}(t)\right\rangle=\left\langle\Delta r^{2}(1 / \omega)\right\rangle \frac{1}{i^{\alpha(\omega)} i \omega} \int_{0}^{\infty} u^{\alpha(\omega)} e^{u} d u
$$

Sabe-se que $\Gamma(z)=\int_{0}^{\infty} t^{z-1} e^{-t} d t$, e usando $\alpha(\omega)=z-1$, então $z=\alpha(\omega)+1$, e:

$$
\mathscr{F}_{u}\left\langle\Delta r^{2}(t)\right\rangle=\left\langle\Delta r^{2}(1 / \omega)\right\rangle \frac{1}{i^{\alpha(\omega)} i \omega} \Gamma(1+\alpha(\omega))
$$

Portanto,

$$
i \omega \mathscr{F}_{u}\left\langle\Delta r^{2}(t)\right\rangle \approx\left\langle\Delta r^{2}(1 / \omega)\right\rangle \Gamma(1+\alpha(\omega)) i^{-\alpha(\omega)} .
$$

Substituindo na eq. B.14, fica-se com:

$$
G^{*}(\omega)=\frac{k_{B} T}{\pi a\left\langle\Delta r^{2}(1 / \omega)\right\rangle \Gamma(1+\alpha(\omega)) i^{-\alpha(\omega)}} .
$$

E utilizando equações de Euler, encontra-se:

$$
\begin{gathered}
G^{\prime}(\omega)=\left|G^{*}(\omega)\right| \cos (\pi \alpha(\omega) / 2) \\
G^{\prime \prime}(\omega)=\left|G^{*}(\omega)\right| \operatorname{sen}(\pi \alpha(\omega) / 2),
\end{gathered}
$$

onde

$$
\left|G^{*}(\omega)\right| \approx \frac{k_{B} T}{\pi a\left\langle\Delta r^{2}(1 / \omega)\right\rangle \Gamma[1+\alpha(\omega)]}
$$




\section{Relação de Stokes-Einstein Generalizada}

Essas equações são muito úteis para a interpretações físicas dos módulos, em relação ao MSD. Quando a esfera se move difusivamente, $\alpha$ se aproxima de um, e $G^{\prime \prime}$ domina, enquanto que quando a esfera é confinada por uma estrutura elástica do fluido complexo, $\alpha$ se aproxima de zero, e $G^{\prime}$ domina [90]. 


\section{Apêndice C}

\section{Teoria dos Materias Vítreos Moles}

Sollich desenvolveu seu modelo usando o trabalho de Bouchaud que usa uma descrição intuitiva de vidro: um elemento individual num panorama com armadilhas de várias profundidades $E$. Um elemento pode pular de seu poço para outro, e esses eventos de saltos são ativados por flutuações térmicas, da ordem de $k_{B} T$. Diferentemente de Bouchaud, para Sollich os poços são mais profundos, e é improvável que os elementos escapem somente por energia térmica. Ao invés disso, os elementos são agitados por uma fonte de energia não térmica e que pode ser representada por uma temperatura efetiva, ou nível de ruído, $x$. Assim, a ativação seria devido a interações entre elementos vizinhos: um rearranjo em algum lugar no material pode propagar e causar rearranjos em outros locais [25].

A equação do movimento de Bouchaud para a probabilidade de encontrar um elemento em uma armadilha de profundidade $E$ no tempo $t$ é dada por [25]:

$$
\frac{\partial}{\partial t} P(E, t)=-\Gamma_{0} e^{-E / x} P(E, t)+\Gamma(t) \rho(E)
$$

onde $x$ é a temperatura efetiva. O primeiro termo do lado direito descreve elementos saltando 
de suas armadilhas, $\Gamma_{0}$ é a frequência de tentativas por salto, e $\exp (-E / x)$ é o fator ativação correspondente. O segundo termo representa o estado desses elementos após o salto, onde $\rho(E)$ é a distribuição das profundidades das armadilhas. A taxa de saltos em armadilhas de profundidade $E$ é então $\rho(E)$ vezes a taxa de salto total, dada por:

$$
\Gamma(t)=\Gamma_{0}\left\langle e^{(-E / x)}\right\rangle_{P}=\Gamma_{0} \int P(E, t) e^{(-E / t)} d E
$$

Sollich usou o modelo de Bouchaud incorporando deformação e fluxo a equação. O modelo de Sollich, então, retrata um material formado por um grande número de elementos que estão presos em gaiolas, armadilhas, formadas por seus vizinhos. A idéia é a mesma apresentada anteriormente, mas, para descrever reologia e fluxo, Sollich incorpora uma variável de deslocamento, distensão, local $l$ (se $l=0$ não existe distensão) [25]. Aplicando uma tensão no material, cada elemento passa a ter uma deformação elástica a partir do local de equilíbrio da configuração até que alcance um ponto $l_{y}$, depois do qual o rearranjo ocorre.

Assumindo que cada elemento seja linearmente elástico, com uma constante elástica $k$, a tensão nos elementos evolui com $k l$, e a energia elástica que pode ser armazenada nos elementos é $k l_{y}^{2} / 2$. Assumindo que a taxa de distensão microscópica, $l$, seja igual a taxa de distensão macroscópica, $\dot{\gamma}$, o estado do sistema no tempo $t$ é caracterizado pela probabilidade de encontrar um elemento em uma armadilha de profundidade $E$ e uma tensão local $l$ no tempo $t$. Assim, a probabilidade evolui como [25]:

$$
\frac{\partial}{\partial t} P(E, l, t)=-\dot{\gamma} \frac{d P}{d l}-\Gamma_{0} P e^{\left(-E-k l^{2} / 2\right) / x}+\Gamma_{0} \Gamma(t) \rho(E) \delta(l),
$$

onde

$$
\Gamma(t)=\Gamma_{0} \iint P(E, l, t) e^{\left(-E-k l^{2} / 2\right) / x} d E d l
$$


O primeiro termo do lado direito da equação (C.3) descreve o movimento dos elementos entre rearranjos, com uma taxa de distensão local igual a macroscópica $\dot{l}=\dot{\gamma}$. O segundo e terceiro termos tem os mesmos significados descritos anteriormente. Note que o terceiro termo agora contém a função $\delta(l)$, devido à suposição que a distensão local torna-se zero imediatamente depois da relaxação [25]. Finalmente, a resposta reológica, que é a distensão macroscópica, é obtida como valor esperado da tensão local:

$$
\sigma=\iint k l P(E, l, t) d l d E
$$


Teoria dos Materias Vítreos Moles 


\section{Apêndice D}

\section{Cultura Celular e Protocolo Experimental para Difusão Anômala e OMTC}

\section{D.1 Meio de Cultura Celular}

O meio para cultura utilizado varia para cada tipo de célula. Geralmente este é complementado com $10 \%$ de soro fetal bovino e $1 \%$ de antibiótico. Os meios utilizados neste trabalho estão mostrados na Tab. D.1.

\begin{tabular}{cc}
\hline Tipo celular & Meio de cultura \\
\hline Beas (Cap. 3) & Nutrient Mixture F-12 HAM (Sigma) \\
HASM (Cap. 4) & DMEM high glucose (Gibco) \\
RASM (Cap. 6 e Cap. 8.2) & DMEM high glucose (Gibco) \\
Cardiomiócitos (Cap. 8.1) & DEMEM low glucose + Meio 199 (E) (CultiLab) \\
MDCK (Cap. 8.2) & DMEM (Gibco) low glucose \\
\hline \hline
\end{tabular}

Tabela D.1. Tipos de meio de cultura para os tipos celulares utilizados neste projeto. 
Cultura Celular e Protocolo Experimental para Difusão Anômala e OMTC

\section{D.2 Protocolo de Subcultivo e Manutenção de Células em Cultura Permanente}

Todo o procedimento deve ser efetuado dentro de um fluxo laminar. Para evitar contaminação utilizar pipetador automático. ATENÇÃO: Para cada pipetagem usar nova pipeta. Nunca retornar uma pipeta usada para o frasco de meio de cultura ou PBS.

Abaixo os materiais de manutenção de células:

Materiais estéreis:

- meio de cultura;

- pipetas de $10 \mathrm{~m} \ell$;

- frascos de cultura;

- tubo Eppendorf de $1 \mathrm{~m} \ell$;

- tubo Falcon de $50 \mathrm{~m} \ell$.

Materiais não estéreis:

- pipetador automático;

- luvas;

- avental;

- gazes;

- recipientes de descarte do meio e de pipetas; 


\section{Cultura Celular e Protocolo Experimental para Difusão Anômala e OMTC}

- caneta pemanente;

- cadernos;

- protocolos;

\section{D.2.1 Protocolo Prévio}

1. Limpar o interior do fluxo laminar com álcool $70 \%$ e toda a superfície de trabalho;

2. Ligar a luz UV do fluxo por 15 minutos antes de começar o procedimento;

3. Esquentar o banho Maria a $37^{\circ} \mathrm{C}$;

4. Retirar o meio da geladeira e esquentá-lo no banho Maria a $37^{\circ} \mathrm{C}$;

5. Desligar a luz UV e colocar dentro do fluxo todo o material que precisar, deixando o material em posição acessível.

\section{D.2.2 Protocolo de Subcultivo e Manutenção de Células em Cultura Per- manente}

Materiais (assumindo frasco de cultura de $75 \mathrm{~cm}^{2}$ ):

1. $50 \mathrm{~m} \ell$ de meio de cultura e $10 \mathrm{~m} \ell$ PBS (temp. ambiente/geladeira);

2. $3 \mathrm{~m} \ell$ Tripsina (temperatura $37^{\circ} \mathrm{C}$ );

3. Pipetas descartáveis;

4. Tubos Falcon de $50 \mathrm{~m} \ell$; 


\section{Cultura Celular e Protocolo Experimental para Difusão Anômala e OMTC}

5. 2 frascos de cultura;

\section{Protocolo:}

1. Seguir o protocolo prévio de limpeza;

2. Desprezar o meio de cultura da garrafa de células no descarte;

3. Lavar a camada celular com $10 \mathrm{~m} \ell$ PBS, removendo todo o tampão duas vezes cada vez com $5 \mathrm{~m} \ell$. Pipetar o PBS sempre do lado contrario do tapete celular;

4. Adicionar $2 \mathrm{~m} \ell$ de tripsina. Incubar a $37^{\circ} \mathrm{C}$ por aproximadamente 2 a 5 minutos (o tempo de incubação com tripsina dependerá muito do tipo celular). Movimentar a garrafa de células cuidadosamente;

- 1,5 - $2 \mathrm{~m} \ell$ de tripsina: frasco de $25 \mathrm{~cm}^{2}$

- $3 \mathrm{~m} \ell$ de tripsina: frasco de $75 \mathrm{~cm}^{2}$

- $5 \mathrm{~m} \ell$ de tripsina: frasco de $150 \mathrm{~cm}^{2}$

5. Fechar a garrafa e deixá-la na estufa a $37^{\circ} \mathrm{C}$ por 5-10 minutos. Observar o descolamento das células (auxiliar batendo com cuidado na lateral da garrafa para elas soltarem da superfície);

6. Olhar no microscópio se elas ainda estão aderidas no frasco;

7. Ressuspender as células em $10 \mathrm{~m} \ell$ de meio de cultura. Homogeneizar bem com a pipeta para dispersar as células;

8. Coletar o fluido (meio + células), colocando num tubo Falcon de $50 \mathrm{~m} \ell$;

9. Centrifugar a suspensão a $1200 \mathrm{rpm}$ por 3 minutos e descartar o sobrenadante contendo a tripsina inativa; 


\section{Cultura Celular e Protocolo Experimental para Difusão Anômala e OMTC}

10. Ressuspender as células em meio de cultura em $10 \mathrm{~m} \ell$;

11. Colocar $5 \mathrm{~m} \ell$ em cada frasco de $75 \mathrm{~cm}^{2}$ e completar até $10 \mathrm{~m} \ell$ em cada frasco;

12. Não fechar a garrafa totalmente;

13. Identificar a garrafa com a linhagem, número da passagem, data;

14. Incubar a $37^{\circ} \mathrm{C}$;

15. Repetir o procedimento quando as células se encontrarem numa porcentagem de $90 \%$ de confluência.

\section{D.3 Mudança de Meio de Cultura}

Materiais para mudança de meio:

Estéreis:

- meio de cultura;

- e pipetas de $10 \mathrm{~m} \ell$.

Não Estéreis:

- pipetador;

- luvas;

- avental;

- gazes; 
- recipientes de descarte de meio e de pipetas;

- caneta permanente;

- cadernos;

- protocolos;

\section{Procedimentos:}

1. Examinar a cultura cuidadosamente no microscópio, observando sinais de contaminação e deterioração;

2. Verificar o pH (mudança na cor), densidade celular ou concentração (câmara de Neubauer);

3. Tomar uma pipeta estérea de $10 \mathrm{~m} \ell$;

4. Aspirar o meio e descartá-lo;

5. Lavar o frasco com meio de cultura aproximadamente com $10 \mathrm{~m} \ell$, mexer cuidadosamente, aspirar o meio de cultura e descartá-lo;

6. Pegar uma pipeta nova e adicionar $10 \mathrm{~m} \ell$ de meio aquecido a $37^{\circ} \mathrm{C}$;

7. Descartar a pipeta;

8. Não fechar completamente o frasco de cultura;

9. Incubar a cultura de células a $37^{\circ} \mathrm{C}$;

10. Repetir este procedimento a cada 48 horas.

\section{Substituir o meio de cultura caso:}




\section{Cultura Celular e Protocolo Experimental para Difusão Anômala e OMTC}

1. Diminuição no $\mathrm{pH}$ : muitas células param o crescimento quando o $\mathrm{pH}$ desce de 7.0 para 6.5, perdem a viabilidade para um $\mathrm{pH}$ entre 6.5 e 6.0. O controle disso se faz olhando a mudança de cor do meio;

2. Concentração celular: culturas de células em uma concentração alta, diminui o meio mais rápido do que aqueles com uma baixa concentração. Este fator é geralmente evidente na taxa de variação do $\mathrm{pH}$, mas nem sempre;

3. Tipo de células: células normais normalmente param de se dividir a uma densidade alta por causa da aglomeração, depleção do fator de crescimento, dentre outras razões. Mas estas podem se deteriorar se o meio não é trocado ou não são replicadas;

4. Deterioração morfológica: este fator deve ser antecipado pelo exame regular e familiaridade com a linha de celular. Se a deterioração é permitida, poderá ser irreversível, pois as células tendem a entrar em apoptose;

A substituição do meio deve ser mais ou menos cada 48 horas, o meio possibilita a nutrição adequada das células e a eliminação de metabólitos secretados para o meio.

\section{D.3.1 Concentração celular}

A contagem de células em câmara de Neubauer é feita da seguinte maneira:

1. Colocar a lamínula sobre a área marcada na câmara de contagem. Usar lamínulas especiais que fornecem a profundidade correta da câmara de contagem. Não usar lamínulas comuns;

2. Homogeneizar bem a suspensão celular e transferir com esterilidade $0,1 \mathrm{~m} \ell$ para um pequeno tubo Eppendorf de $1 \mathrm{~m} \ell$; 
Cultura Celular e Protocolo Experimental para Difusão Anômala e OMTC

3. Adicionar $0.3 \mathrm{~m} \ell$ de corante azul de tripan $0.2 \%$ ao tubo, obtendo assim uma diluição $1 / 4$

4. Misturar os conteúdos e retirar uma alíquota de $0.5 \mathrm{~m} \ell$ com a pipeta;

5. Encostando a ponta da pipeta na borda da lamínula, preencher cuidadosamente a câmara de contagem. O liquido deve preencher apenas um lado da câmara e não deve chegar aos canais de cada lado da área de contagem;

6. Deixar as células sedimentarem por 2 minutos;

7. Focalizar a área demarcada da câmera de contagem com a objetiva de menor aumento. Nas áreas 1, 2, 3 e 4, o volume com a lamínula colocada corresponde a $0.1 \mathrm{~mm}^{3}$;

8. Contar as células nas áreas de um lado da câmara de contagem e dividir o valor por 4 para obter a média;

9. Como a suspensão foi inicialmente diluída a $1 / 4$, o número de células contadas será igual à média multiplicada pelo fator de diluição, no caso 4;

10. Para obter o número de células/m $\ell$, multiplicar, corrigir o valor obtido por 10000, pois: $1 \mathrm{~m} \ell=1000 \mathrm{~mm}^{3}$

Na câmara de Neubauer obtemos o número de células por $0.1 \mathrm{~mm}^{3}$, então devemos multiplicar por 10 , portanto $10 \times 1000$;

11. Assim temos: $\mathrm{n}^{o}$ de células $/ \mathrm{m} \ell=\left(\mathrm{n}^{o}\right.$ total de células $/ \mathrm{n}^{o}$ de quadrantes contados $) \times$ fator de diluição $\times 10000$.

\section{Critérios para contagem:}

- Enumerar células com núcleo bem visível; 


\section{Cultura Celular e Protocolo Experimental para Difusão Anômala e OMTC}

- Contar células isoladas como uma célula;

- Contar grumos constituídos por células facilmente distinguíveis por seus núcleos e citoplasmas como grupos de células isoladas e contar cada célula;

- Grumos, cujas células são difíceis de serem distinguidas umas das outras, devem ser contados como um único grupo.

\section{D.4 Descongelamento de Células em Ampolas}

\section{Procedimento:}

1. Retirar a ampola ou tubo do botijão de nitrogênio líquido e colocá-lo imediatamente em banho-maria a $37^{\circ} \mathrm{C}$ para o descongelamento;

2. Pipetar o conteúdo da ampola e colocar imediatamente o material desta em uma garrafa de cultivo celular de $25 \mathrm{~cm}^{2} \operatorname{com} 10 \mathrm{~m} \ell$ de meio de cultura com $10 \%$ de soro fetal bovino e antibiótico. No caso de tubo, colocar o conteúdo em um Roux com 15 m $\ell$ de meio de cultura com $10 \%$ de soro fetal bovino e antibiótico;

3. Colocar o material na estufa de células para o crescimento e formação do tapete celular;

4. Anotar no livro de registro as ampolas ou tubos retirados para o descongelamento.

\section{D.5 Preparo para OMTC ou Difusão Anômala}

\section{Procedimento:}




\section{Cultura Celular e Protocolo Experimental para Difusão Anômala e OMTC}

1. Limpar com álcool $70 \%$ a superfície de trabalho e depois levar o material de trabalho;

2. Previamente deixar o peptídeo (RGD) se descongelar à temperatura ambiente durante 1 hora;

3. Organizar todo o material e desinfetar com álcool.

\section{Materiais:}

\section{Estéreis:}

- ponteiras de $1000 \mu \ell$ e $200 \mu \ell$;

- placa de 96 poços;

- buffer carbonato;

- PBS (buffer fosfato salina);

- meio (dependendo do tipo celular);

- Tripsina/EDTA;

- $50 \mu \mathrm{g}$ ou $10 \mu \ell$ do RGD;

- colágeno ou gelatina.

Não estéreis:

- DMSO (dimetilsulfoxido);

- pipetador;

- luvas; 


\section{Cultura Celular e Protocolo Experimental para Difusão Anômala e OMTC}

- recipiente com álcool a 70\%;

- gazes;

- tesoura;

- caneta permanente;

- placa de Petri;

- protocolos;

- cadernos.

A parte experimental consiste em vários procedimentos:

\section{D.5.1 Revestimento de 96 poços com Colágeno}

1. Prepare a solução de gelatina ou matriz gel para o revestimento (a solução de revestimento vai depender do tipo celular) (a) Concentração de gelatina ou matriz gel para revestimento: $500 \mathrm{mg}$ por $100 \mu \ell$ em Buffer carbonato (b) Tomar $10 \mathrm{~m} \ell$ da solução de revestimento para 100 poços (100 $\mu \ell$ por 96-poços), tomar $16.7 \mu \ell$ da solução stock de gelatina ou matriz gel e diluir em $10 \mathrm{~m} \ell$ de buffer carbonato, misturar bem a solução no vortex entre 10-30 segundos

2. Lavar cada poço (96 poços de frasco de cultura) com $300 \mu \ell$ PBS;

3. Adicionar $100 \mu \ell$ da solução de gelatina ou matriz gel dentro de cada poço;

4. Incubar durante a noite $(24 \mathrm{~h})$ na geladeira $\left(4^{\circ} \mathrm{C}\right)$ antes do uso. 


\section{D.5.2 Revestimento das esferas com o peptídeo RGD}

Preparar o material:

- Buffer carbonato para solução de revestimento;

- PBS para lavar;

- $50 \mu \mathrm{g}$ ou $10 \mu \ell$ de RGD que contém o peptídeo (peptídeo 2000) por m $\ell$ de esferas ferrimagnéticas.

A conservação do peptídeo quando esta herméticamente fechado deve se conservar no freezer a $-20^{\circ} \mathrm{C}$ ou $-80^{\circ} \mathrm{C}$.

Para preparação do peptídeo seguir os seguintes passos:

\section{Realização da solução:}

1. abrir o frasco do RGD na cabine de fluxo laminar;

2. pesar $10 \mathrm{mg}$ do peptídeo em um recipiente;

3. manter o resto do pó que ficou no frasco fechado em $-20^{\circ} \mathrm{C}$;

4. adicionar o DMSO (dimetilsulfoxido) ao pó do peptídeo para disolve-lo até chegar a uma concentração final de $5 \mathrm{mg} / \mathrm{m} \ell$;

5. manter a solução de uso diário a $4^{\circ} \mathrm{C}$ e a $-20^{\circ} \mathrm{C}$ para armazenamento a longo prazo.

Exemplo de cálculo: Precisamos chegar a uma concentração final de $5 \mathrm{mg} / \mathrm{m} \ell$. Em nosso caso temos $13.9 \mathrm{mg}$, assim: 


\section{Cultura Celular e Protocolo Experimental para Difusão Anômala e OMTC}

$$
\begin{aligned}
& 5 \mathrm{mg} \rightarrow 1 \mathrm{~m} \ell 13,9 \rightarrow \mathrm{y} \\
& \mathrm{y}=(1 \mathrm{~m} \ell \times 13.9 \mathrm{mg}) / 10 \mathrm{mg}=2.78 \mathrm{~m} \ell \text { de DMSO para } 5 \mathrm{mg} / \mathrm{m} \ell .
\end{aligned}
$$

Depois de preparar o peptídeo a $5 \mathrm{mg} / \mathrm{m} \ell$, prepara-se $1 \mathrm{mg}$ de esferas tendo em conta que: te$\operatorname{mos} 12.59 \mathrm{mg} / \mathrm{m} \ell$ de esferas ferrimagnéticas no estoque inicial. Assim, se temos $12.59 \mathrm{mg} / \mathrm{m} \ell$, precisamos encontrar quantos $\mathrm{m} \ell$ 's necessitaríamos para preparar $1 \mathrm{mg}$ de esferas. Desta maneira:

$$
\mathrm{y}=(1 \mathrm{mg} \times 1 \mathrm{~m} \ell) / 12.59 \mathrm{mg}=0,079 \mathrm{~m} \ell=79 \mu \ell \text { da solução estoque para } 1 \mathrm{mg} \text { de esferas. }
$$

\section{Para preparar $1 \mathrm{mg}$ de esferas:}

1. colocar no vórtex a solução estoque de esferas em etanol para dispersar e separar as esferas em agregados;

2. extrair o volume necessário da solução estoque de esferas $(79 \mu \ell)$;

3. calcular base na densidade das esferas da solução estoque para obter $1 \mathrm{mg}$ de esferas, após colocar o conteúdo num tubo para centrifugar;

4. agregar PBS suficiente para obter um volume final de $1 \mathrm{~m} \ell(921 \mu \ell)$;

5. lavar as esferas duas vezes com PBS na velocidade mais alta da centrifuga até que as esferas fiquem no fundo, se coloca de novo $1 \mathrm{~m} \ell$ com PBS. Depois de 2 lavadas com PBS substituir com $1 \mathrm{~m} \ell$ de buffer carbonato;

6. sonicar para quebrar agregados que se encontrem na solução das esferas;

7. adicionar $50 \mathrm{mg}$ do peptídeo ( $10 \mu \ell$ de $5 \mathrm{mg} / \mathrm{m} \ell$ da solução de RGD) dentro de $1 \mathrm{mg}$ de esferas (em $1 \mathrm{~m} \ell$ de buffer carbonato);

8. marcar o tubo e colocá-lo dentro da geladeira no rotor e girar o tubo durante a noite. 


\section{Cultura Celular e Protocolo Experimental para Difusão Anômala e OMTC}

\section{D.5.3 Cultivo de Células em 96 poços}

Este procedimento deve demorar aproximadamente uma hora.

1. aquecer o meio de cultura e tripsina (20 minutos);

2. lavar o colágeno que esta revestindo os poços: (a) $2 \times \operatorname{com} 300 \mu \ell$ de PBS frio (b) depois, substituir com $100 \mu \ell$ PBS

3. separar células: (a) Tomar as células epiteliais em uma garrafa T75 do incubador; (b) Examinar a condição das células no microscópio antes de usá-las; (c) Remover o meio de cultivo da garrafa; (d) Lavar as células em $5 \mathrm{~m} \ell$ de meio aquecido e removê-lo; (e) Adicionar $1 \mathrm{~m} \ell$ de solução de tripsina/EDTA em cada garrafa de células confluentes e distribuir a solução de tripsina sobre o filme celular; (f) Colocar a garrafa dentro do incubador aproximadamente por 2-5 minutos. (g) Depois, olhar se as células são separadas do substrato. Bater o frasco ate elas se desprender, olhar as células no microscópio para saber se desprenderam ou não; (h) Uma vez as células estejam flutuando, manter este passo o mínimo possível, e adicionar $10 \mathrm{~m} \ell$ de meio de cultura dentro do frasco para deter a tripsinização; (i) Agitar as células com o pipetador as células em suspensão mais o menos 10 vezes;

4. contagem de células (a) Transferir a suspenção celular num tubo falcon de $15 \mathrm{~m} \ell$; (b) Separar as células do meio por centrifugação a $1200 \mathrm{rpm}$ com $4^{\circ} \mathrm{C}$ por 3 minutos; (c) Remover o meio; (d) Adicionar $2 \mathrm{~m} \ell$ de meio sem soro fetal dentro do tubo, ressuspender 10 vezes; (e) Contagem das células:

i. Tomar $100 \mu \ell$ das células em suspenção do tubo centrifugado; ii. Colocar as células em suspenção na câmara de Neubauer; iii. Cada quadrado da câmara representa um volume total de $0,1 \mathrm{~mm}^{3}$ (ver anexo 1); iv. Se a média do número de células por quadrado é $X$ temos $X 10^{4}$ células/m $\ell$; v. Queremos 20000 células p/poço: volume da solução = 


\section{Cultura Celular e Protocolo Experimental para Difusão Anômala e OMTC}

2000/X $\mu \ell$; vi. Adicionar $50 \mu \ell$ de solução celular em cada poço;

5. encher os poços com meio de cultura especifico para cada tipo de célula, cada poço ficara com $200 \mu \ell$ de volume;

6. colocar a placa com células dentro do incubador por mais ou menos 4 horas, usualmente toda a noite antes do experimento.

\section{D.5.4 Adesão das Esferas nas Células}

Para obtermos a adesão das esferas nas células, temos os seguintes passos:

1. aquecer meio de cultura;

2. tomar a quantidade de esferas que você precisar: (a) a concentração de esferas é $1 \mathrm{mg} / \mathrm{m} \ell$; (b) a quantidade desejada de esferas é $10 \mu \mathrm{g} /$ poço;

3. limpar as esferas em 3 tempos com meio de cultura: (a) substituir o meio das esferas por meio sem soro fetal; (b) vórtex; (c) centrifugar e substituir o meio;

4. lavar os 96 poços: lavar a placa celular com $200 \mu \ell$ de meio sem soro fetal aquecido por 10 minutos;

5. aderir $10 \mu \ell$ (ajustar para fazer a deposição ideal) de esferas em cada poço e incubar por 15-20 minutos;

6. lavar os poços com $200 \mu \ell$ de meio sem soro fetal aquecido;

7. substituir com $100 \mu \ell$ de meio sem soro fetal aquecido;

8. incubar os poços por 5-10 minutos;

9. proceder o experimento com as células. 
Cultura Celular e Protocolo Experimental para Difusão Anômala e OMTC 


\section{Apêndice E}

\section{O software da OMTC}

O equipamento de OMTC não é um produto comercial, cada um de seus componetes: magnetizador, microcâmara de incubação, magnetizador, câmera CCD, placa de aquisição, e computador, foram comprados separadamente e montados pelo professor Adriano M. Alencar. A integração dos equipamentos foi feita via um software desenvolvido no laboratório $\mathrm{LabM}^{2}$. A maioria do colaboradores no exterior, controlam o equipamento de OMTC utilizando LabView ${ }^{\circledR}$ em plataforma Windows ${ }^{\circledR}$. Essa combinação provoca uma limitação fazendo com que o sistema não seja capaz de manipular acima de $15 \mathrm{fps}$ (frames por segundo). Nosso sistema foi 100\% desenvolvido em C ++ em plataforma Linux, Fig. E.0-1, possibilitando chegar a $30 \mathrm{fps,}$ atualmente limitado pela velocidade da câmera CCD (Pike AVT), ou seja o dobro que os colegas no exterior conseguem. Com a nova câmera (Andor Neo sCMOS), pode-se chegar a $100 \mathrm{fps,}$ colocando o LabMㄹ em uma posição de liderança nessa tecnologia.

O software utiliza uma cálculo de centro de massa para encontrar a posição da microesfera. O centro de massa é calculado a cada frame, resultando no posicionamento das microesferas por tempo. Ele é usado tanto para os experimentos de OMTC como para os experimentos de 


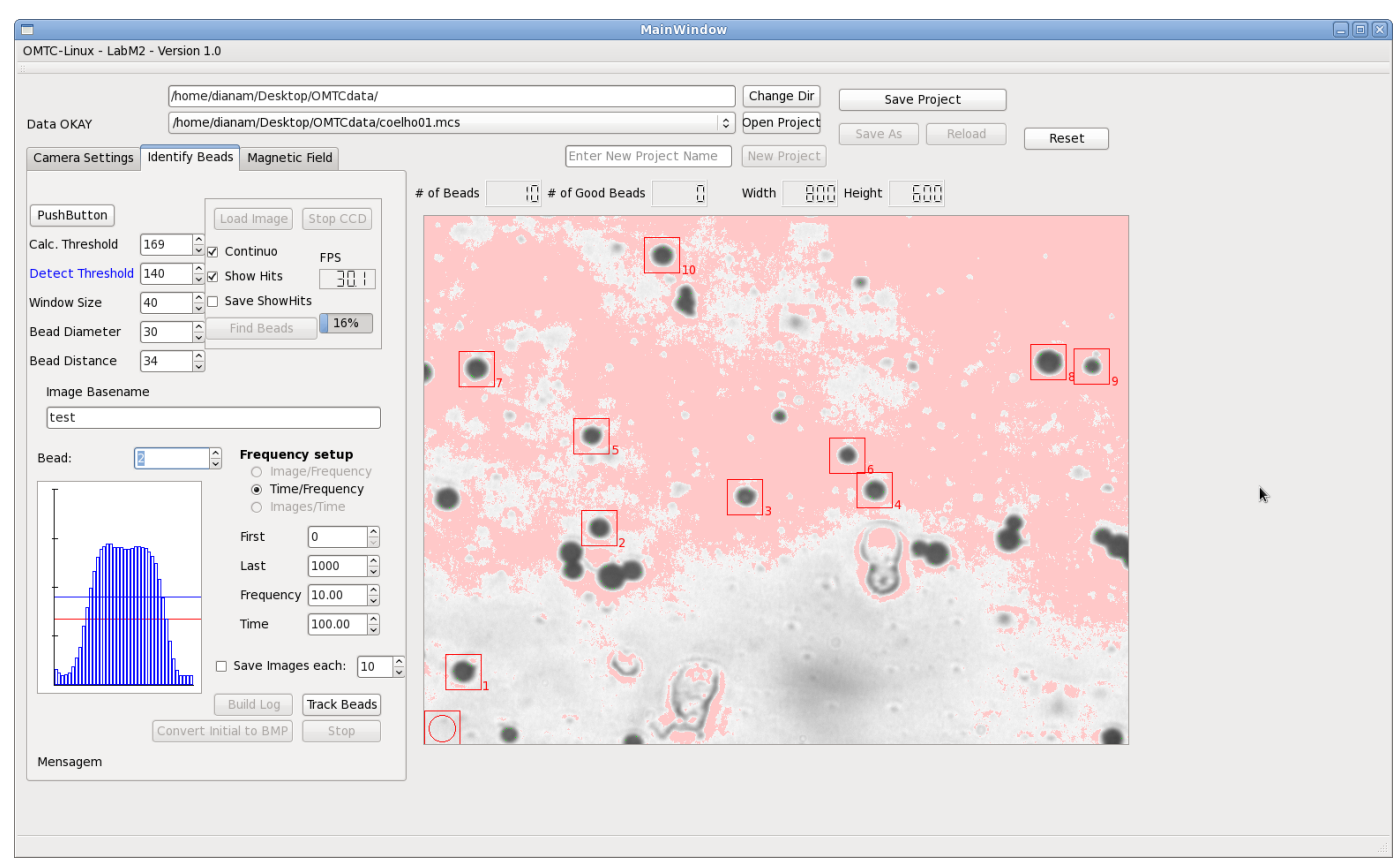

Figura E.0-1. Foto de uma tela do software que controla o OMTC. Esse software foi $100 \%$ desenvolvido no laboratório LabM ${ }^{2}$ com a contribuição significativa de dois alunos de Iniciação Científica, ambos tiveram bolsa FAPESP: Amanda Shiokawa Naxara Freitas - 2009/06313-5 e Eduardo Morato Redoschi 2010/12509-7.

difusão.

Um trabalho foi realizado no $\mathrm{LabM}^{2}$ com o objetivo de analisar os algoritmos usados durante a OMTC, ou difusão, para a aquisição do centro de massa das microesferas e o erro obtido. Foi detectado um erro sistemático dependente de alguns parâmetros de detecção. Esse erro está associado ao algoritmo de detecção das microesferas, que é o mesmo utilizado atualmente em todos os sistemas OMTC. Nesse algoritmo, a posição das esferas é calculada através de seu centro de massa, que é dado por [91,92]:

$$
\bar{x}=\frac{\sum_{i=1}^{N} \sum_{j=1}^{N} x_{i} I(i, j)}{\sum_{i=1}^{N} \sum_{j=1}^{N} I(i, j)},
$$

onde $\bar{x}$ é a coordenada genérica do centro de massa e $I(i, j)$ é a intensidade do pixel que ocupa a posição $(i, j)$ na imagem. Quanto mais próximo do preto, maior o valor de $I(i, j)$. As imagens 

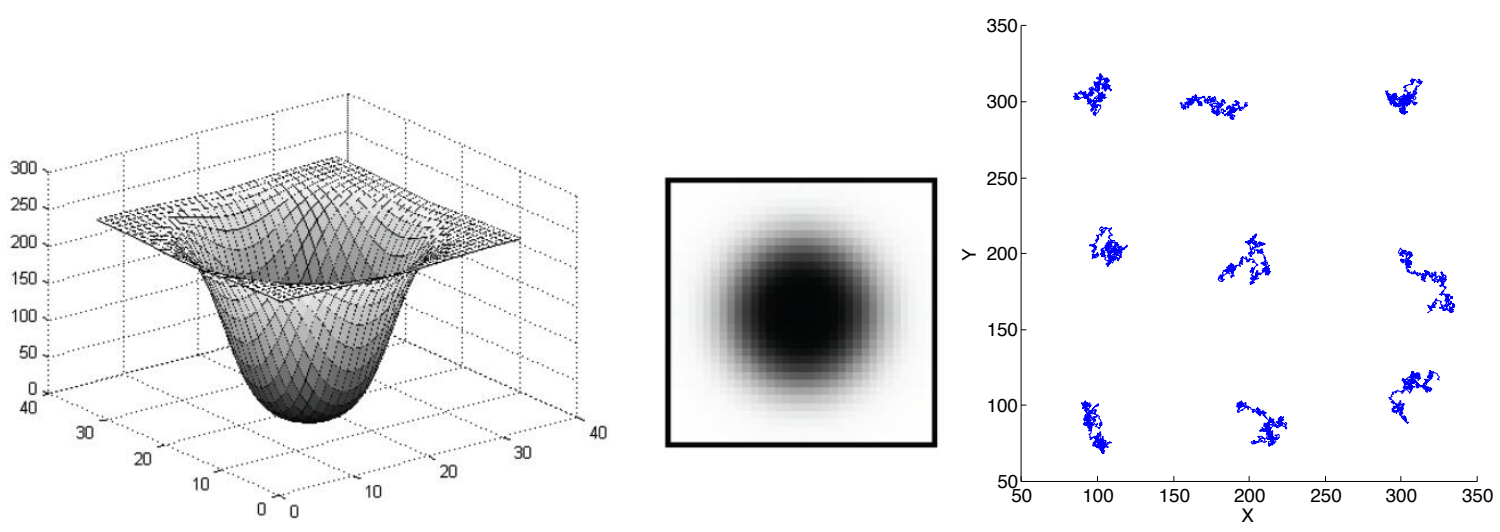

Figura E.0-2. À esquerda é mostrado um gráfico que gerou as esferas, ao centro, uma imagem da esfera gerada após a quantização da "profundidade" do pixel (0-255) e espacial devido a dimensão do pixel em relação ao raio da esfera. À direita a trajetória aleatória prescrita de 9 esferas. Neste caso temos $D=18$, imagem em escala de cinza de 8 bits [91].

das esferas são adquiridas através da câmera integrada ao microscópio, porém possuem um ruído fundo, o qual fundo possui um padrão que interfere no cálculo do centro de massa. Para evitar este erro, usualmente se define um limiar para o qual valores de intensidade menores a ele serão transformados em branco, ou seja, possuirão $I(i, j)$ com valor zero.

Neste trabalho [91,92], a eficiência do algoritmo de rastreamento foi estudada através da geração de imagens similares às obtidas durante o experimento de OMTC ou difusão. Foi utilizado um modelo numérico para gerar imagens computacionais de esferas, representado pela seguinte equação:

$$
I(r, w, D)=\frac{1}{2} \tanh \left(\frac{r}{w} \frac{D}{2 w}\right),
$$

onde $D$ é o diâmetro da esfera relativa ao tamanho em pixels, $r$ é o raio efetivo da esfera, ou seja, o raio da região da esfera utilizada para o cálculo do centro de massa, e $w$ é um parâmetro que indica a distância em pixel que a esfera varia $76 \%$ de sua intensidade. A Fig. E.0-2 mostra um exemplo das esferas geradas. Numericamente fizemos essas esferas seguirem um caminho aleatório com passos de tamanhos inferiores a um pixel para produzir uma sequência de imagens similares às imagens obtidas durante a difusão passiva. 

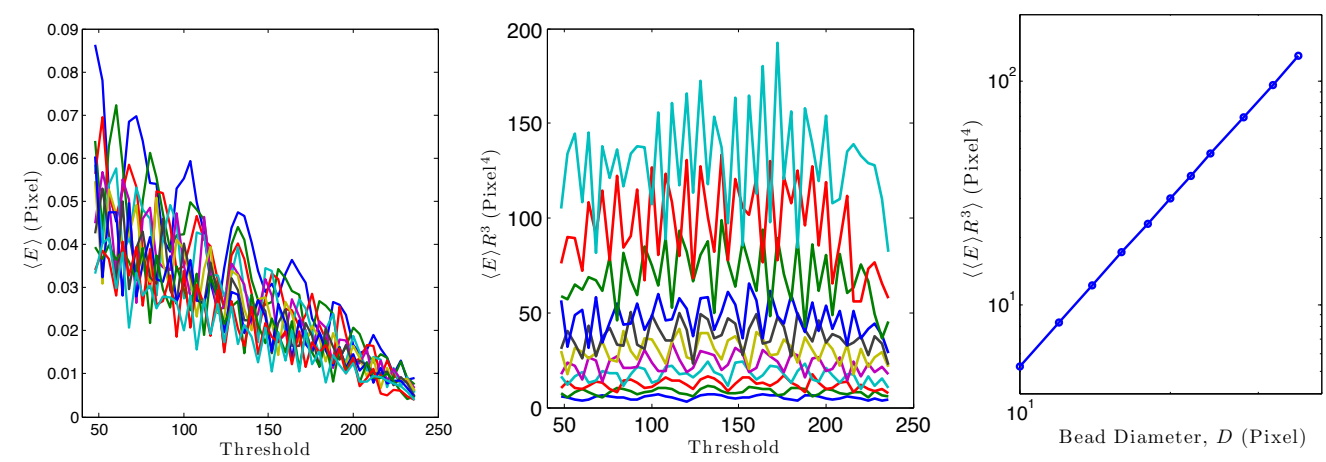

Figura E.0-3. (Esquerda) Cálculo do Erro para cada valor do limiar Th da simulação computacional do modelo simplificado $(T h \times E)$, cada cor representa uma dimensão de esfera. (Centro) multiplicando o Error por $r^{3}$ ou seja $T h \times E r^{3}$ [91]. (Direita) Diâmetro da microesfera $D$ versus o erro médio $\left(D \times\left\langle E r^{3}\right\rangle\right)$ [91].

Essas imagens foram enviadas ao software de OMTC como se fossem imagens do microscópio. Com as imagens e sabendo o caminho prescrito pode-se calcular o erro em relação aos dados gerados pelo caminho aleatório e o software de aquisição do centro de massa, obtendo, assim um erro E, como mostrado na Fig. E.0-3 à esquerda. Para cada limiar, é possível calcular o raio teórico $r$ no qual a esfera foi cortada, então, multiplicando-se o valor do $E$ por este $r$ ao cubo, Fig. E.0-3 ao centro.

Observa-se que para cada $D$ o gráfico é aproximadamente uma constante. A seguir foi analisada a relação do valor desta constante, ou valor médio de cada $E r^{3}$ e $D$. O resultado em um gráfico dilog é apresentado na Fig. E.0-3 à direita. Calculando a função dada pela reta, é encontrado:

$$
E=\frac{10^{a} D^{b}}{r^{3}}
$$

onde $a=0.01679$ e $b=2.49792$.

Pode-se concluir que o erro decresce com o aumento do limiar e também que o erro de detecção é proporcional a $D^{2.5}$ e inversamente proporcional a $r^{3}$. Esse resultado é muito importante na hora de se determinar o erro que se espera ter na hora de um experimento, e diferenciá-lo corretamente dos dados. 


\section{O software da OMTC}

Como as trajetórias das esferas foram prescritas, é possível, então, avaliar o erro de detecção sobre várias condições diferentes, como o efeito do diâmetro da esfera relativo ao tamanho em pixels, o efeito da detecção do limiar e a presença do ruído de fundo. Além de ser uma importante ferramenta de análise estatística, pois o mesmo que foi feito com caminho aleatório, pode ser feito para prescrever outros tipos de movimento e comparar com oque será medido na OMTC ou difusão. 
O software da OMTC 


\section{Apêndice F}

\section{Microesferas}

As microesferas utilizadas neste trabalho são de látex e ferrimagnéticas.

Microesferas de látex: foram compradas na Invitrogen Molecular Probes e suas características estão descritas na Tabela F.1.

\begin{tabular}{cc}
\hline Características & Informação \\
\hline Tipo & Látex branca não iônica \\
Número de Catálogo & $\mathrm{N} 37453$ \\
Número Mat. Lot. & 1244,2 \\
Número Packing Lot. & 1035803 \\
Packaging Date & 31 de Agosto de 2011 \\
Diâmetro $(\mu \mathrm{m})$ & 2.4 \\
Desvio Padrão $(\mu \mathrm{m})$ & 0.029 \\
Sólido \% $(\mathrm{w} / \mathrm{v})$ & $1.2 \%$ \\
Volume $(\mathrm{m} \ell)$ & 4.0 \\
Coeficiente de Variação do Diâmetro & 15 \\
Número de Partículas por milímetro de látex & $5.3 \cdot 10^{9}$ \\
Área de Superfície $\left(\mathrm{cm}^{2} / \mathrm{g}\right)$ & $2.4 \cdot 10^{4}$ \\
Armazenamento & 2 a $8^{\circ} \mathrm{C}$, não congelar \\
\hline \hline
\end{tabular}

Tabela F.1. Características das microesferas de látex. 
Microesferas

\begin{tabular}{cc}
\hline Características & Informações \\
\hline Constante $(\mathrm{Pa} / \mathrm{Gauss})$ & 1.7242 \\
Diâmetro $(\mu \mathrm{m})$ & 4.1 \\
Desvio padrão $(\mu \mathrm{m})$ & 0.42 \\
$\%$ & 0.102 \\
Beads/m $\ell$ & $3.32 \cdot 10^{7}$ \\
Volume de uma unidade de bead $\left(\mu \mathrm{m}^{3}\right)$ & $3.61 \cdot 10$ \\
Massa de uma unidade de bead $(\mathrm{mg})$ & $1.8 \cdot 10^{-7}$ \\
$\mathrm{mg} / \mathrm{m} \ell$ & 5.99 \\
área $\left(\mu \mathrm{m}^{2}\right) / \mathrm{m} \ell$ & $1.75 \cdot 10^{9}$ \\
$\mathrm{~m} \ell$ & 2.7 \\
$\mathrm{mg}$ & 16.17 \\
$\mu \ell / \mathrm{mg}$ & 166.95 \\
\hline \hline
\end{tabular}

Tabela F.2. Características das microesferas ferrimagnéticas.

Microesferas ferrimagnéticas: foram compradas em Harvard School of Public Health, e suas características estão descritas na Tabela F.2. 


\section{Apêndice G}

\section{Calibração das Câmeras}

As câmeras foram calibradas em relação $\mu \mathrm{m} /$ pixel. A calibração para a câmera Pike AVT está mostrada na Tab. G.1, e a calibração da câmera Andor Neo sCMOS está mostrada na Tab. G.2.

\begin{tabular}{cc}
\hline Objetiva & $\mu \mathrm{m} /$ pixel \\
\hline $10 \times$ & 0.727 \\
$20 \times$ & 0.324 \\
$40 \times$ & 0.180 \\
\hline \hline
\end{tabular}

Tabela G.1. Tabela com os valores de calibração $\mu \mathrm{m} /$ pixel para a câmera Pike AVT.

\begin{tabular}{cc}
\hline Objetiva & $\mu \mathrm{m} /$ pixel \\
\hline $10 \times$ & 0.648 \\
$20 \times$ & 0.324 \\
$40 \times$ & 0.162 \\
$63 \times$ & 0.103 \\
\hline \hline
\end{tabular}

Tabela G.2. Tabela com os valores de calibração $\mu \mathrm{m} /$ pixel para a câmera Andor Neo sCMOS. 
Calibração das Câmeras 


\section{Apêndice H}

\section{Método de Euler-Maruyama para Equações Diferenciais Estocásticas}

Este apêndice foi baseado no artigo de D. J. Higham [93] sobre simulações numéricas de equações diferenciais estocásticas (EDEs), usadas no Cap. 7. Considere a EDE de Itô:

$$
\left\{\begin{array}{l}
d X(t)=f(X(t)) d t+g(X(t)) d W(t) \\
X(0)=X_{0} \\
0 \leq t \leq T
\end{array}\right.
$$

onde $f$ e $g$ são funções escalares, $X_{0}$ é a condição inicial e $d W(t)$ é uma variável aleatória independente. Se $g \equiv 0$ e $X_{0}$ uma constante, a Eq. H.1 se torna determinística, se reduzindo a uma equação diferencial ordinária (EDO) $d X(t) / d t=f(X(t)), \operatorname{com} X(0)=X_{0}$.

Para aplicar-se métodos numéricos à Eq. H.1, primeiramente discretiza-se o intervalo $[0, T]$. Assim, $\Delta t=T / L$ para um $L$ inteiro e positivo, e $t_{i}=i \Delta t$. Aqui, $X\left(t_{i}\right)=X_{i}$. Dessa maneira, 


\section{Método de Euler-Maruyama para Equações Diferenciais Estocásticas}

o método de Euler-Maruyama (EM) é dado por:

$$
X_{i}=X_{i-1}+f\left(X_{i-1}\right) \Delta t+g\left(X_{i-1}\right)\left(W\left(t_{i}\right)-W\left(t_{i-1}\right)\right),
$$

$\operatorname{com} i=1,2, \ldots, L$. 


\section{Apêndice I}

\section{Atividades Acadêmicas}

\section{$\underline{\text { Resumos e Apresentações em Congressos }}$}

- XXXIV Encontro de Física da Matéria Condensada, 5 a 10 de Junho de 2011, Foz de Iguaçu. Com apresentação do pôster Anomalous Diffusion of Microbeads in Live Cells: the Probability of Rare Events.

- Perspectives and Challenges in Statistical Physics and Complex Systems for the Next Decade: A Conference in Honor of Eugene Stanley and Liacir Lucena, 9 a 11 de Novembro de 2011, Natal, RN. Com apresentação do pôster Anomalous Diffusion of Microspheres in the Calculation of Viscoelasticity and Reorganization of Cytoskeleton.

- Workshop on Complex Systems: Social and Biological Applications, 5 a 9 de Dezembro de 2011, Instituto de Física da USP. Com apresentação oral Rheological Properties of Complex Fluids by Microbeads Tracking.

- XXXV Encontro Nacional de Física da Matéria Condensada, 14 a 18 de Maio de 2012, Águas de Lindóia. Com apresentação do pôster Rheological Properties of Lung Surfac- 
tants by Particle Tracking.

- Alencar, A. M. ; Redoshi, E. M. ; Ferraz, M. S. A.. Finding the Viscoelastic Modulus by Tracking the Spontaneous Diffusion of Microbeads in Live Cells. In: International Conference of American Thoracic Society ATS, 18 a 23 de Maio de 2012.

- Ferreira, M. Z. J.; Nishitani, W. S.; Ferraz, M. S. A.; Dorta, M. P; Figueroa, H. E. H.; Alencar, A. M.. Anomalous Diffusion Evidenced by Particle Tracking at High Frame Rates. In: XXXVI Encontro Nacional de Física da Matéria Condensada, 13 a 17 de Maio de 2013, Águas de Lindóia.

- Ferraz, M. S. A.; Alencar, A. M.. Model for Dynamic of the Cytoskeleton. In: XXXVI Encontro Nacional de Física da Matéria Condensada, 13 a 17 de Maio de 2013, Águas de Lindóia.

- Ferreira, M. Z. J.; Ferraz, M. S. A.; Figueroa, H. E. H.; Cavalcante, F. S. A.; Evangelista, J. S. A. M.; Alencar, A. M.. Rheological Properties of Smooth Muscle Cells Exposed to Crotalus Durissus Cascavella Snake Venom. In: American Thoracic Society International Conference - ATS, 16 a 21 de Maio de 2014, San Diego.

- Ferreira, M. Z. J.; Oliveira Neto, J.; Evangelista, J. S. A. M.; Cavalcante, F. S. A.; Ferraz, M. S. A.; Alencar, A. M.. Viscoelastic Properties Of Cells Exposed to Crotalus Durissus Cascavella Snake Venom. In: XXXVII Encontro Nacional de Física da Matéria Condensada, 12 a 16 de Maio de 2014, Costa do Sauípe.

- XXXVII Encontro Nacional de Física da Matéria Condensada, 12 a 16 de Maio de 2014, Costa do Sauípe. Com a apresentação do pôster: Anomalous Diffusion of Cytoskeleton of Smooth Muscle Cells at High Frame Rates, autores: Ferraz, M. S. A.; Ferreira, M. Z. J.; Alencar, A. M.. 


\section{Atividades Acadêmicas}

- Menegon, M. O.; Ferraz, M. S. A.; Alencar, A. M.. Microrheology of polymer networks. In: XXXVII Encontro Nacional de Física da Matéria Condensada, 12 a 16 de Maio de 2014, Costa do Sauípe.

- 1st Symposium on Current Topics in Molecular Biophysics, 21 a 23 de Maio de 2014, São Paulo. Com a apresentação do pôster: Time Series Analyses of the Remodeling of the Cytoskeleton, autores: Ferraz, M. S. A.; Alencar, A. M..

- Almeida, M. E.; Pennachi, P. C.; Ferraz, M. S. A.; Maria-Engler, S. S.; Alencar, A. M.; Santos, M. F.. Glycated Collagen Affects Dermal Fibroblasts Proliferation, Adhesion, Migration and Cytoskeletal Physical Properties in Normoglycemic and Hyperglycemic Rats In: XVII Meeting of the Brazilian Society for Cell Biology, 2014, Foz do Iguaçu. XVII Meeting of the Brazilian Society for Cell Biology, 2014.

- Ferraz, M. S. A.; Bassaneze, V.; Krieger, J. E.; Alencar, A. M.. Traction Force Microscopy (TFM) Applied to Cardiomyocytes: submetido para o XXXVIII Encontro Nacional de Física da Matéria Condensada.

- Aoki, F. G.; Ferraz, M. S. A.; Nishitani, W. S.; Alencar, A. M.. Effect of Methacholine in Smooth Muscle Cells Using Traction Force Microscopy: submetido para o XXXVIII Encontro Nacional de Física da Matéria Condensada.

- Menegon, M.; Ferraz, M. S. A.; Alencar, A. M.. Comparative study of the passive and active microrheology using collagen gels:submetido para o XXXVIII Encontro Nacional de Física da Matéria Condensada.

- Schianti, J. N.; Gongora-Rúbio, M. R.; Ferraz, M. S. A.; Cervantes, J. E. R; Alencar, A. M.. Biomechanical responses of vascular cells evaluated by Traction Force Microscopy (TFM) under continuous shear stress applied by the use of Microfluidic Devices: submetido para o XXXVIII Encontro Nacional de Física da Matéria Condensada. 


\section{Artigos}

- Ferraz, M. S. A. and Alencar, A. M.; Measurement of Local Forces and Viscoelasticity in Living Cells, In: $17^{a}$ Convención Científica de Ingeniería y Architectura, Cuba, 2014.

- Alencar, A. M., Ferraz, M. S. A., Park, C. Y., Millet, E., Butler, J. P. and Fredberg, J. J., Trepat, X.; Cytoquake Dynamics: Remodeling and Stabilization of the Cytoskeleton: submetido para PRL.

\section{Estágio Sanduíche}

No período de Setembro de 2012 até Maio de 2013 a aluna fez um estágio sanduíche no grupo do professor Jeffrey Joseph Fredberg do Laboratory for Molecular and Integrative Cellular Dynamics [34] em Harvard School of Public Health em Boston. O grupo do Prof. Fredberg é muito forte e reconhecido no meio acadêmico em pesquisas relacionadas a dinâmica celular, CSK e migração.

Neste período, a aluna participou das atividades do grupo, dentre elas, reuniões e técnicas experimentais. O projeto principal desenvolvido lá está descrito ns Seção 8.2. A aluna dará continuidade ao projeto aqui na USP, mantendo contato com pesquisadores de lá. Outro projeto, fruto também dos contatos feitos, está descrito na Seção 8.1. 


\section{Referências Bibliográficas}

[1] M. R. K. Mofrad, "Rheology of the cytoskeleton," Annu. Rev. Fluid Mech., vol. 41, pp. 433-53, 2009.

[2] R. D. Kamm and M. R. K. Mofrad, Introduction, with the biological basis for cell mechanics, IN BOOK: Cytoskeletal Mechanics, Models and Measurements, Ed. R. D. Kamm and M. R. K. Mofrad, pp. 1-17. New York: Cambridge University Press, 2006.

[3] B. Alberts, D. Bray, A. Johnson, J. Lewis, M. Raff, K. Roberts, and P. Walter, Fundamentos da Biologia Celular, uma Introdução à Biologia Molecular da Célula. Porto Alegre: Ed. Artes Médicas Sul Ltda., 1999.

[4] C. Verdier, J. Etienne, A. Duperray, and L. Preziosi, "Review. rheological properties of biological materials," Comptes Rendus Physique, vol. 10, pp. 790-811, 2009.

[5] J. J. Fredberg, "Airway smooth muscle in asthma: flirting with disaster," Eur Respir J, vol. 12 , no. 6, pp. 1252-6, 1998.

[6] M. N. Oliver, B. Fabry, A. Marinkovic, S. M. Mijailovich, J. P. Butler, and J. J. Fredberg, "Airway hyperresponsiveness, remodeling, and smooth muscle mass: right answer, wrong reason?," Am J Respir Cell Mol Biol, vol. 37, no. 3, pp. 264-72, 2007. 


\section{REFERÊNCIAS BIBLIOGRÁFICAS}

[7] P. Bursac, G. Lenormand, B. Fabry, M. Oliver, D. Weitz, V. Viasnoff, J. Butler, and J. Fredberg, "Cytoskeletal remodelling and slow dynamics in the living cell," Nature, vol. 4, pp. 557-561, 2005.

[8] S. R. A. Salinas, Introdução à física estatística. São Paulo: Editora da Universidade de São Paulo - Edusp, 2005.

[9] J. M. Silva and J. A. S. Lima, "Quatro abordagens para o movimento browniano," Revista Brasileira de Ensino de Física, vol. 29, no. 1, pp. 25-35, 2007.

[10] M. Sadati, N. T. Qazvini, R. Krishnan, C. Y. Park, and J. J. Fredberg, "Collective migration and cell jamming," Differentiation, 2013.

[11] M. Sadati, A. Nourhani, J. J. Fredberg, and N. T. Qazvini, "Glass-like dynamics in the cell and in cellular collectives," WIREs Syst Biol Med, 2014.

[12] R. L. Steward Jr., S. R. Rosner, E. Zhou, and J. J. Fredberg, "Illuminating human health through cell mechanics," Swiss Med Wkly, vol. 143, 2013.

[13] R. A. L.Jones, Soft Condensed Matter. New York: Oxford University Press, 2002.

[14] S. R. A. Salinas, "Einstein e a teoria do movimento browniano," Revista Brasileira de Ensino de Física, vol. 27, no. 2, pp. 263-269, 2005.

[15] P. Oswald, Rheophysics: the Deformation and Flow of Matter. Cambridge: Cambridge University Press, 2009.

[16] R. G. Larson, The structure and rheology of complex fluids. New York: Oxford University Press, 1998.

[17] M. L. Rodriguez, P. J. McGarry, and N. J. Sniadecki, "Review on cell mechanics: experimental and modeling approaches," Transactions of the ASME, vol. 65, p. 060801, 2013. 


\section{REFERÊNCIAS BIBLIOGRÁFICAS}

[18] G. Lenormand, A. M. Alencar, X. Trepat, E. Zhou, B. Fabry, J. Butler, and J. J. Fredberg, The cytoskeleton of the living cell as an out-of-equilibrium system, IN BOOK: Phase Transitions in Cell Biology, Ed. G. H. Pollack and W.-C. Chin, pp. 113-143. New York: Springer, 2008.

[19] B. Fabry, G. Maksym, J. Butler, M. Glogauer, D. Navajas, and J. Fredberg, "Scaling the microrheology of living cells," Phys. Rev. Lett., vol. 87, no. 14, p. 148102, 2001.

[20] G. Lenormand and J. Fredberg, "Deformability, dynamics, and remodeling of cytoskeleton of the adherent living cell," Biorheology, vol. 43, no. 1, pp. 1-30, 2006.

[21] H. T. Moriya, D. J. Colen, G. N. Maksym, and A. M. Alencar, "Citometria ópticomagnética de rotação: exemplo de um método para medir as propriedades reológicas da célula," $21^{\circ}$ Congresso Brasileiro de Engenharia Biomédica, pp. 1234-1237, 2008.

[22] T. G. Mason and D. A. Weitz, "Optical measurements of frequency-dependent linear viscoelastic moduli of complex fluids," Physical Review Letters, vol. 74, no. 7, pp. 1250$1253,1995$.

[23] T. M. Squires and T. G. Mason, "Fluid mechanics of microrheology," Annu. Rev. Fluid Mech., vol. 42, pp. 413-438, 2009.

[24] J. J. Fredberg and B. Fabry, The cytoskeleton as a soft glassy material, IN BOOK: Cytoskeletal Mechanics Models and Measurements, Ed. M. R. K. Mofrad and R. D. Kamm, pp. 50-70. New York: Cambridge, 2006.

[25] P. Sollich, "Rheological constitutive equation for a model of soft glassy materials," Phys. Rev. E, vol. 58, pp. 738-759, 1998.

[26] J. P. Bouchaud, "Weak ergodicity breaking and aging in disordered systems," J. Phys. I France, vol. 2, pp. 1705-1713, 1992. 


\section{REFERÊNCIAS BIBLIOGRÁFICAS}

[27] B. Fabry and J. J. Fredberg, "Remodeling of the airway smooth muscle cell: are we built of glass?," Respiratory Physiology \& Neurobiology, vol. 137, pp. 109-124, 2003.

[28] X. Trepat and J. J. Fredberg, "Plithotaxis and emergent dynamics in collective cellular migration," Trends in Cell Biology, 2011.

[29] E. Angelini, T. E. Hannezo, X. Trepat, M. Marquez, J. J. Fredberg, and D. A. Weitz, "Glass-like dynamics of collective cell migration," PNAS, 2011.

[30] X. Trepat, M. R. Wasserman, T. E. Angelini, E. Millet, D. A. Weitz, J. P. Butler, and J. J. Fredberg, "Physical forces during collective cell migration," Nature Physics, vol. 5, 2009.

[31] D. T. Tambe, C. C. Hardin, T. E. Angelini, K. Rajendran, C. Y. Park, X. Serra-Picamal, E. H. Zhou, M. H. Zaman, J. P. Butler, D. A. Weitz, J. J. Fredberg, and X. Trepat, "Collective cell guidance by cooperative intercellular forces," Nature Materials, vol. 10, 2011.

[32] G. T. Eisenhoffer, P. D. Loftus, M. Yoshigi, H. Otsuna, C. B. Chien, P. A. Morcos, and J. Rosenblatt, "Crowding induces live cell extrusion to maintain homeostatic cell numbers in epithelia," Nature Letter, 2012.

[33] E. Marinari, M. A., S. Curran, J. Gale, D. T., and B. Baum, "Live-cell delamination counterbalances epithelial growth to limit tissue overcrowding," Nature Letter, 2012.

[34] "Laboratory for molecular and integrative cellular dynamics - havard school of public health http://www.hsph.harvard.edu/fredberglab/index.html."

[35] X. Trepat, L. Deng, S. S. An, D. Navajas, D. J. Tschumperlin, W. T. Gerthoffer, J. P. Butler, and J. J. Fredberg, "Universal physical responses to stretch in the living cell," Nature, vol. 447, pp. 592-595, 2007. http://dx.doi.org/10.1038/nature05824. 


\section{REFERÊNCIAS BIBLIOGRÁFICAS}

[36] P. Bursac, B. Fabry, X. Trepat, G. Lenormand, J. P. Butler, N. Wang, J. J. Fredberg, and S. S. An, "Cytoskeleton dynamics: Fluctuations within the network," Biochemical and Biophysical Research Communications, vol. 355, pp. 324-330, 2007.

[37] G. Lenormand, J. Chopin, P. Bursac, J. J. Fredberg, and J. P. Butler, "Linearity and timescale invariance of the creep function in living cells," J. Roy. Soc. Interf., vol. 1, pp. 91-97, 2004.

[38] L. Deng, X. Trepat, J. P. Butler, E. Millet, K. G. Morgan, D. A. Weitz, and J. J. Fredberg, "Fast and slow dynamics of the cytoskeleton," Nature, vol. 5, no. 8, pp. 636-640, 2006.

[39] N. Q. Balaban, U. S. Schwarz, D. Riveline, P. Goichberg, G. Tzur, S. I., D. Mahalu, S. Safran, A. Bershadsky, L. Addadi, and B. Geiger, "Force ando focal adhesion assembly: a close relationship studied using elastic micropatterned substrates," Nature Cell Biology, vol. 3, pp. 466-472, 2001.

[40] J. Howard, Mechanics of Motor Proteins and the Cytoskeleton. Massachusetts: Sinauer Associates, 2001.

[41] N. Rosenblatt, A. M. Alencar, A. Majumdar, B. Suki, and D. Stamenović, "Dynamics of prestressed semiflexible polymer chains as a model of cell rheology," Phys. Rev. Lett., vol. 97 , no. 16, p. 168101, 2006.

[42] A. Ansari, J. Berendzen, S. F. Bowne, H. Frauenfelder, I. E. T. Iben, T. B. Sauke, E. Shyamsunder, and R. D. Young, "Protein states and proteinquakes," Biophysics, vol. 82, pp. 5000-5004, 1985.

[43] H. Frauenfelder, S. Sligar, and P. Wolynes, "The energy landscapes and motions of proteins," Science, vol. 254, no. 5038, pp. 1598-1603, 1991.

[44] J. Langer, “The mysterious glass transition,” Physics Today, vol. 60, no. 2, pp. 8-9, 2007. 


\section{REFERÊNCIAS BIBLIOGRÁFICAS}

[45] G. Biroli, "Jamming: A new kind of phase transition?," Nat. Phys., vol. 3, no. 4, pp. 222-3, 2007.

[46] A. S. Keys, A. R. Abate, S. C. Glotzer, and D. J. Durian, "Measurement of growing dynamical length scales and prediction of the jamming transition in a granular material," Nat. Phys., vol. 3, no. 4, pp. 260-4, 2007.

[47] J. Brujic, K. A. Hermans Z., Rodolfo I.and Walther, and J. M. Fernandez, "Singlemolecule force spectroscopy reveals signatures of glassy dynamics in the energy landscape of ubiquitin," Nat. Phys., vol. 2, pp. 282-6, 2006.

[48] S. Hu, J. Chen, B. Fabry, Y. Numaguchi, A. Gouldstone, D. E. Ingber, J. J. Fredberg, J. P. Butler, and N. Wang, "Intracellular stress tomography reveals stress focusing and structural anisotropy in cytoskeleton of living cells," American Journal of Physiology Cell Physiology, vol. 285, no. 5, pp. C1082-C1090, 2003.

[49] G. Ouillon, C. Castaing, and D. Sornette, "Hierarchical geometry of faulting," Journal of Geophysical Research-Solid Earth, vol. 101, pp. 5477-5487, 1996.

[50] C. Y. Park, D. Tambe, A. M. Alencar, X. Trepat, E. Zhou, E. Millet, J. P. Butler, and J. J. Fredberg, "Mapping the cytoskeletal prestress," Am. J. Physiol. Cell Physiol., vol. 298, pp. C1245-C1252, 2010.

[51] J. Glass, J. Blevitt, K. Dickerson, M. D. Pierschbacher, and W. S. Craig, "Cell attachment and motility on materials modified by surface-active rgd-containing peptides," Annals of the New York Academy of Sciences, vol. 745, no. 1, pp. 177-186, 1994.

[52] W. S. Craig, S. Cheng, D. G. Mullen, J. Blevitt, and M. D. Pierschbacher, "Concept and progress in the development of rgd-containing peptide pharmaceuticals," Biopolymers, vol. 37, no. 2, pp. 157-75, 1995. 


\section{REFERÊNCIAS BIBLIOGRÁFICAS}

[53] D. Mizuno, C. Tardin, C. F. Schmidt, and F. C. Mackintosh, "Nonequilibrium mechanics of active cytoskeletal networks," Science, vol. 315, pp. 370-3, 2007.

[54] B. Stuhrmann, E. S. M. Soares, M. Depken, F. C. Mackintosh, and G. H. Koenderink, "Nonequilibrium fluctuations of a remodeling in vitro cytoskeleton," Phys. Rev. E, vol. 86, p. 020901, 2012.

[55] F. Lillo and R. N. Mantegna, "Power-law relaxation in a complex system: Omori law after a financial market crash," Phys. Rev. E, vol. 68, p. 016119, 2003.

[56] S. Zapperi, A. Vespignani, and H. E. Stanley, "Plasticity and avalanche behaviour in microfracturing phenomena," Nature, vol. 388, pp. 658-660, 1997.

[57] S. Abe and N. Suzuki, "Omori's law in the internet traffic," Europhysics Letters, vol. 61, pp. 852-855, 2003.

[58] T. Leonard, O. Papasouliotis, and I. G. Main, "A poisson model for identifyind characteristic size effects in frequency data: Application to frequency-size distributions for global earthquakes, 'starquakes', and fault lenghts," Journal of Geophysical Research, vol. 106, no. B7, pp. 473-13, 2001.

[59] J. Greenhough and I. . Main, "A poisson model for earthquake frequency uncertainties in seismic hazard analysis," Geophysical Research Letters, vol. 35, no. 19, 2008.

[60] R. N. Mantegna and H. E. Stanley, An Introduction to Econophysics. Correlations and Complexity in Finance. Cambridge, United Kingdom: Cambridge University Press, 1999.

[61] G. M. Viswanathan, M. G. E. da Luz, E. P. Raposo, and H. E. Stanley, The Physics of Foraging. An Introduction to Random Searches and Biological Encounters. Cambridge, United Kingdom: Cambridge University Press, 2011. 


\section{REFERÊNCIAS BIBLIOGRÁFICAS}

[62] G. M. Viswanathan, V. Afanasyev, S. V. Buldyrev, E. J. Murphy, P. A. Prince, and S. H. E., "Lévy flight search patterns of wandering albatrosses," Nature, vol. 381, pp. 413-415, 1996.

[63] “Toolbox de estatística do matlab http://www.mathworks.com/help/stats/ index.html."

[64] "Stbl: Alpha stable distributions for matlab http:// wWw. mathworks.com/matlabcentral/fileexchange/

37514-stbl--alpha-stable-distributions-for-matlab."

[65] " $\mu$ manager https: / / www.micro-manager.org."

[66] "Imagej https://imagej.nih.gov/ij/."

[67] D. Weihs, M. A. Teitell, and T. G. Mason, "Simulations of complex particle transport in heterogeneous active liquids," Microfluid Nanofluid, 2006.

[68] M. T. Valentine, P. D. Kaplan, D. Thota, J. C. Crocker, T. Gisler, R. K. Prud'homme, M. Beck, and D. A. Weitz, "Investigating the microenvironments of inhomogeneous soft materials with multiple particle tracking," Physical Review E, vol. 64, p. 061506, 2001.

[69] S. Deguchi, T. Ohashi, and M. Sato, "Tensile properties of single stress fibers isolated from cultured vascular smooth muscle cells," Journal of Biomechanics, vol. 39, pp. 2603-2610, 2006.

[70] D. L. Turcotte, "Self-organized criticality," Rep. Prog. Phys., vol. 62, pp. 1377-1429, 1999.

[71] P. S. Grassia, E. J. Hinch, and L. C. Nitsche, "Computer simulations of brownian motion of complex systems," J. Fluid. Mech., vol. 282, pp. 373-403, 1995. 


\section{REFERÊNCIAS BIBLIOGRÁFICAS}

[72] A. Caspi, R. Granek, and M. Elbaum, "Diffusion and directed motion in cellular transport," Physical Review E, vol. 66, p. 011916, 2002.

[73] V. S. Deshpande, M. Mrksich, R. M. McMeeking, and A. G. Evans, "A bio-mechanical model for coupling cell contractility with focal adhesion formation," Journal of the Mechanics and Physics of Solids, vol. 56, pp. 1484-1510, 2008.

[74] Y.-C. Poh, S. Na, F. Chowdhury, M. Ouyang, Y. Wang, and N. Wang, "Rapid activation of rac gtpase in living cells by force is independent of src," PLoS ONE, vol. 4, no. 11, p. e7886, 2009.

[75] T. Zhao, Y. Li, and A. R. Dinner, "How focal adhesion size depends on integrin affinity," Langmuir, vol. 25, pp. 1540-1546, 2009.

[76] L. Y. Koo, D. J. Irvine, M. A. M., D. A. Lauffenburger, and L. G. Griffith, "Co-regulation of cell adhesion by nanoscale rgd organization and mechanical stimulus," Journal of Cell Science, vol. 115, pp. 1423-1433, 2002.

[77] J. Huang and D. L. Turcotte, "Evidence for chaotic fault interactions in the seismicity of the san andreas fault and nankai trough," Letters to Nature, vol. 348, 1990.

[78] N. J. Serves, “The cardiac muscle cell,” BioEssays, vol. 22, pp. 188-199, 2000.

[79] D. Tirziu, F. J. Giordano, and M. Simons, "Cell communications in the heart," Circulation, vol. 122, pp. 928-937, 2010.

[80] E. J. D. Souza, W. Ahmed, R. Bashir, and T. Saif, "Cardiac myocites' dynamic contractile behaviour differs depending on heart segment," Biotechnology and Bioengineering, 2012.

[81] E. Ehler and P. J.-C., "Cardiomyocyte cytoskeleton and myofibrillogenesis in healthy and diseased heart," Heart Failure Reviews, vol. 5, no. 3, 2000. 


\section{REFERÊNCIAS BIBLIOGRÁFICAS}

[82] T. Tanaka, S. Tohyama, M. Murata, F. Noruma, T. Kaneko, H. Chen, F. Hattori, T. Egashira, T. Seki, Y. Ohno, U. Koshimizu, S. Yuasa, S. Ogawa, S. Yamanaka, K. Yasuda, and K. Fukuda, "In vitro pharmacologic testing using human induced pluripotent stem cell-derived cardiomyocytes," Biochemical and Biophysical Research Communications, vol. 385, no. 4, pp. 497-502, 2009.

[83] M. Dembo and Y. L. Wang, "Stresses at the cell-to-substrate interface during locomotion of fibroblasts," Biophys J, vol. 76, no. 4, pp. 2307-16, 1999.

[84] J. P. Butler, I. M. Tolic-Norrelykke, B. Fabry, and J. J. Fredberg, "Traction fields, moments, and strain energy that cells exert on their surroundings," Am J Physiol Cell Physiol, vol. 282, no. 3, pp. C595-605, 2002.

[85] N. J. Sniadecki and C. S. Chen, "Microfabricated silicone elastomeric post arrays for measuring traction forces of adherent cells," Methods Cell Biol, vol. 83, pp. 313-28, 2007.

[86] V. Maruthamuthu, B. Sabass, U. S. Schwarz, and M. L. Gardel, "Cell-ecm traction force modulates endogenous tension at cell-cell contacts," Proc Natl Acad Sci U S A, vol. 108, no. 12 , pp. 4708-13, 2011.

[87] "Pesquisador colaborador chan young park http: / / http: / /www . hsph. harvard. edu/chan-young-park/."

[88] A. Quaglino, M. Salierno, J. Pellegrotti, N. Rubinstein, and E. C. Kordon, "Mechanical strain induces involution-associated events in mammary epithelial cells," BMC Cell Biology, vol. 10, 2009.

[89] T. Tomé and M. J. Oliveira, Dinâmica Estocástica e Irreversibilidade. São Paulo: Editora da Universidade de São Paulo - Edusp, 2001. 


\section{REFERÊNCIAS BIBLIOGRÁFICAS}

[90] T. G. Mason, "Estimating the viscoelastic moduli of complex fluids using the generalized stokes-einstein equation," Rheol Acta, vol. 39, pp. 371-378, 2000.

[91] A. S. N. Freitas, "Escala microscópica - omtc," Relatório de Iniciação Científica, FAPESP, Processo número: 2009/06313-5, 2009.

[92] A. S. N. Freitas, A. Majumdar, and A. M. Alencar, "Simulation of bead dynamics in optical twisting microscopy: Evaluating errors and jumps as artifacts of tracking algorithms," in Proceedings of the Annual Meeting of the American Thoracic Society, 2009.

[93] D. J. Higham, "An algorithmic introduction to numerical simulation of stochastic differential equations," SIAM Review, vol. 43, no. 3, pp. 525-546, 2001. 